



THE ADVANCE OF OUR WEST AFRICAN EMPIRE 


\section{SOME IMPORTANT NEW BOOKS.}

BIG GAME SHOOTING AND TRAVEL IN SOUTH AND EAST AFRICA.

By Fredetrick R. H. Findlay. Medium Si'o, Cloth. Futly Illutsliatect. 2Is, not.

\section{SAND-BURIED RUINS OF KHOTAN.}

By M. AURed StEIx, Indian Ellucational Serice. IVith oicr 120 Illastrations and a Pholograzure Fronlispice and large Map. Medium Sio, Cloth, 2Is. net.

\section{CRIMEAN SIMPSON'S AUTOBIOGRAPHY.}

Editcd by GEORGE EYRE-TODD. W'ilh Illustrations. Rotal Sio, Cloth, 2 Is. net.

Also a fine edition, limited to roo copies, printed on Arnold's anbleachal, hand-made paper, will plales on Fapan paper, £2 2 s. net.

LONDON : T. FISHER UNIVIN. 



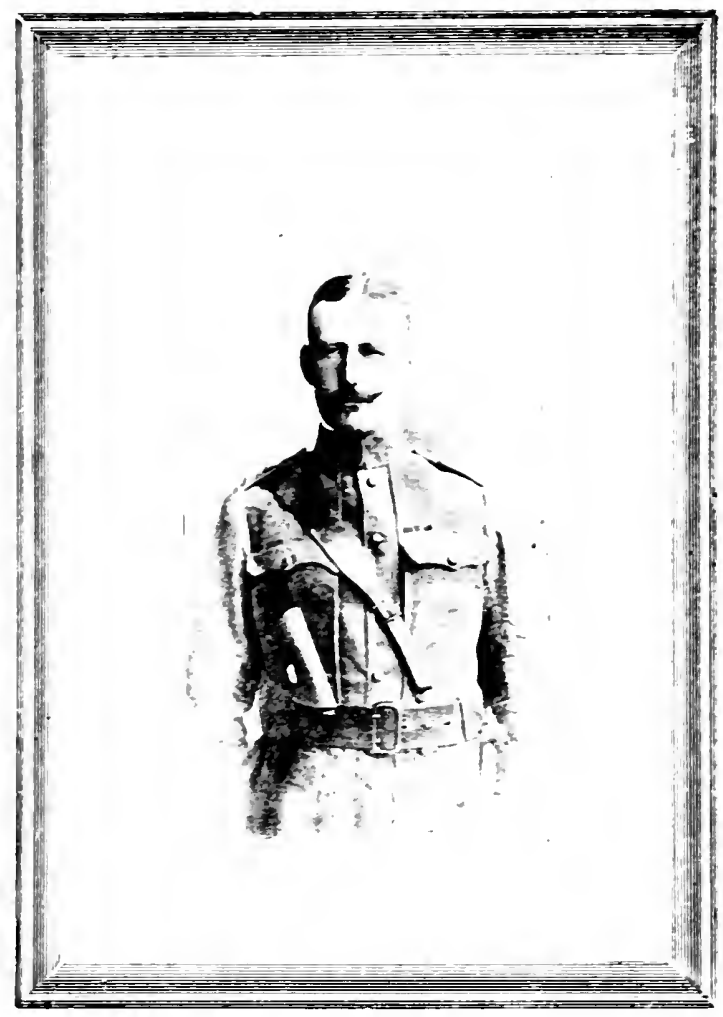

$$
\begin{aligned}
& \text { Yous sureasly } \\
& \text { Bractionteh Als: }
\end{aligned}
$$




\section{THE ADVANCE OF OUR WEST AFRICAN EMPIRE}

เบ

C. BRAITHWAITE WALLIS, F.G.S., F.R.G.S.

(Fellow of the Royat Colonial Instituti, Ec.)

OF

THE CAMERONIANS (SCOTTISH RIFLES)

LATE AGTING DISTRICT COMMISSIONER

SIERRA LEONE PROTECTORATE ++

WITH ILLUSTRATIONS AND A MAP

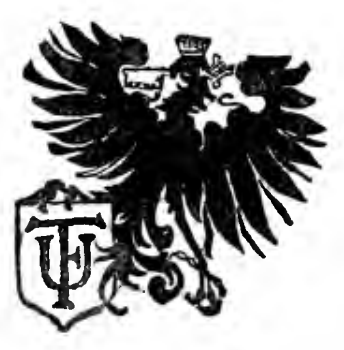

LONDON : T. FISHER UNWIN

PATERNOSTER SQUARE • 1903 
All rishts reserved.] 


\section{To}

Field- Marshal the Right Honourable VISCOUNT WOLSELEY, K.P., G.C.B., O.M., G.C.M.G.,

A GREAT SOLDIER AND A MAN, THE EARLY PART OF WHOSE BRILLIANT CAREER WAS SPENT IN THE REGIMENT TO WHICH HAVE THE hoNouR TO BELONG, WhOSE GENIUS, LOVE OF COUNTRY, AND DEVOTION TO DUTY, HAS ADDED

to THE ADVANCE AND Expansion OF THE BRITISH EMPIRE, AND WHOSE CHARACTER AND FXAMPLE IT IS MY AMBITION TO EMULATE, TIIS WORK IS, BX HIS LORDSIIIP'S SPECIAL PERMISSION, RESPECTFULLY DEDICATED ISY TIIE AUTIOLl. 

"It is held

That valour is the chiefest virtue, and

Most dignifies the haver: if it be,

The man I speak of cannot in the World

Be singly counterpoised."

Coriolanus. 



\section{PREFACE}

THE idea of writing a work upon the stirring events which 1 took place in Sierra Leone in 1898 was suggested to me by a General Officer who at one time in his career had seen a good deal of service in West Africa. On my return from that country in the following year he remarked that the difficulties and hardships of our "little wars" in that part of the world were not always appreciated by those at home.

Commenced in India-continued, as far as official duties would permit, in West Africa; and completed during my leave of absence in England-I now place this volume before the public, in the hope that all shorteomings will be forgiven. It is intended to be a plain statement of facts, and althongh I am aware that I have been unable to describe all the incidents of the various expeditions, and hare given none of the "Protectorate Expedition" in 1899, what I have said is, I believe, correct in detail.

If the hints on Bush Fighting and for the Preservation of Health will benefit any one in West Africa, and if the remainder of the work succeds in arousing any interest in that much abused part of the globe, I shall be fully compensated. My thankis are due to Sir Norman R. Pringle, Bart., Captain C. C. W. Troughton, G. Whiteley Ward, Esq., and to the Intelligence Division of the War Office for the use of their maps, \&e.

$$
\text { C. B. W. }
$$

Junom Amir and NAY Club, S.W.

$$
\text { June, } 1903 .
$$





\section{CONTENTS}

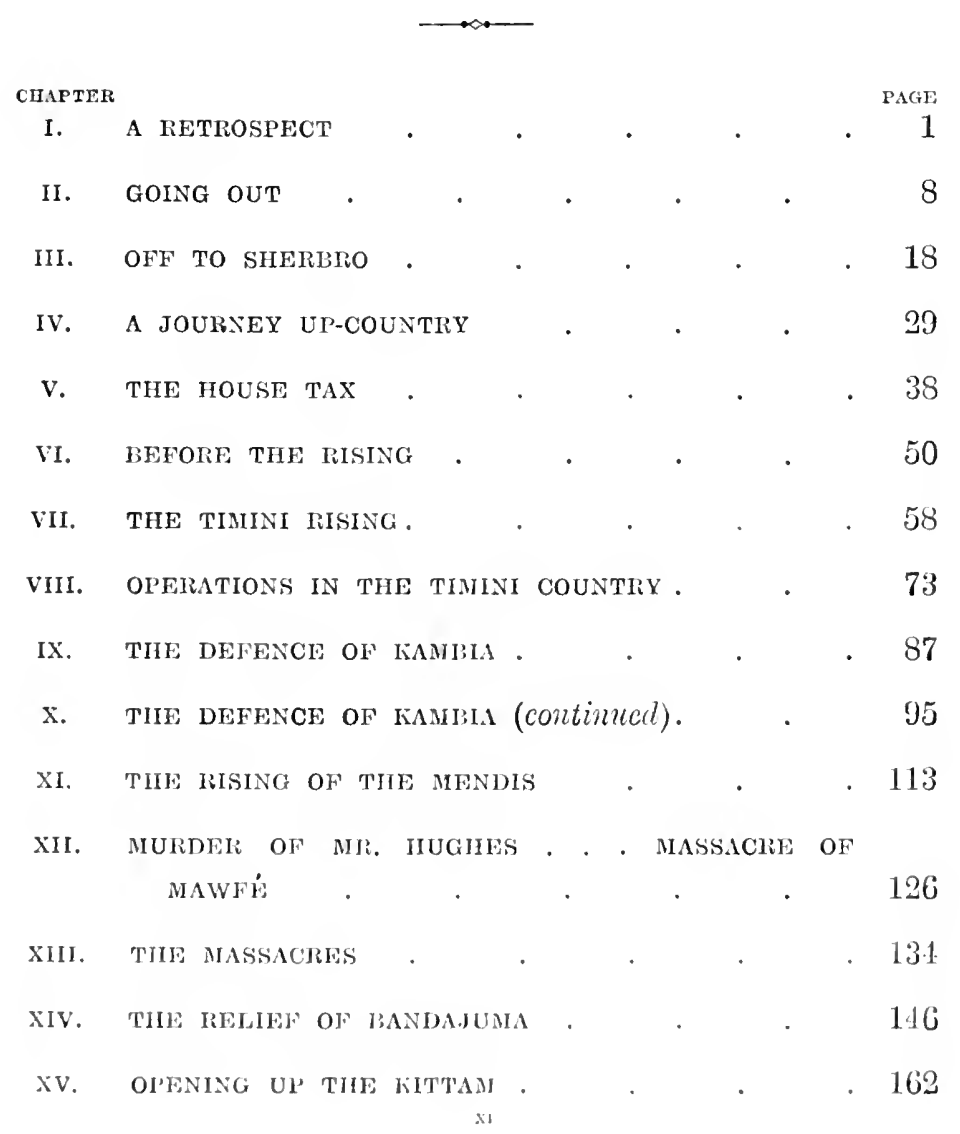


xii

CONTENTS

Chapter

XVI. OPERATIONS IN THE RONIETTA DISTRICT

XVII. THE END OF THE RISING 187

XVII. OUR I'OLITICAL ADMINISTRATION . . . 201

XIX. OUR COMMERCIAL POLICY . . . . 216

XX. OUR COMnERCIAL POLICY (continued) . . 226

XXI. FETISH AND SUPERSTITION. SECRET SOCIETIES 234

XXII. SEORET SOCIETIES (contimued) . . . 255

XXII. HEALTH AND EXERCISE. . . . 262

XXIV. BUSH FIGHTING . . . . . . 280

APPENDICES-

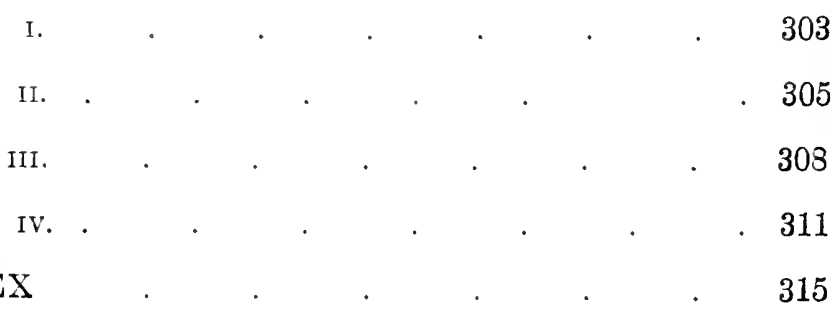




\section{LIST OF ILLUSTRATIONS}

PORTRAIT OF THE AUTHOR .
COLONEL SIP FREDERIC CARDEW, K.C.M.G., GOVERNOR OF SIERra leoNe, 1894-1900 • . . . . Facing p. 18

A SOLdIER OF THE WEST INDIA REGIMENT (p. 16) . • " " 24

CleariNG THE BUSH FOR CASSADA PLANTING • • • " 24

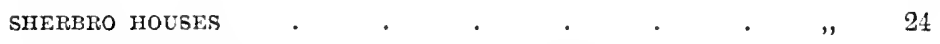

T. J. ALDRIDGE, ESQ., F.R.G.S., DISTRICI COMMISSIONER OF

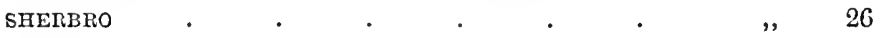

THE DIFFiCULTIES OF EUSH TRAVELLiNG (p. 32) . . " , 34

A HALT FOR "ChOP"-UP-COUNTRY TRAVELLiNG (p. 33). " 34

GOVERNALNT HOUSE, BANDAJUMA, THE DISTRICT COMMISSIONER'S RESIDENCE . . . . . . " , 34

DETACHMENT OF THE SIERRA LEONE BATTALION, WEST AFRICAN FRONTIER FORCE, IN LONDON, $1897 \quad$. $\quad$ " 61

ESCORT ENTERING A VILLAGE, UPPER IIENDIEAND $(\mathbf{p}, 39) \quad$. $\quad, \quad, \quad 68$

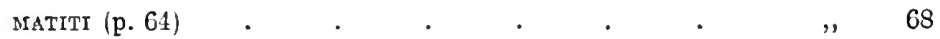

SERJEANT W. J. GORDON, V.C., AND PRIVATE WEST INDIA

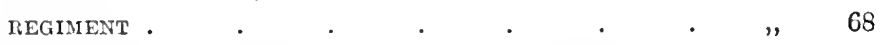

A soldier of THE SIERRA LEONE BATTALION, W.A.F.F., RECEIVING THE DISTINGUISHED CONDUCT DIEDAL FOR AGHANTI FROM SIR C. A. IING-MARMAN, K.C.M.G., GOVIIROR OF SIERRA LEONE $\quad$ * $\quad$ - $\quad 72$

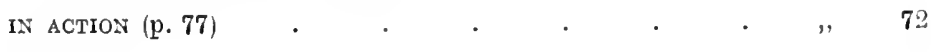
oN SENTRY-Go, LP-COUNTRY (p. 77) . . . . " $\quad 72$ 
FAREWELL TO AN OLD COMRADE (p. 86)

- Facing p. 91

CHIEF KOUNG

CHIEF KATAH OF LUAWAI

THE SMALL BOOM RIVET. THE PLACE From WHICI TIIE ESCAPE FLOM KAMBIA WAS MADE . . . . $\quad$ " 108

“PI.ESEnt!" the w.A.F.F. AT DRILl (p. 112)

108

KAMBBIA IREBUILDING. TIIE IFOUSE TIIAT WAS DESTROYED BY

THE ENEMY IS BEING REPLACED BY A NEW ONE (p. 112) 108

PIISONERS OF WAIR

116

CHIEF HONNo OF GERIHUN, ONE OF THE LEADERS IN THE

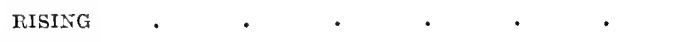

$\triangle$ CASE OF THEFT-NATIVE LAW (p. 128) • . . . . " , 116

THE ADVANCED GUARD IN ACTION, SHERBR EXPEDITION " 124

A RAIN-HAT, UPPER MENDILAND . . . . . . " " 144

A SOLDIER OF THE W.A.F.F. WHO FSCAPED DURING THE RISING .

"READY!" the W.A.F.F. AT DRILl (p. 166) • . . . " " 144

PEPOR, JONG RIVER, WHERE TIIF PANDAJUMA RFLIFF FORCE

LANDED

THE UPPER IITTAN RIVER (p. 166)

148

148

the late captain s. moone (p. 174) • . . . . . , , 148

TWO SERGEANTS, WEST AFRICAN FRONTIER FORCE . . " , 150

AMARA, PARAMOUNT CHIEF OF the TUNKIA COUNTRY (p. 158) , 150

OPENING UP THE KITTAM .

THE LATE MAJOR-GENERAL SIR E. R. P. WOODGATE, K.C.M.G., C.B., WHO COMMANDED THE TROOPS IN SIERRA LEONE IN 1898 .

major J. E. C. BLAKENEY, WHo COMMANDS THE SIERRA LEONE BATTALION OF THE WEST AFRICAN FroNtier FORCE . . . . . . . . "

MAJOR E. D. H. FAIRTLOUGH, C.M.G., D.s.O., DISTRICT COMMISSIONER OF RONIETTA 
HOW THE NATIVES GROW TREES ROUND THEIR HOUSES FOR stockade-Building . $\quad$. $\quad$. $\quad$. $\quad$. Facing p. 189

THE LATE CHIEF BATTE-KAKKA, WITH HIS TWO FAVOURITE

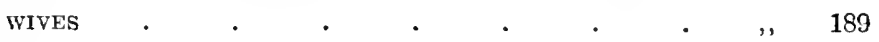

TIIE ROADS IN THE IMINY SEASON ARE OFTEN FLOODED

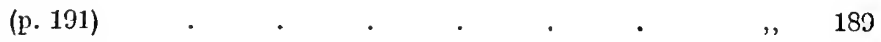

THE GOREe hiLl, malema CoUntry, Golaland (p. 191) , 189

VANDI-VONG, PARAMOUNT CHIEF OF THE JARWE COUNTRY , 190

CHIEF VANDI-VONG AND HIS TWO FAVOURITE WIVES . 190

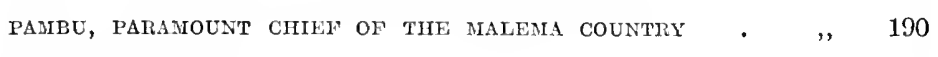

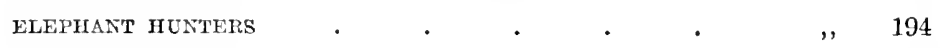

CROSSING THE MORRO RIVER ON A CORK-WOOD RAFT $\quad$ • , 194

OUR POLITICAL ADMINISTRATION. THE ARRIVAL OF A BIG

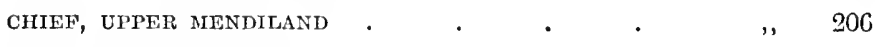

A CASE OF EMBEZZLEMENT. IN THE COURT OF THE DISTRICT COMHISSIONER

FASSIMBU, A GREAT ELEPHANT-HUNTER (p. 193) • • , 214

IIS EXCELLENCY SIR C. A. KING-HARMAN AND PARTY AFTER

A TOUR in the hinterland, february, $1903 . \quad$. , , 214

SIR ALFRED L. JONES, K.C.M.G. • • • • • • " " 218

THF GOVERNOR, SIR c. $\Lambda$. KING-HARMAN, HOLDING $\Lambda$ MEETING IN THE HINTERLAND (p. 212). * . , , 222

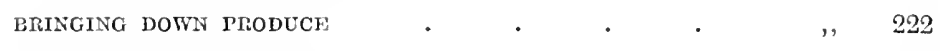

COTTON-SPINNING, UPPER MENDILAND $\quad$ • • • , , 222

MAKING POTTERY, UPPER MENDILAND • • • • • " " 232

A NEFALI DEVIL, MORRI FETISII (p. 236) • • • • " 232

BUNDU GIRLS DANCING (3 photos.) • • • • , , 250

MEMBERS OF THE HUMAN ALLIGATOR SOCIETY AWAITING

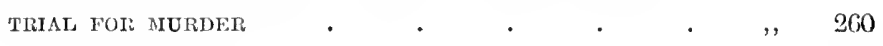

TIIF “FALI IN" SOUNDING-W.A.F.F. AT DRILI (p. 283) , 260 



\title{
The Advance of our West African Empire
}

\author{
CII A P TER I
}

A RETROSIEUT

"Man's inhunanity to man Makes countless thousunds mourn."

Buris.

HIDDEN away, yonder, on the dank West Coast of Africa I - a tiny spot of red betreen the Gambia and the Liberian Republic-lies one of Great Britain's oldest eolonies and one of the most important coaling stations and strongly fortified harbours of the Empire. That dot of eolour upon the malp of the Dark Continent represents Sicrral Leone and its recently amnexed Hinterland. Yet, insignificant as it appears when compared with the vast tracts of earth and sea by which it is surrounded, Sierra Leone and the Protectorate adjoining includes an area of some 30,000 squture miles-a country full of interesting and startling history. Here, in the good, or rather had, old days, the Portignese and others established the headifuarters of a gigantic slave trade; here, the ever-recurring inter-tribal wars caused the land to rum red with blood; here, the virious native "secrct societies"- 
the Alligator, the Human Leopard, and others-celebrated, unchecked, their fearful orgies of murder, rice, and a hundred other abominations; and here, finally, stepped in the British to put a stop to these horrors, and to frame a series of laws and ordinances by which they might protect and govern it. Their act directly and inevitably provoked a general conflagration thronghout the entire country.

The events of those days wonld fill many volumes. Yet, so far at least as I am aware, no consecutive account has ever yet been publisher of the native rising of 1898 and 1899. I have, therefore, somewhat diffidently, taken upon myself the task of filling in a small-a very small-portion of that hlank; and I do sn in the hope that, whilst many shortcomings may be forgiven, my narrative will he taken simply for what it is, namely, a plain, and, I belicve, an accurate, statement of the facts which immediately preceded and followed the outbreak.

Now, I will wager a moderate stake that a very considerable proportion of the British Public have never so much as heard, even, of the rising in Sierra Leone, and the terrible massacre which followed it. Nevertheless, the latter was the immediate outcome of a widespread plot, hatched with all the diabolical cunning, allied to secrecy, which forms so conspicuous a trait in the character of the indigenous African. Spreading, as it did, almost in a day, over an immense area, this conspiracy showed the nature of the Negro in all his primitive savagery and barbarism, a harbarism which generations of missionary effort towards civilisation seem, somehow, to have failed to eradicate, althongh one must confess that enormous strides in the right direction have been made. And when I write of Sierra Leone in this comnection, it must be understood that I am not referring to the Colony proper, but to the Hinterland, or, as the official documents have it, "the territories that lie adjacent thereto," and which constitute, indeed, the Protectorate. 
Here is a country every whit as uncivilised as ever are the Congo swamps of Central Africa to-day, a land reeking with fetish and superstition, and teeming with dark and bloody secrets. And here, it was, that in 1898, and part of the year succeeding, a handful of British troops fought grimly to maintain the supremacy of the old Flag; and here, too, many gallant officers and men lost their lives, either by the bullets of the savage enemy, or, worse fatc still! by the bete noive of tropical West Africa-the fiend Malaria. Here some of the most atrocions and treacherons murder's recorded in history occurred-nurders preceded by all the ingenious devices of torture of which the depraved mind of the African bush savage is capable. Black and white, old and young alike, were cut down and butchered in cold blood. Delicate white ladies were first outraged and then brutally done to death. Hundreds of educated Sierra Leoncans, elergymen, missionaries, traders and even innocent little children, were tortured, and afterwards hacked literally to pieces or burnt alive. It was a very carnival of slaughter, engineered by hordes of ruffians in whose veins ran some of the cruellest blood in all wild Africa. Mad drunk with spirits from the looted "factories," and thirsty for the blood of fresh victims, these wretches pursued their way, plundering, ravishing, buruing, and destroying as they went. And ever their rallying ery was "Death to the white man! Let us drive him and his 'civilisation' from our' country! We want neither. We want our slaves, we want cur 'women-palavers,' and wo-don't want the Honse Tax! Kill, therefore, every Lnolish and English-speaking nan,

"These are one of the main sources from which the chiefs obtained a certain amount of revenue and slaves. The chicfs and those who have a plurality of wives utilise several of then as "prostitute deeoys," who tempt the weak, and, after doing so, protest and claim eompensation for the injury which they pretend has been done them. Since the formation of the Protectorate in 1896, these "women palavers" have been nearly stamped out. 
woman, and child, black or white! Eren though it be our father or mother, our brother or our sister-slay every person who wears the white people's clothes!" This was the nature of the oath taken by every chief and man throughout Mendiland, and so strictly and literally was it carried ont, that their own children and near relatives, who conld talk a few words of English, or who wore any clothes other than the native dress, were murdered. But we mnst lie just : the majority of these people knew no better; from their infuncy and for generations they had been brought "I' to believe that the killing of their enemies, no matter how it was accomplished, was the great ain in riew, and, as I said before, the majority of them were ignoraut and wild.

There were some, however, who did know better. I refer to those who had been hrought up under the guidance of the nissionaries, and who understood and could themselves speak English. Blood being thicker than water, they, as soon as the rising started, threw in their lot with their own people; and strange and horrible as it may appear to our eyes, some of the worst and foullest murders were perpetrated by these very persons who had received their earliest education under the guidingr inflnence of Christian men.

The Mendi and Sherbro conntries were the worst. North, south, east and west, the messengrers of death ran fast. The cliefs and their headmen arranged the day to be deroted to the holoeanst, while everywhere the burnt palm leaf, the cmblem of war and slaughter, was carried, and over a thickly populated territory of some 25,000 square miles, the war-dogs were let loose.

The Mendi country and Sherbro were rapidly infected, as their inhabitants were the most ruthless, crnel, and treacherons. For these people are certainly lower in the scale than the Timini, the Susu, Fulla, Mandigo, or Vi. They are far more cruel and much more cuming, while liking danger less. There were comparatively few actual murders in the Timini comntry, 
though every prisoner of war was mercilessly killed, more often than not with tortures indescribable. For this, which we should term raw bntchery, the African bushman considers fair war-Autres pays, autres maurs.

Moreover, the native temperament itched for slaughter. His was a victory indeed when after a fight he was able to ent the throats of some half-hundred bound and helpless prisoners, or, better still, put them to a ghastly, lingering death. But he also wanted plinder. For long the showy goods displayed by the few traders scattered abont the interior, or, as it is called locally, "the bush," had excited his fierce cupidity and longing. Many and many a tine had le gazed with watering month at the contents of those stores, making stealthy note and speculating inwardly how he might get possession and at the same time cut the owner's throat. Well, he got his chance, and took it. And he has since arrived at the conclusion that the gane was hardly worth the candle!

Thronghout the protracted struggle it has to be said for him that the Timini fonght gamely and well, and made war, and not merely massacres. Rarely if ever showing himself in the open, his return of casnalties was ridieulously light for the nmmber of ronnds of ammunition that we expended on lim. The Timini it was who first commenced hostilities against us. The Mendi followed-fired, not entirely by his example, as has so often been erroneonsly suggested, but rather, probably, by a desire to wait and see first how their brother tribesmen fared in their resistince to the British Govermment. Still, the fact remains that the whole business was prearranged. It was, as has been said, a gigantic and carefully comsidered plut-a "prorn," or "one-word" war. And, thank God, it will go down in vur colonial history as the Plot that Failed.

Ever since our canliest aequaintance with it the whole of the great African continent lats been drenched in blood, a 
large proportion of which has been British blood, too. It has been shed frecly, eren lavishly; but what has been the return? What tally have we to count against those corpses of brare Britons who died so cheerfully for their country's sake for progress, the advance of cirilisation, and the expansion of Empire? North, south, east, and west, in all of those long years the dogs of war have been continually upon the hunt. And eren in this trentieth century, althongh at so much cost of blood and treasure Great Britain has held her own and acquired some hundreds of thonsands more square miles of both wild and fertile comntry, there can be but little doubt that yet more territory must be conquered, yet more blood spilled, yet more time and treasure spent, ere our raunted civilisation is to take firm rout in those strange virgin lands that lie lidden far off in the deep heart of Africa. The price we have had to pay for what we hare acquired has been a high one. What did the Soudan cost us to liberate from its thraldom? It may be, let us hope it is, the fact that after sixteen years of dominance Mahdism has received its final blow. But at what cost, England, the country that fights their hattles for half of oppressed limmanity abroad, alone can tell. Nevertheless, we have never shirked the task. St. George, the modern Perseus, secmed to account it his own peculiar privilege to slay the dragon of tyranny wherever met with, all the world across. And so to his ardour is due the fact that to-day the fillah is at lilierty to till his patch in peace and security, untroubled hy the demands of the holy inpostor, Abdullal Kerim, who took eight-tenths of all his crop and paid him in a text from Al Koran.

Turn next to the east, and it is fighting, fighting, always. And then come "Westrard Ho!" where for the last three quarters of a century we have been continuously contending with the native races in order that we might benefit from the commercial and other wealth in which this part of the continent abounds. 
So long ago as 1817 we were concerned with the suppression of a rising in Ashanti-land, and again in 1824, when a British force under Sir Charles McCarthy, the then Governor of onr Settlements in West Africa was taken prisoner, and beheaded by the bloodthirsty warriors of Kumasi.

In 1874 came the Expedition commanded by Lord (then Sir Garnet) Wolseley; the operations, in 1877, when Sir Francis de Winton took the field against the Yonnis, and more lately still, the Zebu Campaign of 1892, when, owing to the strategy displayed by our savage adversaries, we lost, in one action alone, fifteen marines killed, forty-seven wounded, in addition to many men of the native levies killed. Since then Great Britain has been employed unceasingly in crushing the power of the many hostile races in West Africa, including that of the wild tribes of fighting men inhabiting portions of Northern and Sonthern Nigeria, the Northern 'Territories of the Gold Coast, and those in the interior of Sierra Leone, who ruse and plotten for omr extermination. 


\title{
CHAPTER II
}

\author{
GOING: OUT
}

"My native land, good-night!"

Byron.

$\mathrm{I}^{\prime}$ was in January, 1898, that I received instructions from the Colonial Office to proceed to West Africa. Eight ditys was all the time I hail in which to purchase my kit, pack, and bid goodbye to friends in England; and although a rood deal may be accomplished in that short space, it is extraordinary, nevertheless, how many items will crop nj) at the last moment which appear absolutely necessary to take ont. Indeed, I found myself hard at work up to the very last maling purchases and arranging matters generally. The royage from Liverpoul to Sierra Leone is too well known at this time of day to require lengtly description; though possibly the beantiful Canary Islands-the "Isles of the Blest," as the ancients called them, not at all inaptlymay not be familiar to ereryone, lying as they do somewhat out of the beaten track of continental travel. Seven days' steaming saw us outside the anchorage at Las Palmas. At the time of our arrival, 7 a.m., a sea-haze enveloped the island in a mantle of white wool tlrough which nothing but a faint, blurred ontline of the harbour was visible fiom the steamer's deck.

As usual, we were surrounded directly after onr entrance 
by immumerable small boats manned by Spaniards having every imaginable ware for sale or barter. The Islands abound with fruit, which is indeed one of the staple articles of commerce. Another is cigars. If you are lucky in obtaining the gennine article, you are sure of a good leaf, and at a figure that is quite ridiculously cheap. But, as in the case of most foreign ports, one has to be very careful in nuaking purchases, and eren then, uuless one be a good judge of the tobacco-plant, one is almost certain to be taken in.

Even for a neweomer, it is not difficult to see at a glance to what comntry the Canaries belong. Everything smacks of Spain and of the Spaniard-the dark, bronzed faces of the men in their picturesque dress, topped by the broad sombrero; the finely formed and handsome women, with their peenliar headitress and immense earrings ; and, above all, the babel of voices uttering the soft liquil tones of the language of Calderon and Lopez, all point eonclusively to the nation of which these fairy islets are still an integral part.

When the sun had dispelled the mist, an hour or two later, the view presented was truly a magnificent one. In frout of us the town lay framed in a backgromend of richest green, with, away heyond it, the hills lifting their ragged summits high into the quivering blue. Indeed, their glorious transhncent sky is one of the distinguishing and characteristic features of these Islands, and one which I do not think cin be matehed by any other in the world. With assets like these, and a climate that varies seareely a degree between Janmary and December, it is small wonder, surely, that the Canaries have become the sanatorium, not only of Western Afriea, but for many parts of Europe also.

As our time was short-the steaner was to coal here merely and would leave that evening-most of us hastened to go ashore and see the "sights."

On first lamling I confess I thonght Las Palmas somewhat disappointing. 'The smo was now high above us, and right 
ahead the road wound, glaring white, for miles: away past the two fine English hotels, and onward through the heart of the town far up into the hills. All around us was fine sand, collected in silted heaps at every point about the harbour. It is said that this sand is blown here from the great Sahara Desert, and has been collecting for ages. It is perhaps open to question whether that is so or not. But what is indisputable is the fact that whenever the harmattan wind, which corresponds to the pampero of Sonth America, the levanter of Gibraltar, and the mistral of Provençe, blows across the Islands, the fine particles are caught up and driven away for miles to sea. Personally I can testify only to the unpleasant effect it has on land, where it blows into one's face, gets down one's throat, and is especially disagreeably felt between the fingers of the liands.

The English hotels on the Island were full of invalids, quite a number of whom had been invalided from the West Coast. This somewhat damped om spirits in the first instance, and those inveterate croakers, the Old Coasters, did nothing to remove the depression by the raw-head stories they were constantly relating to us of deaths from malaria, blackwater fever, and other ills that flesh is heir to in West Africa.

There is a fine open market place at Las Palmas, but the native houses were something of a disappointment. The streets are, almost without exception, narrow and dirty, and the buildings, many of which are of wood, low and badly constructed. On a later visit in 1899, I saw Teneriffe. This, as all the world knows, is a conical peak of some 12,190 feet in height, and is crowned by an observatory. We were many miles out at sea when I first descried it, and even at that distance it presented a wonderfully fine appearance. The apex of the triangle, far away above the clouds, gradually loomed nearer as we approached the land. At first, it was not at little difficult to realise that we were gazing at a 
momntain-peak, but by and hy it began to assume definite shape. More and more of its rast bulk beeame visible until, as we drew near the land, the whole of its majestic proportions could be clearly seen. Certainly it was a fasemating and absorbing spectacle. Indeed, one can gaze at Teneriffe for hours, and as the Zulus say, "yet be hungry to see."

So much for the Canaries. Every one who ean should see them, and lneky are they who can eseape an English "cold weather," and the dank London fogs to winter there.

After leaving the Canaries, we sailed into beantiful, balmy weather, a smootlı sea and fair blue skies accompanying us to within sixteen hours of Sierra Leone. Two days south of the Islands the awning had been rigged; and we began to feel the benefit of it, too, for almost every homr now the temperature was rising. It was already intolerably hot, with a fierce white glare upon the water, when we drolped anchor in Freetown harbour at half-past nine a.m. on the fifteenth day out.

For some hours before the order to "let go" was given, we passengers had been on deek ogling the low horizon through telescope and binoculars for the first sight of land. The newcomers amongst us were much struck by the beanty and pieturesque appearance of Freetown, viewed from seaward. And it must be confessed that the place does, when seen from a little distance, look really fine. The densely wooded hills behind the town, erowned by the white barracks of the West India Regiment, the hxuriant tropical foliage, and the Cathedral (one of the few stone buildings in the place) all combine to form a cliarming picture when seen from the deck of an in-coming ressel.

"Yon would not think that the place was such a deathtrap, would you?" was the lugnbrions remark of one of the Old Coasters, as we stood watching from the deck. One certainly would not. Indeed, the approach to Freetown Harbon forms, I think, perhaps the most picturesque vista 
that I ever remember to have viewed, and one which never fails to make a favourable impression on every new arrival.

One thing especially which struck me on my initial introduction to West Africa was the extreme verdancy of the foliage. Everything about the landscape was so deeply, so richly, so wonderfully green. No sigin anywhere of the burnt-np grass and disconraged and sickly-looking trees, so commonly to be observed in India during the dry season. And the higher up the slopes one looked, the deeper became the tints of tree and bush; and this, too, notwithstanding the mighty glare of an African sun, which beat down relentlessly upon us from the zenitl. Probably this riotons lusuriance of regetation is acconnted for by the extreme lumidity of the climate, a feature common to all this part of Africa. Travel where you will, coastrise, or for hundreds of miles in the interior, and you will find that same moist atmosphere, so faromrable to forest growth, so trying and so enervating to persons fresh fron Enrope.

Almost before our cable had rattled through the hawsepipe, we were surrounded by a flotilla of small craft, crowded with specimens of some among the many tribes which inhabit this part of the continent. Then, in addition, there were the Medical Officer of Health, the Customs people, the Harbourmaster, some stray military men, and various local oflicials, all of whom had come out to meet us, and incidentally to learn the latest news from home. We were a good big party on board, all of us bonnd for some part or other of the Coast. There were seven or eight military officers besides myself, and a sprinkling of civilians and tralers. His Excellency the Governor (Colonel sir Frederic Cardew, K.C.M.G.), very kindly sent off his entter with his A.D.C. to bring us ashore, and with the former was Major A. F. Tarbet, C.M.G., D.S.O., Inspectur-General of the Sierra Leone Frontier Police, and two orderlies.

And now came the collceting of our baggalge, a somewhat 
tedious business, as in most cases this was numerous. Knowing that in any erent the greater part of it would be stopped for examination at the Custom House, I instructed one of the ordcrlies, a smart young Timini of the Frontier Police, to seize my small portmantean and kit-bag. These contained personal "nccessaries" only, and having them scenre, I did not care greatly how long the Customs authorities retained my other impedimenta.

On the steamer a slight breeze was blowing, cren though we were at anchor. Once, however, we were in the launch, and there was a marked difference in the temperature, though even this was nothing to the roasting we had to mudergo on shore; and although I was wearing a large cork helmet, of the kind known in India as a "solar topec," and a thin flamnel shirt, I felt the lieat rather severely. It ecrtainly was tropical. The reddish ground reflected the sun-glare like a burning-glass, and for dozens of yards around a misty sheen was visible, quivering in the steamy atmosphere. We streamed with perspiration, and before we had walked twenty yards I was wet to the skin, and as generally uncomfortable as one always does feel on one's initial introduction to the tropics. Freetown, too, in the dry season, is a particularly warm corner, and, ringed in, as it is, by lofty hills, very little breeze finds its way into the town. Even the sea-breeze itself secms to hecome heated and danped by its passage over the bmining grome, and its free entry is further checked by the many intricacies of the streets and buildiners. As a matter of fact, this wind from seaward is rather more dangerous to Furopeans than the heat itself. Every evening it blows snartly landward, chilling the atmosphere, and, at the sanne tine, the bodies of nnwary foll, who at first are only too slad to avail themselves of these pleasant, if langerons, dranghts of air. But the body, which has been sweltering all day long in a temperature approximating to sone $94^{\circ}$ in the shade, camnot stand so great a shock, and chills and fever supervene quite naturally. 
The more one sees of Frectown, the more disappointed one becomes. A closer inspection of the buildings shows many of them to be in an extremely dilapidated condition. Wood everywhere-of white, brown, or bilious yellow colour; this from the sea makes an excellent imitation of stone, and is very deceptive. The streets of Freetown are long and somewhat narrow, and in many of then grass is growing!

The borders of the principal thoronghfares are linerl with matives selling goods from stalls or from the ground; piles of fruit, cheap paper wares, calabashes, clay pipes, cotton handkerchiefs, and all sorts and conditions of clay ornaments are conspicuous. The more substantial native tradesmen stand inside their shops. These are, as a rule, nothing more or less than open sheds, arranged with shelves and protected by a roof of wood, straw, or grass. The scene, especially for a newcomer, was picturesque and fascinating in the extreme. Crowds of men, women, and children were passing to and fro, some with huge pitchers or baskets on their heads, others bearing great bundles on their backs, while the idlers lolled about with an appearance of having 110 aim or object in life but to do nothing and to keep on doing it. The costumes were both gorgeons and varied. Snowy-white clad Mohammedans stalked in flowing robes alongside the Timini or Mendi from the interior, mother-naked with the exception of a single loin cloth. The civilised gentleman of Sierra Leone was, of course, conspicuous with his immensely ligh collar, immaculate patent-leather boots (not from Bond Street or Piccadilly), shiny "topper," correct frock coat, and dazzling white waistcoat. But by far the most striking amongst all the inhabitants to be seen about the streets were the women. Gorgeous and varied were their costumes, pretty and even strikingly handsome many of their faces, while nearly every one boasted a figure that Juno herself might well have envied.

The African lady is, when young, much to be admired. She generally possesses a jovial countenance, and wears a 
peremnial smile, which shows conspicuously her dazzling white teeth. Her figure is always graceful; she is as straight as a dart, with arms and shonlders round and plump as polished ebony. Her costume, simple as it is picturesque - that is, when it is built "country fashion"adds to her charm. A loose gown of gaudy colours is wound around her waist and sometimes flung over her shoulders to hang down on one side in graceful folds. Her well-poised head is covered with a many-coloured kerchief, and her woolly hair curled and twisted as only a native versed in this mysterious art knows how to do it. Along with her is to be seen the more civilised young lady, who corresponds quite closely to the exquisite in the high hat, frock coat, and patent leathers. She has probably spent her youthful days under the care and tutelage of a missionary in some local school. She generally turns ont in a wonderful speckled blouse and rainbow-tinted skirt, while on Sunday her costume, hat, and parasol are nothing short of gorgeons, and ape the ultrafashionable garments to be seen in Hyde Park or Bayswater. It is not strange, therefore, that neither her figure nor her appearance are anything like as pretty or as graceful as her more unsophisticated sister in the toga. Her bringing up has been so different. She has not from her infancy curried baskets and pails of water on her head every day, which is one chicf canse of the graceful development and symmetry of fignre in the other. She is fettered, moreover, by tight shoes, high collars, and other abominations of European genteel society. To this should be added the deleterious ellect of being kept indoors, while the veneer of gentility she gets sinuply tends to render lier umntural, eramped, and often blotchy as to her complexion. In shan'p distinction to both of these is the elderly dame, the Sierra Leone "mammy," as she is called locally. This lady always appears to be smilingly contented, and has a greeting for everybody.

When two "mammies" meet they will always "tell each 
other how-do," Sierra Leone English is a quaint and interesting language of itself, quite unintelligille to the nerreomer.

First mammy: "Mar, how you do to-day?"

Secoud ditto: "Yes, mar, thank God!"

First ditto: "Yes-O!"

We stond watehing this scene for some time, afterwards passing up the principal strcets which cut the city into so many lines and sections. Then, as the smn had declined considerably, and a refreshing breeze was blowing anite briskly from the sea, we set off to nerotiate Mount Oricl and Tower Hill.

The West India Recriment have fine quarters up here, well situated and from all arconnts exceedingly healthr. Indecd, the barracks and mess-honses are the best-built places in the town-Government House, perhaps, excepted; and besides being cool, with a fresh hreeze nearly always blowing, the drainage is escellent, and everything, of conrse, scrupulonsly clean and well cared for.

This was the first time I had seen a soldier of this fine regiment. The West India "Tomny" is a fine follow, tall, broad, and well sct np, and his kit, with the Zouave jacket, sputs, red fez, and white pugaree, gires lim an appearance as soldierly as it is picturessue.

by the time we had refreshed ourselves, chatted and left our cards, it was growing dark, so we said adien to our hospitalle fricnds, and returned to the town. We dined at 8.30 p.m.; there was a large and jolly party round the dinner table that evening. Althongh nearly all the Frontier ofticers were away up-conntry, the mess was lively cnongh, including, as it did, numerous honorary members. For cirilians as well as soldiers take advantage of their hospitable board, and nearly every ofieer staying or passing through Freetown, fed, and when room offered, put up here also.

One's first tropical night, even when surrounded by white 
men and civilisation, is always impressive. When dimner was over, most of us moved out to the verandah to smoke and talk, and amidst the inky darkness ontside one conld hear the incessant chirp, or rather scream, of the ericket, the croak of the grass frog, and the numberless other somnds and noises so common in Africa, but which seemed at first so strange, and even weird, to the newcomer. 


\section{CHAPTER III}

OFF TO SHERDRO

"Long is the way, and hard."

Militon.

TWAS up and astir early on the following morning. This 1 is by far the best part of the day in the tropies, and, in fact, in all hot countries. Then the air is comparatively fresh and cool, if not actually lracing, and work, whether in or ont-door, can be carried ont with a degree of comfort impossible later in the lay.

On this day I was to have my official interview with His Excellency. I donned my best uniform, therefore, and set forth for Government Honse, where, amongst other matter's, I had to be sworn in as a Justice of the Peace. I need only add, in this comnection, that sir Frederic Cardew was exceedingly kind during the short chat, of some twenty mimutes or so, which we had together, and gave me some excellent advice.

This formality over, I retumed to my quarters, where my marching orders shortly followed me. These were to the effect that I was to proceed immediately to the Bandajuma District, a journey, via Sherbro, of some ninety miles by steamer, and thence some five days' march overland. For the railway was not then.

Next day I set to work mpon the selection of my stores. 


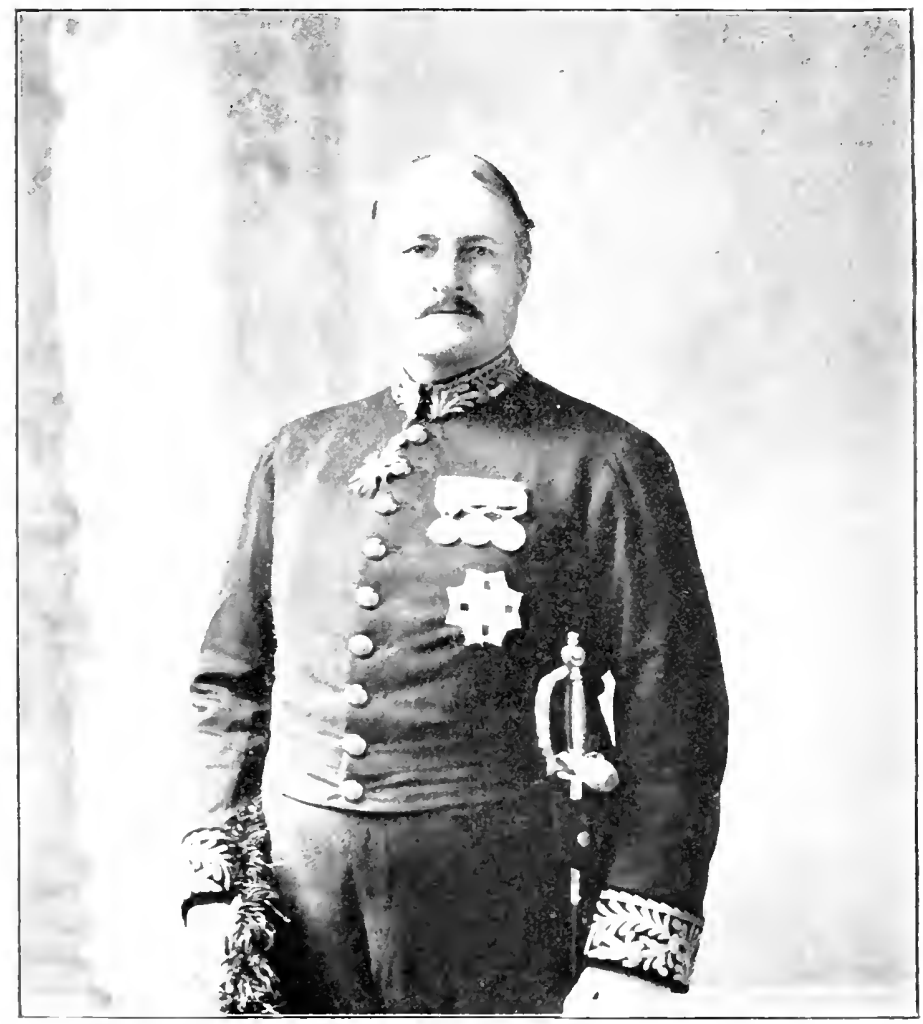

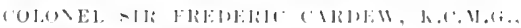

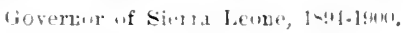



I do not think I need trouble the long-suffering reader with details seriatim of the hundred and one articles necessary for a bush jommey. Suffice it to say that they included everything needed by the traveller, from a folding deck-table to a stock of timed tomatoes.

By the time everything was realy and in marching order, I had been three days in Freetown. I put in the remainder of my time in making a few necessary calls, and in improving my acquaintance with the place. A short wutline of the history of the Protectorate of Sierra Leone may not, therefore, be out of place at this juncture, since, althongh the colony proper has been written abont many a time, the Hinterland, or "Protectorate," as it is ealled officially, has not been much heard of.

It was, then, in 1788 that Sierra Leone first became part and parcel of British territory. At that date King Nebana sold to one Captain Taylor, a patel of land extending from St. George's Bay, up the Sierra Leone river, to Gambia, and inland for abont twenty miles. There were at this time in England, ant especially round about London, several negroes who had been for some reason or other separated from their own eomtry, and the idea of anepniring land in this part of Africa for a hone for these destitnte blacks resulted in a treaty with the aforesaid ruler of Sierra Leone-King Nebana-and the acquisition of the comntry named abore.

Later on, when Sir Fowell Bnxton was making heroic efforts in the Honse fu bring in a Bill for the abolition of the slare trade, the Colony was used for resened slaves and African exiles, and other's who, for personal reasons, hatd left their own country to seek shelter under the wing of the British. Since then the Colony has been steadily growing, and many more coneessions have been reecived from the native kings. Two chicfs, named respectively Tom and Farma, ceded the western portion of the peninsula in 1S07, and fifty-fomr years later more territory was aerpired from the ehief of a comitry known 
as Kwia, the area of which was some 160 square miles, lying between the Ribi and Sierra Leone Rivers. Another treaty was ratified in 1825 by the Governor of the Colony with the chiefs of the Sherbro Island, and other adjacent countries, for the purpose of increasing the boundaries of the Colony. Sereral further treaties were made, and the Colony now includes an area of 300 miles, between $6^{\circ} 55^{\prime}$ and $9^{\circ} 2^{\prime}$ of North latitude, up to Kiragba on the north-east, measured from the Liberian border-line, where the Manoh River forms the bomdary. Two blocks of land, one measuring 14 miles long by 23 miles broad, and the other about 80 miles by about 100 miles in breadth, extend in a north-easterly direction. The former of these is claimed to be actually the oldest portion of the Colony, while the latter forms the district of British Sherbro. There is also a thin strip of land ruming along the sea coast of about threc-quarters of a mile broad. The idea of securing this strip was to guard and control the importation of merchandise. Numerous other treaties have been made from time to time with the varions native kings, the prime objects of which were to open up the comntries ruled over by these potentates, for the protection of British subjects, such as merchants, missionaries, and others, and the abolition of the numerous petty wars, which at that time were so numerons in the Hinterland.

The capital, Freetown, is, of conse, a port of immense importance to Great Britain. It has excellent coaling appliances, a good and sheltered harbour, and is exceedingly well defended, both as regards forts and by an Imperial gatrison, consisting of a battalion of the WVest India Regiment, the native Royal Artillery, the West African Regiment, armed Civil Police, and the Sierra Leone battalion of the West African Frontier Force, which latter, however, is utilised to a great extent in the Protectorate. The population of Freetown is abont 80,000 . The inlabitants are not by nature given to agrienltural pursuits, and the soil is poor, and 
thongh Sherbro does a large trade in palm-kernels, rice, and palm-oil, the greater portion of these are brought down from the Hinterland.

The first impression a man reccives of the interior of this part of Africa is that it has an immense "bush," with foliage so thick that in places it is impossible to see more than a few yards into it. Giant trees, especially the cotton-tree, surround one on all sides, and the narrow, winding bush-path curls its erratic way like a hnge snake for hundreds of miles through the network of trees, shrubs, and other vegetation, the many species of which it is almost impossible to name.

Truly the scenery is matchless in its quiet beanty, and in the waste and riot of its tropical profusion. Here, indeed, is Nature, sweet Nature! mopoiled by the pruning hand of vandal man; far away from the sordid erowd of man-made towns, far from the bustle and turmoil of his puny, artificial existence. Here in God's own garden the reverent mind, searching diligently, may find a friend in every tree, a meaning in each leaf and tiny bursting but. Insensibly, lut surely, the grandenr, the majesty, the all-pervading spirit of the Great Anthor sinks into the soul, exalting the greatness of the Infinite while teaching us our own ntter insignificance in the scheme of Creation. No wonder if, once one has glimpsed at these perfect vistas, there comes a longing to return and gaze, and gaze again. "Drink Nile water and you must come back to drink of it once more" says the old Egyptian proverb. And that is no less true of Western Africa.

"Far away in this swcet solitude,

Man must think and wonder at the marvels of Creation."

At midday, when the sun is directly overleat, throwing his rays with all his force on to the tops of the trees above you, the bush is still gloomy; and at night, even with a full moon, it strikes the traveller as being the blackest and loneliest of 
all the black and lonely places in the world. And yet one knows that it teems with life-on crery side one has eridenee of this. Abore, below, and on both flanks, birds, bcasts, and thousands of insects are heard, though one can, and does, march for miles sometimes without seeing a living thing, with the exception, perhaps, of the driver ants, and other stinging inseets, which abound on the paths and trees in the daytime.

As you pass along your way, the scenery changes. Sometimes there is a pateh of fern swamp belted by giant bamboos, with their smooth and willowy branehes shooting straight up from the ground. Anon, you pass through dense patehes of evergreens and ereepers, thousands of them, with the ubiquitous palm elose by in the background. Proceeding on your way-perhaps for a score of miles-you come suddenly upon an immense forest, thick with giant trees of all descriptions, the gnarled cotton tree more conspicuous than most, with its twisted roots and fantastic shapes and turnings; and so on till the end of your march, the scenery for ever varying, but always the thick dense bush, be it forest, creeper, palm, or bamboo, enveloping you ou every side. The Hinterland of this Colony, or, as it is ealled officially, the "Protectorate," is, in fact, one dense mass of bush and forest, with an estimated area of orer 30,000 square miles. All over it are dotted the towns and villages of the aborigines, and it is a very network of paths and by-paths, mostly native, comnecting village with village, and joining river to river. A few of these paths-a very few-are Government roads, or rather traeks (for roads, as they are understood with us, do not exist in the Hinterland). Some two yards is the average breadth of a Govermment road, and the endless pools and small streams which intersect these are "corduroyed " or bridged in a most primitive mamer by the chiefis or headmen oceupying the town nearest them, by order of the Government. The pupulation of the Protectorate is unknown, though it has been 
ronghly estimated at some two million souls. Its depth is abont 210 miles, and 180 miles from East to West. The comtry is well watered, and many of the rivers are deep and rapid. In parts the soil is fertile, and on it are grown indiarubber, cotton, gum, kola-nuts, while forests of palm trees are met with on every side. It is as yet mileveloped, and, indeed, unknown in some parts, although the revenue and a large part of the trade of the Colony depend entirely npon the Hinterland.

There is always one paramount chief over each country, who has a lot of power. His towns are governed by subchiefs or "headmen" who obey him in all things and are responsible to him personally. The British Governnent now look to the paramount chiefs for the proper ruling of the individual territories, the encouragement of trade, and the payment of their taxes. 'The chiefs have of recent years, since the rising, been loyal to the Government, and have paid their taxes with regularity, and vast strides have been made for the general betterment of the condition of their peoples. For the purposes of government, the Hinterland has been divided into districts, five in all, each mider Commissioners and Assistant-Commissioners. The names of these districts are: Ronietta, with headquarters at Moyamba; Bandajuma, with headquarters at the same place; Karene, with headquarters at Mabanta (this will probably be changed); Panguma, with headquarters at the sane place; and Koina-Dugu, with headquarters at Kaballia. Besides the Commissioners, with their Civil Staff, there is generally stationed in each district one company of the West African Frontier Force under two or three officers, a medical officer of the West African Medical Service, and very often a missionary, who is, however, not an official. In addition, there are a number of minor officials, such as clerlis, medieal dispensers, interpreters, and others.

Intermal tribal wars have been waging from tine to time in 
the Protectorate for centuries, the chief causes of which were the disputes arising from sale and l,arter and the kidnapping of slaves. These wars not only derastated the country for miles, but prerented any of the nore cirilised native inhabitants of Sierra Leone from going into the interior to trade. It was principally on acconnt of these ererlasting disturbances, and in order to abolish slave trading and open np arenues of trade with the interior, that, after the ratification of various treaties with the French, who surround us here on all sides, and the deliberations of divers Boundary Commissioners, a Protectorate mas declared in 1896.

To resume ny narrative:-On the erening of my departure we walked down, after dimer, to the quay, and were soon on board the Colonial steamer, where we met the skipper, Cap,tain Compton, R.X., who allotted us berth; and kindly arranged for the strrage of our necessary landbags in the three cabins. sleeping below, eren in a big steamer, of Sierra Leone is truing work; hut when attempterl in a small boat like the old Countrss of I J rloy the thing became, at all events, to people like ourselves, new to the tropies, a phrsical impossibility. By the time we har got under way it har been decider hy unanimous consent to bring up our nattresses, and, refying mosquitoes, ferer, and every other plague, to sleep on deck. The night happened to be pitch dark. There was nothing beyond the boat risible, except a few stars that peeped dimly at us from the relret dome above. Ererything was still sare the throb of the engines and the occasional call of the man on watch. Even the Krm-boys had stopped their chatter on the forward deck; only now and then a spar creaked or a rope rattled noisily as a sea canght the little boat and lifted her gently over.

It was nearly six when the rim of the sun peeped orer the low horizon. We lad run into the so-called Sherbro Piver, and numerons islands, large and small, appeared and reappeared as we surged along upon our way. As yet there had 

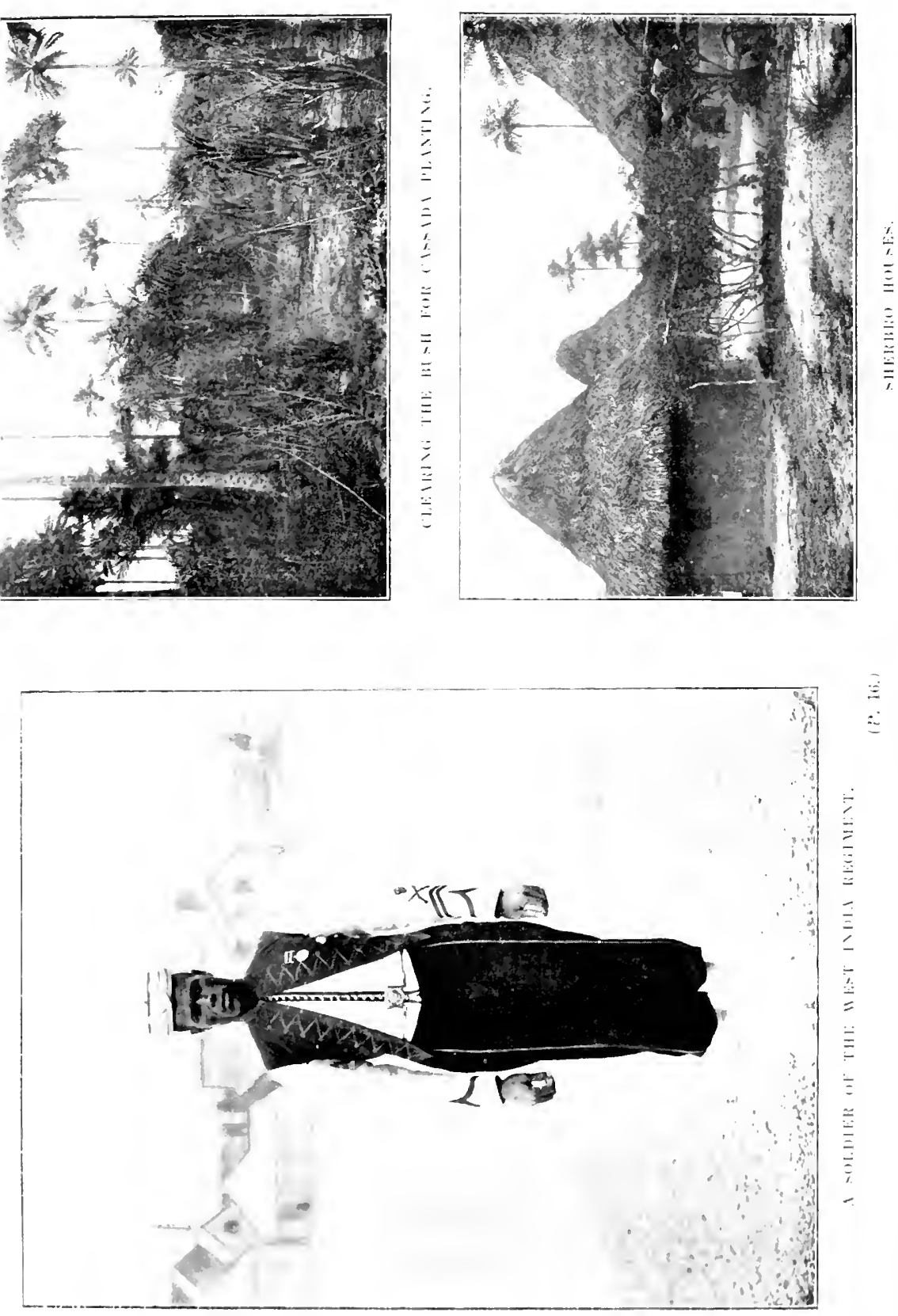

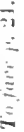



been nothing of interest to see. Now the river, which at this part is some ten miles wide, began to narrow, and soon on either hand we had a view of the banks, in many llaces mere morasses of slimy mud and decayed vegetable matter. Next, acres upon acres of mangrove swamps-the typieal feature of the low-lying West African coast scenery-swung into vicw, and one nosed the sickly taint of crushed marigolds, which is the prevailing odour of the waters here. It was still too near the river mouth for very many alligators to be seen, but here and there a huge specimen could be deseried basking on a mudbank, his ugly body, cased in triply-rivetted armour-plating, looking as nearly like a lon of stranded driftwood as it was possible to do. Higher up-stream, when the sun is at its hottest, and the water ruming low, these brutes are quite common objects of every landscape, so numerons are they.

By eleven o'clock that night we were quite close to Sherbro, and half an hour later dropped our tiny anchor into the slime nearly opposite the landing-place at Bonthe.

Sherbro, as I have already mentioned, is really part and parcel of Sierra Leone, and does, in fact, belong to the Colony proper. It comprises an island, or rather a series of small islets, whose situation is flat, swampy, and utterly uninteresting from the seenic point of view. The place is, howerer, by reason of its geographical position, the headquarters of an enormous trade, both Emropean and native, and boasts very many handsomely construeted "factories" with airy residential quarters attached. Here, also, reside the factory agent and his subordinates, sometimes for years together, mutil they are ahle to retire on a hardly-earned competence, or, what is far more likely, get carried off by the combined effects of elimate and malaria. Nevertheless, Sherbro will continue to be an important flace, no doubt, since it is the entrept for the entire trade between the interior and the coast, and a large business is done with the natives in palm oil, nuts, kula, rice, and other eommodities. 
It was the intention of Captain Compton to remain at Bonthe for a few hours in order to afford us an opportunity of ealling upon the District Commissioner; and, further, it wonld be necessary for us to embark here the carriers to conrey our baggage and stores up-country. We should finally leare the steamer at Bendn, a town on the mainland about fire miles higher up than Bonthe, and sitnated on the opposite bank of the Sherbro River.

Mr. T. J. Alldridge, the Commissioner, whom I had the pleasure of meeting here, had alreadr been "on the Coast" for more than twenty years, and had traselled orer sis thousand miles in the interior. He gare me the impression of an exceptionally healthy man, despite his long residence in this trying climate; and was, in his own person, an excellent example of the adaptability of the Enropean for life in any part of the world prorided he looks well after himself, and takes the necessary precautions for maintaining health.

From the Commissioner's house, which was sitnated at the far end of the town, orerlooking the water, and within five minntes of the Government landing-pier, conld be scen the large river, or, rather, conflnence of several rivers, for quite a long distance, north and south. Opposite, but far away in the dim distance, wound-a faint blue-the ontlines of the Imperri Hills: a country still steeped in fetish and all manner of nameless evil-doing; a land wherein the Alligator and Human Leopard Societies even now practise their horrid rites. Right and left, far as the eye conld reach, was the dense bush, over which the straight-ringed stems of palm and cocoa-mut, crowned with feathery tufts of foliage, towered like the "masts of some tall amiral" riding on a sea of deepest green. Strange and unfitting was it that this fair vista should of all become the theatre whereon was shortly to be enacted that dreadful drama of blood and rapine, which was, eren as I looked, already in active rehearsal under the dread stage-nanagement of Death. Let so it was to be. 


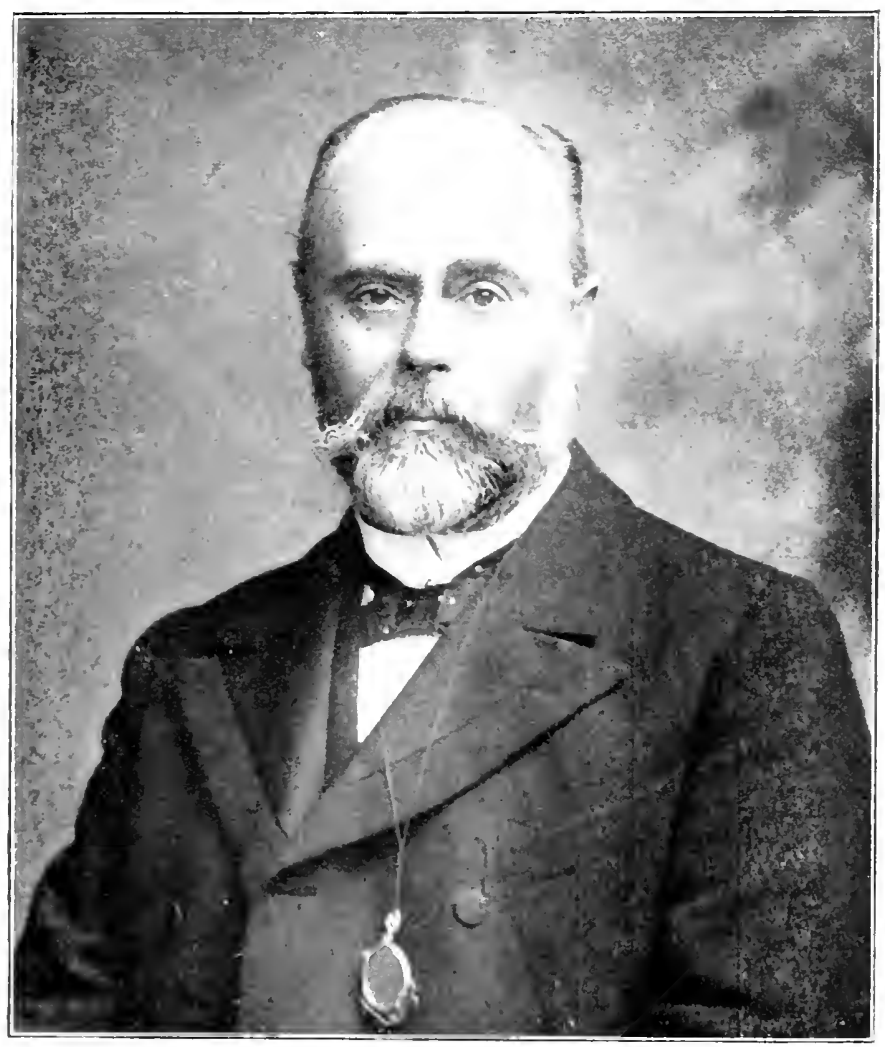

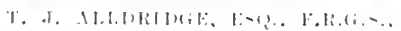

bi-triet commissimer of Sherliro. 

Within a few short weeks the belt of tangled forest land beneath those green fantastic hills would be the seene of many a cold-blooded crime of murder preceded by tortures more horrible than pen may write of, of reckless incendiarism and wanton destrnction of property and dwellings; in short, of all the unimaginable lust for villainy which characterised (and perhaps still characterises) the people who inhabit this seeming earthly paradise. Through these leafy labyrinths the wide-mouthed rivers, still salt from their late eontact with the sea some fifteen miles below, pushed their erratic way, their banks close overhung with tree and vine-elad undergrowtlı. Actually, only one river was visible from Bonthe itself; but three others, the Jong, the Small Boom, and the Boom-Kittam, all of them important water-ways, came down near by to swell the volume of turgid water that flowed smartly out to sea.

We had not time on this occasion to explore Bonthe thoroughly. But we noticed that all of the principal buildings stretched in a line with the Commissioner's house along a frontage of some two miles. Amongst the more important of these were the Court-house, prison, and police prarters, the Court Hall (which was comnected with the Commissioner's residenee by a corered way), the large "factories" * of the Sierra Leone Coaling Company, the French Trading Coupany, Messis. Piekering \& Berthoud's warehonse, and other smaller shops. One eould purchase at Bonthe nearly everything that one required in the way of stores, crockery, elothes, tobacco, and ironware, thom prices were even higher than those of Freetion.

Sluall as the island was, it yet boasted its "ling," who

"The word "factury" is a misnomer. There are no factories on the Coast as the name is understood in Europe. "Factory" in West Africa is the local name given to the warehouses, producereceiving depots, and other large shops in the up-country trading centres. (Aurnor.) 
rnled also over the various towns and villages scattered amid the neighbouring bush. A little, spare sarage was the Beh of Sherbro, to whose sly face his smattering of eivilisation had lent but an additional comning. This worthy was, it shonld be said, considered a man of very great importance by the people, lucally, and, indeed, many of the neighboning up-comntry chieflets were not above coming down here to obtain the benefit (?) of his adrice on any matter of importance. By this miscreant many of the atrocions murders shortly to be committed in the neighbourhood were deliberately planned, and he it was, also, who organised the intended wholesale massacre and pillage of the island. I had the pleasure, later on, of seeing him escorted on board one of Her Majesty's war-ships, though he ultimately escaped pmishment, the direct eridence of his guilt heing, unfortunately, too slender to justify his execution. He was nevertheless banished from the Colony.

Of late years, Sherbro has been, comparatively speaking, in a somewhat more civilised condition, though the process is still, and must be for some time yet, a slow one. As an official on the spot since wrote to me, in India, "very little progress in the way of real advancement has as yet been made. The people have no ideas beyond kernels and palm oil and ' for full dem belly.' Perhaps one day," he adds, " in the far distant future, a change may come over the spirit of the country, and it may come more into line with the civilised nations of the world. But there is very much to be done before that liappy state of things becomes a "fait accompli." "

Our carriers were soon collected, after which we returned on board and the Countess of Derby carried us across to Bendu, a distance of some five miles. Here our baggage was put overside into a boat to keep company with our noisy crew of porters, and we were shortly plumped down upon the beach and found ourselves once more upon the mainland of the African Continent. 


\title{
CHAPTER IV
}

\author{
A JOURNEY UP-COUNTRY
}

"The road lies yonder, thro' those belts of trees."

THE march overland to Bandajuma would occupy five days, 1 and this being my first experience of travel in the bush, I was anticipating it with no little interest. But I had reekoned withont my carriers. I wonder, has it ever fallen to the lot of the inexperienced newcomer to be suddenly set down in the midst of a party of unruly West Coast carriers, with indifferent headmen, and no military escort to overawe or coerce them into good behaviom? If it has, he will know the sangnine (?) feelings with which I set to work to allot his load to each of these gentry, every one of whom was perfectly awire that he was practically master of the situation. If my realers be experts in this sort of thing, then they will sympathise with me all the more keenly in the task I had of silencing the babel of complaining roices which arose as I endeavonred to lick that stragghing nob into something approaching marching order, preparatory to a long day's tramp through the bush miler the glare of a West African sun. From the moment a move is contemplated up to the very last second befure the stant, it is a physical impossibility to hear one's own roice, much less make it heard by others. I am, I trust, as long-suffering ats my neighbums, but your West 
African carrier would seriously try the patience of $\mathrm{J}$ ob himself.

You begin, let us say, by carefully assembling your force of porters in squads, each mider its own headman, whom you try to make understand that he will he held personally responsible for its collectire orderliness and oledience. Haring, by the aid of much gesticulating, aecomplished this (or so you fondly believe), yon proceed to the more delicate task of allotting to each man the load he is to carry and to which he is to cleare throughout the joumer. Now the African native, like the rest of limmanity at large, prefers to get through his day's work with the sniallest amount of tronble and incunrenience to himself. And to accomplish this laudable end, there are no lengths to which he will not proceed, no strategem he will not readily adopt. The loading of a file of eamels is mere child's play to this. He will quarrel, and snarl, and argue for hours, if you will let lim, with his fellow-porters, with whom lie enters on interminable discussions as to the relative weights of the loads, the single purpose he has in riew being to obtain the lightest and nost portable for himself. by this time, mobably, you are as loarse as any erom, and as nearly in a temper as it is possible fur a man of your amiable disposition to hecone. Chohe it back. Tou are as yet only at the berimning of your task. Yun now give, as fiercely as you know low, the order to "pick up luarts"-in the Mendi tongue "alika moomion!" At this summons a fer--a rery few-loads will possibly be hoisted. Fou next pay particular attention to the careful lifting of one of your specially valuable boxes, upon which you have had your eye from the rery nnoment that it left the steamer. It contains, let us say, your entire stuck of liquid comforts, or the only breakable set of crockery that you own. Tou have only mosed away for half a minute when you turn at the sound of a tremendous crash, followed by a rolley of cries, to find your one and only tea serrice smashed into a hundred fragments, or your stock of 
lime-juice cordial oozing away into the parched earth; while the dusky gentleman to whom it was entrusted lies inextricably mingled with his load upon the ground. After much more shonting and threatening of the headmen with instant extermination if such a thing occurs again, you once more give the order to raise the loads. If you have any kind of luck, the majority of your porters will this time have "headed" their burdens, and at the signal to "march," the procession starts off in single file. You heare a sigh of relief and congratulate yourself that your troubles are at an end at last. Not a bit of it. You have only proceeded some two hundred yards when there is another awful crash, and you hury forward to find the fragments of your only glass reading lamp strewing the sward, while the eulprit is legging it as hard as he can into the bush. Other parties are meanwhile sneaking off on little private expeditions of their own after a cassava or pineapple which they have spotted growing handy near the path. The new incident is, of course, the signal for a lot more jabber, and the business of readjusting the loads has all to be gone through once again. Fon are probably, by this tine, in a murderous frame of mind, and to ald to your miseries you are wet throngh with clammy perspiration and well-nigh voiceless from shouting-and all this before you have much more than fairly started on your march. I went throngh this little comedy (only I hardly saw the humour of it) more than once during my first "trek" in the wilds of the Sierra Leone Hinterland. But it is quite wonderful how rapidly you learn to manage eren such a happy-go-lucky gentleman as the West Coast carrier'; and, grown skilled by sad experience, I think I would now molertake, with small loss of time and temper, to move a crowl of natice porters from any one given point to another through the bush, and without much fear of damage, either, to the transport.

The occurrences which I have narrated at some length above were all happenings of the "old" days-the time 
previous to 1899 , that is to say. Matters have altered, and very much for the better, since then. Grood headmen are more easily to be obtained and a military escort invariably accompanies all European officials travelling with porters in the bush. Further, the carriers themselves, if given their "chop" regularly, and treated with kindness and forbearance, are, as a rule, capital fellows to get on with, and are capable of transporting yourself and your loads over distances of from ten to twenty miles daily, without showing any signs of being knocked ip.

On this, my first journey up-comntry, I was five full days upon the road. The first night I slept at Pangba, a small native town in the lower Bullom comntry. The next evening we reached a place called Bharmar, which I remember chiefly as teeming with some of the most venomons mosquitoes it has ever been my ill-fortune to encomter. We resumed the march after a most mucomfortable time, and arrived on the third night at a town ealled Bramah, where, however, nothing worthy of narration happened. The next day found us encamped at Mo-Bongo, and the one after that at Jimi, which place is the headquarters of the Upper Big Boom comntry, whose chief, rejoicing in the name of Koker, has been a noted warrior in the past, as well as an inveterate slave-raider.

A little incident occurred here which I may appropriately mention, illustrating, as it does, not only the natives' complete indifference to sanitary measures of any lind, but also the same fatalism in the presence of grave danger from contagious sickness, as one frequently reads of in the chronicles of Mohammedan nations. Whilst strolling around this town some little time after our arrival, we-that is, Dr. Horrocks and myself-noticed several persons going about whose skin was smeared with a kind of chalk, giving them a most weird and ghostly appearance as they came and wont in the twilight betwixt the close-set rows of huts. On my inquiring of the chief who these parties were, he informed me that they were 
persons who had lately recovered from a bad attack of smallpox, adding the cheering remark that several people had lately died from this terrible malady in his town. Poor Dr. Horrocks very nearly had a fit on hearing this intelligence. He at once commenced a close cross-examination of on' friend the chief, with the object of eliciting whether any smallpox patients had died in the actual house that we were then inhabiting. Fortunately, his chiefship was ahle to assure us that 110 one had, so far as he was aware, died or even been inside our residence. Nevertheless, it was only after his repeated assurances, and that of others, that we cunld bring ourselves to enter our domicile, or even persuade ourselves to remain the night within his gates. I give this incident merely as an example of the clesagrements which the traveller has to jut up with when wandering in the Hinterland of Western Africa. In time, it has to be said that one grows callons and indifferent to such drawbacks.

Being entire strangers to this part of the country, we were constantly under the necessity of inquiring of our native followers the distanee of one town from the next. Very eurious is the loeal method of reckoning this. Whilst travelling from Mo-bongo to Jimi we were informed that the latter place was "very far." The fact is that the natives hereabouts have only some three or four phrases in which to refer to distance, and until you have been in the country some little while, and have got to "know the ropes," you suffer much perturbation by reason of the rongh-and-ready notions that the inhabitants have of such matters. For instance, when a Mendi, Timini, or any other native tells you that the distance to such and such a town is "little far," there is 110 knowing whether he means an homr's stroll or a four hour's' hard tramp. Again. if he says, it is "far too much," mything between seven and fourteen hours may he implied. But if he talls you it is "fir, far away"- "lia-lia" is the Mendi word-yon may ahandon all hope of getting to yuur destination that day. 
The distance from Jimi to Bandajuma is some twelve to fifteen miles only, and the road runs, the whole way, through very fine scenery. On louking at nuy diary, I find that we mored off at 6.15 a.m., the "thin black line" of carriers liaring started balf an hour previonsly. At ten o clock we halted for breakfast, lwiling our water for tea at a fire, built gipsy-fashion under the trees at the roadside. We were now within an hour or two's march of Bandajuma, and, in fact, reached our lestination just upon midday. Here we found the Officer Commanding the Frontier Force at this station inpatiently waiting for us.

The paramount chief of Bandajuma was one MIomokiki, then an old man of considerably over eighty years of age. His father was a Fulahman, and his mother a Mendi, and the old gentleman himself wiclded an immense amount of power in the country. This chief, who succeeded MIomo-Fulah, receires a stipend from the Gorernment and holds a commission to sit with the Commissioner in Court on certain occasions. By religion he is Foula-Mohammedan, and has plenty of shrewd common-sense, and a great hold upon his people.

As for Bandajuna itself, the place is nothing more or less than a huge clearing in the bush, and consists chiefly of native-built "bungalows," in which the non-commissioned officers and men of the Frontier Force live with their wives. Besides these there are the military and medical officers' and commissioner"s quarters. These are also native-built houses, consisting, as a rule, of two rooms and a rerandah, as well as the native hospital and Conrt-honse.

The town is situated on a slope bounded on the west by the Wantje River, a tributary of the Kittam, and on the other three sides by the prineval forest. At the time of which I an witing, everything lere was in a very rough-and-ready state. Now, however, things hare changed enormonsly for the better. Substantiul wooden bungalows have been erected fur the Commissioner and the European officers of the Govern. 


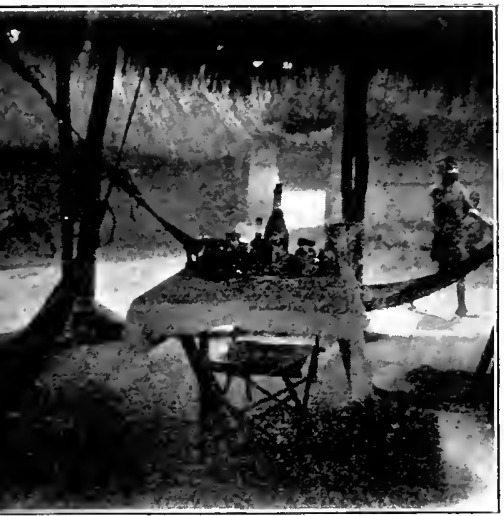

I HILT FHR " CHIOR',

Lu Country Travelling.

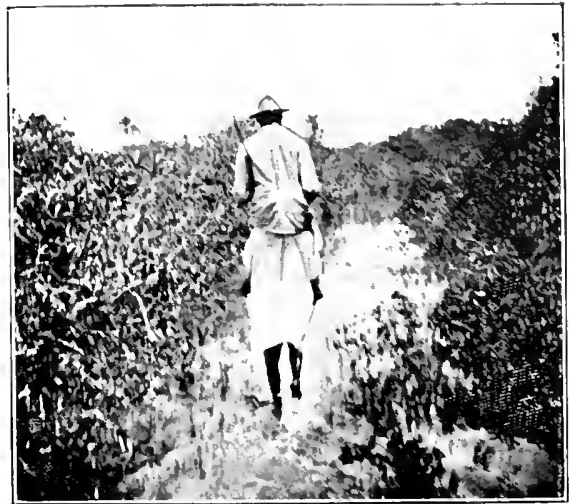

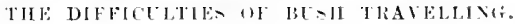

$(1,3: 3)$

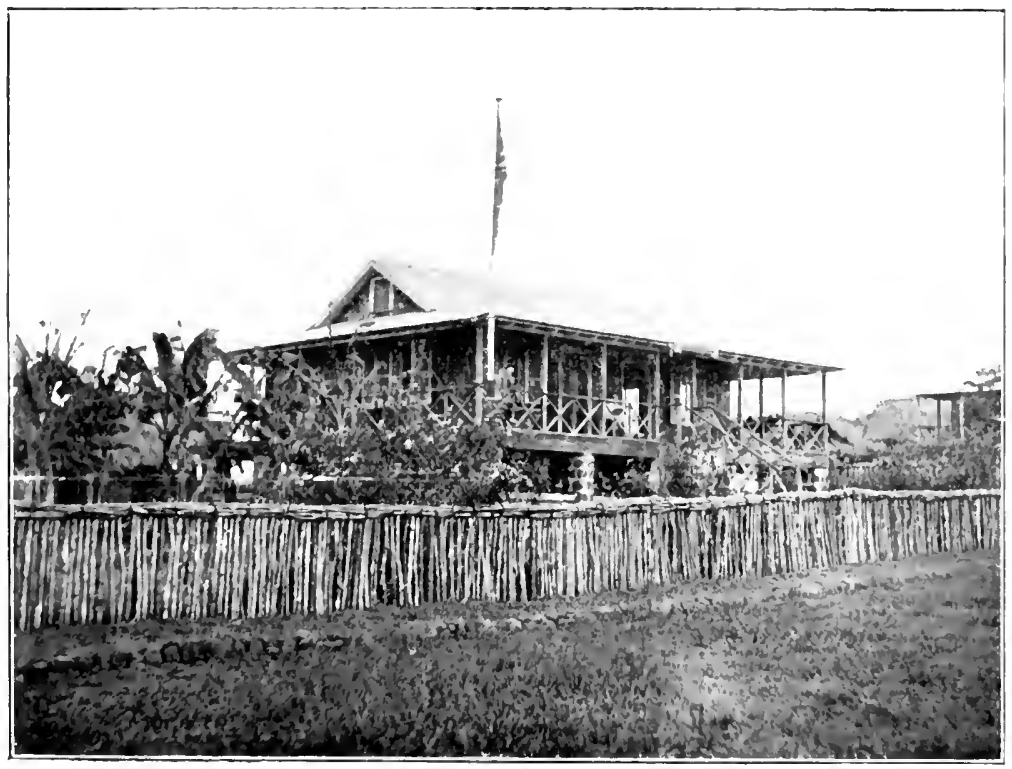

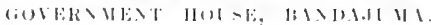

"The Distriet lonmissioner"s Resilence. 

ment, and in many other directions great strides lave been made.

Captain E. C. Miyne, of the Frontier Force, was at the moment the only ofticial European resident in the station, the Commissioner being away up-country endeavouring to explain to the natives the objects of the House Tax, and the reasons why it had to be paid. Although at this time the district appeared tranpuil, there can be 110 donbt, laving regard to subsequent events, that a diabolical plot was eren $110 \mathrm{w}$ in process of being hatched and that the natives had already made np their minds to drive the white man and everything connected with him out of their comtry.

On the day following, Dr. Horrocks started off' on his fivedays' march en route for Panguma, the headquarters of the district situated to the north of us. Here he was to be stationed as Medical Officer in charge, and here he was destined to undergo, within a very brief span, probably the most trying and exciting period of his life.

As I have indicated before, the Goverument officials were at this time much occupied in endearouring to collect the House Tax, which hald come into force in the Jannary previons. I had not been established at ny new post more than four or five days when an urgent dispatch came up from the Governor to the effect that every availible official was to proceed on a similar duty. I, consequently, found myself obliged to start at once, with au escort of twenty men, and a few porters, on a collecting tour dow the Big Boom River.

This is one of the principal trading centres of the district, and the banks of the Boom River are, or were then, dotted with "factories" the owners of which did an important trade with Sherbro by water. The lower portion of the river is noted for its mosquitoes, which for multitude and voricity are hardly beaten, even by those of Bharmar. On my third night out I stayed at a town caller Barmani, where those pests are so ferocious that sleep withont a curtain was simply an im- 


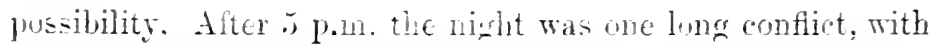
the victory a-sured from the start $f, r$ the attacking force. At length. in self-defence. I har to shove my legs into long "cum-honts," and, in spite of the hert, wrap myself tightly in a waterproof elouli, and cren then my assailants fonnd a way of biting me.

Ten days later, after liaring made an extended trum lown the Boom River, and vicited on the way a number of chiefs and towns in this part of the emintry, I arrived at a place called Bahal. Here I hal ny first experience of fever and dysentery, and it was of the usual minleasant character. Worse :till, I had $n$ medicine whatever with me except quinine. After strugghling against fiate for two days more, I was compelled to do what I shunld have done at first, namely; send a messcuger drwn by boat to Sherbro-a jommey of two days-for the medical dresser. He eame as quickly as he could, of course, and, with the aid of castor oil, quinine, and laudanum, in a few days set me on my legs again, although I felt rery weak for some time afterwards. I shall hare something to say in a later chapter as to the simple precantionary measures which new arrivals on the coast would do well to observe, in order to cruard against the malurial attacks almost inevitalie in this eountry.

During this tour I interviewed. as already stated, several of the more important chiefs, whom I informer, as pleasantly as I could, that whether they liker it or not the tar would have to be paid. Althongh none of them actnally refused, in so many words, to do so, it was abmiantly clear that they did not like the notion of leing muleted one little bit. An numistakable sign of the way the wind was lowing lay (had I been somewhat more experienced in native ways) in the fact that on arriring in serelal of these toms the greater portion of the inhabitants rould bolt incontinently into the bush. Nowhere was I hospitaly receired. I reeollect well one old chief naned Bemi, of Bungel, in the Kenur country, 
at that time possessed of considerable anthority locally (and whom I afterwards found it necessary to arrest for treachery), telling me that he entirely failed to understand why the Great White Qneen shonld require money from such poor people as themselves. I laboured hard to explain to him and his friends that every country had to pay a tax for its upkeep, and that the contribution they were invited to make wonld be expended solely upon securing the good government of the conntry. I further reminded them that in former days they had had nothing but continuous wars when no man's property was safe. But now the British Gorermment had come there to put an end to those wars and to give them, instead, justice and a stable government. They were simply asked, in return for these benefits, to contribute their due quota towards the uplieep of this necessary refime. I saw that my hearers more or less grasped the sitnation, and my arguments, lnt I. am afraid the latter made no praticnlar impression upon their minds. For everywhere I went the people were sullen, and there were rery few women or chilitren to be seen-ilways a sign of trouble. 


\section{CHAPTER $Y$}

THE HOCSE TAX

"Min who prefer any load of infamy. howerer great, to any pressure of tacation. however light."-SYuxey SMith.

$A$ ND now for a few work of explanation of the House Tax, Protectorate, and the means of collecting it. as well as of the modus operandi of the British Goremnent in their ruling of this comntry generally.

As has already heen said, the Protectorate of Sierra Leone came into ofticial existence in 1896 , the actual date being the 31st of Angust in that year. In anticipation of the arrangements necessary for governing the Protectorate an Order in Council was made on August 24, 1895, to the effect that Her Majesty had acquired jurisdiction in certain foreign comitries in West Africa, adjacent to the Colony of sierra Leone, and it was ordained that it would be larful for the Legislative Council of that Colony to provide fur giving effect to all such jurisdiction by ordinance or ordinances, before or after the passing of the Order in Conncil in the territors adjacent to the Coluny.

In 189.1 1895, and $1896 \mathrm{Sir}$ Frederic Cardew made rarions tonrs in the Hinterland with the object of acquanting himself with the whole Coluny and Protectorate. 
In 1894 a journey of between 600 and 700 miles was taken, beginning on March 27 th and ending on May 17th. In 1895 another tour was made of 598 miles, lasting from Jannary 30th to April 5th. The last tom that His Excellency made covered 675 miles, between Jamnary 29th and April 5, 1896. Ronghly, quite two thousand miles were travelled by the Governor in the Hinterland. During his first tom in 1894 he found slave-raiding and slave-trading actively proceeding and the comtry at large in a rery disturbed state. A war was being carried on in the Tehwa country in Liberia, which is only separated from the British sphere of influence by the Manoh River. Across the Morro Piver also, the Mendis and the Golas were fighting. Also a parmonnt chief named Kai Londu, living just on the Liberian border, liad raided the Konno country, devastated it, and taken the paramonnt chief prisoner. The great chief, Niagna of Pangmma, was also abont to carry war against the same Konnos, in spite of the fitct that this comtry had recently been devistated by the Sofas. In other parts of the Hinterland things were much the same. The Kranko and Kunili countries were hostile, and a slave-raiding war was being carried on by the two big chiefs, Fumbo and Fusa, of the Sanda-Lokko comntry. The Governor found that the traffic in slares was going on everywhere. At Mongheri, Kintaballia, and Jarra, he met caravans of slaves whom he caused to be set free. During these tours the intended government of the comtry in finture was carefully explained to many of the ehiefs by the Governor in person, at the varions places which lie visiter.

In January, 1896, the Governor held a big meeting at a place called Matinafor, in the Kwia comntry, where also the Protectorate Ordinance was explained to several piaramount chief's and the proposed seheme of taxation detailed. 'This was, that every onner of a halitable house in the Protectorate would on .Tannary 1, 1898, be liable to a tax of tive shillings, and for lionses of four rooms or more, ten shillings; whilst 
for every village whose number of houses was under twenty no tax wonld be imposed. The amomt could either be paid in cash or kind, that is, one bushel of rice, or one bushel of palm kernels wonld be taken at its trade value as equivalent to cash. The average ralne of a bushel was between three shillings and five shillings, and this, notwithstanding the fluctuations in price, would be accepted for a house of the smaller lind. The inerease of the revenue was a necessity, and in most parts of the Protectorate the means of realising the Honse Tax were at the people's very hands. There are thousands of palm trees in nearly every part of the Hinterland and especially in the south, and rice and kola are found everywhere, whilst in most of the five districts rubber is foumd.

Now the tax which was imposed in the Nyasa district of British Central Africa was three shillings a month per head. In the territories of the Upper Niger there was a tax of one shilling and sevenpence per man. In Liberia every male over twenty-one years and residing within the Government's sphere of infuence has to pay a tax at the rate of six shillings and threepence per annum, and there is no difficulty in collecting it. In Basutoland the rate was ten shillings in 1885, and since then there has been an increase; and in Natal every Kaffir pays about two pounds per liut. So the tax of five shillings which was being imposed in the Sierra Leone Protectorate was not unreasonable, and by no means ont of the power of a majority of the inhabitants to mect.

The Governor also held a large meeting of chiefs in the Masimira country, where again the Ordinance was explained and the taxation question thoroughly thrashed out. Several other meetings were held, at Madina, Bendiboo, Karene, Boomban in the Shengai-Limba country, and at Kambia on the Great Skarcies River. At all of these places the new Ordinance was carefully and lucidly explained through the interpreter. Tery much care, trouble, and thought were 
exercised by Sir Frederic Cardew in all his many tours; and although in several instances the Tax was not exactly welcomed by the ehiefs with eagerness or acclanation, no direct refusal to adhere to its terms was, so far as is known, reported to the Governor. The only exception was Niagua, of Panguma, who, the Governor remarked, "was very truculent," but seeing his people afterwards, he reported that they acquiesced. Another chicf remarked at one of the meetings that he preferred to be muder the English Govermment to the old days when there was no peace. At the same time, it should be stated that after he left the varions districts showers of petitions were received by the Government begging for the recission of the House Tax and fur a modification of several clanses of the Ordinance.

After the Order in Council, an Ordinance entitled "An Ordinance to determine the node of exercising Her Maljesty's Jurisdiction in the Territuries adjacent to the Colony of Sierra Leone," was passed on September 16, 1896, and was at once bronght into operation, thongh the enactments regarding the House Tax were not to come into force until January 1, 1898. An explanation of the Ordinance was prepared in Octoher, while printed eopies of the Ordinance itself were sent to several of the principal chiefs in the Mendi comntry. The District Commissioners were directed to give as much publicity as possible to this Ordinance, and to explain its essential details to the native ehiefs. Also a Govermment messenger was sent bearing copies to the Timini chiefs, and this min visited Mabele in the Marumha comtry, Maghena, Port Lokko, Sanda Lokko, Balam, Kwia, and other places. At first, it alpueared as if the chief's wished it to be thought that they did not molerstand the meaning of the Ordinanee, but when they saw that things were being pushed forward, and that there was little good in their pleading ignoranee, " notes of disapproval hegan to appear." Several written petitions were sent to sir Frederic Cardew, one of the first 
being from Bai Simera, dated Octoher 26, 1896. His letter was to the effect that his slaves would become free by going before the District Commissioners, that the porrer of the chiefs in holding their courts wonld disappear, that their wives wonld leave them, and, worst of all, "in 1898, tax must be paid on every honse from five sinillings to ten shillings, which will bring down a heary burden upon ns, when we consider our poor state in which we live." Also on Octriber 20, 1896, the Boompé chiefs in the Mendi country sent a petition, saying that they were mable to abide by the new instructions, such as "the paring of Land Tax and House Tax," and one year after this, these Boompé ehiefs sent a representative to the Governor to explain matters. "The most principal is the House Tax, and we are not opposing, but we are really poor, and not in a position of paring; therefore we humbly pray that His Excellency will pity our case in this respect."

On Nuvember 9, 1896, Pai Kompah, Chief of Kwia, asked to be permitted to appeal direct to Freetown instead of going to the Commissioners' Conrt at Kwaln. Also on the 3rd of November in the same year, Madam Yoko, Queen of the Lomer Mendi, submitted a letter to the Governor, saying: "As this being a new Ordinance which we are not accustomed with, we shall make a trial of it, for we do not know what it is like ret." Another petition was sent to the District Commissioner of Karene on December 17, 1896, for submission to His Excellency by the Chiefs Bai Forli of Mafurki, Bai Faremal of Saflnoko, Bai Shakka of Dibia, Bai Bureh of Kassi, and Bai Kawarri of Tendo-Tufu, to the effect that the clauses in the Ordinance respecting trade licences, domestic slaves, House Tax, and the remoral of their power in courts, should be abolished. In December, 1896, sixtyfour chiefs sent a letter to Sir Samuel Lewis, the mofticial leader of the Bar at Freetom, asking him to put it hefore the Goremor. This letter was in much the same strain as were 
the others, and pleaded poverty against the Itonse Tax. A large petition, in which the paramount chiefs of the Kwia and Timini comtries joiner, was sent to the Governor on June 28, 1897, and embodied the following objections:-

(a) That the chiefs now considered all their ancient rights and power were at an end, as they were deprived of their right of licaring lawsuits regarding their lands.

(l) That the Tax will make the people poorer than they are at present, who are too poor to pay this Tax, and conserquently the burden will fall upon the chiefs.

(c) That their own family slaves should be allowed to remain with them.

(d) That the building of gaols in their comtry shonld cease.

(e) That their ancient rites and customs shonld not be interfered with, "except such as may be deemed inconsistent with the laws of God,"

The same petitioners sent a further appeal on September 18, 1897, requesting that it should he forwarded to Her Majesty, and on the 15th of Octobcr they sent mother petition to the Legislative Conneil in Sierra Leone, which stated that certain fucts had cansed them "to believe in the possibility of the worst of all news, namely, that the Governor intends to make them pay for their huts or "sleeping places," and on the 26th of October they sent at telegran to the Secretary of State for the Colonies, asking for a renction in the Honse 'tax. Upon this the Governor made certain eoncessions, the most notable of which were that the chief's would receire a small commission on collecting the Tax, and that temporary firm buildings shonld not be taxed at all. On heing informed of this, a further letter was sent to Sir Frederice Cardew on Norember 15, 1897, in which was stated that they thought that " the Goverment womld take their comitry from them; . . our own trine four is that

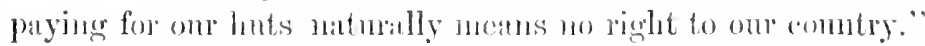

shortly after this, the 'Tinini whefs rebund to their 
homes in silence, and withont giving their consent to the new laws. Some chiefs from the Mendi country came to Freetomn and had a personal interview with the Guvernor, without any result. They were from the Boom and Kittam countries, and Bai Kompah, King of Kwit, sent a petition on Jannary 2, 1S98, in which he stated his "inability to pay the tax."

It will be seen from the above with what repugnance the people regarded the New Ordinance, and especially the laws relating to the Honse Tax, and what a difficult task Sir Frederic Cardew had imposed npon himself, by putting into action his earefully thought ont and able policy, one which is being followed to-day in the Protectorate with marked success. He hat met with opposition everywhere, and even the traders in the Hinterland in many instances exhorted the natives not to pay, and to petition the Government. His rork was made more difficult from the nature and indolent habits of the people with whom he had to deal, "for it must be rememhered, that this was not a "no-man's land' which was being dealt with, or vast tracts peopled only by a few wandering herdsuen, but a populous territory, which hatd been for ages parcelled ont, and under definite gorernment, althongh the plane of cirilisation might be far removed from a European standird." But the natives were, nevertheless, sarages, emel, treacheruns, emming, and bloodthirsty. These were the people whom sir Frenteric Cardew had set limself to enlighten, and to govern jnstly, while insisting on the abolition of slavery and wars which devastated the whole comtry, which "extended alung the whole length of the cuast from Rio Nmez on the North to the Nanoh Piver on the Sonth." His sole aim was to turn the Protectorate into a responsible Government, and, by maling the Hinterland self-supporting, and imposing a $T a x$ on the lazy inlabitants who were able to pay one, and who were anxious enongh to seek British protection whenerer necessity arose, to spare the drain un the resonices of the Colony proper. 
It cannot, therefore, be a matter of surprise that the ignorant aborigines of the Hinterland, encouraged by their chiefs, who foresaw, on the advent of the British flag, the abolition of their slave laws and native orgies, and the demand from them for a contribution, in the form of the House Tax, for the up-keep of a Govermment they did not want or understand, that bloodshed should be the result. More so, as they were indirectly encouraged by the people of Sierra Leone-a number of whom are only half educated and eivilised-and also by the local press.

Having received copies of the Ordinance in Octuber, 1897, the District Commissioners commenced the difficult task of explaining the eontents of it to the people in their districts, and went earefully into details of the Tax seheme. Out of the five large distriets, only three were to become liable to taxation in Jannary, 1898. These were Karene, Bandajuma, and Ronietta. In Bandajuma, in the early part of 1898 , every available officer was tonring on Tax duty, and several important meetings wore held. The inhabitants, though showing no open hostility, were sullen and reserved, and on three occasions Captain Mayne was foreed, through the temper of a head clice in the Koya eominty, to attend these meetings with a loaded, thongh concealer, revolver. Dr. Arnold, District Surgeon of Bamlajnna, while travelling on Tax duty, was nearly mobbed by a crowel of natives at a town called Gbar.

The following extracts from a letter written by Dr. Armold and sent to the District Commissioner, dited fiom Dorlo, Jannary 5, 1898 , will grive a good idea of the state of the comtry at this time: "I left Gorahmo on the morning of the 3rd inst., having had great tronlle in obtaiming arriers, and, consequently, making a late start. 'The chief of this town seemed to be mwilling to renler me any assistance in obtaining men. Reached Gbah about sunset; several carricrs and one hammock boy deserted on the way. Remainer at Gbal 
Tuesdidy, the th. Fut as shortly as pussible, what intppened at Gbah was this: The town early in the munning beeame full of an anned crowd of matives, fresh hands continnally conning in, headed by their chicfs, mitil several Inudreds, at least, must have arrived. I could at first obtain 110 information from the corroral as to the incaning of it all, although, from the fact that every min in the town, old or young, was armen, and from the sinister scowls they gave ne, it was evident that mischief was intended. None of my escort conld interpret, eren moderately well. After a palaver anong themselves, the chiefs and their follower's assembled outside my house, and a very cxcited and angry mob, they were. Every moment of some two lours' time an attack on myself and men seemed imminent-the slightest untoward incident or hindling spark would, I an sure, have caused our instant massacre, for the Frontiers" were all unarmed-a fortunate thing, I think. We were surrounded by hundreds of men, most of then armed with antique guns, swords, spears, and some with clubs. I held the chiefs in converse as best I conld with such indifferent interpreters, but I am inclined to think that it was due to the intiluence of a man named Mousa of Filo, who arrived in the middle of the scene, and whose authority seemed to weigh with the ehiefs, that mischief was averted. I promised the chiefs that I would report their grievances to you, and that you would at a future dite come and settle the palaver, and eventually the men were disbanded. . . . I think that undoubtedly the real reason of the whole thing is that the people refuse to pay the House Tax, and were determined to fight rather than do so ...."

The District Commissioner', while travelling, held a large meting at Mawfé. In an mofficial report to the Governor, dated January 10, 1898, he wrote: "To-day week, 3rd inst., I held a large neeting of influential chiefs of Boompe, Tikonko, Bongai, Tihun, Mattru, Lubu country, and nany minor towns.

\footnotetext{
The local bame given to the West African Frontier Force.
} 
I gave them a long harangne, and talked quietly and softly to them. They all pleaded extreme porerty and want of boys, which, of course, is absurd. I told them 'All right,' but that they must try and do something, howerer little, just to let you see that they were willing, and gave them until to-day to bring in what they could. To-day they all assembled in Comrt (this was at Mawfé) and repeated the same thing; any wavering or further time would have been fatal, so I arrested the four prineipal ehiefs, Berri of Bungeh, Thomas Bongo of the Lubu comtry, Baha, representing Boompé territory and chief of this town, and chief Betsygai's representative. They held several meetings during last week, where I had spies, and they all agreed not to pay or attempt to pay for their own comntry. To-day at the meeting there were between 4,000 and 5,000 men. After arresting the chicfs, I dispersed the crowd, and assembled them in an open space ontside the torm. I stayed with them about an hour, taking things very quietly, and walking amongst them, as the slightest wavering or halfheartedness wonld have acted like a spark, althongh, of course, I was fully prepared; but I am glad of a bloodless result. At the same sime, I regret to say, I am not one inch nearer the collecting of the tax. . . ."

Threatening as matters appearel to have become, no danger of any moment was anticipated. Abunt a week after my retum to Bandajuma I again went on tax collection duty, this time to the small Boum eountry. I took with me on this trip a corporal and twenty-three privates as esert, with a few carriers and the necessary stores. The behariour of the people in the different towns and villages which I visited was precisely the same as on the former oecasion. Many scuttled off like rabbits at the first appearance of our party, whilst those who remained were snllen and unfriendly. I next went down to Mawfe, on the Boum River, where I stayed for three days at the honse of Mr. Allen, an edncated Sierra Leonean, who kindly oflerel to ynt ne up. Allen had lived for orer twenty 
years amongst these people, and had always treated them well and kindly. On saying guodbye to hin it was little I thought that it would be for the last time, or that only a few days later Mawfé would be the scene of a terrible struggle and wholesale massacre. The "fictory" here was gallantly defended, as will be hereafter described, by a screeant and nine privates of the Frontier Force, every one of whom was killed. Mr. Allen hinself was taken prisuner by the Boonpé, one of the most savage, cruel, and warlike of the Mendi tribes inhabiting this territory, and one of the originators of the rising. He was taken to boompe town, where he was brutally murdered by degrees -in fact, tortured to death.

On leaving Mawfé I marched down to the Jong country to a town called Kambia, sitnated on the Small Boom Pirer. Here I stayed for some days in the house of a large merchant, named Macaulay, who is a Justice of the Peace, and possessed a very charming and well-situated bungalow.

Considering the nature of the events to follow, it may be as well to gire in this place a short description of Kambia and of the factory enclosure in which we were staying.

Kimbia is sitnited, then, in the centre of the Jong country. This territory is of considerable area, and was formerly ruled over by an old woman named Betsy Gai, thongh where the lady acquired her very English-sounding patronymie I am quite muable to say. She died shortly after the rising, and was immediately succeeded by her daughter. In nuy time the headquarters of the town were at Tiboom. Now they are at Nattru, on the Jong River, about seven niles from Kambia. The natives were, it should be stated, originally all pure Sherbro; but the Inendis from the interior cane down in great numbers to mix with the Sherbro folk, and intermarriages between the two tribes have resulted in a population half Sherbro, half Mendi-at most undesirable intermixture on all accomnts, the warlike characteristics of the one nation being grafted on to the cumning of the other. The whole of this 
Jong comtry, from the Bullom right away down to the Lower Kittam and the Boompé, formed the very vortex of the rising.

The two towns of Old and New Kambia lie on either side of Kambia factory, Old Kambia being quite close and almost upon the "fictury" -- the honses approaching to within twenty yards of it - while Ner Kambia was situated some two hundred and fifty yards away on the other side. 'The factory itself consisted of a bmgalow forming one sile of a square, with a range of store-rooms and onthonses on the other two, the river occupying the fourth side. Surrounding the house was a fence of wire and wood, with a small coffec plantation beyond. Ontside of that the impenetrable bush commeneed, throngh which three roads converged on the town. 
"Plot me no plots, petition me no petitions."

Beiumont and Fletcher.

$\mathrm{W}^{\mathrm{E}}$

must now go back to the time when Major Tarhet, accompanied by one oflicer and all the arailable Frontiers, lurriedly left Freetown for Port Lolko mor special orlers from the Gorernor of the Colony to effect the arrest of a certain Timini chief. This worthy hat openly defied the District Commissioner hy returning to him unopened a letter he latd sent him, accompanied by a "contemptnons and defiant message." Karene was one of the districts in which the new Honse Tax was to come into force on the 1st of Jamnary, and the officials had been hard at work endeavouring, with no rery great success indeed, to obtain payment, or part payment, of the same from the Timini people. The refractory chief whom the Government wished to bring to book was one Bai Bureh, who rulel over the Kassi country. Bureh, besides being a man of acnte intelligence, was a renowned and successful leader, whose warlike influence extended not only to the confines of lis own lingdom, but to those of sereral adjacent native tribes. The Bai, or Kabalai, as he is sometimes called, must have heen perfectly familiar with European methods of bush-fighting, having seen service 
as an ally of the English in the Tambai campaign of 1892. His military qualities had been further proved when, in 1873-76, in his eapacity as commander of the Timini army, he inflicted severe defeat upon the Susus, and at the same time firmly established his reputation as a tactician of sorts. His name was now a honsehold word for miles aromd, and in many a village the mothers stilled their crying babies by whispering the name of this redoubtable Ethopian into their infant ears. This was the man who successfully defied the power of Great Britain for many months together, and thereby made for himself a name that will never die so long as the brave but misguided people whom he led remain a nation.

Many were the stories of this personage which I heard from my servant Fodi, himself a pure-bred Timini, who had acted as gun and spear-carricr to this ehief in his campaigns and raids after plunder into the Mendi conntry. He would tell me how Bai Bmreh nsed to dive into the river, and "lib dere for two day"; how at his word, many thonsand warriors would spring to arms; and low no ling or ehief, however strong, however warlike, eonld stand a single moment against lis fieree onslanght.

Even after derlncting a considerable discomnt from these enthusiastic statements, it was abumdantly plain that he was no ordinary man. And yet the cmivus thing abont it was that Burch was not born to leadership, was not even of chiefly rank. It was entirely throngh his own ability for war that he rose to be commander. We were soon to have witness of those qualities, as well as of the lravery, loyalty, and absolnte confidence in his leadership which his daring followers possessed.

And if Jureh was an musually smart man, so did the Timini prove to be in the events that followed. Savages they might be, but even in their very fighting they betrayed such admirable qualities as are not always to be fomnd in the troops of the "civilised" nations. 'They loved their chief, 
and remained loyal to him to the very last, whilst they " understand bush-fighting as well as you and I do our very alphabet!"

Almost part and pareel of the forest that surrounded them, they wore cmincutly adapted to the peculiar conditions of beal warfare. They rednired no elothes, and were hampered ly no transport. Their food was hidelen in the bush itsclf, where also they spent the night as comfortably as we should do in a palatial hotel. Altogether I must confess, after a somewhat intimate aequaintance with him, to laving a very great respect as well as admiration for the Timini. As Mr. Rudyard Kipling has it, "Ile's a poor benighted 'eathen, but a first-class fighting man.,"

Prior to the departure of Major Tarbet and his force, the Commissioner officially reported to the Governor the difficulties which he was experiencing in the collection of the Tax. As the despateh in question affords a clear idea of the state of things in the district at this time, I give it in full :--

"From the District Commissioner, Karene District, to the Hononrable the Colonial Secretary, Freetown.

"I hive the honour to report for the information of His Excellency the Governor some of the diffienlties I have met with in starting to eollect the Honse Tax, with suggestions I would submit for His Excelleney's consideration.

"Port Lokko being one of the strongest and wealthiest centres of my district, I decided to commence collecting the Hut Tax from this place, and accordingly left Karene with Sub-Inspector Crowther and ten Frontiers last Friday, the 4 th inst., arriving there the following day. Since then, continued threats and rumours of attacks have been received, chiefly from Bai Bureh. As soon as he heard that we were leaving Karene he imagined we were going to arrest him, and at onee collected war-boys and threatened to attack us. At midnight on the same day I received the report from the 
Seeretary of Native Affairs to investigate rumour of report that Bai Bureh was collecting arms, \&e., from the Freneh. A rumour reached Karene that Bai Bureh had heard that we were coming to arrest him, and was, in consequence, coming in to Karene that night to attack Brima sanda, and that he was determined to resist any assistanee the garrison at Karene gave to Brima Sanda. I did not believe this, but the next morning I sent out spies to watch Bai Burch, to report on what he was doing, what arms and ammunition he had, how many brech-loaders, and whether he was in communication with the French, \&c. I left Karene that day, and on the way to Port Lokko met two missionaries who had eome to warn me 'that there was a plot against my life and that Bai Bureh was going to shoot me shonld I attempt to arrest him.' The same day a letter was sent to Sub-Inspector Crowther at Kabantama in the same strain [eopy attached]. We lialted at Romani for the night, throughout which nessenger's were coming and going from Bai Bureh watehing our movements.

"On arriving at Port Lokko next day (Eth) I saw all the Sierra Leoneans, and ealled upon them to pay their tax. They seemed willing but afraid, as the chief and natives had said that the first to pay the Tax wonld be murdered. They were willing to pay through their landlords or direct to me, if the chief would undertake that they shonld not be molested. This he refused to do, and was detained in eustorly and warned that lie would be given until Monday for his final answer. The Sierra Leoneans were also told to attend anain on Monday moning and be prepared to pay. On the following night, Sunday, about midnight, a report reacherl us that many people were coming into the town, hearing that the chief was a prisoner, with the intention of resening him. Finding that there was more or less truth in the report, I placed ontposts romel our quarters, where the clicf was, and brought down all the ammunition from the baratcks in the town. The town was very disturbed all night, and of conrse 
we had to remain un and on the alert. On Monday, the 7 th, we found that one of the sub-chiefs, Santiggi Kearah, had summoned Bai Bureh's people to come and rescue Chief Bokari Bamp. I then summoned all the sub-chiefs and headmen, and after allowing them to consult with the chief, they were called npon to gire their answers as to whether they wonld modertake not to molest the traders for paying their taxes. After a good deal of coaxing they were at last persuaded to give a very half-hearted consent, though it was erident that not much faith could be placed in their word. But the traders were now thoroughly frightened of the natives, and refnsed point blank to pay their tax, either to me or through their landlords. I had a private interriew with the chief that same afternoon, and persuaded him that he was rmuning a great risk, and would be arrester if he did not gnarantee that those who paid their taxes would not be nolested. On Tussday, the Sth, all the traders were brought up and charged lefore me with refusing to pay their tax. They used every means within their power to annoy and hinder me. Several of the men pretended that they conld only speak 'Aku,' knowing I had no interpreter for' that language. The women simply jeered at me as each was brought up for judgment. They were detained as their goods were heing distrained on, but it was found that they had removed all their raluables, and as each bundle of worthless rubbish was bronght in from their homes, it was greeted with jeers by all the female traders. All were fined with the option of imprisonment. One trader was sent to his home for money to pay the fine, but his messenger was stopped by one of the healmen, who took the money from him and threatened to kill the man if he paid the fine. As matters were now getting serious, I summoned the chicf, but he failed to come. On Wednesday, the $9 t h$, the chicf came down with all his sub-chiefs, and about 1,000 followers. I then told them my patience was well-nigh exhausted, and I called upon them for 
an immediate answer to these questions: (1) In the event of the Sierra Leoneans paying their tax, would he instruet all his people not to molest them? (2) Would he start at once to collect the tax from the natives? To both of these questions he answered 'No!' I thon arrested the chief, and four of the ring-leaters, as follows:--Bokari Bamp, acting chief, too weak to rule his people properly or to assist the Government against opposition, and easily led astray by bad advice from his Surtignis, ${ }^{*}$ of whom he is thoroughly frightened. Would be a loyal chief if he dared, when not subject to Bai Burch's influcnce and that of his Santiggis. (Twelve months' imprisonment. Hard labour.) Bai Salamansa, a very dangerous man, with many followers, who buasts that he can defy the Government and resist the law, and who has threatened that the first one that pays shall be murdered. It was he who prevented a tratur from paying his fine and threatened to burn his honse. (Fifteen montls' imprisonment. Harl labonr.) Santiggi Kearah, an equally dangerous man. In leagne with Bai Bureh to resist the 'Iax by force, and a man with many followers. It was he who bronght in Bai Burch's people to rescue the chief from custody. (Fifteen months' imprisonment. Harl labour.) Ansmmani Bali, a powerful and dangerons man. An open enemy of the Government, who is determined to resist the Tax. It was he who resencd Bai Foki when he was arrested and attacked the police. ('Twelve months' imprisomment. Hard labour.) Alphat Saidov, a dangerons man whom I have previonsly had to summon to Kannia and caution. It was he who sent a messaige to the Sanda people that they were to take no notice of Brima Samda's election by the Govermment, ats he would linnself cone and "pull 'a chicf. ('Twelve months' imprisonment. Lard labour.)

"As the tide had reached high water half an hour since, and as I knew the risk there would be in keeping these prisoners till the next tide, about midnight (with over 2,000 
people ontside in the town watching the turn of events) I deeided the safest way was to send them to Freetown Gaol at once, which I did under escort. Hence the reason why no report accompanied them, as time would not permit. This cleared the air considerably, as the Sierra Leoneans not only volunteered to pay their Tax at once, but expressed their regret at having defied the law. Being their first offenee, they wore let off with fines, which were piaid at once (amounting to about $\mathfrak{E} 70$ ), and their distrained goods were then restored to them.

"On Thurslay, 10th, I sent for the headmen in the town, and gave them a long interview, telling them to take warning from the erents of the last two days. I elected Sorie Bonkay as acting chief until either Bokari Bamp's release, or until a new chicf had been elceted, subject to approval. He was then instructed to start collecting the tax at once, and the Santiggis and other's told to support him. This he is very pluckily doing, in spite of threats of murder, attack, and arson. Considering the very diffieult position he is placed in, he has proved himself very firm and loyal. During the middle of the night he came to me in a very excited state, saying that a messenger had just arrived saying that Bai Bureh was coming in that night to attack him for collecting the Hut Tax. I again took every precantion by placing ontposts all round, and remianed up all night. I also gave him a small gnard, which he herged for, and who, during the night, eanght three men coming in with alms secreted, which were seized. I think they were sent in by Bai Bureh, as a sort of advancel guard, though I cammot tell for certain. Throughout the night the people of Port Lokko took fright, and removed in canoes, and by roal, to the neighbouring faliais, with all their property, fearing Bai Bureh would come in and attack the town and bum it. On Friday, the 11 th, the acting chicf still continued perseveringly to eollect the Hut Tax from the few people who remained, and he has 
now sent round to all those who have removed that, if they do not return within 24 hours, they will be fined. I am of opinion that the fear of an attack by Bai Burch has more inflnence with them than the fear of a fine. I feel certain that the town and Lokko country will not settle down until Bai Bureh's influence is removed. As the Sierra Leoneans and natives who have paid the tax have been threatened with attack, murder, \&c., I feel it would not be right to return to Karene until they have nothing more to fear. Neanwhile, some of the spies I sent to Bai Bureh's country have come in. They report that Bai Bureh fears and expects arrest, which he will probably resist, thongh my only fear is he will evalle arrest, as he did before, by hiding. Accordingly, I have sent to summon him to collect his tax at once, and be preprured to pay me when I visit him, shortly. I feel certain he will refuse, perhaps defiantly, and I shall then take steps to effect his immediate eapture. Until this is done, there will be no peace in the country, and the tax will never be collected with success. But when once it is done, Port Lokko will paly up en masse, and the other large towns of Mange, Kimbia, Kukuna, Mabile, \&e, will follow its cximple. The effect of the fine on the Sicrra Leoneans here has already reached other large towns, and I hear the Sicrra Leoneans there will not resist. I hear also that the natives of these towns are all in awe of Bai Burch, and when he pays, or is removed, they will pay withont the least difficulty. Though my sentenees on the acting chief and four headmen sent down appear severe at first sight, it was absolutely necessary, ats an eximple to others, and will lighten $m y$ difficulties consideral,ly. But I intend to ask his Excellency to release Bokari Bann as soon as the commtry is ciniet, and the tax is collected. At the sume time, I whall submit to his Execllency low very drsirathe it is, for finture peace, that, of the other four arrested, two, at least, be deported and not allowed to retnu, viz., Bai Salamansa and Sintirgi Keareh. 
I would add, also, how very desirable it is that I do not return to Karene mitil peace is restored, and Port Lokko has paid the whole tax. If once I do this, the news will spread that I have had to acknowledge that I have failed to collect the tax, and other chiefs who are inclined to resist, such as Bai Foki, Pa Kobblo, \&e, will cause entless trouble. A clean slate means easy success. The abore report, perhaps needlessly lengthy, and too full of details, I have written as the shortest means of giving his Excellency a clear idea of the state of things. I have no fear of cventual suecess, but I an very anxions to be allowed to give my attention only to this matter, until I lave male a fair start, in spite of Treasmy returns being delayed for a week or two this month. To stm np-I wonld ask his Excellency's approval to: (a) Sentences passed on five prisoners sent down. (b) Bokari Banp to be restored as Acting Clief, so soon as the tax is prid, and order restored. (c) Bai Salamansa and Santiggi Keareh not to be allowed to retmm, as most dangerous to good order. (d) Sorie Bonkay"s appointinent as Acting Chief for the present to be confirmerl. (b) My remaining here till Port Lokko has paid the tax, and order is restured, though this may mean a slight delay in rendering monthly returns and vonchers, le. $(f)$ The loan of about 20 Frontiers (not recruits) to effect Bai Bureh's arrest. The Customs, French Frontier Licence, and Ont-station duties make it impossible to bring in men from out-stations, at which there are abont sixty men. I am told that some of the men now with me had only been joined two weeks when they were sent up. Consequently they can have done no musketry. There must he at least twenty left at Karene (for staff and guard duties, \&c.), and this would only leare abont fifteen men for arrest purposes. Bai Bureh can only be arrested by sereral parties approaching firom different flanks, or he will be sure to escape. I wonld therefore ask for twenty good men at least, at once, so as not to risk failure.

“Pont Lohizo, 12/2/98. 


\section{CHAPTER VII}

THE TIUINI RISING

"Not one cent for tribute."

$\mathrm{O}^{\mathrm{N}}$ the arrival of Major Tarbet at Port Lokko, it was reported that the refiactory chief, Bai Bureh, was at a place called Maliera, some two honrs' march from Romeni; and a few days later he set ont with a force of $4 f$ men and one officer, with the District Commissioner, to Romalia, on the Karene roar, where he lalted for the night. The next morning they went straight to Romeni, which they found descrted, though the forest aromed was described as being "full of war-boys." Immediately the small foree was halted and formed into splare, while the baggage train, originally intended to go on to Kabantama, was also halted, as, under the present small eseort, it would be quite impossible to get it through.

The spies of the British forec had meanwhile reported Bai Burch to be in the immediate vieinity, and althourh no powder hat as yet been burned, the aspect of affiniss was " most threatening," and "stoncs were heing thown." On the advaner of the force, the war-buys concouled in the smroumling hush began at onee to follow and quickly dosed round one llanks; in fact, onr force was gradually, lut certainly, heing surromded on all sides.

An attempt was made to stop this threatening morement 
by the discharge of a few volleys, which were immediately returned by the concealed enemy. Several of the carriers now threw down their loads, while others were attacked by the enemy, and their loads captured. Others, again, of the porters, having had their loads seized, were themselves made prisoners and carried off.

On arriving at Kabantama, it was reported that the road between that place and the river was full of the enemy, who agrain opened fire on the columm from a place called Nasumbala, and when erossing the river the rearguard was also fired upon and forced to retreat. After a long, weary march, the party arrived at Karene at 5 p.m. We were now informed that the whole of the Kassi country was in a state of open revolt, and the entire male population armed and in ambush in the forests, while the road to Port Lokko was dangerous for messengers and small parties. Moreover, it was reported that the Great Scarcies chiefs had sent many fighting men to help Bai Bureh; so that altogether the Britisl force was in a very precarious position. I afterwards ascertained that some of the chiefs in the Koina-Dugn district had alsu sent some of their war-boys to assist the Timinis.

Although the Koina-Dugn district did not rise, the Commissioner, Captain C. E. Birch, oecupied a perilous position at the headquarters, Falaba. Quite eut off from civilisation (he was 250 miles from Freetown) Captain Birch lived in close proximity to the wild hill tribes and with him were very few men.

On the withdrawal of the party to Karene, as ietailed above, it was practically made prisoner there, for a return either to Freetown or Port Loklio was now equally an impossibility.

This nnsuccessful attempt to catch the Timini chiefs was the forermmer of large operations carried on throughont the Karene comtry, and indirectly nearly the whole Sierra 



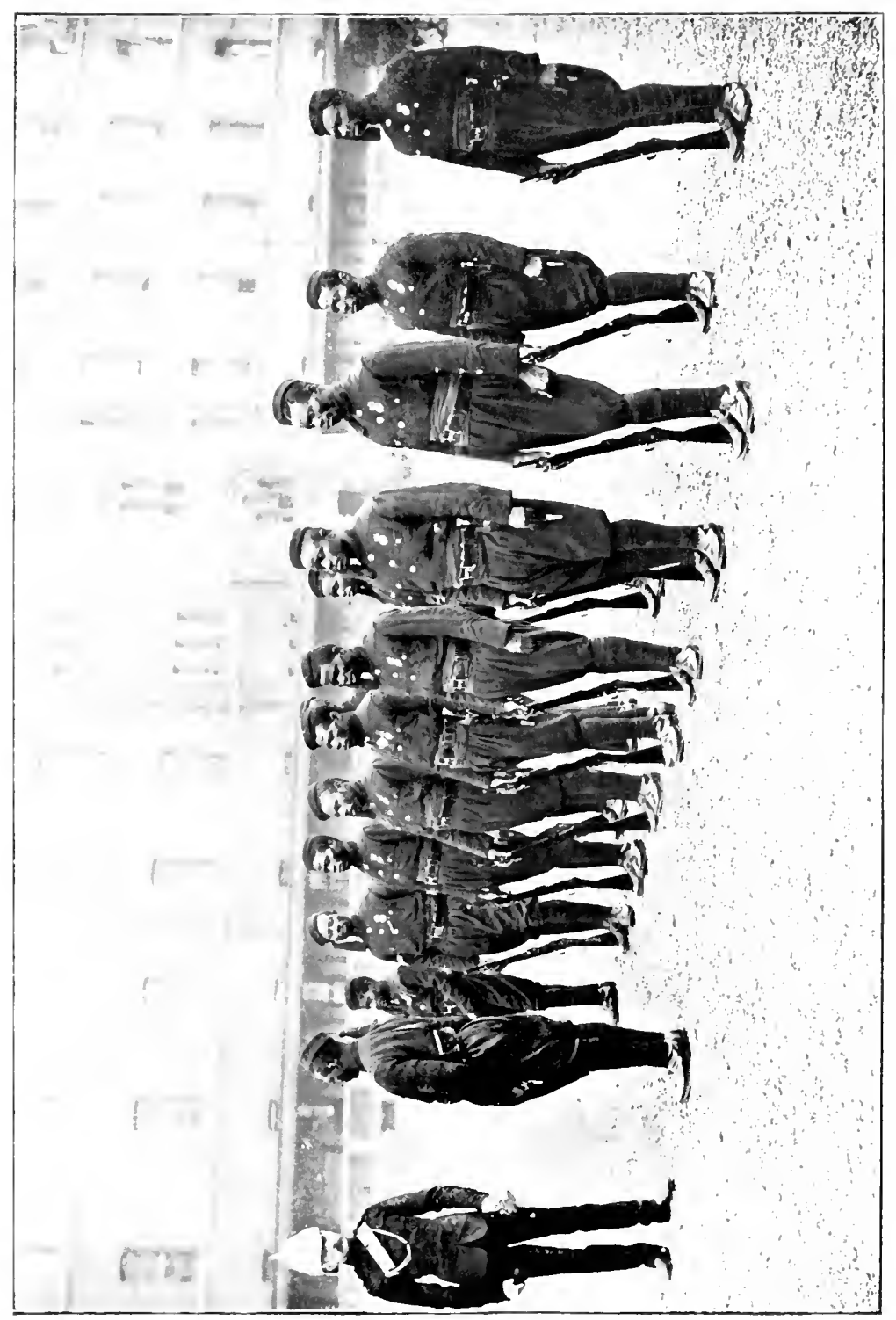


Leone Hinterland,-operations which cost many hundreds of valuable lives, involved the destruction of thonsands of pounds' worth of property, and brought down untold misery and suffering upon many imocent heads. Many of the engagements which followed were exceedingly severe, the British usmally being opposed to vastly superior numbers. The operations were, in fact, describei by Colonel Narshall as involving "sone of the most stubbom fighting that has been seen in West Africa," whilst " no such contimnity of opposition had at any previuns time been experienced on this part of the coast."

During the next two weeks incessant fighting took place between our small force and the enemy, our object being to prevent them crossing the Mabole Piver, and thereby completely surromnding the Karene barracks. On the 24th of Febrnary 150 men of the West India Regiment, with a 7-ponnder and Maxim, under the command of Major Norris, D.S.O., started from Freetown, by a circuitous route through Pobarton, with the object of assisting in the capture of Bai Bureh, and strengthening the garrison if hard pressed. With this force came fifty carriers, carrying food supply for thirty days and camp equipment.

On arriving at Karene, on the 28th of February, Major Norris fonnd the place invested on all sides, and the hospital alrearly containing several wounded. The government was now made over to the military, and on the 2nd of March martial law was proclaimed. One of the most inportant steps to be taken in the first instance was to maintain communication with Freetown, and on the 3rd of March the West India detachment marched to Port Lokko with this olject.

From the moment the British foree showed itself ontside the barracks mutil the time of its arrival at Port Lokko, it was boldly and recklessly attacked. Cilptain scott, R.A.M.C., and four men of the West India Reginent and five carriers 
were severely wounded, and Captain Fannce, two privates, and seven earriers slightly wounded. The encmy suffered no small loss during their attacks. On the arrival of the column at Port Lokko, more troops were requisitioned for by carrier pigeon. Our men were afraid of an attack on the place, and had stockaded themselves in front of the Mission House. On the 5th of March another 100 men of the 1st West India Regiment amived at Port Loklio under the command of Major Stansficld. Our laager here was attacked at dawn, but being expected, the enemy was repulsed by 8 a.m., and again suffered severely throngh their reckless exposme. Sniping continued for the whole of this day. On the arrival of H.M.S. Alecto with the additional troops, they at once began to shell old Port Lokko, but withont apparently much resnlt. A further urgent message was sent for still more troops, and meanwhile on the 9th of March Karene was again attacked, and the encmy repulsed after a hot engagement of two hours. Nothing further occurred, with the exception of the enemy firing the bush, during the march of Major Stansfield's company to Karene, until the 9th, when 50 men of the West African Picgiment with a 7-pounder gun, and 215 lahourers and supplies, arrived under Major Donovan, A.S.C. The District Commissioner, witil an escort of 100 non-commissioned officers and men of the West African Regiment and Frontier Force, also now arrived at Purt Lokko, having been attacked at a place called Malal, where five men of the Frontier Force and three carriers were severely wounded. The District Commissioner lad gone to Port Lokko with the idea of acting as political adviser to the officer commanding the troops there.

On the 11th of March another company (120 strong) under the command of Major Bourke, D.S.O., arrived at Port Lokko, together with 100 labourers. This company, with that of Major Stansficld, was instructed to act as a flying column around Karene. A place called Rogabold was ordered to be 
destroyed, and a reward of $£ 50$ was offered for the apprehension of Bai Bureh.

During the night of the 17th of Narch sniping by the enemy took place at Karene. The next day Major Stansfield, with 100 men and a Maxim gm, left for Roharton with the idea of recovering some stores he had been obliged to leave behind owing to a lack of carriers on his former jommey to Port Lokko. This column came into action at Simhon, am hat severe fighting again at Mabolunto, which resulted in Lientenant Feld being killed, and eight non-commissioned officers and men and 16 porters severely wounded. Owing to the opposition here the colnmm was compelled to return to Karene. Another 125 men of the 1st Battalion West India Regiment and 312 labourers, mider the late Colonel Bosworth, had meantime arrived at Port Lokko. This force was opposed at Matatin and Mamalari, resulting in eight privites of the West India Regiment and Frontier Force being wonnded.

And now the fighting aronnd Port Lokko and Karene became general. Whenerer a British force was seen it was immediately attadied. It mas impossible to get at the eneny during a march throngh a nitrrow bush path, never nore than three to six feet broad, both sides lined with an inrisible foe largely armed with hreechlouding rifles, and completely eoncenled in the dense forest.

A company of the West India Reginent and fifty men of the Frontier Fure set ont from Port Lolko for Karene on the aznd of Matrch, under Ciptain Carr-Smith, with the object of transferring some of the carriers who were stationed at the latter, to the former place. The force was allowed to proceed mmolested nutil it reached a village called Matiti, where it came face to face with several emmingly placed and strongly defended stockades. At the end of an engirgement lasting five honus, during which the bayonet and sword were freely used, the cohmm got through, Lientenants Craig-Brown 
and Lawrenson, and fifteen privates being severely wounded, in aldition to several porters killed and thirty-five womded, while a quintity of stores had also been seized by the eneniy. Owing to this opposition our force was obliged to bivonac at Maperri and proceeded next diny to Karene.

Three days later the colmnn, laving secured its olject, nanely, the bringing away of the carriers-800 in muluer-set ont on its retmrn. No somer had it reached Matiti than it was again rigorously attacked, and, the path being particularly narrow and winding at this part, alunost surronnded. Further on, at Mamaliki, the enemy attempted to msh us, but were again repulsed with loss. At Matiti we were met by a perfect hail of bullets and were forced to take alvantage of any serap of cover in order to return the fire of the enemy, who, although absolutely invisible, were always within fifty y:urds of them, securely hidden in the thick modergrowth and "as thick as bees." Here Captain Carr-Smith and Lientenant M'Lean were both severcly womnded, and four privates of the West India Regiment killed, and six severely wounded, while four non-commissioned officers and men of the West India Regiment were slightly wounded. All the combatant oflicers now being wounded, the colmm had to fall back anain on Karene, and at a point where there was the greatest danger of being rushed. However, owing to the gallant behaviour of the non-commissioned oflicers and men of the West India Regiment, Karene was reached without any further mishap.

On this day also Major Bourke, D.S.O., with 150 noncommissioned officer's and men of the West India Regiment and the Frontier Force, marched to attack a town called Barmot, situated some ten miles distant in a north-easterly direction from Karene. 'This attack was snecessful, the enemy being taken completely by surprise; it resulted in the town being burnt, and the enemy driven from their stockades. 'The next day the news of the reverse which Captain Carr- 
Sunith had suffered reached Colonel Bosworth, and he decided to march at once to Karene, to clear the road if possible of all opposition. He took with him 100 specially picked men of the 1st West India Regiment, who marehed with as little impedimenta as possible, and four officers. On reaching Malai the invisible enemy poured in a hot fire from the front and both flanks, and our force, having expended humdreds of rounds of ammunition, reached Romeni, where they were met by further fire at point blank range. Hastily pushing on to Kagbantama serious opposition was again met with, the enemy pouring in a perfect hail of lead from the town, which was strongly fortified and loopholed. By this time our troops were becoming jaded and fatigued by so much marching and incessant fighting in the great heat. Howcver, they gallantly responded to the further call made upon them, and the enemy were cleared out at the point of the bayonet, our fellows charging in grand style up to the very muzzles of the rifles.

At this juncture Colonel Bosworth succumbed to the intense heat, the command devolving upon Major Donovan, A.S.C. The gallant Colonel died at $6.30 \mathrm{p} . \mathrm{m}$. the same day, but not before he had received news of the complete rout of the enemy. The column now pushed on to Matiti, where they found themselves again confronted by immense stockades erected on either side of the road. Matters were now looking extremely ugly. The commanding officer was dead, many of our neen were either killed, wounded, or next to useless from overwhelming fatigne, and, to add to our other troubles, the rapid darkness of the tropical night was coming on. The carriers also gave the column a lot of trouble, while the enemy, no doubt secing their advantage, continued to attack us with renewed ardour. Indeed, these night attacks are just the kind of fighting that the Timinis like best, and now the game seemed to be all in their hands. It was at this time when Captain M'Donald was shot dead while gallantly leading his 
men against a stockade, and thirty more non-commissioned officers and men of the West India Regiment were also killed. Having, however, eventually turned the obstruction and cleared out the enemy, who immediately re-collected in great numbers in the surromnding bush, the column proceeded on its way through the pitchy larkness along the narrow winding path, at every end and turn of which the Timinis were posted.

Utterly fagged ont, the column reached Karene at 2.30 a.m. on March 28th, the force being nigh at breaking strain when it marched wearily into this fortified position. We may well congratulate oursclves that no more serious disaster overtook us during this march in the inky blackness. Had the enemy charged us during our attacks on their stockades, or made a continued rush, there is not the slightest doubt that we should have been amnililated. Surrounded as we were by great numbers nothing could have saved us, and it is only by the merey of Providence and the luck which so often falls to the lot of the British arms on these occasions that any of us came through alive.

The next day Major Bourke, with seventy non-commissioned officers and men of the 1st West India Regiment, patrolled the road up to Maperri, and took several stockades at a loss of six privates of the West India Regiment wounded, and three carriers killed. On the 28th of March, Major Tarbet also patrolled the road to Matiti, and succeeded in destroying some half-built stockades. On March 30th Major Bourke, D.S.O., arrived at Port Lokko with 120 men of the West India Regiment.

There were now twelve wounded officers and men at Karene and 800 carriers, namely, those who had been driven back under Captain Carr-Smith in the fight on the 25th. Accordingly Major Donovan, A.S.C., with 200 men of the West India Regiment, 800 carriers, one Maxim gum, and the sick and wounded, marched out from Karene on the 30th, seventyfive of the 1st West India Regiment, under Major Bourke, 
forming the advanced guard. More sharp fighting ensued, and no fewer than five of the enemy's stockades were taken and destroyed, at a cost of Lientenant Jones and six privates severely wounded. These actions cleared the way so far for Donovan's columm, which was barred, howerer, at Mamaliki by three strong stockades. Here a murderous fire was opened on us, our fellows lying down for cover while the enemy's slugs and bullets sang like harp-strings overhead. Colonel Johnson was amongst the number severely wounded here, and this gallant officer died two days afterwards. Many carriers were also killed and wounded, mainly owing to the fact that as soon as the enemy opened fire numbers of them would at once lose their heads, fling down their loads, and run about in all directions.

We halted at Magbantama for the night, but owing to the incessant sniping that went on there was little sleep for anybody. We had now several wounded on our hands, and the advance party shortly returned to report that between us and Port Lokko many stockades had been built, and that both sides of the ruad were lined with the enemy, who were lying in ambush in readiness to receive us. To have attempted to run the gamntlet of stockades against which a 7 -pounder gun had no effect whatever would have simply meant the killing of 70 per cent. at least of our force, while, judring from previous eneounters, every officer would have been almost certain to be hit.

Major Donovan therefore eut a path through the bush with much labour and difficulty and arrived at Port Lokko at 9 p.m. on Mareh 31st, not, however, withont encountering the ever-watchful enemy again at Mabomrani, which resulted in more casualties on our side.

Colonel Marshall arrived at Port Lokko on April 1st and took over the eommand of the forces from that date.

The situation in the Kassi comntry was now gritve indeed. The hunted chief was no nearer being eanght than he was a 
the commencement of hostilities, while his warriors were in evidence everywhere. Taking into consideration the number of officers and men at present employed, our losses in killed and wounded had been high. On the other hand, so far as we could ascertain, the loss inflicted on the enemy was ridiculously small, in spite of the thousands of rounds of ammunition that were daily expended. Since February we had been actively engaged against an adversary whom we did not often see, but whom we knew could see us, and who shadowed our every movement. The nerves of the officers and men wcre severely shaken by this, one of the most trying modes of warfare, and the deadly climate, worse even than the enemy's bullets, was eating into the constitutions of Europeans and natives alike, who by this time, owing to the constant strain of sleepless nights, incessant fatigne, bad food, and severe heat, were in anything but a healthy and sound condition.

It is impossible to give in detail a record of the numerous and severe skirmishes which took place between onr troops and the warriors of Bai Bureh. Many gallant actions were, it is only fair to say, performed on both sides. In one a private of the West India Regiment was set upon by three armed warriors. He bayoneted one, shot the other, and kept the third at bay with the butt-end of his rifle until a comrade rushed up and shot his remaining adversary dead. On another occasion a wounded Timini chief was able with one hand to withstand the onslanght of a soldier and even to severely wound him, being himself eventually shot in a frantic effort to take the other's life.

Meanwhile, if our columms were not to be swept off the face of the earth, some other method of procedure must be adopted, and that quickly. The enemy's defence was so strong that already on one occasion it had taken our people several hours' incessant fighting to advance a little over thirty yards. Inside the Mission-honse at Port Lokko lay 


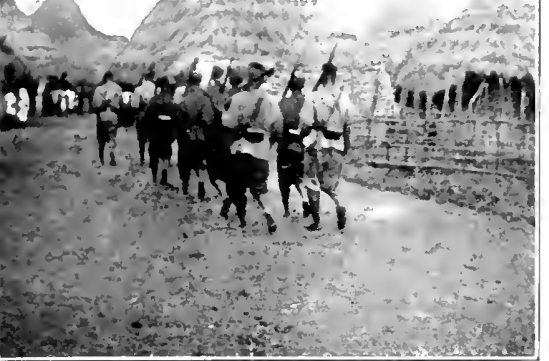

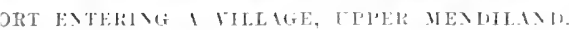

(P. : $: 3:$

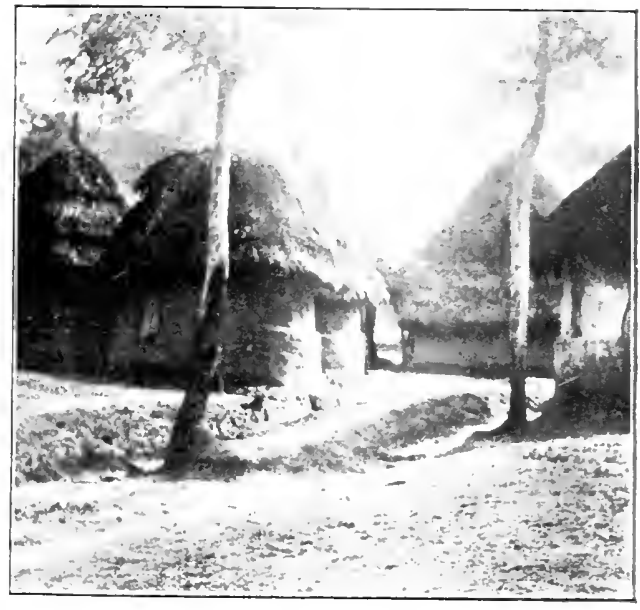

MVITI.

(P. 61.)

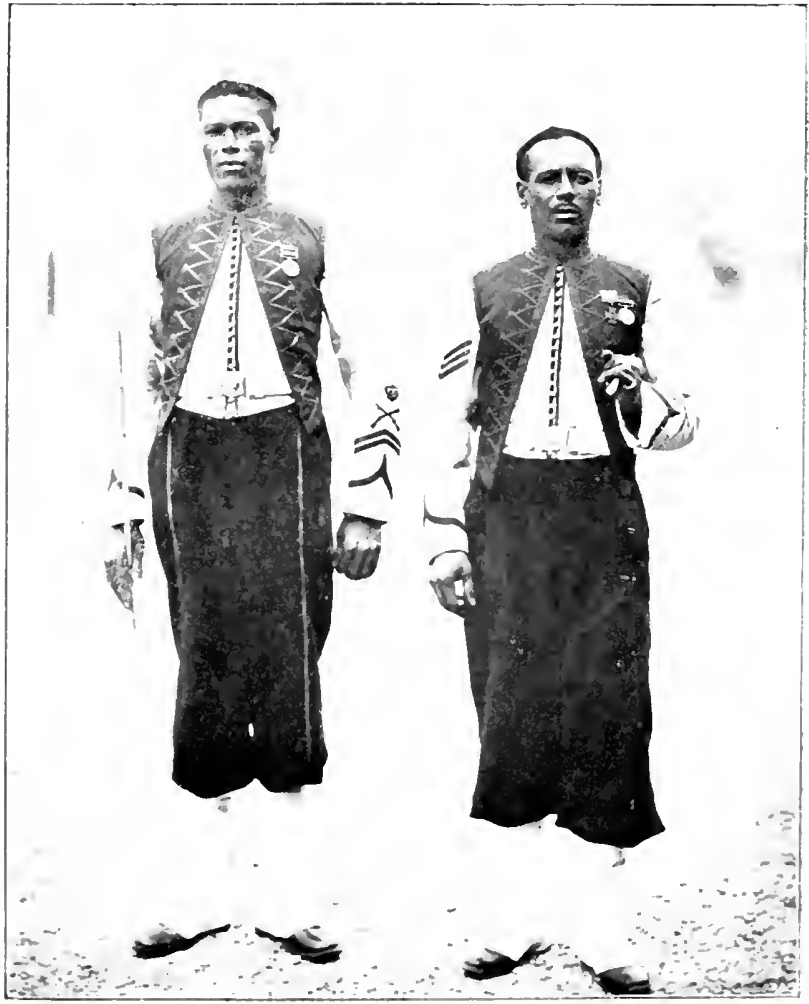

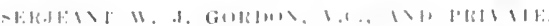

Whot India linginent 

200 sick and wounded, while the hospitals in Freetown, civil and military, contained no ferwer than $150 \mathrm{men}$, invalided from the scene of action, and before many months were over the list had totalled up to 600 killed and womded, including admissions to hospital from sickness, and carriers and others who were missing.

For some little time the gravity of the situation was scarcely realised at Headquarters on the Coast, though the following message, despatched from Port Lokko to Freetown by the officer commanding the troops in the Kassi country, must have given people some idea of it. The message ran as follows:- "Things very serious: fifty men of the West India Regiment and twenty-seven carriers missing, many wounded, including four officers. Lieutenant Yeld dead."

As I have already said Colonel Marshall arriced on the scene of action on April 1st and at once went earnestly into the state of affairs, and in lis report of the expedition lie stated at this point that "it was evident that the course hitherto adopted, viz., that of sending columns up from Port Lokko to Karene, could not be continued indefinitely without involving the sacrifice of the life of every officer of the battalion." He therefore decided to establish two intermediate posts, which would divide the distance between Port Lokko and Karene into shorter marches, and, by rendering the passage of the convoy to and fro more secure, thereby enable him to provision Karene the more easily. This would also serve at the same time to provide bases for the flying columm.

Prior to this, several blnejackets and marines had been landed from the Alecto and the Fox. More troops, chicfly belonging to another battalion of the West India Regiment, were meanwhile despateled from St. Helena, and an emergency detachment of Royal Aitillery and other details were sent ont from England. In addition, detachnents of Royal Engineers, Sierra Leone Royal Artillery, aul numbers of 
armed Court Messengers were sent into the Kassi country to assist in overpowering the hitherto invincible Bai Bureh, who up to this had certainly, as Tommy put it, "male things 'um a bit."

Major Bourke, with 120 non-commissioned officers and men of the West India Regiment, set ont with the express purpose of destroying the stockade at Mabkane, the place where Major Donovan was stopped on the 31st of March. This was satisfactorily accomplished with slight loss, the casualities being one European gumner wounded, and one private (West India Tiegiment) sererely womded.

All the senior officer's were either sick or wounded, so on the 3rd of April Major Donovan, A.S.C., Captain Morley, West India Regiment, and Captain Tyler, R.E., left Port Lokko with a force of 230 non-commissioned officers and men and provisions for Pomeni, a march of some thirteen miles, with the object of establishing a post there. The colımn then formed a laager. The next day Major Donovan and Captain Morley returned to Port Lokko with all the carriers, and Captain Stevens, of the 1st West India Regiment, was sent ont to replace him at Romeni. Two companies of the West India Regiment were sent to Roneni on the 7 th of April, and encamped there for the night; and on the following day set out in two parallel lines, one, on the main road, being mnder Colonel Marshall, and the other nnder Major Borrke. The column on the main road met with opposition, and eventually the enemy were driven out of their stockades, no less than twelve in number.

Major Donovan's column, missing its way somehow, had to return, and followed Colonel Marshall's force along the main road. An engagement took place at Rotifunk, where the enemy were repulsed by volleys supplemented by the fire of a 7-lb. gun. On our arrival at Kagbantama four nore stockades were taken and destroyed.

To Major Kirk, R.A., was entrusted the supervision of the lines of communication. Colonel Marshall, with a flying 
column, now set out along the Katenta and Mabele roads. The enemy were expected to be in force at Mabele, a position easy of defence whilst difficult to attack. Wide, deep ravines, lined with impenetrable bush, commanded the approach to this town, and in fact it was an ideal sitnation for the tactics of a lurking and cunning foe. As soon as the column appeared within sight of their town, the enemy opened a heavy fire, but were at length driven ont with loss. The convoy, which had set out for Karene, was also set upon at Matiti, and, after a severe fight, Major Donovan had to fall back upon Kagbantama. In this engagement two men of the West India Regiment and four carriers were killed, and four men and nine carriers slightly wounded. Captain Tyler, commanding the Royal Engineers, was also womnded.

Having got rid of his wounded, Major Donovan set out on his return mareh to Karene, and was this time unopposed.

On April 14th a small column, accompanied by Major Donovan, set ont with a view to inspect a site for a new camp. During their march the enemy attacked vigoronsly, and several more of their stockades were turned and taken. Some casualities occurred, including the severely wounding of Donovan's hammock-boy, who was found after the skirmish lying bleeding to death within five yards of a large stockade. On seeing his boy down, Donovan at once gallantly rim to his assistance under a perfect hail of bullets, but before he conld get him away he was himself shot down, and fell mortally wounded with his body riddled with shot. This was the list heroic deed of several which this gallant officer hat performed sinee his arrival on the seene of action. He had proved himself a capable leader and one of tireless energy, as well as a cheerful companion on the march and by the camp-fire. His death, met in the performance of an at of conspicuous bravery, was sincerely mourned by all, and indeed, when it was reported, cast a gloom over the whole of the British force. 
On this day Major Bourke attacked a strongly stockaded town called Winti, which he took at a small loss on our side, and on the 15th the flying colmm began to extend its radius of action. From this time onward the most severe fighting of the whole expedition took place, our force being constantly and entirely engaged from early morning until late at night. I cannot do better than quote here an extract from the despatches of the Officer Commanding the forces in the Kassi country to the Officer Commanding troops in West Africa, and dated August 9, 1898. The document in question runs:-

"From this date the fighting was continuons and the opposition constant. Stockades there were everywhere, twenty of these formidable structures being destroyed in one day. The flying column commenced to march at daybreak, and rarely birouacked before 5 p.m. Half an hour was allowed for breakfast whenever the attentions of the enemy dil not interfere, and a halt of $1 \frac{1}{2}$ hours was lnade during the milday heat. These were the only halts. The remainder of each day was ocenpied in marching and fighting; it was no uncommon thing to have four or five stnbborn fights during the day, whilst a day rarely passed without two or three." 


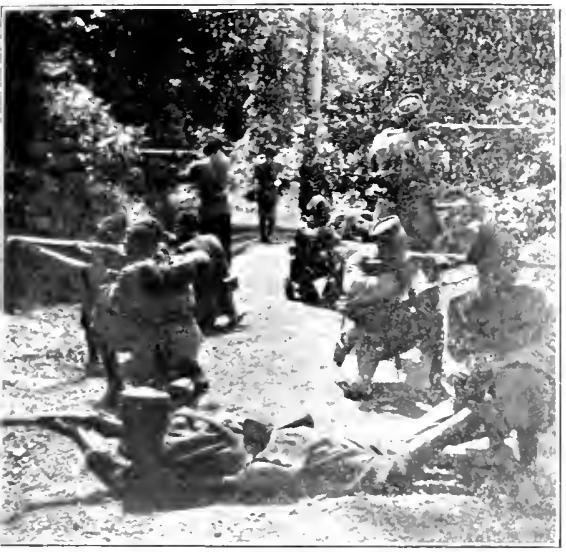

IX $11110 \mathrm{x}$.

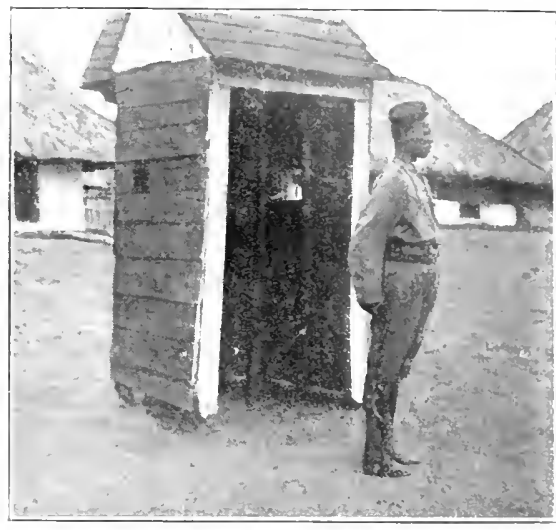

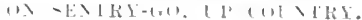

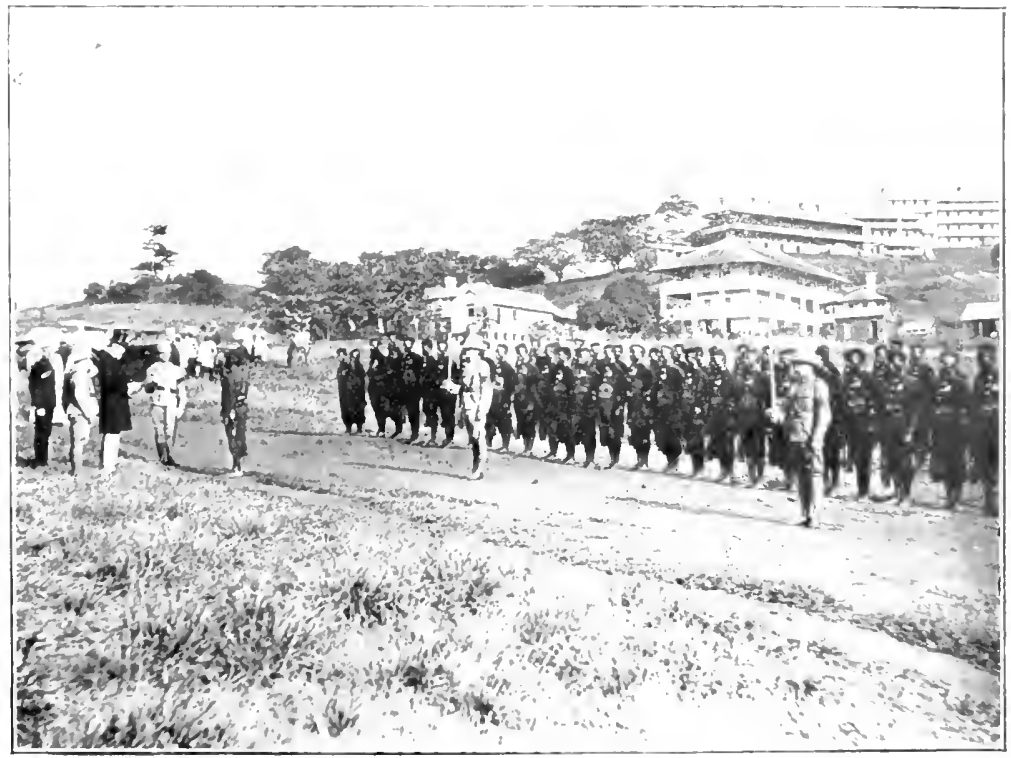

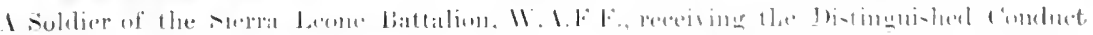

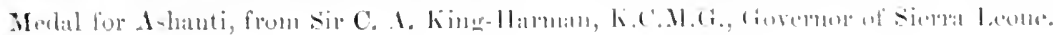





\title{
CHAPTER VIII
}

\author{
OPERATIONS IN THE THMNI COUNTRY
}

"To every man upon this earth

Death cometh soon or lute."

- Lays of Ancient Rome.

ALEVEN or twelve hours continuous marching in the enervating climate of the tropies, accompanied by poor food and bad water, would at any time be arduons enough; but it is ten times worse when these initial hardships are compled with continuous fighting conducted in the manner of this campaign. So long as the enemy stuck to their forests and lay concealed behind stockades and hidden amongst gigantic trees, it would take some considerable time before they were subdued. Meanwhile they could with ease and comparatively little risk to themselves continue to shoot down our men and pick off our officers, whenever they showed themselves. We, on the other hand, with on long lines of transport, ammunition, hospital, hammocks, and other encmubrances, were confined to very limited movements, while manouvring, as that is mnderstood in Enropean warfare, was absolutely ont of the question. In the first place, we were, to a great extent, bound to the extremely narrow bush paths; and, in the second, we conld see nuthing save a few yards on either flank, and as a rnle not more than twenty in front when the path ran sufficiently straight to enable us to do so. The eneny, however, owing to the 
fact that they had bush-paths of their own rmning in every direction, which they knew to a nicety, conld more about rapidly and with perfeet ease throngh the dense forest on either side of ns. The bush behind some of their stockades was, indeed, a perfect network of paths and "runs," each leading into the other, and every one having some objectire, cither enabling one stockade to be gained from the next, or pointing a way of escape when hard pressed.

Bnt why, it may be asked, conld not our men follow the enemy along his own paths, as had been done in West Africa before and since? The reply is, that while this has been successfully managed in several of our operations here, it seemed to be impossible in this case orring to the impenetrable character of the bush not only bordering the main track, but which extended for a considerable distance on either side. Further, these paths were usually, from the cunning manner in which they were laid, quite undistinguishable by a European. Eren trained scouts could make rery little progress here. It was as if, like Milton's levils, we could " find no end in wandering mazes lost." On the few occasions when we did attempt to follow we usnally suffered sererely both in killed and wounded, and the enemy quite usnally got away scot free. The only way to subdne these people was either to kill or capture their principal leaders, or destroy their rillages and crops and keep on attacking until they were gradually driven to hiding in their more secluded haunts or sick enongh of the game to come in.

With regard to sending troops into the bush itself, I admit that this was done, and successfully, in the last Ashanti campaign. In the Timini country, and also in Mendi-land, the plan was tried, bnt, as I have already said, msnccessfully. Stockades were invariably taken by a flanking morement, an attack, that is to sar, on three sides at once. But eren then, owing to the impenetrable nature of the bnsh, it took some considerable time to cut round a stockade. 
The number of rounds of ammmition that were expended was prodigions for the result obtained. I can safely assert that it frequently took from fifty up to something approaching two hundred rounds for every man of the enemy accomnted for. Indeed, the only time that we did account for any appreciable number of them was at the commencement of hostilities, when they attacked in the open, or else in the hand-to-hand fighting in the stockades. Bai Bureh, besides having his men ambushed in every place where a British force was able, or eren likely, to go, was ahways extraordinarily well-informed both as to our numbers and movements. This, I think, he accomplished by sending a few of his own men to enlist with our column as carriers; and several ex-native soldiers and others who had been trained by our people returned to him on the completion of their term of service, and acted as his personal staff.

Here is an example of his watehfulness:-An ofticer having been engaged with the enemy eventually drove them off. $\mathrm{He}$ wished this to be lnown to a columm following some distance behind. With this object, he wrote on a piece of paper, "Safe from here to Karene," ran a sliewer through it, and stnck it in the gromd in the middle of the road. As soon as onr force went on the paper was at once seized by a lurking spy, who had taken in the whole proceeding, and carried to Bai Bureh.

Here is another example of their excellent scouting. I quote from a narrative of an officer of the West India Pegiment:-"Our column was abont to set ont for a town called Romeni, which had a few hours before been earefully recommoitred. This town is a nasty one to enter, as the approach is hedged in by a very narrow passage, through which not more than two men ean pass at a time. Coming within a few yards of the tomn, where all was silent and still, a single rifle went off from somerhere cluse ly in the bush, the ball from which hit a soldier in the head. We returned 
the fire by pouring several volleys in the direction we thought the shot lad come from, and then adranced again. Haring again carefully examined the position, the eneny were thought to have been either killed or driven off. Not so, however. Two more steps, and another gun goes off from the bush, and a second man is hit and this time killed. Again we fired all round the compass, again the position was reconnoitred, and again we advanced, only to have a carrier's skull splintered in pieces on the first step forward. This created much constemation, and rather maturally so, amongst the carriers, of whom many threw down their loads and ran in all directions. As we could not advance without carriers, the only thing to be done was to send back for more troops and guard our haggage where it was. No sooner was this being put into effect than we were attacked by hundreds of the enemy who had been all this time lying close romd us concealed in the forest, and it was only by the aid of the Royal Artillery and Maxinn grums which came to our assistance later that we ultimately forced this narrow passage and got into Romeni at all."

In the Safroka country were several missionaries who, since the outlreak of hostilities, had been detained by Bai Farima, a local chief and a staunch ally of Bai Bureh. Although these prisoners were, on the whole, fairly well treated, they were nevertheless in daily fear for their lives. The Rer. Mr. Humphrey had been murdered only a short time previously in a peculiarly brutal fashion, although, it has since been understood, against the wish and orders of Bai Bureh. He died like a hero, endeavouring to do grood up to the last:-

"His life was gentle and the elements So mixed up in him that Nature might stand up And say to all the world, "This was a man."

Later, Mr. Cole, a trader well known in the Kassi cumntry, 
who saw Bai Bureh some time afterwards, told me that the chief had expressed his regret that his men had killed $\mathrm{Mr}$. Humphrey, and had gone on to remark that he had caused the four men who had committed the murder to be put to death in exactly the same manner as they had killed their victim.

There were comparatively few massacres in the Timini rising, though, as is nearly always the case with West Africans, their enemies were put to death, and in a great many cases tortured. I was informed, and this on good authority, that Bai Bureh gare orders that all missionaries residing up-country, when the hostilities commenced, were to be allowed to go down to Sierra Leone ummolested. Whether this is correct or not I cannot say; but I do know that this chief, during the whole time he was fighting us, proved himself both a soldier and a man.

In the Mendi country it was very different. The inhabitants here are a much crueller race who constantly committed the most atrocious crimes, to some of which it will become my painful duty to refer later on in detail. Any attempt to rescue the missionaries detained in Kassi-land would have meant their instant massacre; and, besides, the road to Rogberi, where they were said to be imprisoned, was reported to be heavily stockaded.

The column now marched to Kaob, the quarters of a chief known to be more or less friendly to the whites. During a palarer with him he was instructed to destroy the stockades about his place. Although this was not actually done, a sixfoot road was, two days later, cut by him through the bush and three missionaries, Messis. Helmsley, Caldwell, and Father Castle, as well as several native missionaries and agents, were rescued and sent safely down to Freetown.

Henceforward our columms were pushed ont in all directions, and things seemed to go better with us. Colonel Marshall's tacties were beginning to tell. Owing to the density of the 
forests it had been found that a command of ten men was all that could be managed by one officer when actually engaged with the enemy; and when this was possible each column was split up into sections of ten each. The Winti road which had been blocked by the enemy was successfully opened by Captain Tyler, R.E., after several engagements, and on arriving on the banks of the Little Skarcies and Mabole Rivers, which were waded, the eneny were turned ont of a strong stockaded position on the further bank.

Colonel Marshall, in one of his despatches describing this portion of the campaign, says: "The fighting in these territories was, if anything, more severe than in the Kassi country. At Rosuit the column was received by a hot fire from several stockades in which the enemy maintained their ground for some considerable time in spite of flank attacks. They were, however, driven off with heavy loss and pursued into the country, their chief, Fodi Mauri, being killed outside the town."

Alimani Lahai, a general of Bai Bureh's army, was met by our column at Ronietta, and gave us a fierce fight. Eventually we found it necessary to shell and burn the town belind the enemy's position, which was done, but at the cost of several casualties, including Captain J. E. Harden dangerously wounded. The enemy in this action used " a large number of rifles," the fire of which, however, was, luckily for us, not very accurate, and, as is nearly always the case with these people, for the most part high. A large amount of powder was captured here, in addition to the war-drums of the ehief. After this our columns operated to the north-east of Kambia. On passing again through Alimani Lahai's territory more fighting, described officially as "strenuous opposition," took place; and on onr entering Sarcioy and Sumbogie "some very serious fighting occurred in which we had several casualties."

From Karene our force now marched to Magbantama, which 
it reached without opposition shortly before the convoy arrived from Romeni. Near the latter place the convoy had been fiercely attacked, and, thongh the enemy were finally driven off, our casualties included Lientenant Ricketts of the West India Regiment, shot dead.

Our object after this attack on our convoy (which, however, proved the last) was to clear the enemy out of the stockades and bush which sheltered them along the main pathway. After much tronble and several hours of marching and fighting this was accomplished, but as usual, owing to the immense bush, with very few casualties on their side.

One of Bai Bureh's stamnchest allies was a chief ealled Ba Forki, who had already made his presence felt by blocking the main road to Falaba, the headquarters of the Koina-Dugn district. Having prevented all foot passengers passing either up or down this road, the old chief went a step further and scized all the caravans coming down, collaring as much merchandise as he could lay hands on and imprisoning all the traders.

It was absolutely necessary that this freebooter should be punished, and consequently a flying column was sent against him for this purpose. The goal was Rofenka, the capital of his district. Here a sharp engagement took place, and several casualties oceurred on our side before the town was taken and burnt. On our return a stubborn resistance was met with at liamakka, and more casualties were added to our lengthening list.

Bai Bureh's power had by this time been considerably weakened. The British Lion was, he found, a tougher beast to tackle than he had bargained for, and although he had fonght well and bravely, and indeed splendidly, he was begimning to find that, in spite of our losses and sickness, he could not "exterminate us from his land," as he had vowed he would do. On the other hand, we were no nearer than we had been then to capturing the chief, although the 
Government had in the interval increased the reward for his

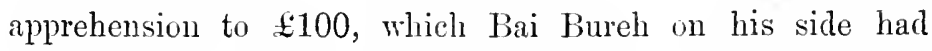
countered by an offer of $\$ 500$ to any one who would bring him the head or person of His Excellcney the Gorernor. The Bai was certainly magnificently guarded and hidden by his war-boys, and, what is more, was often present in person to direct the operations in the more important engagements. His boast was that "he would live to-day in the place which he had destroyed yesterday." He was always, therefore, pretty close to our columns, but in exactly the opposite direction to that in which we were hunting for him.

We paid at this time a few days' risit to Bai Forki's country, in order to punish lim for his blockade of the Falaba Road. Our force encountered strong opposition, as usual, during this march, and several casualties occurred. The enemy invariably set fire to their own towns when they had to retreat, with the idea, I suppose, of checking our advance and thereby giving them time to escape and hide or ambuscade themselves in the forest. After this the Falaba Road was left open, and, thongh this chief's warriors no doubt attacked us subsequently, they did not attempt a blockade again at this part.

A report had come in that the people in the Massimeia country in the Kevalu district had risen, therefore a specially picked flying column was despatched to Mabile, the capital. Strong opposition was met with during the whole of this march, but the enemy were dispersed and several other towns were burnt. An effort was now made by the officer commanding the operations to call in some of the important chiefs of Massimeia with the idea of arranging terms of peace. This was accomplished after some delay, and two American missionaries, Dr. and Mrs. Ball, were also resened from a place called Kunso. What their state of mind must have been during the time they were shut up in that place, I do not know. It must have been a truly terrible one, full of anxiety 
and suffering, and with the dread of losing their lives in the most horrible way hourly before them.

By this time the power of several of the more important chiefs had been broken, while many had been killed or taken prisoners. The latter had been sent down to Freetown. The enemy, who had given so much trouble at Rokell, and destroyed the trade there, had been scattered and the river reopened to traffic. Bai Bureh was now, thongh still at large, a hunted fugitive. Most of his towns had been burned, his crops destroyed, and his power broken, and he limself was living a hand-to-month existence in the bush. Besides, the whole country was now in a terribly flooded state from the leavy rains which were in full swing.

A large garrison was left at Karene, which had been provisioned for six months, and the remainder of the troops returned to Freetom on the 10th of Jnly.

Any one who has had the misfortme to find himself in a West African forest in the rainy season will sympathise with our men, subject, as they were, not only to continual exposure, night and day, to tropical dompour's, but compelled to fight as well as march in the rain, and as often as not to go hungry to rest at the day's end. By the time the jaded columns left the seat of war both officers and men were fairly wom out and very badly in need of a rest. Thronghont the long series of fights the troops had belared excellently. There was never any shirking from duty, no matter how arduous, whilst often, for days together, the men were wet to the skin and continually opposed to an invisible enemy. The climate also was finding out nany officers and men. Lientenant Corbett was taken ill with fever one day, but continned marching with the colmmn. He struggled on until the evening with a temperature of over $103^{\circ}$. He was, however, at length compelled to give in through sheer exhmustion, but had only been in hospital a few hours when lee was carried off", another victim to the fever fiend. 
I cannot do better than give in this place another extract from Colonel Marshall's despatch on the behaviour of the troops during the fighting in the Kassi country. The despatch says: "The behaviour of the troops throughout the operations was admirable. Before the commencement of the movements of the flying column the tornado season was already well advanced; the men were constantly soaked to the skin in the marches, and, as they hat no change of clothes, were obliged to remain in their wet garments; nearly every night the bivouacs were dehged with rain; it was comparatively seldom that the troops were sufficiently fortumate to sleep in towns, for if the last town attacked during the day was not set on fire by the shell fire of the attacking party, it was frequently burnt by the enemy on being driven out, so as to leave no shelter for our troops. These discomforts were not only borne uncomplainingly by the men, but even cheerfully." The despatch continues: "The conduct of the troops under fire was excellent. Although they knew the enemy was sheltered behind stockades which were proof against shellfire, and very nearly so against rifle fire (for occasionally a bullet would find its way throngh the interstices or througl the bamboo loopholes of the boulders) they nevertheless fearlessly faced the enemy's fire, sectional volleys being delivered with a steadiness that would have been creditable on parade."

During the earlier part of these operations scores of incidents occurred which I should like to narrate, but which would make my narrative too lengthy-acts of valour on the part of both officers and men, as well as instances of devotion to duty under dreadfully trying circumstances. The officer commanding, in his despatch, speaks of the small number of our casualties. This, I think, is open to question. When the number of our troops, the nature of the country, and the small amount of damage that we inflicted on the enemy are all considered, I should say that onr casualties were tolerably 
heavy. In the Kassi country alone, during the attempt to apprehend Bai Bureh, our wounded, sick, and missing at one time totalled and even topped six hundred. On this subject the despatch from which I have already quoted goes on to say: "The small number of casualties, when eompared with the intonsity of the enemy's fire, is accounted for by the celerity with which the flying colmmn eame into action, and so diseoneerted the prearranged plans of the enemy. The men of this columm were sometimes changed, but the same officers remained, and as section after section came up a word or two from an officer was sufficient to ensure the right impulse and direction being given to it."

The obstacles which gave our men the most trouble throughout the operations were the stockades. Let me give a short description of the way these formidable structures are built and defended. And, imprimis, I may remark that in searching. for these stockades, it is well to look for them in the thickest and most impenetrable part of the forest. Even then it is almost impossible for Europeans to loeate one of them. Even the West India troops conld not often do it, although occasionally some clever native, whose powers of observation must have been especially acnte, was successful in spotting one of them. Wherever they were fixed, there was absolntely nothing, to our eyes, to betray the secret; no earth downtrodden in the road, no bushes trampled under foot, no loose twigs or broken pieces of wood scattered conspicnonsly about. Still, a stockade was sometimes loeated by a West Africin bush-born native, whose method of working wis to cantionsly creep or wriggle along, with bent back, and carefully exanine any place which, for reasons of his own, he would consider likely to hide one. If he discovered an atom of a pice of bark ehipped off a tree, or a tiny twig, perhaps ten feet from the ground, snapped or broken, or the finintest of faint immprints of a naked foot on the side of the path-signs which you or I would probably never discorer, did we search for a month-he 
would predict that a stockade was lying hidden within a few yards, and he was generally right. Numbers of these stockades, scattered about in every direction in the bush, were only discorered by the enemy opening fire at point blank range with the ineritable result of several men being hit, the carriers demoralised, and the enerny encouraged. For our return fire, which was at first directed at the stockade itself, laad no effect whatever, and it was fonnd after experience that the only method of demolishing these strongly-built shelters was to cut round them from each flank, while the enemy were being engaged in the front. When it is considered that thirtyseven stockades have been encountered during one not over long march, each proof against the most modern rifle or a T-pounder shell, it becomes easy to imagine the difficulty our men often had when proceeding with hosts of carriers, hospital hammocks, and the other encumbrances which accompany a British eolumn on the march from one place to another.

The stockade itself is built of boulders, stones, great logss of wood and sometimes the soft spongy bark of the banana-tree, with a trench fom feet deep behind it. Given the above, with a thick forest and a commanding situation, and you have all the material for manufacturing one of the most formidable obstacles that has been built in West Africa, or elsewhere, by savages to hinder the passage of troops. The logs of wood used in the making of a stockade are about nine feet long, and are driven about three feet ints the ground with the remaining six above. The diameter of these logs will be, roughly, from fourteen to sixteen inches. When they are in position, and have been firmly bound together, huge boulders are placed against them, forming a solid stone wall some three or four feet thick. A skilfully-dug trench is eut behind the stockade to afford protection to the firing party, whose aim is taken through hollowed-out picees of banana stalk or bamboo placed in a row close to the ground. Usually stockades were situated from six to twenty yards from the path and located in the very thickest part of the forest. 
Colonel Marshall gives a very good description of these stoekades in his despatch. He says: "It is absolutely impossible for Enropean eyes to diseern them by any ontward sign; occasionally an exceptionally quick-sighted native will discover the locality of a stockade by some indication, sueh as a dead twig or some drooping leaves overhead. The places mostly ehosen are the erossings of fords and rivers, thick gullies, a sharp turn in the road, the top or bottom of a hill, so long as it commands the path, and the densest bush in the vicinity of their towns. They are often built in groups, giving mutual support. The shells of the 7-pounder break to picees on coming in contact with these boulders. A sheltered line of retreat down some small slope leading to a pathway eut in rear enables the defenders to retreat in comparative safety. Owing to the density of the bush it is impossible to rush them."

The return of a large number of the troops to Freetown in July did not mean that the operations against Bai Bureh were ended, but, as I said before, the chief"s power was very much shaken. Many of his followers were seattered, their towns destroyed, and their women and ehildren foreed to flee to other lands, some into Freneh territory and others into Mendiland; while yet others found their way to the Namoh River and crossed into Liberia. It may be asked, how was it that an unedueated native, sueh as this chicf appeared to be, was able to keep his force so well supplied with arms and ammunition, to find provisions in a country devastated by the British columns, and to be in possession of the money which he was known to have pair to many of his allies for their assistance? Well, with regard to the guns and rifles with which his men were armed, these were either ubtained from the traders in the Colony and Protectorate, stolen, or taken from such of our men as were killed during the operations ; a part of the rifle ammunition was likewise stolen or eaptured during the fighting. But it great proportion of the breechloalding 
weapons, as well as powder, were undonbtedly purchased in French territory. Bai Bureh must have been quite well off also as regards gold. Apart from the fact that several Government messengers from Falaba were seized and plundered by his war-boys, he had himself accpired considerable private means in one shape and another, and a sum of at least a hundred pounds was taken from poor Humphrey when he was murdered at Rogbati. The Timinis may have been hard up for food. Most likely they were; nerertheless, there is no doubt that at first they had large reserves of rice and cassava stored away in the depths of the bush. They were fortunate, likerise, in obtaining a large quantity of our own stores, chicfly owing to the carriers throwing down their loads and bolting when under fire.

Anylow, wherever these prorisions, rifles, and ammunition did come from, the fact remains that the chief seemed always to have a goodly supply on hand, sufficient, at any rate, to see him through a large portion of the fighting. 


\section{CHAPTER IX}

THE DEFENCE OF KAMBIA

"Tis not the least disparagement To be defeated by th' event; Nor to be beaten by main force; That does not malie a man the worse. But to turn tail and run awuey And without blows give up the day, Or to surrender to th' assaultThat's no man's fortune, but his fault."

TT is a big jump from the Rokelle to the Kittam River. The Rokelle-in the neighbourhood of which we have just been fighting--is, indeed, no more like the Kittam than the Nile is like the Ganges. But it is neeessary to make this leap in order to get once more into Mendiland; for in that country and from Bandajuma it was that I now began to make preparations, after a brief rest, to set out again on tour for the purpose of "whipping up" certain chiefs and their people in the matter of the House Tax.

My route lay in the vieinity of the Boom Distriet, and I started off from Head yuarters with only a few personal stores, a hammock, camp bed, some blankets and mosquito eurtain, and the necessary cooking utensils. Accompanying me were an interpreter, one corporal, two lance-corporals, twenty-three privates, and my own soldier orderly. Each non-commissioned officer and man had fifty rounds of 303 anmmunition. 
I had 94 rounds of $\cdot 303$ ammunition for my own carbine, and 150 rounds of revolver ammunition, which was strapped round the waist of my boy, Fodi, who tramped behind me.

It would be wearisome were I to go into a detailed account of this journey, or yet attempt a description of all the chiefs I visited and the towns I passed through. It will, however, be necessary to give, in outline, the results of my visits to some of the larger towns along the route.

Before daylight a number of carricrs were collected outside the bungralow. A packed bath and other travelling necessaries were lying outside ready for the journey. At six o'clock, the men who were to form the escort fell in with the carriers in line, and ten minutes after that, just as grey daylight was erecping across the sky, we swung out in line down the slope of the hillocks across the Wanje river orer to the bush towards Jouma. At Pujuhnn we halted after an eighteen-miles march, and I harl an interview with the chief, Mono-jah. This chief had recently been arrested for nonpayment of the Tax, but, having paid something "on account," had been released by the Acting Commissioner. Momo-jah was an interesting person to talk to. He knew the country and the people as well as any man, and was considered a great warrior and authority on warlike matters by the other tribes. He had certainly witnessed much bloodshed and had taken a prominent part both in the local wars against the Timinis and in slave-raiding expeditions into their country. Many and hideous were the stories told of the harsh treatment that he meted out to his luckless prisoners. One story he himself told me-of how he went to make war upon another chief in the Bandi country in order to punish him for stealing slaves; how 5,000 of his war-boys tracked the tribe down to their own country; and how they lay like snakes for many hours mider the banks of the river which ran close by that town, waiting until the unsuspecting tribesmen showed themselves. His eyes glistened as he went on to 
describe how the enemy fell into the ambush, and how his warriors rose upon them, and hacked, and hewed, mntil at the end of two hours' slaughter there was not one left. To use his own words, "The rery slaves themselves were chopped!" Nomo-jah had certainly seen life-sarage African life, that is-and was full of stories that would have filled a boy's book of adventures over and over again.

On being asked the cause of the war and why his people massacred British subjects, Momo-jah, who could never forgive us for our opposition to the slave trade, replied, "You know when I want to fill my belly I get a big bowl and fill it with rice. But that is not enough. Before I eat I put i little pepper, or soup, or green-stuff on the rice. That does not fill my belly ; it is the rice that fills it."

After learing the Kittam and Krim countries I crossed to the Jong Distriet, making my headquarters at Kambia on the Small Boom River.

As I have already stated, my object in coming on this tour was to facilitate the collection of the House Tax. This was, in fact, one of the most dangerous parts of the country, the majority of the inhabitants being half Mendi, and half Sherbro, a combination of all the vices with none of the virtues of either tribe.

I had already been in the place for some eight days, and used to start off daily to visit such of the local chiefs as lived within a day's march of my temporary residence. Upon these occasions I was never accompanied by more than three persons-nsually by my boy, Fodi, and two soldiers. Sometimes I used to start ont with Fodi alone.

Fodi was a nost amusing as well as a faithful servant; a pure-bred Timini, whose English it took me some little time to miderstand. Indeed, to the last, whenever he got exeited, he became perfectly mintelligible. Here is a characteristic example of his style of conversation:-

"Massa! dat Mendi cook nar come ont Si-Lon nur tief 
man bad. Massa, ye own under-rest I find um all abont, but 'e no lib. I de take um, I de hang um close nar kitchen. ask de cook which side 'e de and de cook say'e no see 'em at all. Massa, I look so tay I tire. Dat man de! ah! 'e fit for hell for true. I no sabbe which side 'e come out. I no de like um at all."

(Anglicé-"These Mendi people are bad. The big black cook who came from Sierra Leone is a big thief. Master, I looked for your under-rest everywhere, but it was not there. I asked the cook where it was, and he said he had not seen it. Master, I looked for a long time until I was tired. That man ought to go to Dante's Inferno. I don't know where he came from. I don't like him a bit.")

I had been haring some trouble with a Jong chief named Katah, who lived in a town called Old Lnawah. This man was of immense stature, was a pure-bred Mendi, and was literally corered with scars gained in fomer battles.

He thought of nothing else but making war, catching slaves, and plundering. Another Jong chief named Koung, a relative of Katah's, who lived at a town called New Luawah, was just such another man. During my stay at Kambia several of the local chiefs had been in to see me, many of them bringing something on account of the Tax. Among these was Chief Berri of Bongeh, whom on account of suspicious conduct I detained. I had sent sereral messages to Katah, either to come and see me, or send his Larari (speaker) with something on account of the Tax; but this he refused to do. Rumours now began to reach me that a tribe called the Boompé, one of the most warlike in the country, had refused point-blink to pay the Tax, and were going to fight, and that Chief Katah had started for the Boompé country in order to juin them. These rumours were discredited and langhed at by all the Sierra Leone traders in the place, who had resided among the people for years, and I, who knew very little about the cuuntry or the people at that time, was persnaded intu beliering them. 



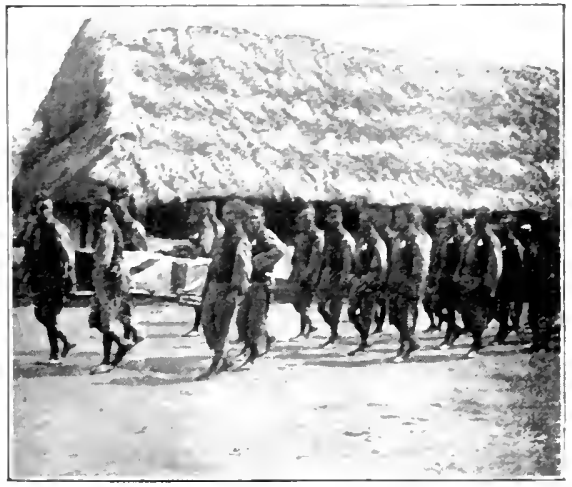

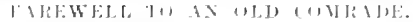

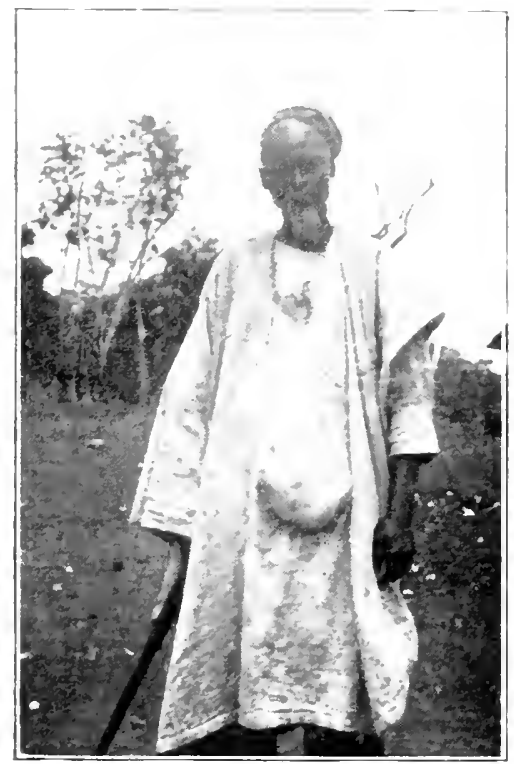

CHIEF TOO' V.

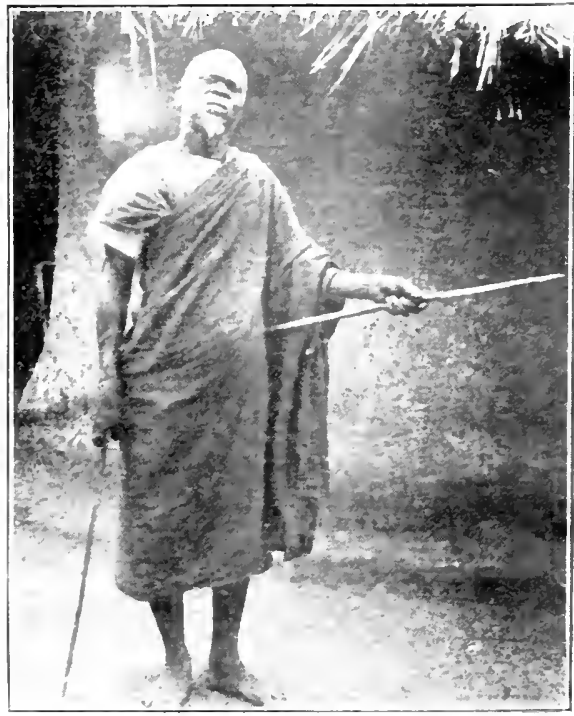

CIIJF h.IAI UI JLAWHH. 
On the evening of the 23rd of April, a report reached me that Chief Katah had actually started for the Boompé country, whither he had gone to get help to make war against the Government. Upon this report, I despatched, the following day at 6 a.m., a lance-corporal, named Macaulay, and three men to effect the arrest of Katah and bring him before me. Two days previously, a sergeant and three men had arrived at Kambia, having been on escort duty conveying specie to Sherbro. I detained them, and they remained with me at Kambia throughout the subsequent fighting.

On the night of the 21 th, another report reached me that the corporal and the men had been detained by the natives at a place called Senahn, and that one of the latter had been killed. On the following night the detachment returned, and reported to me that at Senahu the natives had refused to sell them food, that a crowd had come round them in a threatening manner, and that, in order to get through, they had fired their rifles into the air to scare the people. Also, one of the men was missing; had got behind and could not be found when they were leaving the town. Another man had rushed at the corporal and endeavoured to seize him. The latter, in self-defence, was forced to strike the fellow with his rifle, and felled him to the ground. I wish this to be quite clearly understood. I went very carefully into the matter later and the facts are exactly as I have stated them. In the evidence given before the Royal Commission in 1898 upon the rising and its immediate causes, some doubt was expressed as to whether or not the corporal and his men were to blame for this aftiray. I maintain that they were most ilecidedly not to blame.

On the 26th of April I set out, accompanied by a lincecorporal and armed only with a revolver, to visit the large town of Bramah, a distance of some nine miles from Kambia. On arriving I found the place, which was usually full of people, practically deserted. I saw only four men in it, who 
were sullenly walking about. They took no notice whatever of me. I returned to Kambia the same evening. The bush on either side of the path was immensely thick the whole distance, and both at Bramah, and during my return journey, I had an instinctive fecling that something was wrong. It undoubterlly was, though I had no jdea at the time that the dense bush on either side of me, both coming and going, that day, was full of hundreds of lurking blacks, who were only waiting for a favourable opportmity to capture, torture, and finally cut the throats of the whole lot of us.

All ready were they, but the time was still not quite ripe for slaughter. The last stone had not yet been throun axiay.

On the day following, that is the 27 th, I was taking chota hazri-early morning tea-at 6 a.m., when I heard a deafening row of horns blowing and drums beating, mingled with shouts and dreadful shricks. At first I took little notice, imagining that a native dance was proceeding, or that some chief or other "big man," as they say in this country, had arrived.

Five minutes later my hoy Fodi came rushing into the room in a frantic state of excitement, cxclaiming--

"Massa! Massa! De war done come! De war done come! De Boompé done come!"

On hurrying to the door I saw MIr. James, a Sicrra Leone merchant, and a nian of education and considerable attainments, who was living in Kambia at this time, staggering across the yard, cut and mutilated in a shocking manner, and literally dripping with blood. In his arms he held his little son, a child of about five years old. The boy had a fearful gash, at least six inches long, across his head, and was quite dead.

I was so utterly taken aback by this dreadful sight that for the moment I turned deadly sick. Then, realising that something awful must be taking place ontside, I picked up my 
revolver and rushed ont into the road. There, I met my men, just roused from sleep, flying helter-skelter into the enclosure from the town; some half-dressed, with neither coats nor hats on, but all carrying their rifles, with belts, pouches, and ammunition.

Mcanwhile the noise, what with the shrieking and shouting, the blowing of horns, firing of guns, and beating of drums, was simply deafening. I conld see large bodies of naked men dancing and howling, and waving guns and swords over their heads. The sergeant now rished up and told me that the Boompé people had come down in great numbers, that the Jong people had joined them, and that they intended to kill us all. Already several Sierra Leoneans, men, women, and children, who had not been able to get inside our enclosure, had been butchered, or were then being murdered in the town, not fifty yards away from us.

The men had fallen in, and I posted them as quickly as possible in positions commanding the road approaches to the yard, and from which they could best defend the place. All this had not occupied more than a few minutes, though it takes longer to tell, when my men opened fire on a party of the enemy who were endeavouring to pull down the fence at the furthest comer of our enclosure, some fifteen yards distant. At first the shooting on both sicles was shockingly bad, the bullets all going high. I now got my first shot at a human being, a lig, naked fellow armed with a huge sword; but, owing no donbt to over-excitement, I missed him, much to my disgust, and he was brought down by a man standing next to me. 'The next instant this Frontier also was dropped by a shot full in the face, cansing a terrible wound, while the bullet in passing smashed the second button of my jumper and ent throngh my leather whistle-strap.

We were now lootly attacked on three sides at once, the enemy's undearours being directed, with some snecess, to pulling down the wooden fence which surrounded the honse 
and yard. They lost heavily, however, whenever they showed themselves in the open, and after an engagement lasting three quarters of an hour were driven back, taking their dead and wounded with them. But they remained in the bush firing at us for quite an hour longer, until a bayonet charge finally cleared them out.

It was necessary now that something should be done for the women and children who had managed to escape from the hands of the infuriated tribesmen to gain protection in our enclosure. Certainly their presence placed an additional and heavy responsibility upon my shoulders. Anxiously I returned to the house, only to find $\mathrm{Mr}$. James lying in a great pool of his own blood, while the dead body of his little son lay on the sofa beside him. Nearly every one seemed paralysed into doing nothing, but with the help of my boy Fodi, I tied up his hurts as best I could and succecded in staunching the flow of blood. After that I put the women and children into some canoes which luckily happened to be on the premises, and sent them down to Sherbro in charge of one of my men. I subseruently learint that they reached that place in safety.

Meanwhile I sat down and wrote a despatch to the Governor, informing him of the state of affairs, and asking for immediate reinforcements. This I direeted to the Commissioner at Sherbro, to be forwarded to Sierra Leone with a covering letter explaining the gravity of our situation, and asking for any assistance he could spare, but especially for ammunition. I sent these letters down by canoe in charge of a Court Messenger, and with him went Mr. James and the wounded Frontier. Mr. James's little son was buried by the river-bank before his father left. 


\title{
CHAPTER $\mathrm{X}$
}

\author{
THE DEFENCE OF KAMBiA (continued)
}

ForEsEEING the extreme likelihood of another attempt on the part of the enemy to capture us, I set to work at once to strengthen our position. This I was able to accomplish by means of a number of empty rice bags, casks, and barrels which we found in the store and which, when filled with earth and stones, made a fairly effective breastwork. We also built a rough sort of stockade and, in fact, filled up every gap possible. The men worked well and cheerfully, langhing and joling as they discussed together the events of the morning.

My total strength at first was one sergeant, one lancecorporal, and twenty-five privates, every one of whom had fifty rounds of ammunition. There were in addition my boy Fodi, the erring cook, and four hammock-boys, all of whom were Timinis. My six carriers had absconded at the beginning of the fight, and had in all probability joined the enemy. In the yard there were also five natives, belonging to the owner, who could speak English and who joined ns. My personal battery consisted of a service revolver with 150 rounds of ammunition, and $I$ had in addition the rifle belonging to the wounded Frontier with all the ammmition that was left him, and my own carbine with ninety rounds of 303 ball. In the honse were also found a Martini-Henri rifle and from 200 to 300 rounds of ammunition. The sheds and ware-rooms of 
the factory were stored with bangar, ${ }^{*}$ but unfortunately there was $n$ rice to be found in the whole place and in the shop itself was nothing edible. My men had barely enough food for one day and my stores were ruming short, as I had intended sending in to Sherbro and replenishing them a few days befure the ontbreak. The quantity of produce stored here was considerable, however, as the owner had been authorised by the Government to receive tax-payment from the local chiefs in kind or cash. I was informed afterwards by him that there was a good sum of tax-money also in the place when he escaped. But this, although I searched everywhere, I was mable to discover.

Meanwhile, a Mr. Pobinson, a Sierra Leone trader residing at a place called Suntook, on the Small Boom River, and within half a mile of Kambia factory, on hearing the somd of guns, managed to make his way to us through the bush, and was able to give me valuable information as to the movements of the enemy. To this gentleman I gave the Martini ritle and a hundred rounds, and he rendered me great assistance in the events that followed. Mr. Robinson was an old hand, and had been attached to more than one expedition previously; he was also a fair shot.

Nothing further occurred that day, although we were of course fully prepared, and on the alert; lont at $3.30 \mathrm{a.m}$. the following morning, in the inky darkness, another attack of a more serions nature took place. Our attention was first called by one of the sentries who declared he had heard a faint noise in the bush in front of him. The hearing of these men is exceedingly sharp, and I and the Sergeant standing by the sentry endeavoured for some time, in vain, to ascertain the canse. But we could make ont nothing. Now the Mendis are at their best when making war, or ratler, going to nurder, in the night. The usual time for their attack is between 1 and 4 a.m., when they say that man sleeps soundest.

* The local name for palm kernels. 
Owing to these tactics they have been most successful in attacks on other tribes, and they are head and shoulders above any other race I know of in the wonderfully silent way in which they are able to move through the thickest forest in the pitch dark. They are, in fact, like cats in their stealth and cunning, and at such times it behoves one to be as wide awake as possible in order to avoid a knife being jabbed into one's body from some lurking foe. Their object in attacking at night is to ereep up and get inside the town, and, if possible, into the very honses. Then, at a given signal, when all is ready, each man having previously selected his victim, they give one awful yell and commence their work of butchery.

The sentry who had first heard the noise, and who had remained fixed and rigid, never removing his eyes from the spot whence he said it came, now asked permission to fire, which was granted. There was a spurt of flame from his rifle-muzzle, accompanied by a report which somded donbly loud in the stillness of the night.

The slot was immediately returned from a distance of, at most, ten yards, and the next instant there arose a weird and blood-curdling yell from the bush all round us. That sentry's ears had not deceived him. He had noted the faint rustle of some leaf or the crackle of a twig as the Mendis came on stealthily as leopards-creeping, creeping, slowly into our midst. We were, as before, attacked on three sides sinultaneously, and in their first onslanglit the enemy sncceeded in further smashing in the fonce and in getting into our cnclosure, where they made a determined effort to set fire to the roof of one of the outhouses. Every one who took part in this enterprise was shot down, and, althongh we could scarcely see at what to aim, the enemy were forced to recoil before the withering fire poured in. That great numbers of them were present there is not the slightest doubt; and if they had for one moment pulled themselves together and "rushed" us, the end wonld have been very speedy. This, 
however, they were too great curs to do, and the more they reviled and cursed us, and shonted that they were coming to cut our throats and burn us alive, the more my men jeered at them, and challenged them to come and do it.

At 4.45 they had had enough and cleared off, but kept up a desultory fire-which, however, did us no harm-for quite an hour longer. What their losses were I camot say, probably exceedingly small, as in the darkness and excitement there must have been very few hit; and, with the exception of those who succeeded in getting into our enclosure, we saw no dead bodies at all. Our casualties were, two men slightly wounded, and two labourers wounded, one severely.

We were not troubled further by the enemy that day, althongh we knew they were all abont us in the bush, watching our every movement.

It had by this time become abundantly clear that Chief Berri, whom I had detained as a prisoner, was playing us false. During the late attack he had been continually calling ont in a lond roice, in Mendi, that we did not know what to do and that our ammunition would soon be finished. This was, of course, for the benefit of the enemy, and they undoubtedly heard and profited by it. While he was thus occupied, he was pounced upon by three stalwart Frontiers, who in a moment had him gagged and secured and bronght before me, when I ordered him to be locked up in one of the rooms in the factory, and thus put an end to the old gentleman's pleasant little game.

I now began to feel serionsly alarmed about our scarcity of ammunition. A good deal had already been expended by the men, who were exceedingly excitable and often fired at objects they had not the slightest chance of hitting. I had already impressed upon them all the importanee of husbanding every round, and told them that unless they did so, we should inevitably fall into the hands of the enemy, and they all knew what that meant. Nevertheless a great deal had, as I have 
said, been recklessly expended, and that morning I took several rounds from each man to keep as a reserve. Some of the men now had actnally only three or four cartridges left them. I was also not a little mneasy at receiving no message from the Commissioner at Sherbro, and every hour we were looking for a boat bringing help and ammunition; but none came.

At 11 a.m. that morning I called for two volmuteers who, disguised and stripped, were to endeavour to get letters through to Bandajuma, the headquarters, a three days' march direct, or, as they would go, a journey of some five days. Two men volmteered, and by their hands I sent an urgent despatch to the officer in charge of the force there asking for immediate assistance.

He never received my letter. The men were captured by the Mendi, who mudered them with their usual savage cruelty.

We were now getting very short of food. The men had eaten all their rice, and I had to draw on my fast vanishing stock of stores to feed them. There was not a fowl or a sheep in the place, everything had been taken away and plundered.

Nevertheless I resolved to remain, and my object in doing so was fourfold: First, the property was a valuable one, and the place contained tax payments of considcrable value; secondly, in the event of Bandajuma needing assistance, if attacked later, Kambia would, from its situation, make an excellent advanced base, or " half-way house," for troops on their way to the interior; whilst the place was in direct communication with Sherbro, and consequently with Freetown by water. Thirdly, I had asked for reinforcements from Freetown, Sherbro, and Bandajuma, and was hourly expecting the arrival of help from one or other of these places. And, lastly, I was at the moment maware that this was but the commencement of a general rising throughout the comintry, and 
believed it to be the affair of a local tribe merely. I considered that to yield now, and leave this property in the enemy's hands, would have had the worst possible moral effect, discounting, as it wonld have done, the prestige of our arms in a country but newly ranged under the British flag.

At $11.30 \mathrm{a.m}$. on this day-the third since the commencement of the ontbreak - we were again attacked by a mnch larger force of the enemy, who displayed their usual tactics. During this attack the noise was simply awful. Several deeds of bravery were performed by individuals of my force on this occasion. Lance-Corporal Macaulay, a man who, since the commencement of the attacks, had distinguished himself frequently hy his dash and courage, engaged three Mendis at once at close quarters when entering a narrow passage which they were endeavouring to force. He shot one of them, bayoneted the second, while the third man ran away and thus probably saved his bacon.

Another Frontier, Private Kanu, lad shot two of the enemy at close quarters, and being mable to reload in time and not having his bayonet fixed, seized a sword which had been dropped by one of them and with it killed a third man who was at the moment rushing at him with a spear. I have that sword and spear in my possession now. In fact, all the men behaved splendidly, and Sergeant Williams especially, by his coolness and judgment, proved invaluable to me at this time.

The enemy now tried new tactics and attempted to burn us out. Already the new town was in flames, but it was, of course, too far off to affect us. We could sec the enemymost of them stark naked, many of them drunk-darting about, with firebrands in their hands, among the burning houses. A bayonet charge, however, into their midst effectually cleared them out of the town for the time being.

Meanwhile the other town-called by way of distinction 
the "old town"- -had been set on fire, although I had done all that was possible to prevent it. This was serious, as it was built quite close up to the factory outhouses, and there was immediate danger of their catching fire. It all depended upon the direction of the wind. There was very little then; sometimes a puff would blow the roaring flames one way and sometimes another, but never near enough to do us any damage. However, it was very necessary to unthateh them, so I sent two of our labourers on to the roof of the sheds for this purpose, while my boy Fodi climbed on another and began rapidly tearing off the dry covering of split bamboo. This, of course, drew the enemy's fire at once. I had barely turned round to shout to the two other men to make haste with their work and come down, when I saw Fodi slide limply from his perch on the roof of the third store and tumble flat upon his face in the courtyard below-dead, with a Mendi bullet through his heart.

The death of my faithful servant in the discharge of his duty was a bitter blow to me. I felt furjons against the enemy and resolved that, come what might, we would pay them back with heavy interest. And if it came to a last stand with our bayonets, at least our names should be remembered by the savage foes who took our lives.

I was now fecling really unwell, with a high temperature, and had had little to eat sinee early the previous morning. My cook, who was boiling the last of the rice for the men, had just been driven from the kitehen (which was a little round hut in the yard) by the shots of the enemy, and came to me and said dolefully :-

" Massa, dem ball done seatter all de fire!"

It had now become necessary to use extreme cantion in crossing the factory, as some five or six of the enemy hidden in the bush near by had been steadily sniping us for some time past.

After another futile attempt on this day to capture our 
position they again retired, shouting to us as they did so that they had gone to get more men and that hy to-morrow we should all be buming alive. Some of them did return at about 2 p.m., but ouly skimished in a very half-hearted manner, making no direct attack, but continuing to fire at us from the bush. This sniping resulted in one of the labourers being severely wounded in the lear.

There was no sleep, of course, for any of us during this long night, the third since we had been besieged. We were by now suffering much inconvenience from the stench of the bodies which lay about the place and in the paths, and which the enemy had not been able to drag away with them. The whole scene is still as clear as possible in my memory. The night was pitch dark, and there was a heariness in the air which presaged the corning of a storm. Occasionally a puff of wind would sough eerily through the trees, and on the breeze would come the dismal hoot of a far off owl, or the crackling cry of a nightjar-often no doubt a wingless bird. Otherwise there was nothing to break the death-like silence of our forest-wrapped enclosure, on which "the pale beauty of a thousand stars looked down from hearen's high battlements."

My men were as alcrt as, aftcr three successive sleepless nights, was to be expected, and I could now and then make out a faint rigid outline as one of them endearoured, with straining eyes and earbine ready in hand, to penetrate the black curtain of the night. My own nerres were in a terribly "jumpy" state; and whilst creeping about from post to post during that long and never-to-be-frorgotten time of suspense, I would fancy that I heard all sorts of weird, unearthly sounds; the rustle of a leaf, or the creak of a branch would make me start and send my hand to my revolver, in the instant expectation of seeing some lurking savage spring up before me from the darkness.

At length the long, weary night began to wane. The sky 
paled slowly, and with the light there came a dank and writhing mist which hung over the trees and the black water like a smoky cloud, showing each leaf and bending grassblade tipped with a tiny point of dew, that gleamed and glittered fitfully, like diamonds shining dimly through a marriage veil. The day paced slowly forward, and very cold and cheerless under its pale influence looked the world of tangled undergrowth around us, until the sun had struggled up above the eastern horizon to recommence his daily trip across the sliy. A little bird, more early astir than any of his kind, would now and then chirp ont as if to rouse his lagging fellows from their rest; and as the infant light was born, a cock, as British, by his voice at least, as one could wish to hear, gave out his old familiar crow that, sounding faintly in the distance far away, waked in one's mind old memories, long sleeping, of the fair green fields of England, and of pleasant days gone by. After our all-night vigil my men and $I$, wet throngh and through as we were, must have presented a particularly draggled and disreputable spectacle, as we looked into each other's faces in that dim daydawn.

At $6.30 \mathrm{a} . \mathrm{m}$. the enemy again opened fire upon us and attempted to rush the weakest side of our enclosure, but unsuccessfully, and after about an hour's fighting, part of which consisted in their sniping at us from the bush, they were finally driven off.

We had received no news of the boat with the help that I was expecting from Sherbro and Bandajuma. As a matter of fact, the Commissioner had written to me saying that he had not a rifle or a round to spare. The whole country was, he wrote, up in arms, and Sherbro itself was threatened with attack ; if that occurred, a massacre would probably ensue, as there were practically no arms to defend the place with. But the messengers were mable to get through with his letter, and had to return to Bonthe, so I never received it. 
Now, on the opposite side of the river, which was open grass land for almost 400 yards back, I could espy black figures continuonsly passing and repassing, some with sticks and faggots on their heads, others with what appeared at that distance to be spears, swords, and guns. And here I may remark that the native, at the beginning of the rising, displayed a supreme contempt for the Martini carbine with which the Frontier men were armed. This was a ·303 Army Martini-Metford carbine, a most excellent and reliable little weapon for use in the African bush. But they used to say that a gun with so short a barrel, and one which fired so small a bullet, could not do much harm to them or to any one else, their own weapons being old muzzle-loaders with a huge gas-pipe barrel, about six feet long, which they used to half fill with slugs and often, owing to the recoil, fire from the hip.

On seeing these people continually passing to and fro, I sent a chance shot in amongst them, much to their surprise and consternation. They immediately ran in all directions and were not seen again.

The sitnation for all of us had by now become most desperate. This was the fourth day and no assistance was forthcoming, whilst ammunition was also getting very scarce. Some of the men, in fact, had no rounds left, while others possessed, some eight, some ten, or, at the most, perhaps twenty cartridges. There was no doubt that the enemy had obtained large reinforcements. Each time they were driven off they sent for assistance, and as a matter of fact we had all the Jong comntry, a great number of the Boompe people, and a large portion of the Kittam country in addition, ranged against us. Each chief would send his own "war" or detachment of fighting-men, and their instructions were to take us dead or alive-better alive, they thought, for the fun that they would have in torturing us.

The enemy's game was now to build stockades aroumd the 
place, and, lying securely behind these, to smipe us continually, and to attack us at night whenever they thought we were the least prepared. They were unfortmately aware that our ammunition was ruming short, as was plain from the shouts that came from their leaders when urging their warriors on to battle. No doubt the old Chief Berri was one of the causes of this, and for his traitorous conduct, strictly speaking, I might have had him shot. However, I could not bring myself to do this, preferring to keep him a close prisoner under lock and key.

That the blacks were now about to make a big attack upon us was evident from the shouting, blowing of horns, and beating of drums that could be heard all around us. To attempt to cut our way through and make for Sherbro or Bandajuma would simply have been to court disaster, as the bush was now strongly ambushed, and the roads blocked and stockaded. Besides, neither the men nor myself could have stood the strain of such a journey-perhaps contesting every yard of the ground. No, the only thing to do was to hang on in the hope that the long-expected assistance would crentually come. If it did not-well, there would be nothing left for it but to endeavour to cut our way through or die in the attempt.

What we did do, and how, by a mereiful dispensation of Providence, we got away, I will explain later. Meanwhile, let me resume my narrative of events.

At midday, in answer to a sentry who fired at and shot one of the enemy, we were at onee attacked. From all sides they eame at us, and poured in a hot fire from the surrounding bush. It was now a matter of extreme risk to attempt to cross one enclosure-a distanee of some trenty-five yards only. My men were well hidden and under cover, and placed at every point of vantagre. If, as I said before, the enemy had pulled themselves together, and rushed us in any numbers, the end must have cone at once. Mr. Riobinson, who had been doing good work with his rifle through one of the shutters of the 
honse, nuw called me to show me where a man was hiding on the ground, behind a $\log$ of wood, he thought, who had been suiping us steadily, but without result, for a long time past. I had just remarked to Robinson that he was not sufficiently covered, and pulled the two shutters together, when a bullet from our lurking friend crashed through the centre of it, and passing under my outstretched arm, and not six inches from Mr. Robinson's side, buried itself in the wall of the room behind us. A close call! After this he left that post, and sought for better cover.

I will not give all the details of the attack that followed, except to say that it was the sererest and most stubborn that the enemy had as yet made. How it happened that we kept them out, I do not know to this day. Half the onter side of our stockade was pulled down, and a hand-to-hand struggle had taken place between six of the enemy and four of our men, two of whom were wounded. Two labourers were severely wounded while rumning across the square to fetch water for the men, and my own coat had been torn, and my helmet perforated; while the Interpreter, who had in some mysterious way succeeded in obtaining a bottle of gin, was lying shut up in a slied, upon his back, dead drunk.

One incident I ought to mention : Lance-Corporal Macaulay, who was in charge of a post close to the riverside, espied some thirty or forty of the enemy swimming over it almost under our very eyes. We made great slaughter here, and although the shooting on our side was dreadfully bad, the other side nevertheless suffered sererely. I now learnt how extremely difficult it is to hit the head of a man with a revolver, even at close range, while swimming and bobbing in the water.

The enemy did not finally retire for five hours, and when at last they slunk away, I knew we could not with the few rounds that were left us stand another such attack. Sergeant Williams and Lance-Corporal Macaulay with four of the 
men came and told me the same, and suggested that the only thing left for us to do was to select a room and fight it out there until the last round was expended, and then use the bayonet. Such a thing could, of course, only have one ending, and I had determined to keep two revolver bullets for my own head after the last rally ; for to fall into the hands of these savages alive would have meant worse, far, than a thousand deaths.

I must own here to feeling horribly afraid. I could feel my heart thumping against my ribs, and although I knew that I was calm enough ontwardly, I felt terribly sick at heart. Moreover, I was, as I have said, very far from well, having had a high temperature for two days, scarcely any food, and no sleep at all. Mr. Robinson said to me, and I can recall his words as if they were spoken yesterday: "The next attack will be the worst one. I know these people, and they have gone to prepare and get more help. We cannot keep them off ; but before God they shall not take me alive!" and he swung the butt of his Martini into the air. While I was frantically and desperately turning over the situation and making up my mind what to do (on these occasions one does not have much time for this, but must act promptly) one of the labourers came up behind me and whispered in my ear, "Massa! nar boat!"

Like a flash the full force and meaning of those magic words came home to me. A boat! The next minute the fellow had informed me that there was a four-oared boat hidden round a bend of the river, not 200 yards away. He had know'n this all the time and had not had the sense to tell me of it! Verily, you need not look furtlier than a West African porter when scarching for a natural fool.

Here was a bit of luck indeed. If this boat had not already been discovered by the enemy, and we could obtain possession of it unperceived, we might yet get down to Sherbro. But was the boat still hidden there? Well we should soon know. 
It was past fire o'clock, and the sum, setting nore blood-red even than was his wont, as if to mock us in our troubles, prepared to hide himself yet once again in trailing clouds of glory from the strivings and the fury of the world whereon he daily razed. Darkness would directly be upon us, for there is no twilight in these latitudes. On my explaining what I wanted, four men readily volunteered to proceed, under cover of the darkness and our rifles, to bring the boat up-river to our position. At any moment the enemy outside might renew their efforts to get at us, and it was with the knowledge that life or death depended on the issue that we waited for our men's return. Ten minutes of breathless silence, and then we saw the outline of that blessed craft, left by Fortune's kindly hand, loom black upon the water. It was arranged that if the enemy did not then attack us, on my giving the signal, we should go down to the water-side, and embark as quietly and as speedily as possible.

We could still hear the MIendis shouting and jabbering in the forest all around. It seemed to me as if they were quarrelling amongst themselves about something - the division of the plunder, probably. No attack being made upon us, we crept down under cover of the darkness, with beating hearts and amid a silence of the dead. One by one we got aboard, Chief Berri, securely bound and gagged, being in our midst.

When all were in the boat, we found we were unable to push her off, and more delay was caused by sume of the men having to jump overboard and shove. Even the slight noise they made in doing this brought my heart into my throat. An attack now would certainly have meant our immediate annihilation, and even when, at length, we floated free and clear, it was but to find another trouble immediately confronting us-the oars had been forgotten! The labourer who had informed me of the presence of the boat was now so good as to rouchsafe the further information that the oars were lying under the verandah roof. Before we could get away they 

would have to be obtained. To do this it was necessary that some one should return to the factory-a matter of a hundred yards or so-and fetch them. Not a man would rolunteer for this duty; nothing, they said, would induce them to go back to that accursed place, althongh it had become a question of obtaining those oars or waiting to be cut to pieces in the boat. "Vestigia nulla retrorsum" was evidently the sentiment that animated every one; and really I could not blame the men, after what they had already gone through, for entertaining it.

It was beginning to rain, moreover, and a tornado was evidently blowing up, the dull rumbling of its alvanced guard being heard in distant booms on the horizon, while every now and then a virid streak of forked fire would, for the fraction of a second, light up the scene like lay.

At length the oars were obtained, and after sticking once again on to a bank we finally got clear. The rain-drops were by this time hissing fast npon the rippled surface of the river, and withont a rudder, and steering by the lightning-flashes, we pulled and tugged at those two blessed oars, in desperate haste to get away. For half an hour we went on thus, in a silenco rifted by the crashing of the warring elements above, and punctuated by the gasping of the rowers-of whom I was one -as we strained and panted at our work.

We were by this time soaked literally throngh and through, when, getting closer to the bank, a man sprang up like a dark phantom from the reeds that lined the water-edge and, shouting in his native tongne, "They go by the boat! the white man is going by the boat!" rushed frantically up the river-bank to join his comrades at the place we had so hurriedly racated. Some of my men jumped up with the idea of shooting him down, but, it being really too dark to take any sort of aim, and fearing the noise of firing wonld only warn our enemies and bring them down upon us, I forbade them, mider pain of instant death, to pull a trigger. 
A short while afterwards we heard the frantic yelling of the mob, now no doubt in full possession of the place, and in fact some of the howls that rose appeared to be drawing nearer, as if a party of these demons was following us up. However, partly owing to the deluge of rain that was descending and chiefly, probably, to a desire to stay and share in the plunder of the abandoned place, they must have quickly given up the pursuit. Before long the night was lit up with a red and vivid glare, which informed us that they were burning our old stronghold to the ground, dancing and shouting doubtless in their frenzied savagery round the roaring, crackling flames.

We still continned to row for dear life along our course, sometimes sticking fast on banks, sometimes running into trees and bushes. And so, at last, we pulled into the dawn. Every stroke now would make our safety more secure; because the further down we got, the wider grew the river.

As the light grew stronger, we glimpsed the charred and burnt remains of many a "factory" and store, while the natives spying us in the distance from the banks would sometimes try a shot at us, althongh the stream was now too broad for these to do us any harm.

Now that a portion of the strain had been relaxed, we felt (and probably looked) as wretched a crowd as one could wish to see. Half starved we were, and worn out, and unkempt; soaked to the skin by our many hours' exposure to the drenching rain, which set the men's teeth chattering like castanets. And still, in spite of their discomfort, my fellows found the pluck to talk and even to make a joke at times, laughing merrily at one another's plight as they peeled off their reeking jumpers and wrung the water out of them. Their red fez caps were mostly all pulled out, and sat on their woolly pates with all the grace of just so many dunces' caps at school. However, now that immediate danger was out of sight, their native minds appeared to be absolutely unconcerned about the future. Truly they are a 
wonderful race, from whatever standard they be judged, these big children of the West African bush.

By 10 a.m. we were close alongside York Island, and very soon afterwards I hobbled, as well as my stiff limbs would allow me, on shore, where I was met by $\mathrm{Mr}$. Cook, the agent of a leading factory (and a victim to the climate later on) with the remark, "Why, we heard you had all been killed!" However, he very kindly provided me with a change of clothes and some warm tea, and forthwith made me swallow many grains of quinine, while to my men he issued a double tot of of rum all round.

I then heard for the first time that the whole country was up in arms. Many factories had been burnt and looted, and an attack on Bonthe itself was lourly expected. On receiving this news I started off at once for the latter place, distant some one and a half hour's pull-leaving half a dozen of my men behind on Mr. Cook's urgent requisition.

On arrival, I was met on the Govermment pier-head by the Commissioner, Mr. T. J. Alldridge, and a crowd of other people, who cheered us heartily as we disembarked. Mr. Alldridge's greeting was much the same as Mr. Cook's had been-"Thank Grod! yon liave arrived; we heard the worst."

The other news I had received from Mr. Cook was confirmed by the Commissioner. The place was in a panic and in imminent expectation of an attack from the mainland; and, what was worse, there were few arms and still less ammunition available.

Thus terminated our defence of, and escape from, Kambia. Personally I was thankful enough to find myself alive with all my limbs intact. But for some time after these events I wonld start from sleep with the beating of the Mendi war-drums vibrating in my ears, and "cntting the air in twain with barbarous dissonance." Nevertheless, what with wild reports flying all about of the coming of the foe, I might well be 
excused for wond ering if, after all, I had not stepped from out the frying-pan into the hlazing fire.

Meanwhile, during two of the erentful days which I have just described, a dreadful tragedy was being played ont at Mawfé in the Boompé country, a description of which I shall reserve for another chapter. 


\section{CHAP'TER XI}

\section{THE RISING OF THE IIENDIS}

"Death in the front, destruction in the rear!

Such was the scene-what re. maineth here?

The sun, the soil, but not the slave, the same." Brion.

TWENT straight to the Commissioner's louse liere, where I met Miss Mary Mullens, a lady missionary who had managed to get away with her life from a place called Momaligi, where she was living alone. It was a providential escape for her. Dr. Jarrett, Assistant Colonial Surgeon, had volunteered with five police to go in a boat to the assistance of Mr. Hughes, the native Assistant-District Commissioner, who was residing at Bogo in the Imperri comntry. The boat was unable to reach Bogo and returned to Bonthe about midnight.

As I have stated previously, the place, which was inhabited by a large number of Sierra Leoneans, was in a panic. Tho Commissioner's house and verandahs, the police station and officers' quarters, were packed with people, many of whom had brought as much of their belongings as they were able to carry with them.

On receipt of my message from Kambia, which had reached Bonthe at daylight the morning after it was sent, namely, the 28th of April, the Commissioner engaged a German steamer, 
which had fortunately arrived the day previous, to convey the despatches to Sir Frederic Cardew at Freetown. Sherbro was now quite cut off from the outside world. Ninety miles distant as it was from Freetorn by water, with the mainland teeming with war-boys, the people here were in a most precarious position. What is more, there were rery fow arms in the place. As a matter of fact the Gorernment had but nine Snider rifles, and not much more than 750 rounds of ammunition, and unfortunately the European merchants in the place were even worse armed. Pumours kept coming in that a large number of war-boys were crossing orer from the mainland, and had sworn to sack and burn Bonthe. And what was worse still, treachery was feared. The very servants could not be trusted. It afterwards transpired that a great number of the natire employés in the European factories, and even a few in the Government serrice, were prepared to join the insurgents should they cross over, and bludgeons of iron, swords, machetes, and axes were discorered afterwards secreted in some of the cellars of the factories.

Bai Sherbro, the stipendiary chicf of Sherbro Island, and one of the ringleaders in the rebellion, resided at a town called Yomni, about five miles from Bonthe. He was sent for by the Commissioner, and came on the afternoon of the day of my arrival, and I was present at the interview. He denied, of course, haring anything to do with the "War," and asked for the protection of the Government. This denial was false, as he had been holding large meetings at his town, and attending others in the interior, for weeks before the outbreak.

A warm bath and short sleep almost pulled me together again, and about 1 p.m. the S.S. Gaboon arrived from Freetown, and a very welcome sight she was. She brought twenty Frontiers and some West India soldiers, under Major A. F. Dawkins, Northumberland Fusiliers. These had been hurriedly despatched by the Governor with orders that the Frontiers were to proceed at once to Kambia to endearour 
to effect my release. It is lucky they did not have to do so, sinee such a force would never have reached me by land or water, as the comntry then was, and would certainly have suffered most sererely, if not have been ammihilated.

From this time began one of the most terrible massacres and outrages in the annals of our Colonial history. The outbreak spread with alarming and almost inconeeivable rapidity. It is not quite correct to say "spread"; for when the preeoncerted day arrived the natives rose almost as one man. I was the first person attacked in the Bandajuma district: this was on the 27th of April, and from that day commenced a sequence of terrible murders, robberies, and wanton destruction of property to the value of many thousands of pounds orer the whole Protectorate, with the single exception of KoinaDugu.

To give a detailed accomt of all the horrors and sufiering that took place would be impossible in a work of this kind. The rising was so well and carefully planned, by a gigantic Yuira Poro, or "one word" war, that even the wires of the chiefs (and, of course, all other women) were excluded from the secret. Large secret meetings had taken place in the bush months before, when solemn oaths, sworn on the most deadly fetish medicine, the breaking of which would mean deatl, were taken. At these meetings the carefully planned details of the plot were discussed and settled, each chief and headman being responsible for his own party, who were in turn responsible to the paramount chief of their comntry. A great deal of money was spent by these chiefs in making sacrifices for the suecess of the rebellion, and in payment for the magic of the unscrupulons Morri men - who are itinerating low-caste followers of Islam, and who, by the mystic workings of their magie charns, wield a great deal of power over the superstitious minds of the people. In fact, a large share of the rising was, I know, due to the intluence of these people, who are as a rule natives of the country, but who have acquired a 
ecrtain smattering of Arabic and Mohammedanism. But more of them anon.

After months of careful plutting, a time and plan was arranged by which the whole country would know the exact day on which to strike. This was planned by the three principals of the whole movement, namely, Niagua of Panguma, a desputic paramount chief who held enormous power over a large area of country in the Panguma District; Gubmu of Boompe, the paramount chief of that country and a noted warrior and ruffian (and who, after the rebellion, suffered the extreme penalty of the law for murder); and Bai Sherbro of Conni, whose influence extended over a large area of the Sherbro Hinterland, and who, with Chief Niagna, was subseruently banished fom the country. With these three were, of course, a host of other paramount chief's and sub-chiefs, anongst the more importunt ones being Fa Kondo of Baoma, Honno of Gerihun, and Almami Senna Bundu.

They had no lack of support. They said they were going to get back their comitry, reintroduce slavery, abolish the House Tax, drive British rule and the white man from their midst, and murder every one who could speak English, or who wore English clothes. They intended to do more than this. They would loot every factory and store in the comtry, obtain an enormons quantity of slaves and wives by catching as many Sierra Leone women as possible, and arm themselves with the rifles and ammunition they would seize from the sacking of Bandajuma, Ronietta, Sherbro, and Panguma, and from the hands of the Frontiers stationed about the Protectorate, every one of whom they would torture or murder. And they were bound to succeed. Did not the Morri men tell them so? Had they not, by the aid of their Saraka (sacrifices), cajoled and pleased the spirits into bringing them success? Did not every town and village in the country have its "medicine" ready? There were not many white men, they said. A great number had already been killed by Bai Bureh, and the whites 


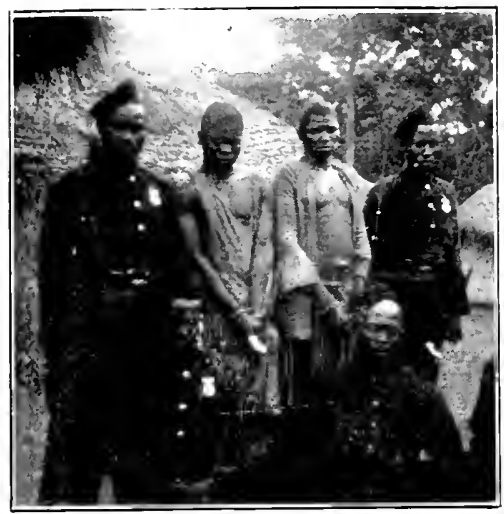

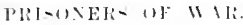

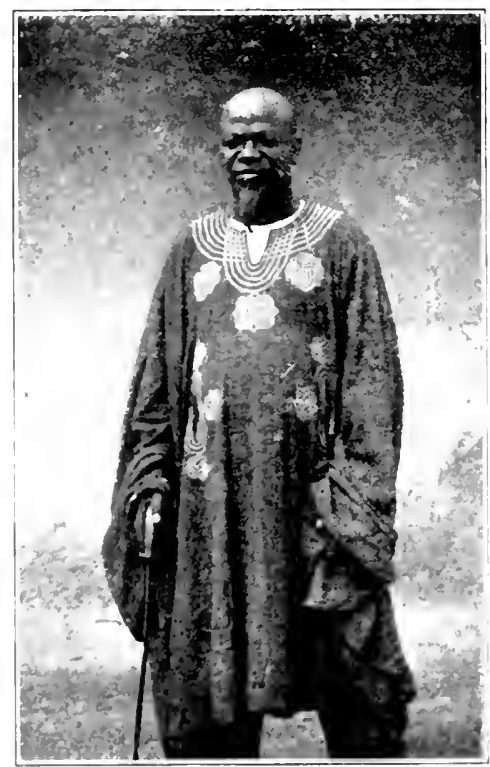

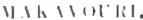

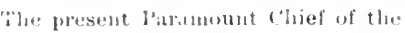
boumpre Cinntry. (1). IIn.

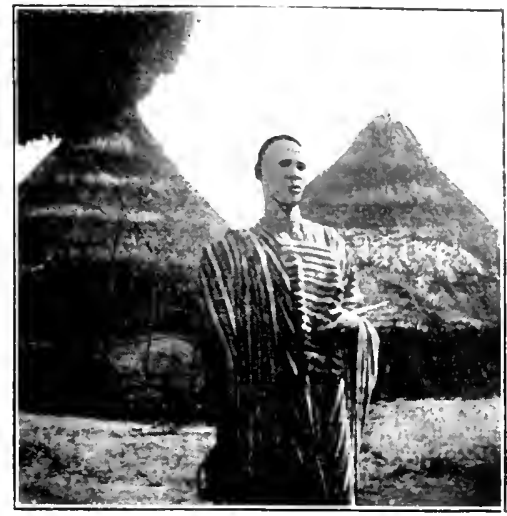

(II) E* H1)

(1) of the Leares an the rising.

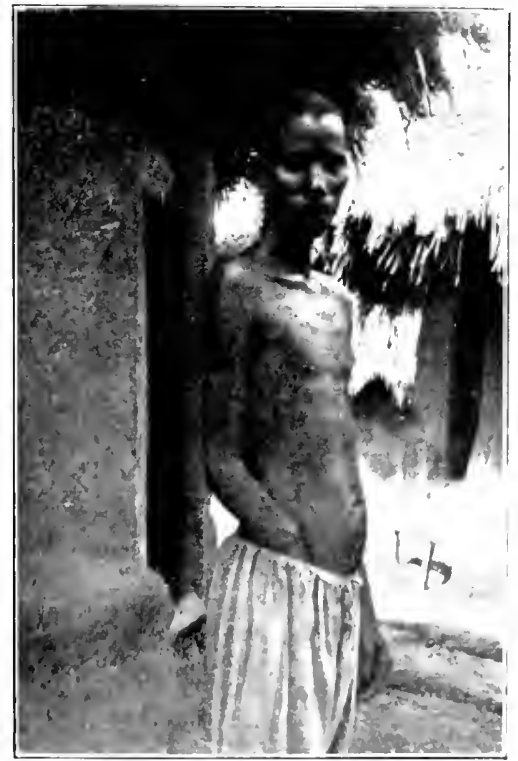

$141=5,11 \%$ III:1

Nitlir. 1, w.

1.1., 1:-

$(.1$ matir 2.) 

could never march about their country or follow them into the trackless depths of their forests.

The old "warriors" in the comtry were delighted with the prospect of murder and plunder that would follow the ontbreak. The sub-chiefs were equally so, and most of them readily and willingly took the oath; whilst the common people, the majority of whom believed implicitly in their fetish and their chiefs, were ready and willing to join them. The warnings of the more educated class of native were unheeded, and, in fact, scorned; those who wonld not take the oath and join would be murdered and sacrificed to the eause. Every one on the day had to join. Meanwhile, cutlasses and spears were sharpened, powder bought, cannon got ready, stockades built, rivers and roads blocked, and guns primed. Every conceirable thing that could be used as a weapon was secreted. Sticks with heavy knobs, pieces of iron, pikes, bits of wire, potlegs and slngs-all were converted into bullets. No one coming within the scope of their oath would be spared, and those who broke it wonld die; if not from the swords of their comrades, then from the effect of the terrible hari (fetish medicine) from which they believed there was no way of escape.

After many hidden meetings in the "poro" bush, and in the small faliais (villages) thronghont Merdiland, the "burnt leaf" was started. This is the emblem of war, and is sent with extraordinary rapidity from town to town and village to village. When a chief receives the burnt leaf, he immediately questions the messenger, asking "Brecal-m-bhui?" Which means "What news?" and the messenger tells lim ererything he knows concerning immediate events. The messenger is then sent back, and the recipient of the burnt leaf sends it on to the next chief by one of his own "boys"; and so it is passed from place to place throughout a very large tract of country, and in an incredible short space of time. Tery soon after the leaf has been receired, and the lour has come for action, a time is fixed for, say, the eighth day after the new 
moon. Then, on the arrival of the new moon, every chief, headman, and liruba (warrior) gets eight stones, and throws one away every day. When the last stone is thrown away, the rising begins. In this comntry each chief has his own "war." For instance, during the rising there were many "wars," and they used to join hands for one common object. At Kambia there were several "wars" attacking me. During the attacks on the stations in the Protectorate, several "wars" joined hands. After their olject had been attained these would go off on their own account, either to phunder or murder.

I have been at some tronble to ascertain who was the actnal instigator of the "burnt leaf." As I have said before, the rising was previonsly arranged by a series of gigantic secret meetings in the "poro" bush and elsewhere, the principal leaders being the three chiefs, Niagua, Bai Sherbro, and Guburn of Boompé. After nost careful inquiry, I think there can be little doubt that the burnt leaf first started from Boompé in the Bandajuma District, and was followed almost immediately by Niagua's leaf in the Panguma District, and then by a host of others. Anyhow, whoever it was, when the ball once started moving, no clief, be he ever so powerful, conld have stopped it.

As soon as the actual fighting began, the control of the chief orer his " boys" practically ceased. They got entirely out of hand, and very often small bands went off on their own account, looting and lilling, the plunder being divided and secreted amongst the Kruba of the gang and his followers, while a portion was kept for the chief to whom the party belongs.

It can readily be understood, then, in a country of this kind, where news is conveyed in a wonderful mamner over large distances, how quickly the rising spread from one end of the Protectorate to the other. The natives' great strength lay in their forest bush. To attempt to follow them there for 
any distance was quite useless, and I have, time after time, seen then suddenly bolt into this bush with a Fronticr following not ten yards away. Yet they have invariably managed to eseape.

One of the last oceasions on which this happened was unpleasantly impressed on my memory. I was on tour upcountry when one of the Court Messengers accompanying me eame up with his clothes torn, his face rmming with perspiration, and he himself very much ont of brealth. He panter out, "Dem people dem sabbe buslı too much, sar!" It appeared that one of my labourers, who no doubt felt he had had enongh of it, had bolted into the bush, with the messenger close at his heels. On coming up I found my box deposited in the centre of the path, with the kartar (a liead rest, often consisting of rolled leaves, etc.), carefully placed on the top of it. I recollect the incident so well, because we were unable to proceed without somebody to carry the load, and as we were then some distance from the village it was quite a while before we obtained another earrier, and got under way once more.

The natives are children of nature, and in nuany points closely resemble the wild animals of their forests. A Mendi can make his way through the thickest of foliage with ease, and with very little noise. From the custom of years they have learned to wriggle under creepers, twist between branches of trees, and aroid the impassable knots of entangled vine that are so numerous in these parts; while from the practice of years they can do it with extraordinary rapidity. A great number of the children are tanght when young how to go quickly and quietly through the bush, and those who are not so tanght are bound to learn from having to go into it nearly every day of their lives from their earliest years, following the elder boys who go hunting, wood-cntting, or farm-making. Also, even if it were possible to follow a native into his forest, it would still be extremcly diflicult to keep him in view. For 
here nature comes to his aid, as she does to that of nearly all animals who live according to her laws. The human inhabitant of the forest, with his naked body, harmonises closely with his surroundings. Like the tiger in the jungle, the deer in the momtains, and the snake in the grass, this wonderful provision of nature for insuring invisibility is strikingly illustrated in her unalterable laws, which extend even to savage man.

For months during the outbreak the people lived literally in the bush. All the women and children were there some time before, dwelling under temporary shelters made of bamboo sticks and leaves, set in places where it was almost impossible for us to find or follow them. Hunted fugitives lived there also, for the forest was a friend to all; and many owe their lives during this dreadful time to the friendly and secret shelter of its leaves and trees.

To resume: there was not much sleep for any of us during that Saturday night. The advent of the twenty Frontiers and West India soldiers was a great relief to the place, and took off mueh of the strain ; but such a force was totally inadequate to cope with the situation had Sherbro been attacked. Meanwhile, news of the most alarming nature kept on coming in of fearful massacres and destruction of property on the mainland, and of the coming and actual arrival of a number of the enemy and their spies in the island itself. All the European and other shops were shut and barricaded, while armed native and European patrols were formed to parade the streets or watch the roads leading to and from the outlying villages. I may mention that one of the Imperri chiefs was captured while landing from his canoe on the Island. He was conveying a message to Chief Bai Sherbro as to when they were to send the rar-boys to attack Bonthe. This man was, of course, made prisoner and detained.

Now and again a hunted trader would arrire, haring lost everything in his possession, and bring most harrowing tales 
of the doings on the mainland. The Sherbro mail-boat running between Bonthe and Lavana was missing, haring been abandoned by the crew and civil police when they found the rivers were blocked, and they themselves unable to proceed and chased by war-hoys. Beside the police and crew, there were passengers in the boat numbering abont sixteen, some of whom were women. Mr. Leech, of Manchester, who hat recently started business at Mopalma on the Upper Kittam, had had all his property phundered and destroyed, and had been picked up by the mail-boat before she was abandoned, having previously narrowly escaped with his life.

This party tramped along the beach, having landed at a place called Koronko on Turner's Peninsula. They intended to try and reach Bahol, about forty miles away, where they hoped to be able to get canoes in which to cross over to Sherbro. They were very soon again followed by the warboys, and had to discard nearly all their bundles, including the mail-bag, which was in charge of the coxswain.

After many hours or wearing tramping over the burning sand, the party became so exhansted that many were minble to proceed, and they split up into twos and threes. The sergeant of police was undoubtedly killed, as he fell behind and was nerer heard of again, and no donbt this was the fate of sereral of the others.

That night, about twolve o'clock, the police arrived and handed the Commissioner a bundle of money, amounting to $\mathfrak{E} 1,000$, the revenne that was to have been brought down by the abandoned mail-boat to Sherbro. These honest natives had been able, after discarding all their own little property, suffering dreadful hardships, being chased by war-boys, and losing half their number, to stick to the revenne and hand it over intact and correct to the Commissioner. Such magnificent behaviour needs no further comment. How many white men in their position wonld have done the same?

The next day the coxswain and some boatmen arrived and 
reported that $\mathrm{Mr}$. Leech was dead and could not be found anywhere. 'This proved to be incorrect, for after a great deal of suffering and many miraculous escapes, he had succeeded in reaching the sea-bar point, and, on promising a native an enormous bribe, was ferried over to Bonthe, where he arrived on the following Monday.

On Sumday a party, which was under my command, had gone ont in boats to endeavour to get news of Mr. Leech, and althongh we were fired upon from the banks, we kept too far ont for the shots to take effect. We hoped to draw Mr. Leech's attention, if he happened to be anywhere near, by the blowing of bugles and firing of guns, but we saw nothing except the dancing and shouting war-boys in the distance, and the ruins of the smouldering factories.

That night the sky was aglow for miles from the burning of the many houses on the mainland. Wre could see from the Conmissioner's house the wanton destruction that was being perpetrated.

The following day (Sunday) H.M.S. Elonde, under Commander P. Hoskyns, M.V.O., C.M.G., arrived. He landed fifty Bluejackets with their officers. These were quartered in the Court-hall, and were a great help in suppressing the panic that was now at ferer-point among the people. Meanwhile small punitive water expeditions were actively engaged in and about the Sherbro. The force, consisting of Bluejackets, Marines, West India troops, and Frontiers would start off at dawn and return at night. During these expeditions, the object of which was to endeavour to rescue any people who had fled and were hiding from the war-boys, we were invariably fired on from the banks of the creeks and rivers by concealed camnon, which the enemy used to load almost to the muzzle with powder and slugs. After returning the fire, a party would land and charge up the banks, hurrahing, and spike the cannon; and if there was a town near by, it would be burnt to the ground. On these oceasions the enemy never 
waited for us, but having had time perhaps to load and discharge their camnon a second time, they would abandon it and flee to the bnsh.

An attempt was made by one of these parties to resene Mr. Hughes, who was reported to be a prisoner in the hands of the Imperri chiefs. With that object an expedition, consisting of some seventy Bluejackets, fifty Marines, thirty West India soldiers, and forty odd Frontiers-- the whole under the command of Captain P. Hoskyns, R.N., M.V.O., C.M.G.--started by water for Bogo, intending to march overland to Imperri town the headquarters of the Imperri country, where Mr. Hughes was supposed to be detained.

That night the party slept on board H.M.S. Blonde, and the next morning we embarked in a flotilla of boats and were towed by the steam pinnace up the river. While proceeding in this way, we were several times fired npon by the enemy, and on landing at Bogo we conld hear them in the bush all around us. A cohmm of mareh was speedily formed, of which twenty Frontiers, under my command, constitnted the advanced guard. No sooner had we commenced our march than we were strongly attacked on all sides by an enemy concealed in the thick bush, with the result that a couple of my men were badly hurt by shigs. The further we proceeded the more numerons did they seem, judging by the noise, to be ; they remained, however, so perfectly concealed that my men were never able to get at them. The bush at this point became almost impenetrable, and on nearing a burnt-ont fakai (small village), we were fired on from both sides simultaneonsly without being able to return a shot.

When we had been marehing upwards of an hour the commander, on discovering that the enemy was endeavonring to cht us off from our boats, which had been left in cliarge of a few marines, decided to retire upon them for the time being. At this time Imperri town wonld he some seven miles away, althongh our local guide informed us that it was 
distant a good ten from where we were. We learnt later to accept these native estimates of mileage with a considerable reserve, seeing that they were invariably dictated by a desire on the part of the person naking them to postpone bringing us into anything like direct contact with an opposing force.

I now volunteered to go forward with thirty Frontiers, and try to reach Imperri. But to this suggestion the commander did not see his way to agree; and, indeed, there was some necessity for returning lest our boats themselves should be attacked, and our means of retreat cut off. During the homeward journey I was conversing with Commander Holmes of the Alecto, when a man hidden in the bush not ten yards away fired a cammon point-blank at us, causing us almost to iump out of our skins by the deafening report at such close quarters. Close as this was neither of us was hit. Eventually our force reached Sherbro, but unfortunately without having achieved its object, the rescue, namely, of $\mathrm{Mr}$. Huglies.

Whilst on the subject of these little land expeditions I may appropriately recall an incident which gives, I think, a good idea of how narrowly our every movement was watched by the vigilant enemy. We had landed near one of his towns, and having cleared it out, had, as usual, fired it. Most of our men, including the West Indias and Frontiers, were scattered about in small parties, foraging for loot. Dr. A. F. M. Berkeley, District Surgeon, who had gone far up on one side of the place, found himself on a path leading directly into the bush. With him were three Frontiers and two or three West India soldiers. Suddenly, forth from the underwood leapt a naked warrior, brandishing a long sword. The doctor had only just time to present his revolver at the man, whose spring had landed him not five yards away, and pull the trigger when-his pistol missed fire! He instantly flung his weapon in the other's face and turned to r'm for dear life. Ill-luck and the Mendi both pursued him. He slipped and 


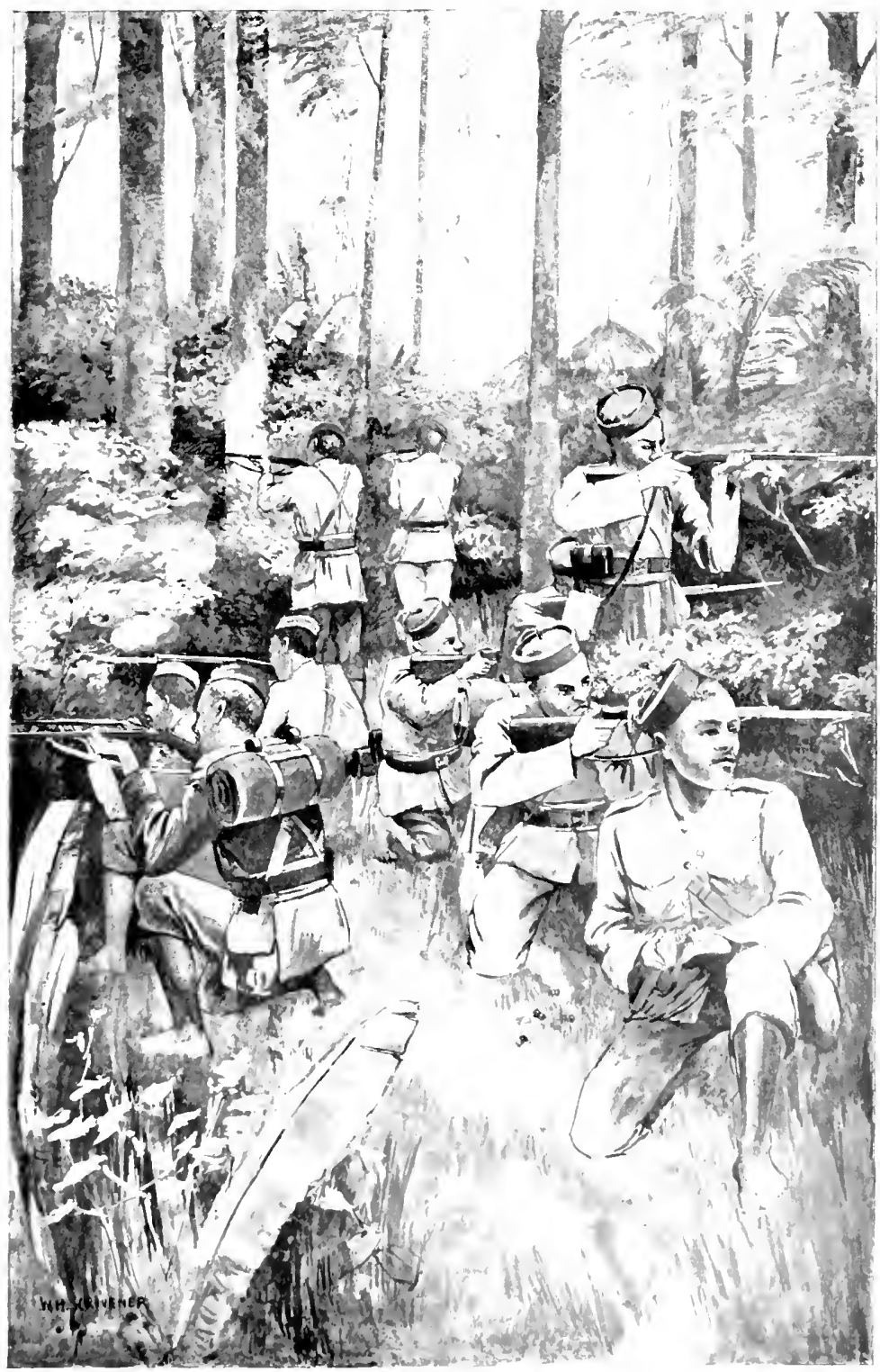

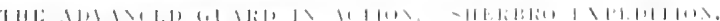



fell on his knees, and his huge antagonist, only momentarily stopped by a shot from Captain Stewart of the West India Regiment (who had been a spectator of the scene), had already shortened his sword-arm in order to decapitate his victim. In another moment Dr. Berkeley would have certainly been killed, when Lance-Corporal Brimah Windai, a Frontier, by a well-aimed shot dropped the fellow in the very nick of time. The whole incident had occupied but a very few seconds, but it created something like a panic for the moment among the men, and I saw several of the carriers and soldiers begin to make tracks for the river-bank. There is nothing, we know, so infections as example on oceasions of this kind. I was at the further end of the place at the time, and the town was burning merrily, but when I witnessed the general stampede I found myself, almost before I was aware of it, ruming too, thongh I pulled up on ascertaining the real cause of the disturbance. 


\section{CHAPTER XII}

MURDER OF MIR. HUGHES AND MASSACRE OF MAWFÉ

"The hand that mingled with the meral, At midnight drew the felon steel! And gave the host's lind breast to fecl Meed for his hospitality.

The friendly hearth that warmed his hand At mirlnight armed it with a brand That bade destruction's flames expand Their red, and fearful blazonry." Massacre of Glencoe.

THE fate of Mr. Hughes, of Imperri, was terrible in the - extreme. He was still alice upon the day that we started to rescue, or to attempt to rescue, him. But he was then hidden in the bush, and even had we succeeded in getting into Imperri town we should never have found him.

The story of his capture and death is, as I have said, a sad and a rery pitiful one. At the rery commencement of the outbreak Hughes was made a prisoner, together with his wife, whilst those of his servants who had not already made their escape were instantly put to death by the Mendis. Poor Hughes was first tied and then cruelly "stocked." For sereral days he was kept bound, just sufficient food being given him to keep the life in him. Now it had happened, at times, that in his official capacity he had found himself compelled to inflict certain fines upon those brought before 
him. The people were not slow to remember this now that they had him in their power. They exacted a revenge that was fiendish in its barbarous ingennity. Every morning at a certain time the scoundrelly chicf would hold a sort of mock court, taking care to have Mrs. Hughes placed in a position where she would have, perforce, to be a spectator of all that passed. Then Hughes would be brought forward, and after some farcical procedure arranged for the enjoyment of the delighted throng of savages who gathered round, the chief would order his wretched prisoner to be fined one or two pounds as the case might be. A grinning black, armed with a blunt sword, would then step up and, in the very face of his agonised wife, would saw off one or two of the poor man's fingers. When all his fingers had been severed his bleeding hands were cut off at the wrist, the devil who pretended to act as magistrate informing him that this was merely the equivalent of a five-pound fine, snch as Hughes himself had often inflicted upon them. Day by day lie was subjected to further torture of a description too horrible for words, until he finally became a mere mass of quivering mutilated flesh. And day by day, too, his poor wife was brought in and eompelled to witness all those growing horrors nutil at length, when the end came and her husband died from loss of blood, the wretches who had her in their power did her the only kindness left, and cut her throat from ear to ear. It is questionable if any political adjustment called a "pacification," or any punishment inflicted by us on the ringleaders in this rising subsequently, could possibly atone for crimes like those. Surely the British had been justified had they wiped out every black the country through. There is no element of doubt either as to the actual commission of this atrocious picee of brutality. I myself had the details at first hand from a Court Messenger named Cole, who was a mative of tho place and hininself an eye-witness of the revolting seene.

Nor does the tale of horrors stop here. T'ragedies worse 
even than this in their cold-blooded ferocity were almost daily enacted in this devil's cess-pit during that awful time-dark deeds that make the blood run cold even to think of : acts so utterly horrible, so absolutely hellish, that Nature's very self might well blush for Creation. Verily, here in West Africa, you have, epitomised, the sentiment of that grand old missionary hymn of Heber's: a land "where every prospect pleases and only man is vile."

In connection with the outrages perpetrated upon innocent people at this time the name of the chief of Bambaia stands out for peculiar execration. This man was literally a fiend in human shape. In the evidence brought against him at his trial following upon the termination of the ontbreak, it was proved that he had caused a deep well to be dug into which, after subjecting his helpless rictims to all the nameless tortures that his black heart was capable of conceiving, he had their bleeding bodies thrown as a saratia (sacrifice) to his gods.

Reverting for a moment, in concluding this portion of the narrative, to Hughes's fate, I may just state that an expedition went up to Bogo later, which was accompanied by Mr. Alldridge, the Commissioner for the district, who during the outbreak had worked night and day and had heary responsibilities. He was able to discover and identify Hughes's remains, and had them rererently collected and brought down to Bonthe. Here they were interred with military honours, the officer commanding troops and several other officers attending the funeral, at which fifty men of the West India Regiment escorted the coffin to its last resting-place. The remains of Mrs. Hughes, who was no whit less a martyr than her husband, were never found.

One of the largest and most important centres in the Protectorate not being a seat of the Government is the pretty and picturesque town of Mawfé, in the Boompé comtry. This place is situated on the sonth side of the 
beantiful Big Boom River, ronghly twenty-eight miles from Bandajuma and nineteen from Kambia. It is the centre of a thriving trade, and there are many stores and "factories" on both sides of the river. On the opposite side, or left bank, lies Mobongo, while two hundred yards lower down is the little trading station of Sumbuia.

Manfé, before the rising, was a very large town, in which a number of educated people from Sierra Leone resided. It had its stone chapel and school, which were well attended by the ehildren of the Sierra Leoneans and others resident in the neighbourhood. A brisk trade was always going at Mawfe, for in the rainy season the river was narigable for fairly large craft to Sherbro, and a great deal of produce used to be received here from the interior. The Big Boom Rirer in the "dries" was magnificent, and many a time I have bathed in it after a long march while touring in that part of the country. It runs elear and sparkling orer a sandy and rocky bottom, while just above the town the way is barred by a mass of huge rocks and boulders stretching right across from one bank to the other and forming a roaring eataract. The banks on both sides are lined with beautiful tropical vegetation, while here and there, dotted amongst the noble palms and other giant foliage, peep the conical thatched roofs of the villages. Sometimes these stand out in bold relief at the very water's edge when a natural break in the regetation allows it. The banks of this part of the river are from eight to fifteen feet in height, and, as a rnle, very stcep.

In the rainy season the river is between three hundred and fifty and four hundred yards wide, but during the "dries" it shrinks to half that size, leaving long stretehes of sand exposed along its bed. I recollect, on my first risit to the interior, this river at Mawfé was one of the largest African waterways I har seen. The view as it struck me then has always been fresh in my memory. The density of the forest was overwhelming; the strange and brilliant-plumaged birds 
darting here and there, the bright sumshine that made the water flicker and sparkle like silver, the native dug-outs, swiftly and silently crossing and re-crossing, with their dusky paddlers, together with the air of freedon that was around one-all helped to form a fascinating and interesting picture. One thinks when gazing at such scenes as these, surrounded and enwrapped by glorious nature, how beantiful the world is when untonched by the scheming hand of man.

"To sit on rocks, to muse o'er flood and fell;

To slowly trace the forests' shady scene,

Where things that own no man's dominion dwell

And mortal foot hath ne'er or rarely been."

Besides being an important and busy trading centre there were small barracks built just outside the town, in which resided a sergeant and nime Frontiers, who were inspected from time to time by an officer from Bandajuma. Shortly after my arrival at Kambia rumours had been reaching Sergeant Smith, who was then in charge of the detachment at Mawfé, of impending trouble, and the principal merchants and traders in the town sent a letter to me reporting the rumours that were current and asking for further reinforcements. I never received this letter.

On April 27th news reached Sergeant Smith that we had been attacked and killed at Kambia, and that same day he wrote to the officer in charge at Bandajuma, but this letter never reached him either. The sergeant now very foolishly, on the representation of the people, quitted his barracks, which were in a fairly good position for defence, and took up his abode with his nine men in the two-storied wooden residence of Mr. Allen, an old Sierra Leonean, who had lived for years amongst the natives, and who, as I have said before, was continually rendering them assistance and doing little acts of kindness among them. Into this house flocked most of the Sierra Leone men, women, and children, with as much of their property as they could carry with them. 
On April 28th, at about eight in the morning, the town was attacked by a number of the Boompé people. The church and stores were entirely destroyed by fire, and the Sierra Leone men, several of the women, and all the little children, who did not happen to be with the Frontiers or in hiding, were massacred. Those women who were not killed then and there were stripped of their clothing, tied, and taken as slaves.

For the whole of that day Sergeant Smith and his men defended the house and fought in a brave thongh reckless way. They had already fired away an enormous amount of ammunition, for they had no white officer to direct them; and owing to the number of people in the place, and also for want of careful husbanding, their water was soon exhausted and they began to suffer terribly from thirst. They had succeeded in driving away the enemy a number of times, but they always returned with reinforcements. By three o'clock the men recognised the serionsness of the situation. They were badly in want of ammunition; they were parched with thirst; three of them had been wounded, and some had not been able to resist the offers of the Sierra Leoneans of sundry drinks of gin. The enemy were by this time like a mad, howling pack of wolves, frenzied from their taste of blood and reckless with the boldness acquired from raw liquor, which they liad snatched and consumed from the burning stores. Their tactics were now to burn the defenders and the helpless band of women and children out of the place. After several attempts they succeeded in setting fire to the woodwork forming the basement of the liouse. The hungry flames leapt up, and soon, licking aromd the wooden structure, had cauglit the floor beneath. The house became instantly filled with smoke, which wreathed in yellow eurling clouds into every room and out of all the windows. The desperate inmates, realising their position, rushed shrieking to and fro; the ammunition was now almost finished and the rifles 
burning hot from constant firing. Mothers looked with agony upon their crying babes, and some, more desperate than the rest, seized knives and put the little ones out of their misery, and then cut their own throats. Many of the inhabitants in that doomed place implored the sweating defenders on their knees to shoot them down.

Next, Sergeant Smith, foreseeing the terrible end, a thousand times worse than death, at the hands of the furious mol beneath, seizer his burning rifle, placed the muzzle in his mouth, and pulled the trigger. The lance-corporal inmediately followed lis example.

The fire by this time had fairly caught the wooden place, and the heat haring become unbearable, a rush was made for the stairs and doors. Some, unable to find an exit, flung themselves in their haste from the windows, to be met beneath by the furious naked Mendis. Others succeeded in graining the yard, only to be caught like sheep and hacked down then and there. Every child was spitted. Every man who was not hilled at once was tied and had to die in slow torture. Fires there were ready with stakes driven into the ground. To these some of the unfortunates ware dragged, having first been deprived of an eye or limb. To these stakes they were bound or chained, and slowly burned to death, with a ring of maddened fiends jumping and howling round them and laughing at their screams of agony. One young man, a prosperous trader, whom I had seen and known only two short months before while passing throngh this rery place, was tied and taken to the river-side. Here they cruelly eut and jabbed him with their swords, and when he called out from the pain a natire skewer was run through either cheek, and in that position he was left for many hours, to be afterwards cut to pieces and his remains thrown in the river.

Hardly one escaped that fearful day. Every Frontier was cut down, and the place ran red with blood. The wretches, in their lust for crime, did not content themselres with mere 
killing, but derised most gruesome tortures. Half-dead victims were thrust head first into drains. Some were roasted alive, while one man was hung up by his ankle from a tree and flogged to death. I camnot describe one fourth of all that happened, for many things, too shocking to put on paper, have since been told me by eye-witnesses of the scene who had got away and hidden in the bush before it was too late.

I came up with the colnmn later en route for Bandajuma, and the remnants of this tragedy were all before our eyes. The officer commanding the column, in one of his despatches upon the operations, says: "We occupied Mawfé next day; the town was found to be in ruins, and most shocking sights met our eyes on all sides. Numbers of corpses were lying about in all dircetions, most of them charred, and showing evident signs of the inhuman treatment the unfortunate Sierra Leone traders had met with."

When the Mendis har finished their dreadful work, dancing and drunken orgies took place all over this part of the country. The fetish Morri-men had indeed spoken truly, they said, for so far in the way of butchery and murder the insurgents had been most successful. Yet, to paraphrase the poet:-

"Ill fares the land, to hastening ills a prey, Where villanies accumulate while men deeay. Prinees and ehiefs may flourish, or may fade, A breath has made them, and a word unmade. But those brave souls, who died for England's sake, When they're destroyed, who next their place will take?" 


\section{CHAPTER XIII}

THE HASSACRES

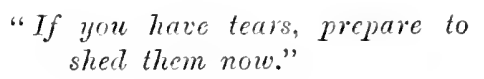

ShaKespeare.

I'T is necessary, in order that the state of the country at this 1 time, and the practical methods adopted by the natives in the fulfilment of their oath, may be thoroughly understood, to turn from the more honourable practices of war to those of brutal massacre and murder.

As has already been stated, an enormous area in the Protectorate was affected by the rising; indeed, every district with the exception of Koina-Dugu was up in arms. This disaffected country would cover an area of considerably over twenty thousand square miles. From the very commencement of the rising, until its termination, murders and massacres were daily being enacted throughout this rast tract of territory.

To attempt to give anything like an adequate description of all the horrors of this time, and the number of Englishspeaking people who were put to death in cold blood, would be a Herculean task, and one that is quite beyond the scope of any pen of mine. The total number of deaths is unknown, but I can safely assert that one thousand human beings at least must have been killed, while a great number of these 
were barbarously tortured to death. From my own personal investigation conducted on the spot, I have obtained the names of 675 murdered persons, as well as reliable evidence as to the horrible ways in which a great many of these people met their deatlis at the liands of the aborigines. Simnltaneously the butchery was daily being carried on in almost every corner of the affected area. The districts of Ronietta, Imperri, Sherbro, Panguma, and Bandajuma, could each reveal a story of almost muparalleled barbarity if the flood of daylight were thrown on to the hideous transactions of the first three months of the rising.

Most of the black people murdered belonged to Sierra Leone. These were, all of them, persons whose only language was English, who were edneated Christians, and who held respectable positions in the Protectorate. The list included merchants, traders, agents, missionaries, and clerks.

Mr. William W. Lewis, nephew of Sir Samuel Lewis, C.M.G., the unofficial leader of the Bar in Freetown, was canght by the war-boys at a place ealled Bo on the Boom River. He was eruelly tied and taken to a small village called Biama, also on the Boom River. Here, after having been kept without food and water for four days, he was held down and his throat ent from ear to ear. Mr. R. T. Collier and his son, Mr. Nathaniel Collier, both well-to-do merchants owning a lot of property in the Protectorate, together with their elerk, a man ealled Joe Cole, were killed in a particularly brutal manner at a place called Gorbu. Mr. Collier, senior, had resided for many years among the people, and had mate a good deal of money. He was a personal friend of my own, and was very good to me when I was suffering from fever. When the war-boys eanght lim and his son he offered to give them everything he possessed if they wonld kill only him, but spare his boy. 'The Mendis took all three, seenrely tied, into the bush. They then began to ent them abont. When the son fell on his knees and began to pray for deliverance or 
death, a sharp skewer was run through both cheeks, and he was left with gaping and bleeding month in this position. His father had meanwhile been tied seeurely with his back against a tree in order that he might see the sufferings of his son. Then, bit by bit, they began to sever the limbs of the lad; and when his feet and hands had been cut off his head was severed by a cutlass. Mr. Collier next saw the murder of his clerk, until at last his own turn came, and the old man, by this time driven half erazy by the spectacle of the sufferings of lis son, had his throat ent.

Then eame the killing of Mr. Robert B. Wilson, of Toma, also a prosperons trader and an aequaintance of my own. He attempted to escape at the eommencement of the ontbreak, hid for eight days in the bush, and was found in a starving condition by a party of war-boys at Manno, on the Kittam. He was taken to Tallia, a town in the Small Boom comntry, and after being made to suffer further nameless eruelties, was set upon by seren men armed with cutlasses and ent to pieces.

Mr. O. Cole, of Barmani on the Boom, who was agent to the French company, and in charge of their factory there, was taken to Harhun, the chief town of the Bekowar eountry, and there was slowly put to death, in the presence of his shrieking wife, each war-boy cutting him once with his sword. His wife was afterwards murdered in the same place. Mr. Clarke, who resided on the Kittam River, and who was agent to the European firm of Messrs. Paterson, Zochonis \& Co., was also killed at Tallia in the same way and in the company of a constable of the Sierra Leone Police.

Amongst the many killed at Mawfé were Mr. Trinity and his wife and ehild, Mr. W. R. Allen, Mr. F. S. Powells, Mr. Wallace, Mr. W. Thomas, Mr. Peter Williams, Mr. C. Maeaulay, Mr. A. Paris, and many others. All these were merchants of some position and influence belonging to Sierra Leone, and every one was most brutally and horribly 
maltreated and murdered. At Mattru, on the Jong River, Mr. H. V. Koker was slowly put to death by being ehopped a little every day, until after five days of awful suffering the end eame.

Mr. Kent Cole, a prosperous trader, was ehopped to death at a small faliai (village) near Grima, in the presence of a large erowd of jeering and dancing war-boys. Mr. Goodman, of Moeolong, an edueated young Sierra Leone elerk, was first tortured by laving lis tongue cut out, and then being deeapitated.

The Rev. C. H. Goodman, a European minister of the United Methodist Free Church, who was taken prisoner by the Boompé people, had a marvellous eseape after going through a terrible time. I cannot do better than give some of his statements made before the Royal Commissioner in 1898. Mr. Goodman had been warned that a party of war-boys was coming into his town, and told not to go into it. He says :-

"Those who first tried to go into the town were met by the war-boys, who flogged them with entlasses. Mr. and Mrs. Johnson (Sierra Leoneans) were stripped naked in the road, at a short distanee from the gate of the town. They struek Mr. Johnson on the face with a entlass, so that his nose foll off the next day. Another agent and his wife wore already hidling in the town. Myself and another were left on the mission station, and hearing a noise, started to go to the town to defend the others. The 'boys' then left Mr. and Mrs. Johnson, and turned towards the mission. I went into the bush behind the mission house. They eut out the doors and windows with their eutlasses and plundered the houses. In the crening I erept back, but went back again, as there were people about. They burnt two houses that night and two others at the end of the week. The mission house itsolf was a frame building on stone piers. Residing in the house were myself, Mr. and Mrs. Johnson and their ehildren, Theo 
Roberts (a native agent), his wife and a sister, Mrs. George Pratt, the Sierra Leone carpenter ; another agent, Campbell, lived near, and Vincent the sawyer. They were all Sierra Leone people. A Sierra Leone man who had come to me for medicine was also killed. The war-boys heard I had gone to the town and came and demanded that $I$ should be given up. I was being sheltered at the time by Chief Sandi, who begged me to go out of the town, and I went, disguised as a sick woman. I went to one of Sandi's houses near the town.

"About 4 a.m. they took me to the bush, and I remained hidden all day. At night time $I$ was brought back into the town by the chief's people. I remained in that house until Friday morning under the chief's protection. On Friday morning I received a message that Sandi wished to see me, so $I$ asked where he was, and went outside to look for him. I could not find the messenger, so, walking towards the barri (native court-house) I called Sandi's name. He did not reply. The Boompé people who were present got up, took me in charge, two in front and two behind. I was ordered to come to Tikonko, and afterwards to Boompé. They took me there, and when $I$ was about one and a half miles from the town, they stripped me almost naked. They divided my money and wateh and what I had in my pockets, and offered my clothes to the people, but thcy would not take them. Having got to Boompé, they judged my case. The whole town took part, the King being in the chair.

"Mr. Johnson was killed by the Tikonko people, and Mrs. Campbell was caught and killed by the Boompé people. I believe I saw Mr. Johnson's body."

Mr. Goodman, although he suffered much while a prisoner in the liands of these people, was not killed. They looked upon him as a God's man, and this saved him. His was indeed a miraculous escape.

Nearly every one else who fell into the hands of the natives 
suffered death. Therc are, indeed, a few rare instances of people being warned by a friendly native, and managing to secrete themselres in the bush and so escape. Mr. A. N. Morrison, the First Clerk in the Bandajuma District, is a case in point. He has on sereral occasions told me of his experiences while a prisoner in the hands of the Mendis. Mr. Morrison was, before he entered the Government service, a merchant at Mano Bagru, in the Sherbro country. At the time of the ontbreak he was staying at Damballa with his father, who belonged to the United Brethren Mission at that place. Damballa is some two days' journey from Kwalu, which was the headquarters of the Ronietta district. On the 29th of April Mr. Morrison left Damballa for a town called Banju. When he arrived there he was canght by the warboys and stripped naked. He was 'then handed over to two men armed with swords and ordered to be killed. The chicf, however, was absent from the town, and it was agreed that the murder should be postponed until his return. An old man, a pure-bred Mendi, who had lived for years with Mr. Morrison's father, begged the men guarding him to let him go. A bribe of six country cloths was offered them, and they took Mr. Morrison to the place where he had left his cloth, and while the cloth was being divided among them, he ran into the bush with the boy and remained there in hiding for a month, going through many adventures and nearly being discovered several times. Mr. Morrison's father, who was also caught, died from exposure and rough treatment.

One of the worst murders that took place during the whole outbreak was the killing of Mr. T. Johnson and his sister, a girl of eighteen, who were caught liding in a village called Deparli, in the Jong country. As soon as they were taken prisoners they were tied together, stripped naked, and terribly floggred. They were then made to walk to Tihun in the Small Boom country, several hours' journey away, where they were brought before the ehief, a man named Vandi, who 
immediately ordered them to be killed. They were then flogged again in the presence of a large number of people, and had to walk back, in charge of a party of war-boys, to Deparli. When they arrived there, the war-boys tied Johnson to one tree, and his sister to another, both in view of each other. A man then appeared with a knife, and after some difficulty succeeded in cutting off one of Johnson's ears. Miss Johnson's ear was also ent off. Then several ruftians held first one, and then the other, down and slit their tongues. In this position they were left for some hours, and then conveyed into the bush and flung into a fire which was made ready to receive them. Whether they were dead or not when this happened I could not ascertain. Let us hope they were. There were three other numders committed in or near this village of Deparli, and the perpetrators of them have unfortunately never been canght.

The murders which took place at a large town called Rotifunk are too horrible for a detailed description. At this place, amongst the many who were killed on the 3rd of May, were an Ameriean gentleman, two American ladies, and two English ladies, all of whom were tortured to death. These people were living in the mission-house at the time of the rising. This was burnt to the ground; and they were all, with the exception of one, killed in a most terrible and awful manner. All the ladies we a stripped naked and outraged, and left in the burning sum for hours to be gaped at by thousands of dancing war-boys, a great number of whom were half-mad from drink, and capable of anything. The youngest lady was kept a close prisoner by the chief. He wished to make her his wife, but she had the strength of mind and the pluck to refuse, and was consequently beaten and tortured. She was kept a prisoner for eiglit days, and then handed over to a party of war-boys, who took her into the bush; and there every effort was made to induce her to change her mind and marry the clief, but without avail. The 
chief's wives were sent to argue with her, and they treated her very cruclly. After being kept a close prisoner in the bush for three days, she was taken back into the town and brought again before the chief. A large crowd of people had gathered to see the white woman, and a sort of trial took place, the chief himself presiding. At the conclusion of this it appears as if some bargaining and arguing took place among the "big men" about the girl, and several offers were made for her. Still refusing to accept the chief as liusband, or to marry any other man, she was kept a closely guarded prisoner in a small hut on the outskirts of a farm inside the bush. The chief's second wife was sent to look after her, and I understand that during the time that she was there she was treated fairly kindly by this woman. At length she was again brought before the chief; and on her persistent refusals she was flogged and tied. Finding that everything that he conld do was of no avail, the chief lost his temper, and calling to some war-boys, ordered the girl to be killed. They were to kill her, but they would not do it too quickly. She was then led away into the bush, bound, and stripped naked.

A man named Robert Taylor, a carpenter by trade, who was present during this time, most graphically deseribed the scene to me. This man, althongh a pure-bred native, was fairly well educated, and at the time hidd to pass himself off as one of the party joining in the "war." He could be nothing else, therefore, than a horrified spectator of the seene. Ho did not see the actual murder in the bush, bnt he saw the girl led furth to die. He sair: "I heard the screams from the bush, and the woman calling out to God to let her die. They cut her a lot with their swords, and made a lot of noise. There were plenty of war-boys present. The sereaming went on for a long time. They did not kill her all at once. I felt very meli afraid and wanted to beg for the white woman. But I dared not say a word, or they would have found out that I knew English and killed me." 'The girl was 
disgracefully outraged, and then chopped down with a machète, some of her bones and hair being taken and made into "strong medicine." And this foul deed, too awful to be described in full, was perpetrated in the beanty and grand solitude of an African forest. The leaves all round the spot were splashed with blood, and the ground was tramped down with the prints of many naked feet. Yet after that foul deed had been committed, the sun continued shining in the hearens, and the birds sang close by as they flew from tree to tree! Nature seemed all mmored at this grim tragedy. One would almost hare expected the rery earth to shake, and the sun to put out his light, after witnessing such dreadful scenes!

"Flows there a tear of pity for the dead? Look o'er the ravage of the reeking plain; Look on the hands with female slaughter red Then to the dogs resign the unburied slain. Yet are thy skies as blue, thy crop as wild, Sweet are thy groves, and verdant are thy fields."

The other ladies and gentlemen were killed within sight of each other, and long before the terrible end came, they prayed and longed for death to free them from their dreadful sufferings,

Mr. and Mrs. M'Grew, both Americans, were foully butchered at Kama in the Ronietta District on the 17th of May. They lived for many hours, during which time their sufferings must have been too terrible for words, when at last death came mercifully to their relief. These people had for months past been doing good and excellent work among the very natives who cut them down. Kindness they had showed freely to all. The sick had been risited and treated, the poor assisted, and the children taught. Small acts like these were of daily occurrence, and there were not many people living in the vicinity who had not received from these good people some benefit or other, either directly to themselves or 
to their friends or relations. And yet, when the outbreak came, these very beneficiaries were the ones who helped to slay and torture them. We, as Christians living in the twentieth century, cannot understand such base ingratitude. But " can the Ethiopian change his skin, or the leopard his spots?" I trow not!

In comnection with the above I cannot do better than quote an extract published in the Daily Cloronicle in June, 1898, from a correspondent who was on the spot during that time.

"We have had no sleep for the past four or five nights, expecting the Mendis to rush us from the hill-sides. When they made their attack on Rotifunk, they captured four American mission ladies, who had got about a mile and a half from their mission in their flight to Songo tom. They stripped these ladies of all their clothing, and marched them back in the buming sun to the house they had just escaped from. After cruelly ontraging them, they put them to death and mangled their bodies in such a manner as cannot bo described.

"Another lady, who was down with fever at the time, the fiends tied up in barbed fencing wire, thus piereing lee to death. The men they captured they mutilated by first entting off hands, then arms to the elbow, and afterwards at the shoulders, legs being chopped oft piecemeal in similar fashion, after which the trunk was hacked in two, and the head severed from the body and placed on a pole. These poles were set up in fields, portions of the body being scattered along the roadway and in the bush. The Mendis, indeed, sent into Sherbro several baskets of chopped up human remains, both of whites and blacks."

Throughout the Bandijuma district the murders of the men at the out-stations were particularly atrocions. In the Barri country a Fronticr was canght and taken to a big town called Bandasuma, on the Moia or Sulima River. His hands and 
feet were cut off, and a stone was tied round his neck, and he was flung into the river and drowned. In the Tunkia, Gowra, Koya, and Malema countries we lost men, who were all treacheronsly murdered. At the large town of Gegbima, in the Northern Tunkia, two men were asked into a friend's house, having been first persuaded to leave their arms behind them. While they were sitting conversing with their companions, one of whom was their own batman-a Mendi boythey were suddenly seized, their arms were pinioned behind them, and they were led, amidst the jeers of the crowd, out into the barri (court-house), where they were tied to posts and left all night. Next day, before a great crowd of people, their throats were ent in this Barri, their uniform burnt, and the little property they possessed was plundered. Their Mendi boy took a practical part in the betrayal and murder of his masters.

"Some native blood was seen thy streets to dye, A traitor only fell beneath the feud."

Besides these instanees, but a few of many hundred deeds of savagery, the men of the Frontier Force, who were scattered about the Protectorate in small detachments, suffered most severely from treachery at the hands of the insurgents. A large number were captured and tortured to death. In fact, whenever a Government official fell into the liands of the Mendis, all the devilish arts of torture in which they were versed were brought into play, and old scores were paid back with heary interest on those who, in their official capacity, had perhaps had unpleasant dealings previonsly with some of the people. It would take too long to describe a fourth, nay, even a tenth part of what took place between the natives and our men stationed about the conntry at the time of the outbreak. Much treacherons and horrible butchery was performed - many fights, sufierings, and almost desperate acts of valour on the part of our men when endeavouring to make their 

eseape or rescue their comrades. Some of these were weeks hiding in the bush, and during that time existed on roots and berries, arriving eventually at their headquarters in a famished and fearfully emaciated condition.

Enough! These melancholy stories must end. Many of these wretches were severely punished and suffered the extreme penalty of the law, which, to my mind, was far too good for them. There are still some lurking abont in the Protectorate with the guilt of blood upon their hands and upon their consciences. So far as their depraved nature will let them, they are suffering the agonies of a murderer's guilty mind, and their punishment will overtake them sooner or later, if not from the hands of the authorities, then from Nature's remarkable provision-the great law of compensation.

"For murder, though it have no tongue, will speak Vith most miraculous organ." 


\section{CHAPTER XIV}

THE RELIEF OF BANDAJUHA

"For this relief, much thanks."

Shakespeare.

$\mathrm{O}^{\mathrm{x}}$ N May 3, 1898, the Countess of Derby arrived at Bonthe, bringing 7 officers and 159 N.C.O.'s and men of the West India Regiment, with 12 headmen and 174 carriers, the whole under the command of Colonel G. G. Conningham, C.B., D.S.O. Their object was the relief of Bandajuma, the headquarters of the District which was at present invested by the insurgents, and from which no news had been received for several weeks. The Governor, when issuing his instructions to the officer in command, had advised the Jong River ronte to be followed. Here a base wonld be formed and an advance made to Mawfé, with a view to establishing communication thence with the beleaguered station.

On the 8th of May ten boats were obtained at Bonthe and loaded with stores, and on the following night, which happened to be a dark one, the adranced guard, consisting of 6 officers, 2 medical officers, and 120 N.C.O.'s and men and 140 carriers, under the command of Major C. B. Morgan, D.S.O., West India Regiment, started off at eight o'clock to occupy Mattru and there to form a base for pushing on up-country.

The force embarked in lighters, which were towed by the Bloncle's steam pinnace for three hours up the rirer. To 146 
assist the cutter in this work the crews of the boats pulled oars. At eleven o'clock the cutter cast off, and the force proceeded up-stream under oars only. The river at this part is fairly broad, the water black and dead-looking, and the bush bordering the banks as thick as thick could be.

After rowing hard until somewhere about 1.30 a.m., a large force of the enemy opened fire at Mapurgba, and from that time firing searcely ever ceased. The enemy must have had a considerable nmmber of guns and have been well supplied, moreover, with ammunition, for the fusilade directed at us from the banks was both hot and incessant. Our own expenditure of ammunition must at the same time have been prodigions, for it was quite dark and the enemy were well hitden, partly by the thick foliage and partly by the natural configuration of the river banks. Howerer, the want of light and the width of the stream together combined to prevent any serious loss in killed and womded on our side, thongh in some places the opposition was so determined that it was found necessary to land at all risks, in order to dissipate the attacking force and eapture their guns, which had been placed in commanding positions to rake us as we passed. Three successive times was this aecomplished; but it was found impracticable, owing to delay cansed by attacks on the part of the enemy and the necessity for landing parties, to reach Mattru that day, and the force encamped at Pepor, a small town on the Ronietta side of the Jong. This place was reached at 11.30 a.m., having been some eight and a half hours in the boats, and exposed to the enemy's fire most of that time. As already stated, our losses, considering the intensity of the firing, were marvellously light. The easualties up to this were a European sergeant-major and one natire soldier killed and twelve men wounded. The site of our eamp at Pepor was soon a very quagmire, the soft ground being speedily chumed into wet mud by the feet of the soldier's. Everybody's nerves were more or less strung up from having 
had to sit still so long exposed to fire, and even after our arrival at Pepor the enemy's attentions in this way continued. Next day the boats in charge of Major A. F. Dawkins, Nortlumberland Fusiliers, with thirty men of the West India Regiment, returned to Bonthe, and we heard afterwards that they had beeu fired upon both by guns and eannon for a great part of the distance.

On May 13th the remainder of the expedition under Colonel Cunningham's command, consisting of 6 officers, 118 N.C.O.'s and men, and 180 carriers, were conveyed across to York Island. At 11 a.m. we went off in a long string of boats towed by a couple of steam cutters from the Blonde, the four last being detailed for landing purposes. At Maturgba we were again fired upon, and I landed at Bowo, a little higher up, and captured and spiked a gun. Procceding, we again found it necessary to land at a place called Yali, where we were once more met by a heavy fire. Here a gun was captured and the town destroyed. Commander Hoskins was present with the expedition up the river, and covered the landing parties with his machine gun from the cutter. We did not arrive at Pepor until 8 a.m.

The mode of fighting in these expeditions was much the same as in the Timini country, probably the same tactics being adopted; although the Mendis lacked leaders, were comparatively poorly armed, and appearcd more in the open. The narrow winding patlis, hedged in by thick bush, were also much the same, and as the column advanced, the enemy's presence was not known until guns had been discharged at close quarters, which nearly always resulted in some of our men, usually the adranced guard, being lit.

We remained the whole of the following day at Pepor to prepare for the advance, and on the 15th of May we crossed the Jong Piver at 9 a.m., and the carriers and column swung out on the bush path in a long, straggling line. We had not been going many minutes when we were fired upon, which 

resulted in a Frontier being shot dead at a range of certainly not more than six yards. Proceeding on our way, we were constantly fired at, and the horns and war drums of the enemy could be heard in the forest beyond and around us. The advanced gnard, under Captain H. D. Russell, D.S.O., made rapid progress throngh the thick bush, and we passed many dead and dying of the enemy lying on the road. Owing to the carriers becoming worn out, we halted at Luawah, and camped for the night in the rain.

The next day, soon after dawn, we were on the mareh, the damp unhealthy mist, and the dripping branches bordering the narrow track, wetting us through and through. We were now in the Kemor country, and nearing its principal town, Bongeh. This was the place where Chief Berri lived before he was made a prisoner at Kambia. The hills here, known as the Bongeh Hills, are steep and trying to ascend. But the seenery, when the summit is reached, is very pretty, and the comntry in the immediate neighbourhood comparatively open. Here and there, dotted about these hills, can be seen small shelters or " devil hnts," built by the people to drive away the evil spirits. The Mendis are very suspicious of all hills, and believe that in every one lurks a spirit, which can work for good or evil upon them. Much eare and many sacrifices are made to appease these evil spirits and bring good into the country.

Before we reached Bongeh town we suddenly became painfully aware of a stockade barring on progress right across the road. It was hidden round a bend, and on the approach of the adranced gnard the enemy opened fire upon us, the slugs and potlegs singing and humming over onr heads, and whizzing down the path. The fire here was almost entirely frontal, and to avoid it, it was necessary to eronch down. This stockade was taken ly entting round it on both sides, as usual, and attacking it in front, which we did at the expense of two men of the West India Regiment wounded. It was 
trying work cramling throngh the bush, with difficulty seeing in what direction one was going. Behind the stockade there was a great deal of blood and two corpses, and the enemy must have snffered sererely here, believing, no doubt, that the white man's bullets would not penetrate their stronghold.

The heat had now become rery trying, and the steepmess of the ascent cansed several men and carriers to fall ont from exhaustion. We were soon all soaked to the skin by a downpour of rain, which greatly added to the discomfort of everybody. That night, after a very fatiguing and trying day, we camped at a small town called Gendama. Some of the men of the West India Regiment liad gone down with ferer, and so, althongh our casualties had not been heavy, our hammocks were rapidly filling. We were oft again next morning, passing throngh the same unhealthy forest bush. The road was barred in sereral places by great trees and other obstacles placed across the paths, which of course delayed the long column, and cansed the tail end to straggle. This had to be made np by doubling.

After a long march, during which we were fired upon several times, we arrived at Marfé. A few of the native lonses were standing among the rnins, and here we formed our camp. To our surprise no attempt was made to present our entry into this town, the scene so short a time ago of the terrible tragedy I have already endearoured to describe. The enemy were nevertheless all around us, and while visiting the ontskirts I saw sereral of them cantionsly spying at us from the distance, but they slipped away too anickly for me to get a shot at them.

All orer this part of the country leopards and other game abound, but, as is the ease all over this part of West Africa. the density of the bush makes it extremely difficult to get any sport. I have been ont for days, and have been able, by the aid of my slikiari, to track the spoor of swamp deer for long. distances throngh the bush, and have seen the pugs of 


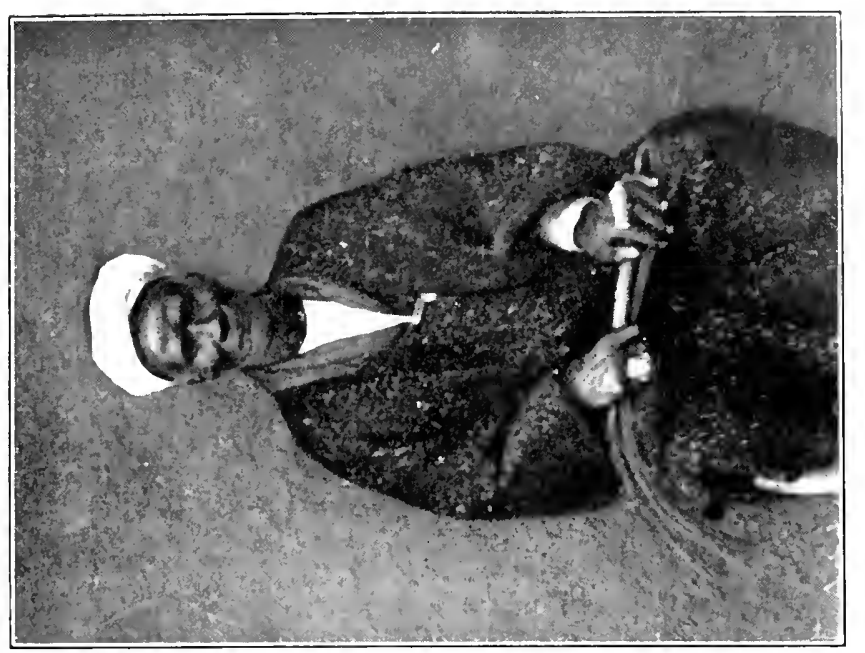

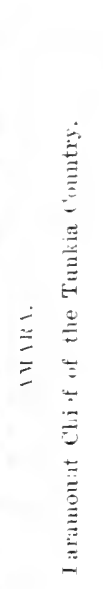

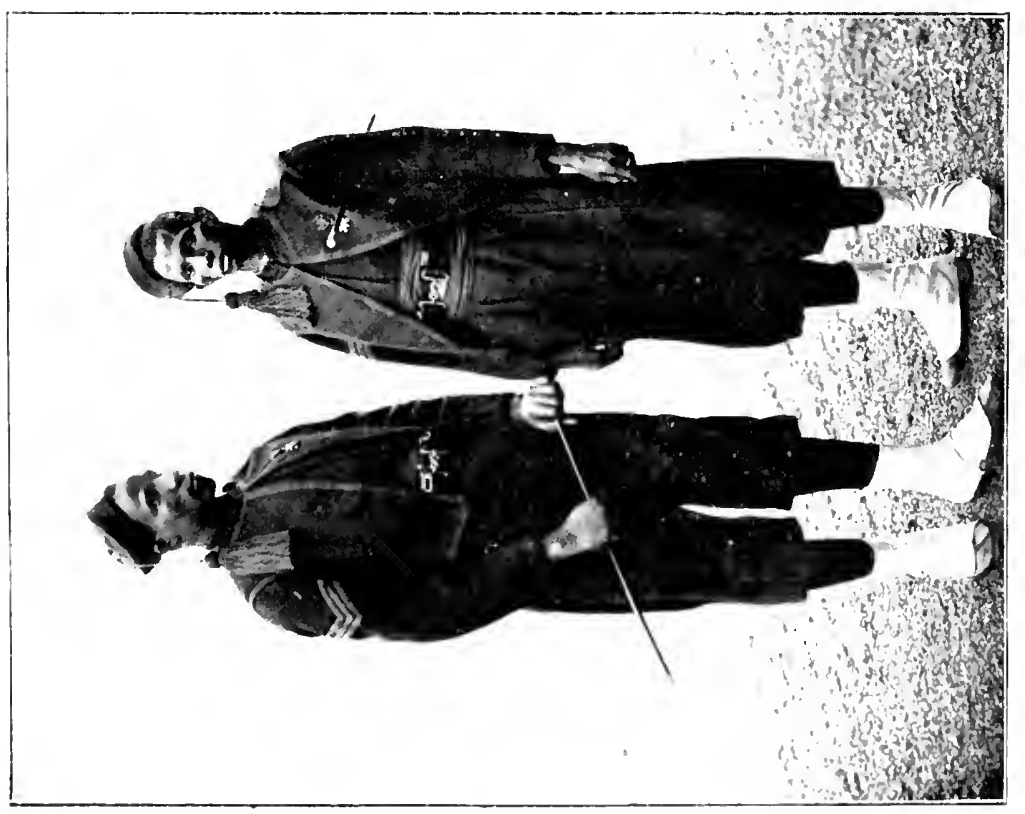

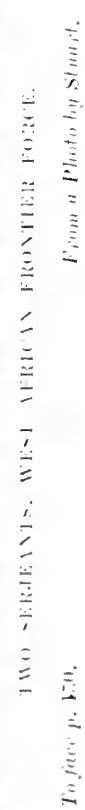



leopards and other beasts, showing that they were plentiful enough. Being disappointed after going out many times, and with the enervating effects of the climate continually working upon one, the mhappy conclusion is reached that West Africa is a poor comtry for shikiar. There are, of course, exceptions, and I have known men in lnck get most excellent shooting in this country.

The following morning, namely, the 18th of May, our camp was put into a state of defence, and recomnoitring parties were sent out with a view to dispersing any of the enemy collected in the neighbourhood. Nothing worth recording took place that day; but at 1 a.m. on the 19th the officer on duty was alarmed by a gm being fired off, which somded to be almost inside our eamp. 'This was the signal for the alarm, and everybody rushed to arms. I was sleeping in a hut, bordering on the ontskirts of the camp, when I was aroused by my servant rnshing in and shouting that the enemy were inside the defences. I remember bundling out, still half asleep, and in my haste was mable to find the matches and get a light. My revolver was close to my side, I knew, but in the hurry and confusion of the moment $I$ conld not in the pitchy darkness put my hand npon it. I now know well what Napoleon meant when he laid so much stress upon "two o'clock in the morning comrage." At that moment I felt that I would have given anything for that revolver and a light. There was a great deal of shonting going on, and it was found that we were attacked by a furce from Boompé, led by Chief Berewa, and estimated to be a thonsand strong. 'The Mendis were at their old game again, and had tried to creep into the town and stick us in our beds, bnt they lad found our sentries too smart for them. They attacked us several times, firing and charging, but could not withstand the steady volleys poured into them by our men at every point.

At daybreak a charge was made by West India soldiers and Frontiers, gallantly led by Major Morgan, D.S.O., who 
succeeded in clearing the enemy out, though he was unfortunately severely wounded in the head hefore the charge was completed. This drove the enemy off, and they left behind then over 130 dead. Many of our men were wounded by spears and swords in the fighting, some of which was hand to hand. At the same time we were attacked in front, the enemy, roughly estimated to be between two and three humdred, attacked us in rear, having first crossed the Boom Piver. After some fighting, they were charged, and driven into the river with severe loss. Forty dead bodies were comnted floating down the stream at the end of this engagement. Up to the present the Mendis, whenever they had met us, had suffered pretty severely, but they deserved a thousand times more punishment than being killed in action. Nothing would be too bad for the terrible deeds that were committed by these wretches, and when one looked at the wreckage all around, and saw the charred remains of the bodies, one felt capable of doing almost anything to revenge these dastardly deeds.

On the 20th of May a convoy arrived from the base. They had had difficulty in making their way, and were several times attacked, which resulted in the wonnding of three soldiers and several carriers. The road was, as usual, blocked by every possible obstacle. Felled trees lay across the path, while all the bridges were barricaded and broken. Most of the roads in this neighbourhood were stockaded and small parties used to go out, come into action, accomplish their object by the removal of these obstacles, and retum to camp before nightfall.

Arrangements were now being made to send a small force of picked men through to Bandijuma. There was some difficulty in crossing the Boom River, as there were no boats available, and so the carrier's, assisted by the men, were busily occupied cutting wood from the bush and constructing rafts. On the 21st a force of fifty-one men, consisting of the West 
India Regiment and Frontiers, under Captain N. E. Safford, and seventy carriers, left Mawfé at dawn, and after tro trips successfully crossed the Boom Picer on the rafts, and started for Bandajuma, some trrenty-eight miles away. The foree accomplished the journey in one day, arriving at Bandajuma before dark, which was most excellent work. There they found the place closely iuvested and quite cut off. The station had been attacked by large numbers of the enemy, who had been driven off with heary loss each time. The old paramount chief of the Sowra country, Momokiki, and who resided in the native town of Bandajuma close to the barracks, had been obliged to be loyal owing to his proximity to the Govermment. He had assisted us to hold the place with at least two thousand of his people, and his brother Momo-jah, a powerful chief, who held sway in the Lower Sowra or Upper Kittam country, and who resided in a town called Pujuhnun, which was some eighteen miles away, also assisted us, and rendered a great deal of valuable service later on.

The old Chief Momokiki was a man of between eighty and ninety years of age. In spite of his year's he was fairly active, and possessed a tall and striking figure with a pleasant face. He was not a pure Mendi, his father, as I have said before, being a Fullah man who eame into Mendiland when quite young and married his mother, who was a pure bred Mendi woman. At the commencement of the rising, and when first Bandajuma was attacked, the old chief hesitated as to which side he would join. He was certainly in an awkward position. If he threw in his lot with his comtrymen, and the British held their own, he would be canght and imprisoned, perhaps langed. On the other hand, in the event of the eneny succeeding in taking the place, he wonld have been most certainly killed. On the first victory of the British he joined hand and glove with us, and his brother, Momo-jah, one of the eleverest and most emming men in the whole comtry, joined with him. We conseguently liad 
sereral thousand natives assisting us; but had it been the other was, I think there is little doubt that the station would have fallen.

Chief Momo-jah was a most interesting personage. Of short stature, I think he possessed a pair of the most cunning eyes I have ever seen. He was considered a great warrior in the country, and had been mixed up for years in the old tribal wars, and with the eatehing of slaves. He had probably seen as much bloodshed, and indirectly assisted in the slaying of as many people, as any man in the country, which is saying a good deal. I came to know this chief rery intimately afterwards, and he has told me most extraordinary yarns of his former doings. He was a most able man, and eonsequently, being an uneivilised native-langerous. He had, howerer, thrown in his lot with the Gorernment, foreseeing before most of his fellow subjects that there was no other course open, and has certainly rendered us much serrice in the country from time to time.

The force under Captain Safford, West India Regiment, retumed to Mawfé on the 25th, and two days previously another convoy arriced from the base, haring been as usual attacked on the road. Prior to the retmrn of Captain Safford, his men, accompanied by Frontiers, and 300 leries, marched to attack the tom of Largo in the Jiama country, some nine miles from Bandajuma. The object of this attack was to break up a force of the enemy who were reported by our spies to be assembling there preparatory to making another attempt on the station.

This town of Largo has one of the most interesting histories in the Prutectorate. For years it was the great slare market for this part of the country; and was consequently the scene of a number of horrors and atrocities. It is a rost picturesque town, closely surrounded by unusually gigantic bush which abounds with monkeys. The Paramount Chief, Makaia, whose name was a terror to the people for 
miles aromnd, was probably the biggest mffian and slave holder in the comntry. He would organise periodical raids, one of these resulting in the capture of six hundred women and children. Things got so bad at last in the Jiama comtry, that an expedition was organised in 1889 against Makaia; and the foree, accompanied by the Governor, Sir James S. Hay, arriving at Largo in the early dawn, surprised and attacked the town, destroying it and setting free a thousand slaves. Owing to the success of this last expedition, Chief Makaia was taken prisoner, and sent into Sierra Leone, where he died in gaol. His snceessor, who ealls himself Shaffi, and who in his time had been a great slave-dealer also, has reconciled himself to doing without them, and now, as he says, "sits down for the British Government." I have found him an easy man to deal with, thongh he is weak with his people. He has often told me the most exeiting stories of the old slave days, and we are good friends. He now enjoys the peace which the Govemment has brought into the country.

It was thought necessary to establish a post halfway between Mawfé and Bandajuma. This would be at Jini in the Upper Big Boom country; where, on my first mareh up-country, we reeeived that scare about the smallpox. The tornado season was now approaching, and rain fell daily; and in another three weeks the "rains" would be in full swing. On the 26th I left Mawfé with a foree of Frontiers and West India soldiers, and several labourers for Jimi, there to establish a post. After the first two hours' marching heary rain came on and we were soon soaked to the skin. This delayed our progress considerably, and after being on the tramp for eight hours, we arrived at Jimi only to find the place burnt to the gromend. Not a stick was standing, and we hat no tents, while the rain was coming down in sheets. The men were standing about in shivering gromps, and everything looked most depressing and miserable. At last the 
labourers ent some palm leaves and sticks from the bush, and after about an hour sneceeded in putting up a little leaf shelter, three feet wile and fonr feet high. The natives are so clever at this that in spite of the severity of the rain not a drop came throngh, and althongh the gromd beneath us was wet and thick with mud, I crept, shivering, beneath my shelter, and in spite of all slept the sleep of the weary the whole night throngh.

The next morning, before daylight, I started on the return march to Mawfé, liaving left a post at Jimi. This march was unerentful, with the exception of one umspirited attack by the enemy, who were easily driven off. We were several times soaked to the skin by the rain, but after a time one gets aceustomed to these little inconveniences, even to the drying of one's clothes on one's back, which has often happened to me, but from which I never felt any ill effeets, due, donbtless, to being on the move while the drying process was going on.

While our column was going up-country, Major Dawkins, in command of the base, had been clearing the neighbourhood of the insurgents, and on the 27th of May he attacked and destroyed the large town of Tilinn, in the Small Boom country, and captured a camnon there. At this place many atrocities had been committed, and it was considered to be a big fetish town, so the destruction of the place had a considerable effect upon the people.

On May the 31st the officer commanding the expedition marched to Bandajuma without opposition and found things there in a little more settled condition. The return journey to Mawfé was made on the 2nd of June, a halt being made lalfway at Jimi. This town had been attacked at 3 a.m. that morning by a number of the Boompé people, and others, who had crept close up to the sentries withont being discovered. They were driven off with loss by Captain H. E. Hutchinson, West India Regiment, who was in command of the post. 
Although Bandajuma, the headquarters of the district, was now free from further attacks, the immediate neighbourhood was in a very disturbed and dangerous state. The place was full of armed and concealed war-boys, and it would take some time before the pacification of the country was achieved and the murderers canght and bronght to justice.

Meanwhile, numerous small local expeditions were going out daily, and the enemy were attacked and their towns destroyed in the immediate neighbourhood.

This station was in a most perilous position at the commencenent of the rising. There were quite fifty men stationed in small detachments about the District, and the majority of these were treacherously canght and murdered, while others had hairbreadth escapes, and lived on roots for days together, hiding in the bush. At that time also the Commissioner was away in the Dama country-some three days' march, with forty Frontiers, on Honse Tax dnty. This foree, shortly before the rising, was quartered at the prineipal town of the comutry, ealled Pendabu, where the Paramount Chief Jaberti resided. The men, never suspecting the coming trouble, were as usual scattered about the town in different luts. Everything was previonsly arranged by the natives for the massacre of the force, and the ehief had agreed to murder them all that night, when a question as to the sharing of the plunder eropped up. The chief not being satisfied with the proposals made by the Krubas and others in authority, postponed action for another day. The following morning the Commissioner, having received intimation from Bandajuma of the impending trouble, started off, choosing a little frequented road. Marching night and day he snceceded in reaching the station in the early norning about two hours before the attack was made. This was a fine performance. Had he passed by the usual road he would liave been attacked and ambushed by great numbers who were watching for lim. He would also lave found his passage 
across the Moia river, one of the largest in the Protectorate, barred. Also, had the chief been satisfied with his reward for the treacherous extermination of this party, they would most certainly have been numdered the night before they left Dama. Unfortunately, during this march the boy bugler, who was unable through fatigue to keep up with the party, was compelled to fall out, and he remained behind and was canght and murdered by the men of Chief Amara of Gorahum, the Paramount Chief of the Tunkia country. This chief was concerned in several murders, and took an active part in the rising, but unfortunately there was not sufficient evidence forthcoming by which he could be convicted, and he still rules his country.

The attacks on Bandajuma were vigoronsly made by great numbers of the insurgents. It was, however, in a good position for defence, standing as it did on a rise, with a large space of cleared ground all round. The enemy suffered severely, having to come a good deal into the open, and their sknlls and bones were found lying about in the bush for montlis after. Had they made their first attack two hours earlier, before the arrival of the party from Dama, there is little doubt that the station would have been taken, as the officer then in command, Captain T. B. Eames, had only a force of about sixteen men, and he was at the time suffering from fever. For several weeks this station was closcly invested and quite cut off from the ontside world; there were few provisions in the place, and all were on "half rations," a very unpleasant and serious matter in a climate such as this is.

One of the great strongholds in this part of the country, and in which the native people had unbounded faith, was Boompé town, in the country of the same name, a distance of about seventeen miles from Mawfé. The people here had from time immemorial been the great warriors in the southern portion of the Protectorate, and were always successful in the many wars and slave-raiding expeditions which they periodically carried out. 
The town of Boompé was, moreover, a powerful fetish place, situated on the Tarbe river, which was held to be sacred by the people. Close to this town and on one of the banks of the river is a fetish grove, which is still existing and which the people assert has never to this day been visited by any white man. They are very much averse to any strangers going there; and although I endeavoured to visit the place in 1902, I saw it was distasteful to the people and so gave up the attempt. The Tarbe river at this point has most lovely scenery, and is as usual slut in by almost impenetrable tropical foliage. Scattered along its banks, and within a milc of the town, both up and down stream can be seen the Jujn fetish of the people, in all its variety. Their queer customs, all of which tend towards one thing, namely, the driving away of the evil spirits and encouraging of the good, are absorbingly interesting and well worthy of careful study by all those who take an interest in West Africa and its peoples.

In consequence of Boompé having been impregnable in the past, it was supposed by the inhabitants, for miles around, to be in possession of very strong and powerful "medicine," especially made and consecrated by the Morri magicians and proof against the attacks of the white men. $U_{p}$ to the present, this town had not been attacked by any British column, and although a number of the people had been killed in the various attacks made upon us, the country round was of opinion that we should always be mable to take the place owing to the amount of fetish by which it was surrounded. Until this place was taken and destroyed, therefore, the great number of the chiefs in this part of the country would hang back and delay bringing in their submission to the Government.

Consequently, on the 11th of June, a force of the West India Reginent, commanded by Captain Riussell, D.S.O., left Mawfé for Boompé, which they attacked at early dawn the following morning. The town was very heavily stockaded by 
two lines of fences, and a most determined and plucky resistance was made by the eneny, who held on to their position until the last and until eighty dead bodies lay behind the stockades. Inside the town all kinds of "medicine" and fetish charms were discovered. The stockades were destroyed and the town fired, those of the enemy who were not dead or wounded fleeing by crossing the Tarbe River, and hiding in the surrounding bush. Considering the determined character of the resistance made by these people, our casualties were very small; Captain Russell and three men being severely wounded, and three men slightly wounded.

When the smoke of the buming town was seen by the eagerly watching inluabitants for miles around, and they knew by this sign that their stronghold had been taken, the people in this part of the country began to see that it was impossible to figlnt the white man, and cast about as to the best means of surrendering to the forces of the Great White Queen.

While the relief of Bandajuma was taking place, Panguma, the headquarters of the Panguma District, had been steadily attacked by large numbers of the enemy, who had completely surrounded the place and made desperate efforts to capture it. It was consequently quite cut off from the ontside world, and much apprehension was felt in Sierra Leone as to the fate of its gallant defenders. Orders had been received from the Governor that Panguma was to be relieved at all cost, if possible, by a force from Bandajuma, who conld reach it by good marching in four days. Accordingly, on the 9th of Jume, a force consisting of forty-five Frontiers, and a number of Fricndlies, under Captain Eames, left Bandajuma with that object. Resistance was not met with until the second day, when a large number of the enemy secreted in the bush opened fire on the party. Pushing on, a town called Doija was reached, when another attack was made which resulted in three of our men and one Friendly being killed, and several Frontiers wounded. Difficulty now arose by the Friendlies and 
carriers refusing to cross the Panguma border. Every effort and threat was made to induce them to do so, but mavailingly; and the party having gone thirty miles, and finding they conld not proceed without their loads, which consisted of ammunition and provisions for the beleaguered garrison, were forced to retire, and returned to Bandajunıa on the 13th. 


\section{CHAPTER XV \\ OPENING UP THE KITTAM \\ "We have met the enemy and they are ours."}

$\mathrm{T}$ became necessary that communication should be obtained
by water with Sherbro, and it was decided that the Pirer Kittam would be the most conrenient route. That part of the country had as yet receired no punishment, and was still in open revolt. The inhabitants had committed a number of fiendish atrocities, as well as destroying and plundering every factory in the place. The Kittam was blocked, and no boats except the war canoes of the enemy were permitted to pass up and down it. Accordingly, on June 12th, I left Bandajuma at dawn with a force consisting of one corporal and thirty Frontiers en route for Pajuhun in the Sowra country, eighteen miles away, whence I was to open up the river to Sherbro, destroy the enemy's towns, and inflict as much loss upon them as possible. At Pujuhm I was to be met by the Chief Momo-jah and a force of about fuur hundred of his war-boys whom he had placed at my disposal. We reached Pujuhum at 4 p.m., and found the town heavily stockaded and crammed with people. They were either seeking refuge under the protection of the chief, or assisting him to defend his town against the insurgents, who had several times attacked him because he had thrown in his lot with the Government. 
Several of the chief's war-boys who were to accompany me had already arrived in the town, and a queer looking lot of ruffians they appeared. Some of them had been armed by us with Snider rifles, and given a quantity of ammunition, while many of them had their own guns, swords, and every conceivable kind of weapon in the way of sticks, bludgeons, knives, and clubs.

That night the chief treated me to one of the best wardances I have ever seen in this country. A huge ring was formed by the spectators, and at the beating of the tom-toms, or sang-bois, as they called them, each warrior would step into the centre and begin his performance. It had been a time of victory for them, and further victories were ahead. The white man had come to join with them, and to-night they would celebrate the fact.

As a rule, when about to perform the war-dance, the warriors are stripped naked with the exception of a cloth about the loins; and magnificent specimens of the genus homo they appeared as their muscular limbs and torsos caught the light of the flickering torches. For head covering they wore a country-made cap or gaudy handkerchief, and the arms, knees, and ankles of every dancer were hung with bunches of fetish charms. Each man was armed with a heavy-bladed sword which, when they cannot afford a gun, is still their favourite weapon in war.

On first entering the ring, each warrior advinces to the centre where he stands like an ebony statne gazing, sword in hand, at the audience crowding round. Meanwhile the beating of drums and throbbing of tom-toms continues ever to grow louder. The performer now holds out his blade at arm's length, and with the point describes great circles with a sweep and swiftness that the eye can scarcely folluw. Now his weapon is clearing the air in lightning-flashes above his head, now rippling in fiery arches round his body, while the "duba-dub" of drum and tom-tom is reduubled and the onlookers 
applaud with a deep-throated roar. The dancer has by this time worked himself up into a perfect frenzy and his whirling blade is become a very comet-track of steely sparks in his fast sweeping hand. On he dances, twirling and gyrating around the circle of "kept" ground, the andience testifying their appreciation of the performance by that slow deep roar of sustained applause. Then, when the excitement is at its height, and his furious dance has reached a climax, the man suddenly bounds across to where his chief, or the personage in whose honour the tamasha is given is standing, and, driving his reapon point foremost into the ground, crouches at the great man's feet. On this occasion I was the recipient of the honour, and the etiquette of the eeremony demanded that I should touch the man's shoulder with my right hand to signify my acceptance of his war-like serrices as well as my appreciation of his terpsichorean efforts.

And so the dance went on. To sooner had one man finished his "turn" than his place was taken by another; the people crowding round the ring becoming more and more excited as the dance proceeded, whilst the quick-throbbing tom-toms added their quota to the general din. The scene that night, all bathed in pale moonlight, was brilliant and bizarre in the extreme. In the foreground the cleared ring of ground, in which the eoal black warriors danced and postured; hemming them in, a shouting, lowling mob of fantasticallygarbed natives; behind, again, the dim ontlines of the village huts and, for background to the reird picture, the ink-black of the dense foliage that girt us in before, behind, on every side. And the thought struck me as I stood there, unarmed and quite alone, and glanced romd at the villanous visages that confronted me in tier on tier, how rery easily treachery could lave been displayed upon the white man standing practically at their mercy. Howerer, nothing untoward happener, and I retired at the conclusion of the performance after an expression of thanks to the chief for 
the display, and the distribution of small presents to each of the participants.

The next morning we were early ready for a start. First, the chief drew up lis horde of truculent-looking war-boys in two lines for my inspection and also introduced me to the "captains" of the different bands. At the head of the party was the chief's own son, who accompanied me throughout the march, and who, unfortunately, lost his life in the fighting that ensued.

My initial object was to march down to a place called Barmah, embark there upon the Kittam River, and so open up a road to Sherbro by water. Barmah was distant only some three hours from that town direct; but as the whole neighbourhood was alive with the enemy, it was decided that a more circuitons route had better be adopted. Accordingly, fifty of the Friendlies and five Frontiers were detailed as scouts and ordered to make a wide sweep of the country, passing through Sowara, Tabor, Petima, Kortuwaun, Gumasun and other towns. Momo-jah's warriors were quite at home at this sort of work, and rendered very valuable assistance, although I found it difficult to keep them in hand and prevent them wandering off on private expeditions of their own in seareh of loot. Whenever wo came into the vicinity of the enemy, the native levies would incontinently disappear, but invariably on their return it would be found that they had done great slanghter, and some of them would bring back a hand, a foot, or some other portion of a luman being as a proof of their prowess.

Continuing on our way we came at length to Barmah, where we found several of the loyal headmen waiting to receive us. I had decided to dispense now with the services of most of the native warriors, and retaining only about a hundred, I embarked them and my men in four large barges, all of which lad been previously barricaded, and to the singing and drumming of the war-boys we hmbered off down-stream.

Of all the waters in the Protectorate there are, I should say, 
none that is more infested with mosquitoes than certain parts of the Kittam Rirer, and I suffered torment unspeakable from these diminutive foes. The river banks in this part are not lined to the water's edge with impenetrable forest, but border upon pleasant open grass fields. Game is abundant all over the locality, and water-deer, pig, and hippopotami abound. The river itself, for the whole distance, presents an appearance that is wearisome in its monotony. Its waters are inkyblack, the banks and inlets thickly fringed with reeds, amid which plenty of crocodiles lurk and hide. All this low-lying swampy part of the country is very densely populated, and we passed numbers of villages on either bank. "Swiftly ran the current, swollen high ly months of rain." We were, in fact, in the heart of the rainy season. The barges were, therefore, taken down at a good pace. As it was my object to reach Sherbro as quickly as possible, I did not intend to attack any of the towns on my journey down, reserving that business for the return trip. A tour in boats like these of ours would be a pleasant enongh experience in fine weather. But when you are in the middle of the rains, and are compelled to sit for hours in close and cramped proximity to a crowd of naked and perspiring blacks, the thing is not a picnic party. Orer my boat, which was supposed to be the best of the lot, there was, to be sure, a rough sort of amning spread, which was intended to keep the rain out. It succeeded indifferently well in doing this. Nevertheless, owing to the superhuman efforts of our war-boys, who were spurred and encouraged to ply their paddles by a fearful and deafening row from the tom-tom men and other musicians of the party, we made good and rapid progress.

About 2 a.m. on the following morning the man in the fore part of the boat drew my attention to what looked like several small, black logs creeping across our bows about 200 yards ahead. These, I was told, were the enemy's war-canoes. We continned, nevertheless, to pursue our way and now, as we looked ahead, another canoe shot out, then another, and yet 


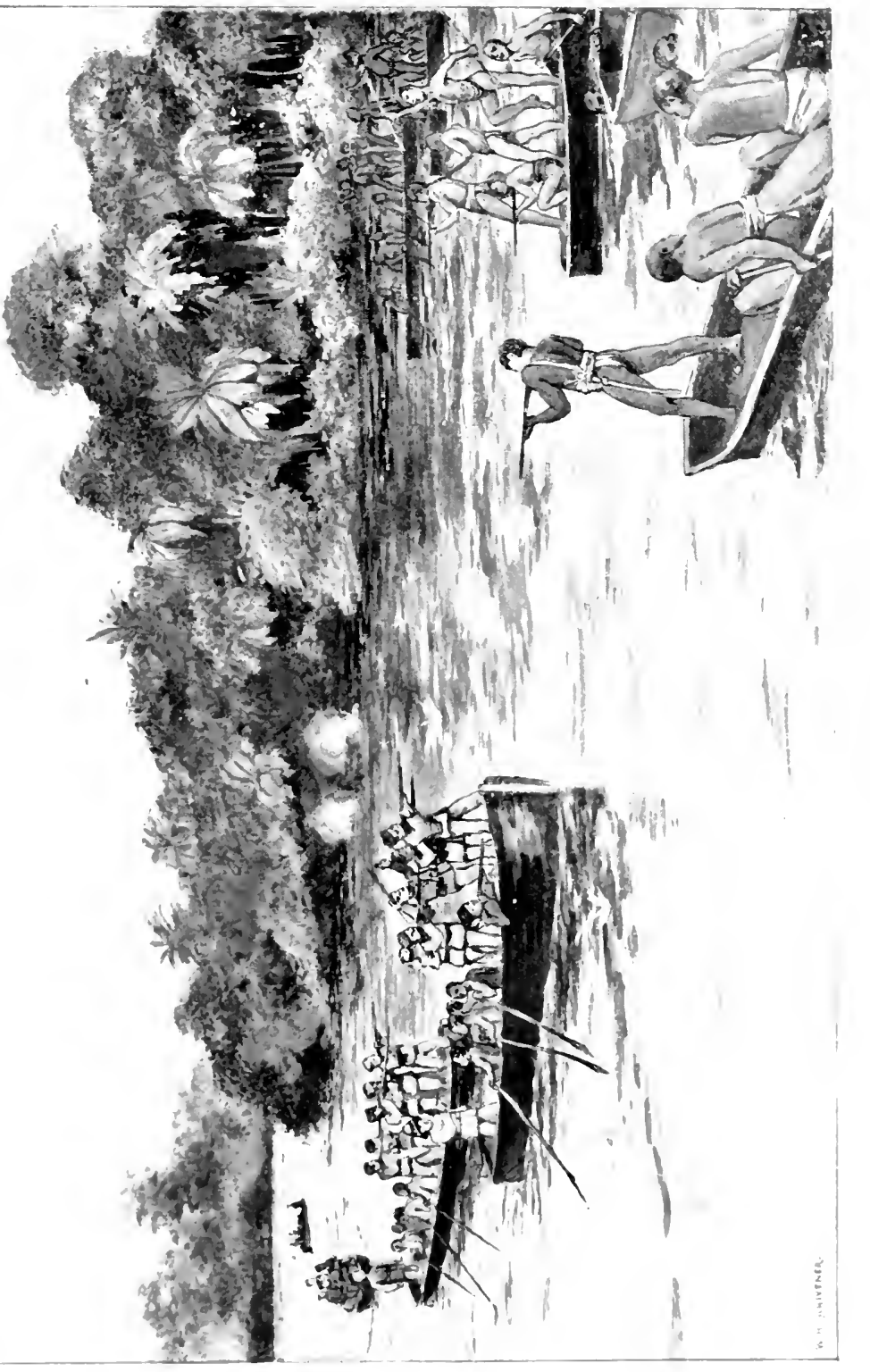



another, until the river was dotted with upwards of fifty of these eraft, some large, some small, but all of them filled with men. It was now high time to take precantionary measures. Rowing therefore ceased, and as we drifted down-stream every man got his rifle ready and looked forward to the fight which he knew was coming. That they had seen us all doubt was quickly at an end; for rery soon a voice called out in Mendi to know who we were and whither we were going. The corporal in my boat, who happened to understand the language, replied promptly that we were Sierra Leone people who were running away from the war and on our way to Sherbro. Instantly there arose a great hubbub amongst the canoes, and as the light improved, we could see that preparations were being made to attack us. Every man in our boats was now crouching down behind his little wooden screen with rifle loaded and the muzzle pointed ontward from the boats. The ehief's son, who was in my boat, at this point almost spoilt our game by his orerexcitement, and it was with great difficulty I could restrain him from loosing off his gun haphazard into the midst of the canoes.

My plan was to allow them to get as near to us as possible and then to open fire upon them at point-blank range, when they would find, instead of hunted traders and women fleeing for their lives, they had to deal with men of sterner stuff.

Meanwhile the canoes began to draw nearer to us, and gradually formed a sort of semi-eircle round our bows, the intention being to elose in upon us and put us all to death instanter. When they were sufficiently near I gave the word "Fire!" and instantly sharp tongues of flame spirted from the rifles, and the silence of those lonely river reaches was torn to tatters by the din of battle. Our Friendlies joined in with their long "Dane" guns and added to the noise. At such close quarters the effect of our fusillade can hetter be imagined than described. Although in the bad light aceurate aiming was a matter of impossibility, we were so near them 
that a great number must have been hit. Our fire was immediately returned with slugs, which hit several of our men. But in their haste to get away some of the canoes had capsized, while the occupants of others plunged into the river to escape the hail of lead that rained all round; and the water was dotted for many yards with bobbing heads. We then took to our oars and resumed our course.

By this time the whole neighbourhood was roused, and it seemed that we were not to be allowed to get away without a scrimmage after all. No sooner had the swimming Krims and Mendis reached the shore than the news was flashed from place to place with the incredible swiftness with which tidings are known to travel in this country, and we were repeatedly fired on from both banks during the whole of the succeeding night. Thanks, however, to our barricaded boats and other precantions, very little damage was done. And so we went on, many a time wet through, tormented by mosquitoes and fired upon incessantly by the insurgents. Howerer, the river was now becoming broader, and as it did so our difficulties decreased. At last, on the morning of the third day we arrived at Bonthe, where we remained two days, and where $I$ gave the Friendlies a good feed and presents, and permission to go ont and enjoy themselves in the neighbouring fakais until I was ready to return; the chief's son courteously coming in to report to me daily how the camp was getting on.

Returning, we had sterner work on hand, my intention being to destroy every town and village of the enemy on either bank. The blockade of the river had to be raised at any cost, and the most efficacious way to do this was to raze the strongholds of the enemy and destroy his food supplies whenever and wherever possible.

I see by my diary that we left Bonthe at twelve o'clock that day, in time to catch the tide. With the usual accompaniment of noise and shouting on the part of the Friendlies we bade goodbye to the crowd which had gathered to see us off. 
It is always a dreadfully tedious matter embarking in these boats with natives. The babel of voices is terrific. Everybody talks at once, and all hands crowd into the boat and stand up doing nothing but shouting and yelling at each other. You may be sure that if any are left standing on the bank they will do their best to jump in, notwithstanding that the capsizing of the canoe is a dead certainty. You shout until you are hoarse, and the whole business would be most exasperating did it not have such a funny side.

Our progress now was painfully slow owing to the strong tide that made against us. We passed scveral small towns and villages on our way which were fired, the people in this part making no resistance. Our war-boys invariably bronght back quantities of loot of every kind : fowls and ducks of every degree of seragginess packed in little native-made baskets; tied and struggling goats and sheep that bleated piteously at their captors; while now and then a fine fat porker would be added to the common stock, squealing and straining in his futile efforts to get his tied legs free. Besides these, great baskets of rice, paupaus, bananas, and in fact every possible kind and description of portable matter were put on board, until the boats resembled nothing so much as trading scows on their way to market. Considerable time on this journey was taken up in embarking and disembarking upon these sinall forays.

We passed Bap at one o'clock in the morning. It had been my intention to destroy this town, but, owing to the darkness, we had gone quite a mile beyond before it was discovered that we had missed it, and I scarcely thought it worth while to return. For the reason that it thus eseaped, this town has since been locally regarded as a great "medieine" village, and the native, as usual, confusing eause with effect, considers that it owes its immunity from destruction to that fact. I ruote this as but furnishing another instance of the strong hold that "medicine" has upon the native mind. 
The burning of a place called Kattin resulted in a fight. While we were engaged in firing the apparently empty town, the inhabitants erept up through the bush and opened fire upon us; but the Friendlies replied, doing great execution amongst them. Continuing on our way, we reached Toon, noted for its lunge and renomous mosquitoes. Close to this place the Boom River joins the Kittam, and here the name is changed to the Boom-Kittam. Proceeding, we came to Malipumpa in the Quarko country. This place we reached in the darkness, and in the stillness of the tropical night our barges grounded, and the Frontiers, having previously fixed bayonets and fired a volley into the town, charged it, accompanied by the yelling Friendlies, when the night was soon aglow with the blaze of the burning village.

Our barges had by this time become so full of loot that we were scarcely able to make any progress whatever, and much to the chagrin of the Friendlies, I insisted upon their leaving some of the livestock behind, else, native-like, they would assuredly have filled up every boat until it sank.

At Teh we again had a tremendous battle with the mosquitoes, and nobody except those wlo have gone through it know what a misery it is to be robbed of one's sleep by these pests after a hard day's work in the broiling sun.

It had taken us four days in our clumsy barges to come thus far, and when we reached Mopalma, we were some ninety miles from our starting-point, having fired and cleared out nearly every town cn route.

Eventually, however, we arrived at Barmah, where a large concourse of people, including the chief Momo-jah, had assembled to meet us. That night another war-dance was held; but on this occasion its magnificence was somewhat marred by the fact that the chief's son, who was with me, had been severely wounded, and was in fact in extrcmis even then. He died shortly afterwards. We had had some few casualties also among our Friendly allies, who had done most excellent 
work in spite of their propensity for loot. Yet, beyond its success from the punitive point of view, this journey was, upon the whole, the most wretched that I had ever undertaken. I felt low from the incessant mosquito bites, stiff in every limb, and indeed had almost lost the power to walk from so close and long confinement. Still, our miseries had not been endured in vain. For there was at least "something accomplished, something done, to earn a night's repose"-to which, indeed, our party had long been strangers. 


\section{CHAPTEF XVI}

OPERATIONS IN THE RONIETTA DISTRICT

"Dulce et decorum est pro patrix mori."

A sill be seen by the map, the Ronietta District lies to the Pbar-Mendis, Sherbros, Yonnis, and Timinis. This was one of the districts in which the House Tax was to cone into force in January, 1895. The inhabitants of this part of the Protectorate had nearly all joined in with the others and taken the oath for the destruction of the white man. The chiefs here wielded considerable power, and were of no small importance locally. Early in January they held a meeting, (one of many) at a place called Masimera, and among other matters decided not to attempt to pay the House Tax. This meeting was largely attended, the principal chiefs present being Bai Sherbro of Yonni, Bai Kru of Mabang, Bai Simera of Masimera, and a sub-chief named Kapru Massim, who represented a powerful man named Bai Yosso, of Mayosso. Other meetings took place in the Mabanta and Bagru countries, and there was unrest throughout the whole district. The Kwia country, one of the largest in Ronietta was also unsettled, its two most important chiefs, Pa Nembona and Bai Kompa, doing all they could to get the people to postpone the tax payment as long as possible until the time had arrived for them to strike. 
There was consequently considerable difficulty in the collection of the House Tax in the Kwia country at this time. The paramount chief, named Bai Kompa, a man of importance in the country, and of considerable strength of character, and who was stirring up others to drive us from the country, practically refused to pay the tax. An attempt was made to arrest this chief on the 19th of February, but without success. On the 27th of February, the Acting Commissioner of the Ronietta District, the late Captain S. Noore, having been informed that Bai Kompa had fortified himself at Maketti, an island on a tributary of the Rokelle River, left Kwalu, the headquarters of the district, for the Kwia country witl the object of effecting the capture of this chief. He had with him one native officer and forty Frontiers. On the 3rd instant the foree was joined by Major E. D. H. Fairtlough, C.M.G., D.S.O., the present Commissioner of the Ronietta District, and proceeded to Makompa, passing through Robia and Rokonta. At Robia the rear-guard was fired upon, and the party were followed by war-boys right along to Rokonta, where during a halt efforts were made by them to rush the sentries. The party camped for the night at Makompa. The next day, when they were embarking in canoes for Maketti, at which place the chicf was supposed to be in hiding, the baggage, which had been left behind in Makompa, was attacked by a very large force of war-boys. This necessitated the return of the force to that place to relieve the baggage guard, which was done, the insurgents being driven off' with loss. The linnted chief was reported to have removed to Mangeh, a rillage near Clines town, and thither the party marehed, meeting with considerable resistance on the way. The ehief was not, of course, found there, and now he was reported to have returned to Miketti. The party, therefore, went back to that place by another ronte, meeting with resistance for the greater part of the journey.

On arriving at Maketti, which they found deserted, the 
party were attacked from the bush, and in the fight which followed a sub-chief named $\mathrm{Pa}$ Weal, who was the leader of this attack, was taken prisoner. The force then returned to Robia, where it camped for the night, and was attacked at 5.30 p.m. The attack was repulsed with loss. At midnight they were again attacked on three sides; but after three quarters of an hour's fighting the insurgents were driven off. They suffered severely in this action, in spite of the darkness. On the 7th the towns of Makompa and Robia were burnt, and on the 11th of March the party returned to Kwalu. The non-success in apprehending Bai Kompa gave considerable encouragement to him, his sub-chiefs, and the people. Two sub-chiefs, named Almami Senna Bunda and Suri-Kamara, obtained help from the Karene District, blockaded the Rokelle river, and defied the Govermment, besides threatening the people in the country with death if they paid any tax, and did not join the war party.

Accordingly, on the 5th of April, fifty Frontiers, under the command of Major Fairtlough, proceeded to Ronietta in order to interview a friendly chief called Fula Mausa, of Yonni. This man endeavoured to induce Bai Kompa to surrender himself to the Government. He accompanied the force to Mafuluma, where the natives were holding a large war-dance. The party was attacked while crossing a small stream close to the town, but the enemy were driven off, leaving six killed, and some wounded behind them. At 3.30 a.m. the insurgents made an attempt to retake the town, but were again driven off with a loss of seven killed. One of Fula Mausa's men, who had been assisting us, was killed, and another wounded, in this action. The towns of Mafuluma and Maseracouli were destroyed, and the party pushed on to Maiumera, meeting with opposition on the road at a small village called Batipo. At Mainmera we were attacked four times during the afternoon and at abont 9 p.m. a night attack was made. The Friendlies belonging to Chief Fula Mausa rendered much 
service by following the enemy into the bush, where they invariably managed to kill several of them. They captured the chief Kruba (warrior), named Paumri, during this attack. Opposition was now met with everywhere our force went. Hot fighting took place at Fonde and Rofntn. At the latter place two Friendlies were killed. At Foroduju, a kind of mud fort had been erected and loopholed, and thither the party went after being ambushed near Romabing. More fighting took place at Robia, which was burnt, and the insurgents were also driven out of Foroduju with a loss of five killed and several wounded. This town was subseqnently attacked by a warrior named Suri Kamora, who, however, was repulsed.

On the 10th, ten men in charge of a sergeant and accompanied by a number of Friendlies were sent to Majaksun, a town situated about five miles south of the Rokelle River; while another party went by river to Masengbi with the object of encountering the enemy if driven back by the first party. Strong opposition was met with by the first party, which was ambushed close to Majaksun; but the enemy were repulsed and had to retire on Masengbi. Here they were met by the second party, and being caught between tro fires suffered severe loss. Shortly after this the party returned to headquarters, arriving at Kwalu on the 23rd of April.

On May 2, 1898, Kwalu was attacked by the insurgents, estimated at two thousand strong, and led by the War-chicf Yombasu. Owing to runours in the Panguma District the officer in charge at Kwalu was asked for reinforcements. Thirty mon were therefore sent to Panguma, which considerably weakened the garrison at the former station. Although the insurgents had been driven off after their first attack on Kwalu, they remained in the immediate vicinity until the 7th of May. On that monning another large force, estimated at five thousand strong, and accompanied by a host of shouting musicians and banging tom-toms, again attacked the station, and after sharp fighting was at length repulsed 
with heavy loss. Several of the important Krnbas in the country had led this attack. These included Yombasu of Taiama, Lokai Boom of Maro, and Kassi of Bap-all men of power and importance. While this attack was being made, the war-boys shouted at the defenders in Mendi, "Your time is come. We are going to drive the English into the sea, and will have nothing more to do with you." After the repulse of this attack, the enemy fell back upon Jama Mano, and Tiama, at which latter place (consisting of five towns built all together), an immense stockade and fort was ereeted. The walls of the latter consisted of mud quite six feet thick and about twelve feet in height, and must have taken a considerable time to build.

On the 9th of May, a mixed force of fifty men of the West African Regiment and Frontiers, under the command of BrevetMajor O. H. E. Mareseanx (Shropshire Light Infantry), left Sierra Leone with the object of strengthening the garrison at Kwalu. The force was a small one owing to the fact that only thirty carricrs conld be obtained, and these came from the Gold Coast. A halt was made at Songo town, which is about thirty-five miles from Freetown, where it was found that additional earriers conld be obtained. The enemy were reported to be in large numbers between Rotifunk and the Ribbi River, and so reinforcements were obtained. These consisted of seven European officers and 453 men, fifteen of whom were European soldiers. The others consisted of the Sierra Leone Royal Artillery, with one 7 pounder R.M.L. gun, Royal Engineers, West India Regiment, West African Regiment, Frontiers and Army Service Curps. The late Major-General Sir E. R. P. Woodgate, K.C.M.G., commanding the troops in West Africa, accompanied the columm. A raft had been prepared on the Ribbi River at Makweh, and on the 13th of May the column erossed the river and eamped at Mabang for the night. Next day at dawn the column marehed on Foioa, where the advanced guard came upon the enemy, who occupied 


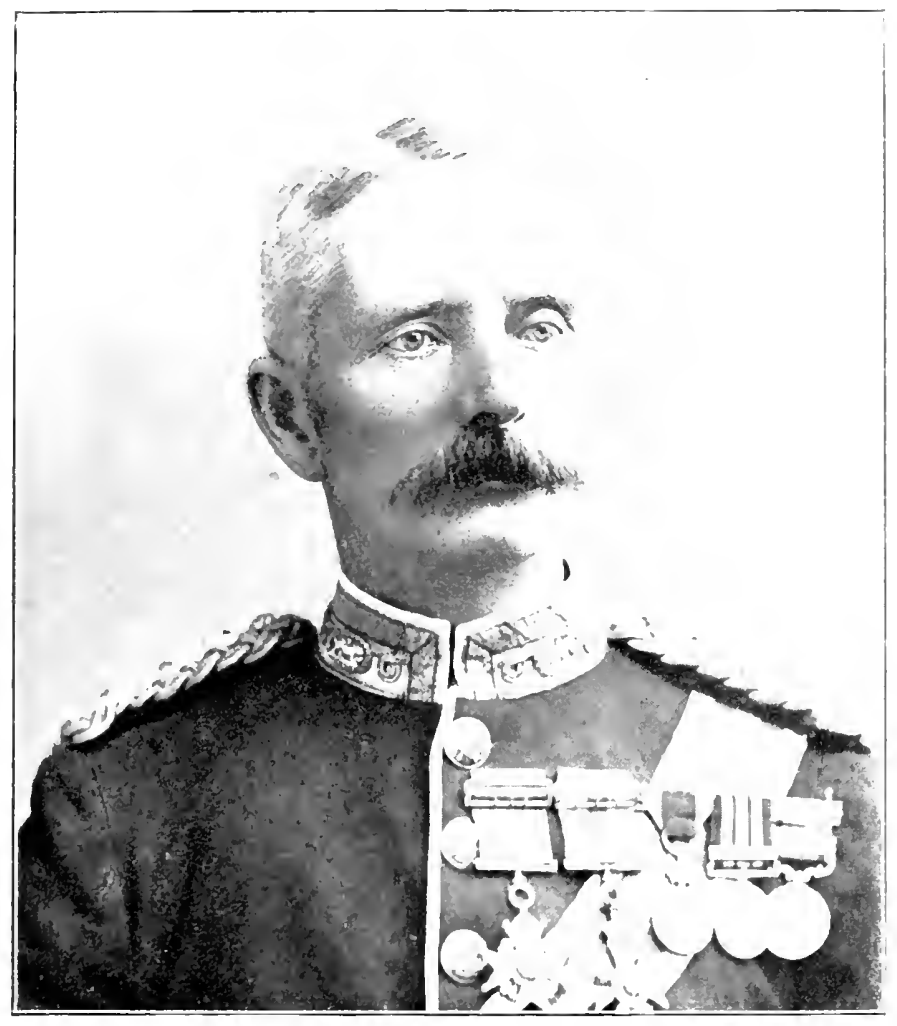

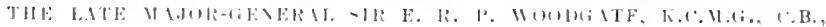

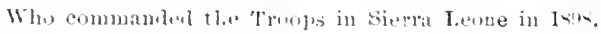



five stockades off the road. After some fighting, which resulted in our having one soldier and one camp follower killed, and two soldiers womided, the stockades were taken and destroyed. A camp was pitched at Noyamba, where a halt was made for the night. Next morning the column pushed on to Kotanga, which was defended by a stockade built across the road; and the taking of it resulted in Captain Cave Brown Cave being severely wounded. Rotifunk was reached on the same day. This place was found to be in ruins, and the Mission house destroyed. It was here that the European missionaries and others were murdered, as mentioned in a previons chapter. A large amount of ammunition had been expended during these skirmishes, and more troops were required before proceeding to Kiwalu. Accordingly, a further detachment of the West India Regiment was sent up on the 20th, and Rotifunk was put into a state of defence.

On the 21st of May, the colmm started for Kralu, leaving twenty men of the West African Regiment to garrison Rotifunk. A camp was formed that night at Moyamba. The following day Kwalu was relieved, and another party of twenty men of the West African Regiment was left between this station and Rotifunk.

It was reported that a very large number of Mendis had collected at Tiama, consequently a force consisting of three European non-commissioned officers and 19 native soldiers of the Royal Artillery; with 7-pounder guns, two officers, one European non-commissioned officer and thirty-eight men of the West African Regiment; two officers and eighty noncommissioned officers and men of the Frontier Force, with rocket tube; and 650 Friendlies (Mendis and Jomis) with their war-chiefs marched for that place. The latter force was armed with swords and with as many guns as were ubtainable. At noon the bank of the river to Tiama was reached, where a small village situated at the ford was found to be very strongly stockaded. The river at this part is about 200 yards 
wide, and the passage was forced by the Frontiers, assisted by the Friendlies, under cover of the guns and rockets. The enemy showed great indifference to our fire, exposing themselves repeatedly in the open, and must in consequence have suffered severely. Upon our advanced party, however, nearing the far bank, they abandoned the three stockaded villages and fled, being hotly pursued by our Friendlies. Our losses in this action were very small, being three Friendlies killed and three wounded, and three Frontiers severely wounded.

The Friendlies continued the pursuit of the enemy, taking and burning the stackaded town of Senahu, and destroying several others. They did excellent work, and there is no doubt that our casualties would have been much heavier and our task much more difficult had we not had their assistance.

Having attained its olject, the column returned to Kwalu on the 26th of May, passing through Banguma and Makori, and, leaving reinforcements and ammunition there, reached Rotifunk two days later.

This expedition put an end to all resistance in the immediate neighbourhood of Tiama, one of the strongholds of the Mendis in this part of the country. It was nevertheless discovered that the large towns of Jama-Mano and TiamaWarra were still full of war-boys, and a party of Frontiers with a number of armed Friendlies were despatched to these places on the 4th of June. This force was surprised, however, by a large number of the enemy, resulting in several Friendlies being killed and some Frontiers wounded. Reinforcements were sent, and a lot of fighting took place at Tiama-Warra, where the enemy suffered severely. This force was unable to reach Jama-Mano, so returned.

On the 7 th of June the colnmm that had relieved Kwalu under General Woodgate returned, and reported the capture of Jama-Mano. The result of this, and especially the taking of Tiama, was that the powerful chiefs Bai Simera, of Maioppa, and Bai Kompa, of Yele, threw in their lot with the 
Government, and thenceforward rendered valuable assistanee. The enemy were now driven out of the large town of Gendimah, and the stockades destroyed by these chiefs.

Shortly after these events the District Commissioner of Ronietta received orders to proceed immediately to the relief of Panguma, which, as I have previously stated, was cut off and surrounded by a very large number of the insurgents. Consequently a force eonsisting of seventy-five picked Frontiers and native gunners, with one 7-pounder R.M.L. gun, fifteen armed Court messengers, and abont 300 armed Friendlies, mostly recruited from the Yomin tribe, left Kwaln on the 12th of June under the command of Major E. D. H. Fairtlough, C.M.G., D.S.O., for Panguma, in the heart of the Upper Mendi country. Owing to reports having been receired that a large force of the enemy were concentrated at a town called Longi, the column passed that way, and when within three niles of Gagboro, which consisted of three towns, the enemy opened fire from an ambush. After repelling them, our men charged and they were driven out, and the town, which was defended by three rows of carefully prepared stockades, was taken. Our casualties were, on this occasion, four Friendlies lilled and two Frontiers and two Court messengers wounded. From Gagboro the column marched on to Longi, and, finding the road blocked by obstacles all the way, which necessitated a new one having to be cut, a laalt was made at this town, which was found to be deserted. Here the column birouacked for the night, and were sniped at whenever anyone showed himself ontside the enclosure. The following day Kambona was reached without opposition, and here a halt was made for the nightit. Pushing on next day to Monidu, a ferry had to be crossed, and, all the canoes having been removed, rafts had to be constructed. In these the advanced suard crosscd, led by Captain H. de L. Ferguson, D.S.O. On the other bank the scouts of the advanced guard diseovered a eanoc, and, while preparing to launch it, were attacked. This attack, 
which was repelled, resulted in the loss of two Friendlies killed and three wounded. Meanwhile the canoe was launched, and the remainder of the column took it in turns to cross, many of the Friendlies plunging into the water and swimming the stream. The baggage having been left behind at Monidu, the column camped for that night in a rice field close to the river. At dawn Major Fairtlough proceeded with the advanced guard to Gendima, and while halting there for the baggage was attacked, one Friendly and one Comrt messenger being killed. The column was now in the territory of the great Chief Niagna, and severe opposition was met with for the whole of the journey. Camping that night at Gendima, in order to allow the baggage to come up, the column marched again at dawn, finding the road blocked and impassable, and the bush on either side alive with the enemy. There were still eighteen miles to be done, and the movement of the column was here exceedingly slow, a road having to be cut through the bush and the pioneers defended from the repeated attacks of the enemy at the same time.

The column, having covered thirteen miles, every few yards of which were contested, found it was impossible to push on further, and was obliged to bivouac again in a rice field. Next morning the march was resumed, when the road was again found to be blocked and impassable, and a new one had therefore to be cut as before. At Dodo the column was attacked, and the enemy did their utmost to prevent the relieving force from reaching Panguma. However, as before, they had to retire, and that morning the force marched in triumph into the station.

Here the defenders, who were under the command of Major J. E. C. Blakeney, were found to be in a very bad way. They had been surrounded by thousands of the insurgents, who had attacked them repeatedly, and their food supply had run short. Every one was living on half rations, which consisted chiefly of rice. The garrison were also short of ammunition. The 


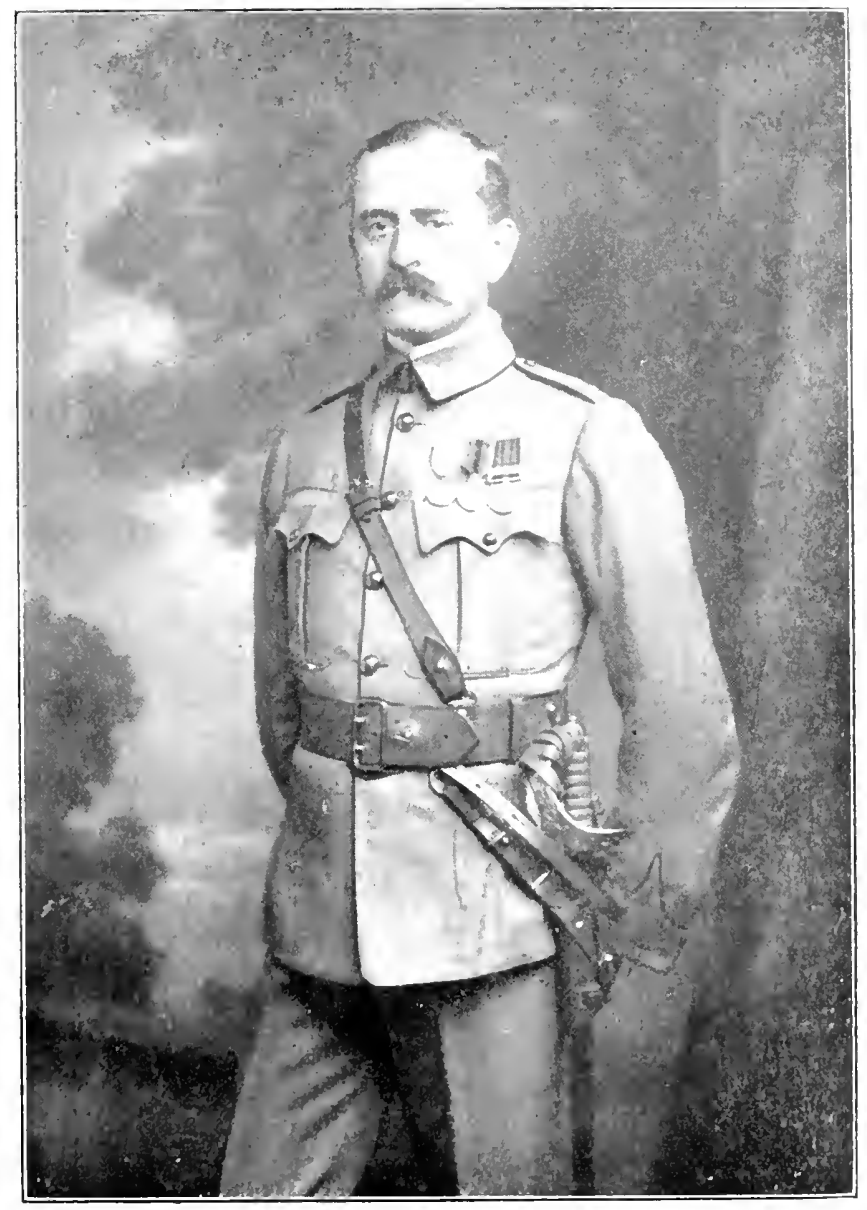

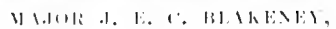

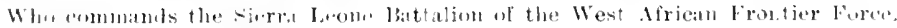

Plunding lillintt a Fin. 

barracks, in which were the officers' quarters, were stockaded, and to this they probably owed their salvation. There was a large number of casnalties among the men, and the medical officer, Dr. O. Horrocks, had worked night and day attending to the sick and wounded, helping them in their suffering.

Major Blakeney had occupied this perilous position for two months, and it speaks well for the men he had under his command that he succeeded in holding the station against such heavy odds. In fact, throughout the rising the troops engaged, including the West India and West African Regiments, behaved exceedingly well. The men of the Frontier Force were often left in small detachments in dangerous and difficult positions, and invariably proved themselves worthy to be classed with the best soldiers of the Empire. Colonel Sir Frederic Cardew, in his despatch of May 1, 1899, upon the Force says: "But for the courage and tenacity with which they held, mder the gallant leading of their officers, the seats of Government in the Protectorate, the whole comntry would have had to be reconquered at great expense during the dry season which followed. During the disturbances they have suffered severely, for no less than fifty were killed fighting at their posts and 73 wounded; and, notwithstanding that they were fighting their own kith and kin, there was not a man that proved himself a traitor in the whole force, but, held together by the bonds of discipline, confidence in their officers, and strong esprit de corps, they all did their duty loyally and comrageously.",

The Governor" continnes: "As to their officers (and with them I would include the District Commissioners and Surgeons), I cannot too highly commend them for their derotion to duty and gallant bearing under very difficult and trying circumstances; left in isolated positions to act on their own initiative, cut off from all communication, and surromed by numerous and savage foes, there was not one who did not prove himself worthy of the trust imposed in him. They all 
upheld, from the highest to the lowest, the highest traditions of the British officer for coolness, courage, daring, and resource in danger."

Meanwhile a force, consisting of four officers, 84 West India soldiers and Frontiers, 150 armed Friendlies, and 110 carriers, under the command of Captain J. E. S. Woodman, left Bandajuma on the 21st of Jume, and, passing by way of Tikonko, Gerihun, and Koranko, reached Panguma on the 27th of June, four days after the arrival of Major Fairtlough's column. No opposition was met with during their mareh, and the force returned to Mawfé on the 3rd of July, leaving behind thirty-three Frontiers and as much ammunition as possible.

The exertions of Fairtlough's relieving force were by no means over, and after remaining for five days at Panguma, that officer left the station for the return journey, accompanied by sixty Frontiers, five of whom were womded, five men of the native Royal Artillery, three armed Court messengers, and about three hundred armed Yonnis.

The column did not return by the same route by which it came, but passed via Lalehmn and Gihun. At Lalehnn opposition was met with, and the party found the road leading to the town blocked by a strong stockade rumning right across it. The tom was also stockaded. All the stockades were, however, destroyed, and the Friendlies, rushing into the bush as usual, killed several of the enemy, losing in the fighting two of their own number killed and three wounded. At Gihm most determined opposition was met with, the enemy defending their stockades until the last. Here, as in several other places, the natives made good use of bamboo spikes in the paths leading to the town. These spikes are as a rule extremely sharp, and some of them are poisoned. They are firmly placed in the ground, and are concealed by a covering of leaves, twigs, or earth. The spikes are exceedingly dangerous, and make very nasty wounds. At the same time 
they have a most demoralising effect on a body of men who wear no boots, such as the West Africa Frontier Force, especially when they are rushing to take a stockade or charging. The casualties at Gilum were three Frontiers and four Friendlies wounded.

Passing through Dodo again, where there was some skirmishing, the column pushed on to Goma, which was found, as usual, to be stockaded. On the stockade being turned, the enemy fired the town and fled. Here the column camped for the night. Pushing on next day they found the enemy's tactics were to set fire to the houses as the force advanced. The column had now reached the Big Boom, or Sewar River, which was a serious obstacle, as it had to be crossed. A determined resistance was met with here, and a hot fire poured into our force by the enemy, who had built a strong stockade in the further bank. However, our columm, under cover of rifle fire, crossed the river, and charged and took the stockade, the Friendlies rushing into the bush and chasing the enemy in capital style. Pressing on, they came upon another stockade, abont a hundred yards from the town of Jaiwa. The enemy were driven out of this also and fell back upon the town. In the namow path leading into it, however, three more strong stockades were found. These were stubbonly defended, and immediately they were taken the enemy set fire to Jaiwa, which was close by, in order that the column should have no place to sleep in that night. Here, nevertheless, the force bivonacked and remained until the following day, while parties were sent ont to endeavour to locate the whereabouts of an influential chief named Bundu. This man liad been an ex-political prisoner, and it was reported that he was in command of a large war-camp in the neighbourhood. However, the scarch was fruitless, neither the chicf nor his war-camp being discovered, although some skirmishing took place between our men and his followers.

The next day the march was resumed, the columu being 
fired upon nearly the whole way, and the towns always burnt before $\pi$ re reached them. Our force prepared to bivouac again in the open. Anyone who knows what this country is like in the middle of the rainy season will be able to appreciate the hardships and difficulties which such a necessity entailed.

From Jaiwa the column marched on to Yabaima, where constant opposition was met with, and the taking of two stockades cost us one Court messenger severely wounded, one Friendly killed and three wounded. Yabaima was reached on the th of July, and it was seen to be in flames as the column neared the torm. Information being received that the enemy were in force at Jagbaima, and engaged in a big war-dance, the column marched for this town, which was a large and strongly stockaded one. The opposition here was found to be very strong, and after the triple stockade had been taken, our men were thrown into confusion upon suddenly coming into the midst of a forest of sharpened spikes. No ferrer than five Frontiers were badly hurt by these obstacles, and several of the Friendlies suffered severely. The town was taken at the point of the bayonet, and sixty-five of the enemy lay dead around it.

On the 6 th of July the force pushed on to Xomundu. This consisted of three large tomus in one, and was as usual strongly stockaded by a triple row of fences. The action commenced by the fire of the 7-pounder gun, and by rolleys from the men. Closing in, one section under Captain Ferguson, D.S.O., took the right side, another, under Major Fairtlough, the left side of the line; while a third section, accompanied by a number of Friendlies, cut their way through the centre. Here a hand-to-hand fight took place betreen the Frontiers and the enemy, and when the town was taken by our men no fewer than three chiefs and 115 of his followers were found to have been killed. Among these chiefs was Yombasu, the "big warrior," who, as I have before remarked, led the attack on Krralu. 


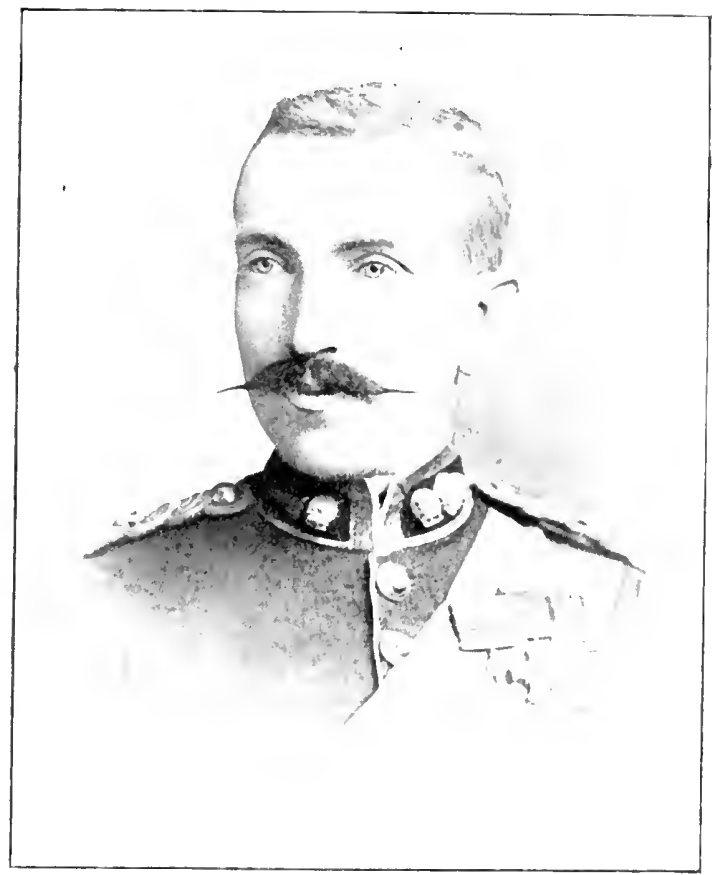

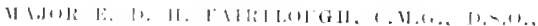

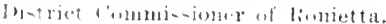



This action practically put an end to the fighting, and the column met with no further opposition on its mareh down to Kwalu, at which place it arrived on the 10th of July. That same morning a force of Frontiers, accompanied by Dr. T. Hood, now Senior Medical Officer in Freetown, had left for a town called Tonia, which they found stockaded, and after some figliting, had taken.

A number of the eliefs now began to tender their submission, and although there were still war-camps and small maranding parties seattered about the district, no serious opposition was again met with. The people in this part of the country had also been shown in a most practical and forcible way that they are mnable to withstand the soldiers of the Great King, black though these soldiers were, and when led by British officers. The natives had, however, fonght well, stubbornly and bravely, and who can blame them? Did they not think that they were fighting for their country which, they wrongly conceived, was being taken from them by the white man?

Nor must we forget the great services rendered to our columns throughont Mendiland by the number of Friendlies who accompanied them. The casualties were always higher among the Friendlies, owing to the fact that they used to rush and follow the enemy into the bush, which the Frontiers and others were not permitted to do. There was more assistance rendered in this district by the ehiefs than in both Bandajuma and Panguma. While Bandajuma only received real assistance from two inportant ehiefs, namely, Momokiki and Momo-jah ( $\mathrm{I}$ do not include a number of minor chiefs and others belonging to these two paramount chiefs), the Ronietta District was actively assisted by Bai Simera of Maioppa, Smart of Malera, Fula Mausa of Yomini, 'Tambawa of Kenema, BangiLegbi of Bunkeri, Momo Gittai of' Kendema, Nancy 'Tucker of Pagru, and Madam Yoko of Senahu, all persons of power and with large followings. This assistance was, of course, 
of the greatest value, not only to our local forces, but as an example and for the moral effect it produced upon the insurgents, who were fully aware that a number of the most important chiefs in their comtry had joined the Government and were fighting against them. Besides those who were actually engaged against them there were others professing to be neutral, the most important being Sembu Kamara of Gendima, Bai Kru of Maban, T. N. Kalla of Shengai, Bai Hal of Malal, and others. It is exeeedingly donbtful, however, if these people were really neutral. Although it is believed that they took no active part in the fighting, there is a certain amount of evidence to show that some of these chiefs were prominently concerned in the secret meetings of the Poro, which were held so constantly for some time prior to the outbreak. No faith, however, can be placed in the professed nentrality of the powerful chief, Sembu Kamara of Gendima.

Besides the Ronietta chiefs showing a tendency to submit to the Government, those in several parts of the Bandajuma District were holding constant palavers with that end in view, and many of them even sent in a number of arms to Mawfé. Although the British terms were "unconditional surrender and total disarmament of the population," these were aceepted by several of the chiefs; and many important arrests were made of murderers and others. There were a great number of people rescued in these expeditions, and by the column that went to the relief of Bandajuma, over one hundred people being saved, most of whom had been hiding in the bush, or were even then in the hands of the Mendis, their death laving been, for some reason or other, postponed. These included traders, women and children, and Sierra Leone missionaries. 


\section{CHAPTER XVII}

THE END OF THE RISING

"Let us hear the conclusion of the whole matter."

TOWARDS the end of Angust I took a party of thirty-five 1 Frontiers into the nortli-east corner of the Bandajuma District for the purpose of: (A) Effecting the capture of certain ehicfs and others who were charged with murder; (B) Punishing the insurgents who were reputed to be in force on our side of the Liberian border; and (c) Endeavouring to bring in several chiefs who were hiding in the bush, and who were willing to surrender, but afraid to do so.

It was now the middle of the rainy season, and marching at this time of the year is worse than mupleasant. Moreover, a number of towns had been burnt and destroyed, so it was not at all certain, when making for a town, whether it would be found to be standing or not. My ronte lay from Bandijuma, across the Wanje River to a small place called boombe, in the Peje country, some foutecn miles distant: from there to Buarbabu, on the Moia river, in the Foya comntry, thence to Gorohn, in the Tunkia, Geghima, Mendikama, and finally to Malema and Gore, in the Gola country, on the Liberian fronticr.

After passing the Koya country, one begins to get into Upper Mendiland, and as soon as the Tunkia is reached a 
magnificent forest is met with, consisting of tall and massive trees. In this forest, owing to the thickness of the foliage interlacing overhead, there is always a gloom, and even at midday it would be possible to march along without wearing a hat. Here, and especially in the rainy season, elephant are found, which are hunted and killed by the natives, who make bangles out of their feet, by burying the pad until it becomes quite soft ; they also trade in ivory, and make fetish "medicine" out of several parts of the body.

A great number of towns we found to be destroyed, although here and there was a barri, or small bamboo hut, left standing. On arriving at Juru, in the Gowra comntry, we found that the people, who were unaware of our being so close, had only just had time to clear out, even leaving, in their haste, their rice cooking on the fire. It was in the Gowra country that I wished to bring the paramount-chief, Batte-Kakka, from the bush where he was hiding. This man had great power thronghout the Upper Mendi country, and as long as he remained where he was, the country within hail would never be settled. I endeavoured in every way to find ont his hiding-place and entice lim forth, but without result, as we could find no one about from whom we could inquire. One day, however, a native man was canght by one of the Frontiers, spying at us from behind a tree. When he was brought up to me he seemed so much afraid that he could not talk. Telling him not to fear, that no harm should come to him, I asked him where the chief was. He denied knowing anything about him. Believing this was false, I told him that if he would promise to take a message from me to the chief, I would release him at once. This he very readily consented to do, and next day, while bivonacking at a town called Magbama, a messenger came from the chief, who informed me that he was too sick to come ont of the bush. However, after several messages had passed between us, and I had given him ny word that no liarm should come to him, 



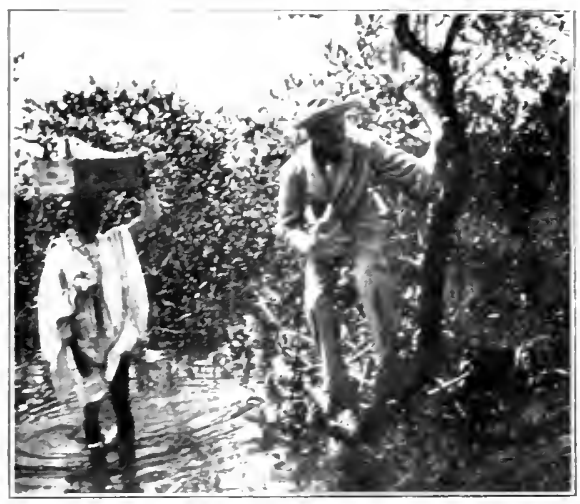

TIIE HUII- IS THE RIIVI-EA-II ARE

WIEY FIU, 1,5 ,

(I'. 191 .

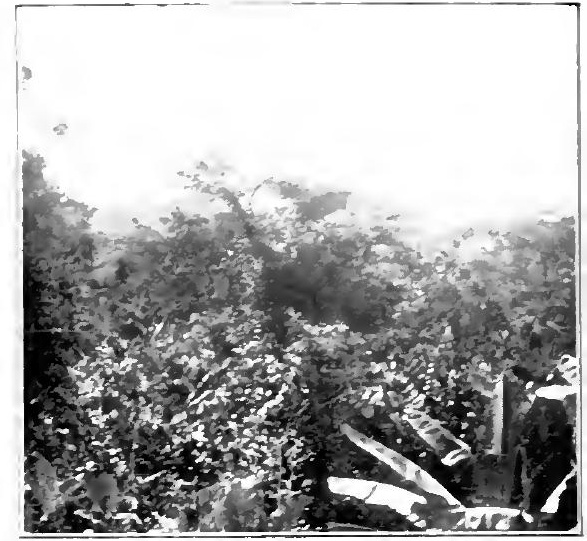

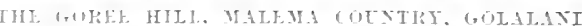
$(P$.

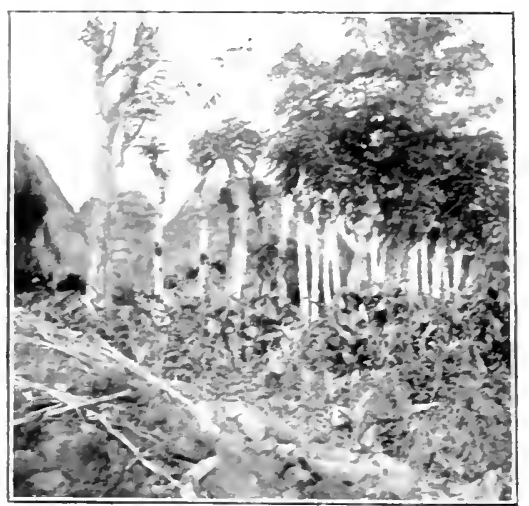

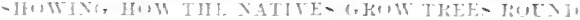

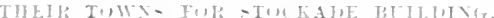

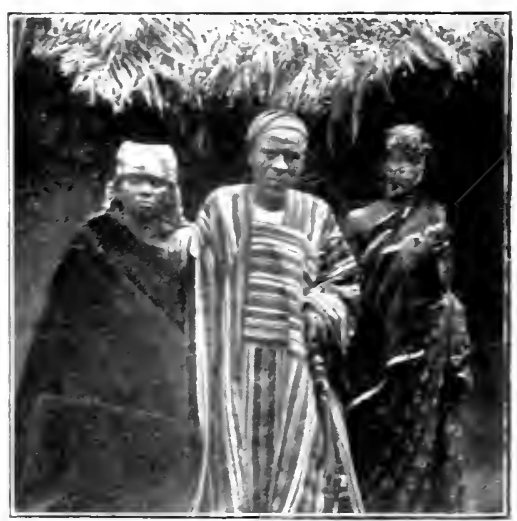

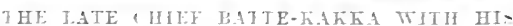
IWU FATUTHITE WIVF= 
the chief consented to meet me at Mendikama, a large town in the Upper Gowna country and about twelve miles from Juru. At ten o'clock on the fourth morning the chief arrived in a hammock, bcing completely hidden and swathed in rugs and blankets, which is the custon among some chiefs when they travel. Having told Batte-Kakka the object of $111 \mathrm{y}$ mission, and informed him that the country was becoming settled again, he agreed, after some time, to emerge from the bush, and rebuild his town Pujuhun, which had been burnt. There was much rejoicing in the town that evening, and a regular pandemonium of tom-tom playing and singing was kept up the whole night through. Batte-Rakka also promised to do all he could to bring the people back into the towns and further to assist the Government in apprehending several murderers who had fled from Lower Mendiland into the dense forests by which this comtry is surrounded.

From that day Batte-Kakka and I have always been good friends, and on my returning to this comntry two years afterwards, I went up to see him. He was genuinely delighted to see me, and one of his first remarks was to recall the incident of the manner in which I "pulled him from the bush" after the war. Although he was sick at the time, I got him to stand while I photographed him leaning on the shoulders of his two favourite wives. Shortly after this he died, and I was the last white man lie had seen or spoken to. He was a very clever man, and since the rising one of the nost genuinely loyal chiefs the Government had ever had to deal with. 'This was in November, 1902.

Continning our journcy, we reached the Jarwe country, upon the border of which we were fired upon. Pushing on, we arrived at the paramount chief"s town ealled Niama, which we found to be deserted, though there was evidenee about to show that it had been quite recently occupied. Every endeavour was made during my stay in this country to get the chief, whose name was Vandi Vong, to return, but without 
arail. A smart watch lrad to be kept during the three nights we slept there, as the place was full of war-boys, and there were sereral alarms in the night. The forest all round was tremendously dense, and it would hare been extremely unpleasant to have been attacked while up in this part of the country with so small a number of men. Howerer, no such contretemps took place, and Chief Vandi Vong, who at that time wished to come out from his hiding-place but was afraid, has since been a very loyal, as he is a most important and useful chief to the Government. He allowed me to take his portrait when I visited his country last December.

The next place I went to was Madema, in the Nalema country, some sixty miles in a straight line from Bandajuma. This town we found to be filled with people; and although the chief had been mixed up in the rising, he had not taken any active part in it, but had, on the contrary, managed to save the lives of one or two English-speaking people, who had made their escape into this country. This chief, whose name was Pambu, came ont to meet me, and since that time we have been very good friends. Of all the many native people I have met since I have been in Africa, there is none $I$ have liked better or respected more than this old chief. I can only describe him as a dear old fellow, and his delight on seeing me again on my return to the country in $1901 \mathrm{knew}$ no bounds. He presented me with a cow, several country-made cloths, and so much rice that I had to give back a lot to him; not being able to carry it away. In return I bought him a gun, of which he is immensely proud.

When I was staying in his town towards the end of last year I asked him to allow me to photograph him, but he would not consent to face the camera, telling me he had never seen anything like it before, and was afraid to let me "draw him." His fear of the camera was most amusing, and I am convinced he thought it contained some powerful fetish. However, I managed to snap him when he was not looking. 


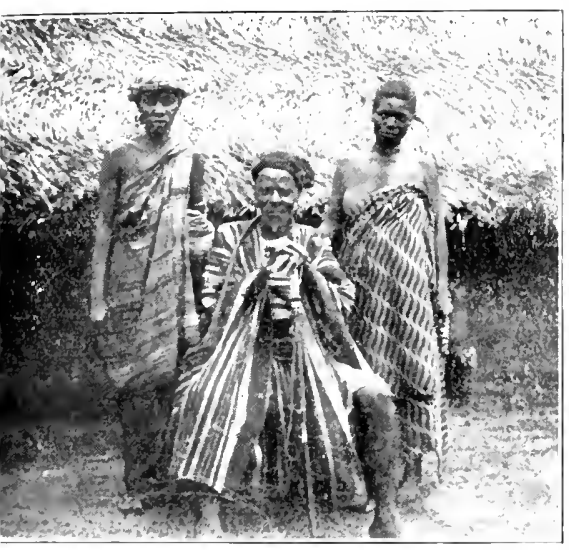

$1111:-$

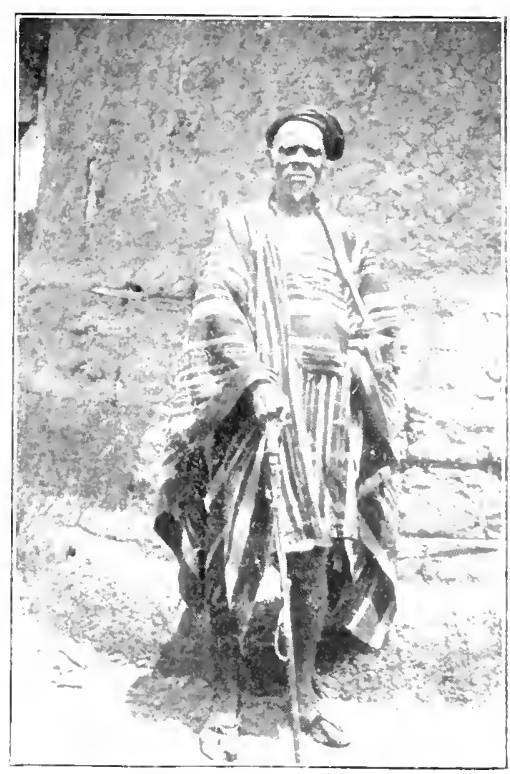

$11 \mathrm{NH}-111 \mathrm{~N}$.

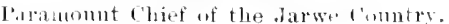

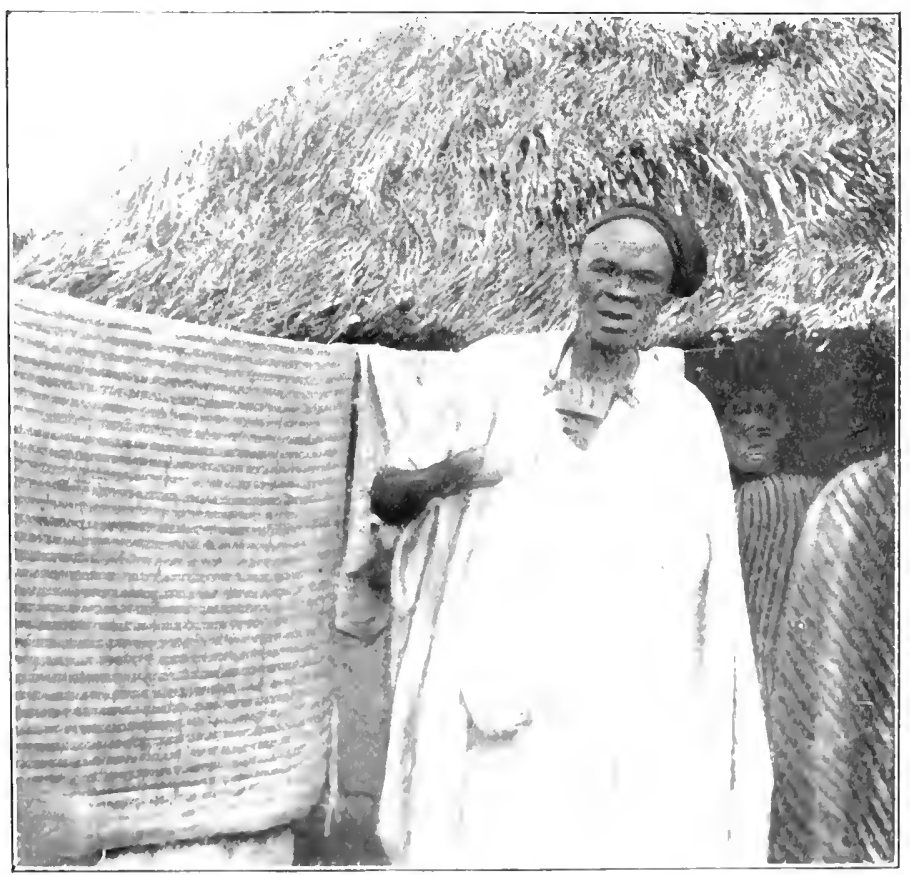

111131 , 

The cloth shown in the picture belongs to my camp bed, and had been placed in the sun by my boy to air. It forms no part of the photograph, but I liad to take the chief wherever I could get him, and it happened to be there.

It was exceedingly interesting to talk to Chief Pambu, which I have done by the hom together, of course by the help of an interpreter. He told me he had never been further than Bandajuma (the headquarters of the district), which he said was a very long journey, and to do that, he added, was a very big business, and it took many days to prepare the fetish which had to be taken with him to see him safely there and back. He was very much interested in my telling him about the ocean-going steamers, and from the remarks he made he showed me that he could have no conception of what an ordinary steamship was like. When I asked him if he would like to see England, the white man's country, he told me that he had no desire to travel far away. He loved his comntry and his people, which he must stay and look atter, and which he never desired to leave. I can well imagine him loving his country. The scencry here in places was indeed exquisite, and used to give me infinite and never-ending pleasure. It is, in fact, an education of itself. The surrounding forest, in its vast and solemn magnitude, impresses one with a feeling near akin to awe, and when one stands and gazes in its grand solitudes, the thought comes home to one, how great and awful must be the Maker Who can create such majestie scenes as these. For every leaf, and tree, and insect, has its meaning and its place; every stone and twig helps to make the one grand whole, and has its ordained part, which one day in the miknown patlis of time it is destined to fulfil.

"This is not solitude, 'tis but to hold

Converse with Nature's charms, and view her stores unrolled."

Such secnes and sturoundings as these leave a deep and 
abiding impression upon the mind of the thoughtful man. Especially is this so when one leaves these solitudes and then finds one's memory continually drifting back to the time one spent in the wild African "bush," till at last, in spite of the climate, and the thousand and one inconveniences (and that is a mild term) that have to be endured, one feels an unaccountable desire to go back to it all. It does not, of course, affect everybody in this way, and I am here speaking chiefly of myself in this regard, but $I$ have known and heard other men say the same thing also. There is most certainly an extraordinarily attractive charm about it all. The going home again, after spending a year or more in the lonely surroundings of the interior of West Africa is, of course, delightful, though sometimes, as is often the case with other matters in life, the anticipation affords more pleasure than the reality. In Europe, and especially in the large cities which number their inhabitants by tens of thousands, one is struck with the artificial mode of life; with the hurrying and bustling crowds; with the unreality and shams of modern so-called society; and, above all, with the many poor and squalid streets and the distressing sights of poverty and suffering that meet the eye at every turn. It is then that one thinks of Africa's silent haunts and virgin beauty. I have seen 110 real poverty in savage Africa, except when it is brought about in the more civilised parts by the advent of the white man and his ways. And this civilisation, what is it all leading to? We are trying, in my opinion wrongly, to thrust European civilisation and European ideas upon the African and upon a country for which our modes of life and customs are entirely unsuitable. From my experience, ninetynine times out of every hundred when you "Europeanise" the negro you make an inferior man of him. He is quick at picking up our vices, and our ways of dealing with him are such that he sees very little of the virtues that centuries of civilisation have given to us. 
At this time of the year the rivers are all swollen, and even the streams, which in the dry season can be stepped across, become imfordable, and often raging torrents. All this portion of the country is covered with immense forests, which extend for miles into Liberia. These forests, impassable to Europeans, have many small tracks, only known to, and used by, the native hmuters. Chief Pambu maintained a number of hunters who used to get a good deal of ivory for him. During my visit to his part in 1902, an elephant had been killed a few days before my arrival in the town, and the chief presented his head elephant hunter to me. This man, whose name was Fassimbn, is credited with having slain over two hundred of these mighty kings of the forest. He was only armed with a long barrel muzzle-loading gun of unknown antiquity, and it is marvellous indeed how these natives are able to go into the forest on a hunting expedition armed only with these obsolete old weapons and slay the mightiest of living animals, which sportsmen possessing the most modern breechloading rifles are not always able to do.

These hunters, whose only covering is a kind of dark brown cloth coat somewhat resembling a sack and peculiarly harmonising with the surroundings, sometimes spend weoks together in the depths of the forest when pursuing game. When shooting elephant they generally hunt in twos and threes, and their modus operandi is to stealthily approach the game when it has been located, gradually creeping up upon the leeward side. So quiet and cantions are they in their movements that they are often able to approach within fifteen paces of the elephant before they fire. Their long barrelled guns are usually loaded with an extra charge of powder behind a kind of spear consisting of a wooden haft about three feet long, and a solid triangular blade of abont three inches across in the widest part. This is incerted in the barrel of the gunr. They aim this usually muder one of the forclegs of the elephant, and if it does not bring lim down at once, his 
rushing off with the spear sticking into him, and catching in the ground or against trees as he careers madly forward, tears and lacerates, and often cripples him into helplessness. The hunters will often chase a wounded elephant for days, being easily able to follow their game by the huge tracks and the blood flowing from the wound. It seems marvellous how these people are able so successfully to kill so many elephants in this way. In the first photograph may be recognised the hunter Fassimbu; the picture was taken very shortly after he had returned from a hunting expedition in Liberia. The second photograph shows other elephant hunters belonging to this part of the country, nearly all of whom are dressed in their peculiar hunting costume. Every one of these men has killed several elephants, some accomplishing this singlehanded.

Two of these hunters are mere boys, and the chief informed me that they all possessed a wonderful "medicine," which enabled them to be so successful in their hunting expeditions.

During my stay in this part of the country in 1902, I was very anxious to try my luck with the elephants, which were all round us. I consequently journeyed down to a small village called Goree, some ten miles to the east of Madema, and situated in the midst of gigantic bush. The country is exceedingly hilly here, and the forest seems to get larger and grander the farther East one goes. This town is near the Morro River, which the chief told me had never been crossed at that part by any white man before. Beyond was the impenetrable Gola forest, where I was informed no one lived excepting hunters and elephants. This river was, at the time I visited the place, very swollen from the rains, and flowed extremely rapidly. There were no canoes; the natives, when they did cross, used to do so on corkwood rafts, one of which was tied to a tree close by. For some time I could not get any of the people of the village to cross at this part, all declaring that a very powerful devil lived there, and that it 


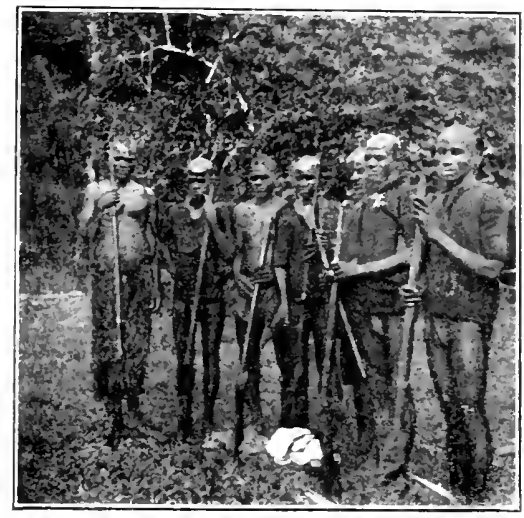

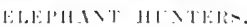

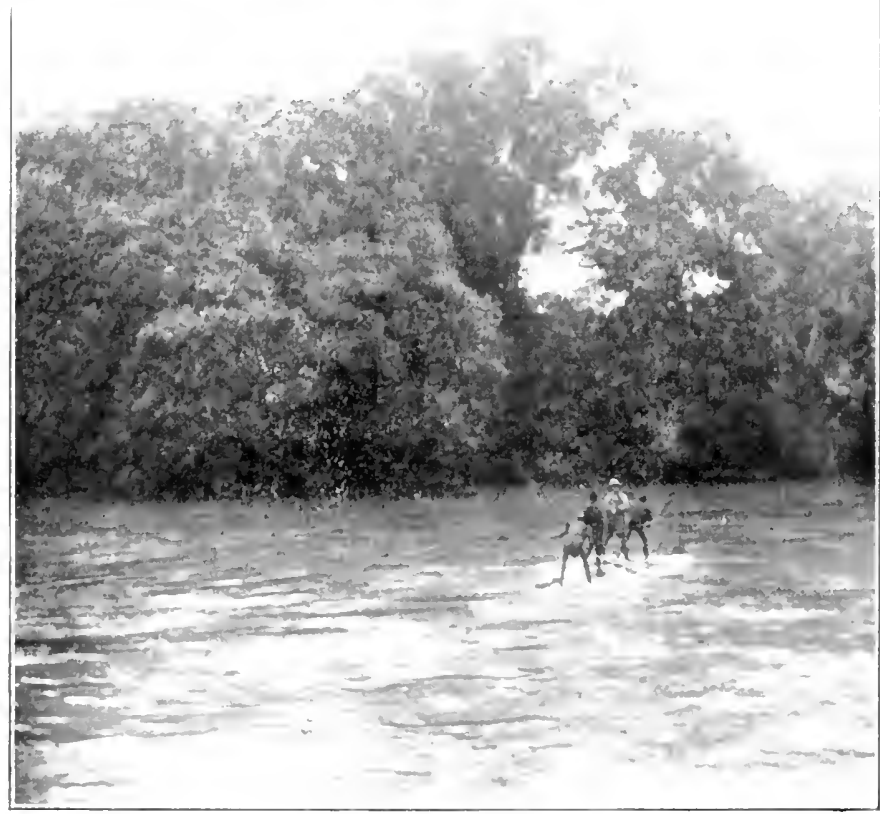

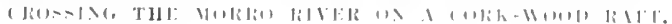



was therefore dangerous to do so. At length, however, by dint of a bribe, I persuaded two hunters to take me over on the raft. Starting from the bank, one man stood at each end of the raft with a paddle in his hand, myself and the Court messenger who accompanied me being in the centre. The stream took us down with a rush for about a luundred yards, but the hunters were very skilful in managing the raft and paddled safely across. Here the giant forest came down almost to the very water's edge, but the hunters, who acted as our guides, pointed out a narrow track along which we were to proceed. For some hours we marched through this wonderful "bush," occasionally coming across the huge beaten tracks and marks made by elephants. I saw nothing of them, however, and the liunters informed me that it would be necessary to sleep in the forest and go on at dawn. Not having the time for this, having other matters to attend to, I was obliged to turn back and had regretfully to give up my exploration and hunting trip in this most interesting and unknown part of the combry. We returned by another route, the path of which was so narrow and so intricate in its windings, that without the aid of our hunter guides we conld not have got along at all. The photograph on the next page is a snapshot taken of the corkwood raft while crossing this river.

Reverting now to my former journey. From the Malema comntry we passed throngh Taima, Patania, Jeme, Lalehum, Jagarma, Beribu, Konkon, to Bulna. All along this route the scencry was exquisite and the forest grand in its immense and stately beanty. Most of these towns were standing, but not a soul was to be seen in any of them. At Buhna there used to be a small out-station, but nothing of it remained and the town was found to be burnt. In former years Bulmia was a very strongly stockaded town, and was subject to repeated attacks from the wild Gola tribe, who were continually making war against the Mendis for the purpose of obtaining slaves. This 
was the reason that a small detacliment of Frontiers was maintained here, and for some years now no such raids have taken place. From Bulma we marched on to the village of Fangiwalahun, and thence back to Daru, Damawuru, and so to Gorahun again. No native people were met with, although we found the road between Daru and Damawuru blocked and impassable and had to cut a new one througl the bush. Between Gorahun and Samatira we were fired at; but on returning the fire nothing further oceurred, and as we could not see a soul, we continued our march, passing vîa Bandasuma, which was bunt, and crossing the Moia river to a small town called Falaba, which was also destroyed. Here we camped for the night, the men erecting temporary shelters of palm leaves. That night it rained in torrents, the water dripping and splashing through my thin roof in a dozen places at once. None of us got much sleep and we all felt miserably chilled. Glad we were next day, when we returned to Bandajuma, to find ourselves under a dry roof once more.

A few months later, while retuming with Dr. A. F. M. Berkeley and a party of Frontiers, from another visit to this same part of the country, we arrived after a long march at a deep stream, about a mile from Bandasuma on the Moia river. The time was about five o'elock in the afternoon. This stream was, owing to the recent heavy rain, running very swiftly, and the native bridge which had spanned it previously had been swept away by the rising of the water. Here we found all the carriers and the advanced guard sitting down by the stream, being, they said, unable to cross, as the river was too deep and ran too swiftly. There was no town belind us for quite fifteen miles, and unless we intended to pass the night in the open, that stream had to be crossed. We therefore began to cut wood with the idea of making a raft; there was, however, no suitable timber close by, even if there had been we had no axe to cut it with. At last, after about an hour, in some wonderfnl manner the Frontiers and carriers 
had managed to put together a kind of raft. On launching it, however, it was found to be unevenly balanced, and would not float. To add to our troubles just at this time it began to rain. It came down in torrents. As we were hauling the raft back to land, one of the creepers with which it was bound gave way, and the whole thing went to pieces. Darkness had now set in, and we were in a cold, wet, miserable condition. A large table was next experimented with, which, to our joy, we found would float on its back. Two of my tin boxes were carefully placed on the table, one of the men having previously managed to make his way across the rushing flood to the opposite bank. A long rope of bush creeper was now found, and by the aid of a heavy stone was flung over to the man on the far side. This was in turn attached to one of the legs of the table, and when all was ready, it was gently towed ont, I holding my breath as I watched my bedding and dry elothes in this ricketty boat. It was not to be, however, for just as the table reached the centre of the stream and felt the full foree of the rushing water, it canted, and off gracefully slid my boxes into the river. This added to our other miscries, but more was yet to follow. By some wonderful gymnastic and aquatic feat, the corporal in charge, assisted by the man on the opposite bank, managed to rescue my boxes again lower down the stream, and although everything was soaked and many things were ruined, nothing was lost. Without a light, we could do nothing, and Dr. Berkeley after opening some of his boxes came upon a packet of candles. The next thing was to find a match, and this I could not snceeed in doing, as they were in the boxes that had been placed npon the fluating table. Again Dr. Berkeley cane to the rescue, and discovered a box, and when it was earefully opened, it was found to contain only one match. By going throngh the most elaborate preparations: arranging coats, hats, and other things that wonk be likely to assist to keep ont the wind and the wet, that match was struck, and lit, and so were 
the six candles, all being held close together. For some time we managed to keep this light burning, but we were no nearer crossing that awful Styx.

It was now nearing ten o'clock, and we were all in a most wretched state: some of us making up our minds to remain in that place all throngh the night. At about 11 p.m., however, we were informed that one of the carriers had discovered a portion of the broken bridge about four feet under the water. This on investigation proved to be a thin pole, which seemed to stretch across to the other bank. With infinite cantion, each carrier balancing in a wonderful way his load upon his head, and moving about six inches at a time, all somehow managed to cross the stream. We waited until all were over, and then went ourselves. How Dr. Berkeley got over I do not know. I was unable to keep my balance, and so fell into the water, managing to seize the pole which prevented me from being washed away. By kicking, pulling, and going through all linds of gymnastic performances, I arrived on the other side splnttering, dripping, and cold, where I was seized by half a dozen Frontiers who were waiting on the bank, but who, owing to the darkness, could not see what had been taking place while coming over. There was yet a mile to do before the town was reached, and stumbling and tripping, with our wet clothes clinging round us, that mile seemed like ten. At last the place was reached, but when we got near enongh, we found that nothing had been built, and that in fact there was no town.

This was the bitterest blow of all, and onr feelings can be better imagined than described. However, owing to the energy of the Frontiers and the carriers, whom no hardship or knocking abont ever seemed to dismay, a wretched mud half-built house, and two half-broken small barris were found, into which we crept, I occupying the former and Dr. Berkeley and the men nsing the other two.

It seemed as if the skies had opened their floodgates for 
the purpose of washing us out, for during the two following days and nights it poured incessantly. Our discomfort during that time and after what had passed can be rell imagined. This is one of the many "inconveniences" of travelling in West Africa. On the third day the rain ceased and the sun came forth, and we came from onr wretched shelters, and, strange to say, suffered no ill effects from the exposure and hardships of that never-to-be-forgotten adventure.

A great number of chiefs and others thronghout the Protectorate, finding that there was nothing to be gained by remaining against the Government, had surrendered unconditionally, handed over all arms, and retmined to their towns. A great number of arrests had also been taking place and the gaols in the different districts were filled with prisoners, the majority of whom were charged with murder. In order to allow for the trial of these prisoners a deputy-judge was sent ont from England, and the present Attorney-General, Mr. A. Hndson, accompanied the judge upon his cireuit through the Protectorate. A counsel for the defence of the accused was also sent out, and on the 1 th of October the judge and his party arrired at Sherbro, where at Bonthe the next day the Supreme Conrt was opened. In Sherbro alone, no less than nineteen prisoners were sentenced to death, all of whom had committed most atrocions deeds in the rising; other's were sentenced to penal servitnde for life.

The Court then proceeded to Bandajuma, at which place there were orer one hundred and twenty prisoners, where another sitting was held; the cnormons mass of evidence that was brought before the Court was of a most interesting though often of a horrible character. Some of the deeds that were committed by these people, a very few of which I have described, were almost beyond belief. Orer twenty of these wretehes were hanged at Bandajmma, inchuding several chiefs, among whom was Grubru, the Heard-Chief of Boompe, against whom there wils a string of charges, 
some of which were of a most gruesome character. Prior to the arrival of the Supreme Court at Sherbro and Bandajuma, sittings had taken place at Kwalu, the headquarters of the Ronietta District, at which place a large number of murderers were tried, convicted, and hanged. The measures thus taken by the Government in meting out justice to the offenders had a great effect among the chiefs and people throughont the interior. One of the effects of this stern retribution so rigoronsly carried out, was that although every man brought before the Court had as long and as fair a trial as it was possible to gire him, while he was defended by comsel specially sent for that purpose, several of the chiefs and people crossed into Liberia or remained in hiding.

Shortly after this a General Amnesty was proclaimed throughout the Protectorate.

Early in the following year, bodies of troops were organised and marched throngh the country. Even then resistance was met with, the natives attacking our columns from time to time. Fighting took place on the Liberian border on the eastern side of the Panguma District; but this was soon put down. The adoption by the Government of the show of force had good effect upon the country, as the natives saw for the first time large bodies of organised troops in every district thronghont the Hinterland. This Expedition terminated in April, 1899, and is known as the Protectorate Expedition.

Thus ended the operations in Sierra Leone. On the capture of the Chief Bai Bureh in the Timini comntry and the suppression of the rising in Mendiland terminated this most remarkable rising, and one of the most strenuous resistances to our arms that has ever taken place in our numerons expeditions in West Africa. 


\section{CHAPTER XTIII}

OUR POLITICAL ADMINISTRATION

"Equal and exact justice to all men, of whatever state or persuasion, religious or political; peace, commerce, and honest friendship with all nations."-JEFFERSOs.

THE enormons areas of comtry which have of recent years 1 been acquired by Great Britain in West Africa, and the heavy load of responsibility which their possession entails, nust render the question of the policy to be adopted in their future government one of paramount importance. We lave declared ourselves "Protector" orer the peoples inhabiting these vast tracts of comtry, and lave hoisted the "Jack"; and now that we have the land, what are we going to make of it? Is it to be a national exemplar of the talent buried in a napkin, or of the three turned quickly into ten by zeal and industry? Let us hope the latter. And there is good hope alead, for the beginning at least has been felicitons.

Already, despite the hostility which as pioneers of cirilisation we at first encomntered from the barbarous races who wander in the primevil forests of these comtries, we hive made steady progress, morally, materially, and industrially in our work. And nut only that; we have made this progress in the face of keen and jealons competition on the part of the other Power's, who had previunsly seized a goodly share of the 
country for themselves. We Britons were put upon our mettle to show what we could do in our capacity as the world's best colonists. Well, we "kept our end up." Today the term "British West Africa" stands for a territory boasting as successful an administration as that of any muder foreign government.

This success has been achieved in not one, but a variety of directions. It has been proved in ameliorating the social condition of the aborigines and in assisting them to develop the natural resources of the land; it has been manifested in the advancement of every kind of national industry and the improvement of erery sort of natural product; it has been evidenced in the marked increase of transport facilities by land and water; and it has been again exemplified by the opening up of rich and hitherto unknown hinterlands to the benefits and privileges of outside commerce. No bad record, surely, in the time. But we are in reality only just begimning. There is very much to be done in the future.

Besides, it has to be remembered that in successfully dealing with West Africa, as in progress generally, there is no finality. Of no place, at no time, can the words be written down, "Perfection has been reached; there is no more to be done." Sound as our methods of political and commercial government may appear to us now to be, they are still capable of improrement: some minor details have yet, no doubt, to be added in order that the executive machine may work to best advantage.

In attempting to carry ont that policy and those ideas, it was inevitable that some blunders shonld have been committed. Zeal will at times outrum discretion, eren in empire-building, and for our errors we have paid full dearly both in blood and treasure. But with sad experience came judgment. Quite early we decided that British rule in British West Africa was to be, so far at least as possible, "by the people, of the people, for the people." Great Britain 
was not to be a task mistress, whipping the natives to the corvée; but a faithful friend on whom they might lean, and a sound adviser on whom they might rely for counsel. And so, where we have been long enough established, the Native has come to believe in us and our disinterestedness in seeking his improvement.

To be sure, this has not all been bronght about at once, nor yet without occasional recourse to the argumentum ad puerum of the schools. The pupil was thick-headed, the teacher perhaps impatient: and when the former sulked the latter administered a salutary chastisement. But at length the scholar, grown much wiser by his stripes, found out that it was not good policy to kick against the pricks. And since he made that sapient discorery he and his preceptor have been the best of friends-as the years to come will surely show.

Certainly enormous strides have been made since the rising towards the improvement of the country, by establishing a more permanent and stable form of govermment, by opening up new trade routes in the interior. which shall tap regions hitherto practically unknown, and by the adoption of a friendly and conciliatory attitude towards the chiefs and tribal rulers.

The early treaties between the British Government and the native chiefs of the Sierra Leone Hinterland had always these three important objects in view, namely, to put a period to the internecine wars which had for so long decimated the populations of towns and villages, to promote legitimate trading by every possible means, and to prohibit and discomntenance the traffic in human flesh which formerly proceeded everywhere thronghout these countries. In this latter determination of ours lay the head and front of the grievance which the chiefs felt against the British; and this grievance it was which ultimately flared out into the rebellion whose course I have attempted to describe in the preceding pages. For centuries 
upon centuries the slave trade and this portion of West Africa have been inalienably comected. Human beings were regnlarly bartered and sold like so many head of cattle, and, shocking as it sounds to onr ears to-day, they were Europeans who primarily encomragel and participated in this nefarious merchandise. Even to this day many ontward and risible signs still remain in the Colony to tell of what went on in those old times. There are yet to be seen the rust-bitten cannon by means of which the Spanish and Portuguese "blackbirders" enforced their demands for live freights with which to fill their reeking holds; and down eren to the present time the dreaded word "Spanish" is able to strike terror into the hearts of the older inhabitants. The intervention of Great Britain in this direction has been thorough, if somewhat tardy, and if it is not yet entirely stopped in every district, the back of the slave-trade in Sierra Leone is broken, and as a remmerative industry it is, happily, ruined.

It is perhaps not a little strange, all things being considered, that the formation of the Protectorate of Sierra Leone was delayed to a date so late as 1896 . As already stated, disturbances amongst the tribes in the Hinterland had been of more or less freqnent occurrence since as far back as 1885, when the white inhabitants, including clergymen, merchants, and others, submitted a memorial to the then Governor pointing out that whilst the Coluny was entirely dependant for its maintenance upon the trade with the interior, yet from Rio Nunez on the north to the Mano River on the south the tribes were continually at war. The memorialists therefore urged the Govermment to bring abont peace at any cost, even, if necessary, by furce of arms. They pointed out that the slave trade, the root of all the trouble, was still being actively carried on under our very eyes; and proceeded to state that by the act of the Conference which had shortly before been held at Berlin, the necessity for assuring the authority of the great Powers in the territories 
occupied by them, for the purpose of promoting general freedom of trade and transit, had been quite fully recognised. And it is interesting to know that the preservation of the aboriginal tribes was a prime article in such Act.

One of the chief needs, if the recommendations embodied in this memorial for the protection of trade routes were to be carried out in their integrity, was an organised system of armed police-ing. An apt illustration of this need was exhibited by the fact that in the rery year in which this petition was presented the Yonnis had attacked and phundered Songa town; while two years later a place called Senehu, close to the border of the Colony, had been burnt to the ground and the male inhabitants killed, and the women and children carried into slavery. As a result the Government took action, and a punitive expedition, under the command of the late Sir Franeis De Winton, G.C.M.G., C.B., was sent up-country, which defeated them, and for a time put an end to the disturbance.

It will be seen from the foregoing that even in those early days the more enlightened inhabitants of the Colony were fully alive to the importance of opening up the rich Hinterland to down-country trade, and at the sime time to the desirability of putting an end to the iniquitous doings that were going on. But in order effectually to earry through the programme of remedial measures which had becn mapped out, a permanent territorial force was a sine qui non. The Frontier Police was therefore raised, whose advanced posts erossed the border of the Colony. The then Governor, Sir Samuel Rowe, was strongly in favour of this seheme, and his policy was given greater effect to by his successor, Sir James Shaw Hay, in 1889. A system of outposts and patrols was organised, and it was not long before the territories which had hitherto been drenched in bloodshed became tranquil and even prosperous, commercially. The new Foree was also able to exercise some eleck npon the kidnapping of slaves for sale 
in the interior to Nohammedans and others from the eastward.

So far so good; but in spite of their efforts there remained other districts which were still far from quiet; and I have already described the deplorable condition these were in at the time of Sir Frederic Cardew's tour through the conntry in 1894 .

But before the establishment of a Protectorate could become a fait accompli it was necessary that steps be taken to divide it up for administrative purposes. This having been done, the question now arose as to the source from which the expenditure for maintenance was to be drawn. A scheme was proposed by Sir Frederic Cardew, and this, with certain modifications, was accepted. The main proposition was that a House Tax of 10s. anmually for each native dwelling containing four or more rooms should be inposed, and one of $5 \mathrm{~s}$. for every smaller domicile. In the early part of 1896 it was decided that this tax should be leviable from 1898 upon the districts of Karene, Bandajuma, and Ronietta, its collection in the remaining districts-namely, Panguma and Koina-Dugnbeing postponed for a further period of two years.

The repeal of this Ordinance was subsequently brought about by the Secretary of State on the ground that certain of its provisions seemed to show that the lands of the Protectorate were vested in the Crown, which, of course, was not the case.

In 1897 a second Protectorate Orlinance was passed, the principal new provisions of which were, shortly, as follows :The establishment of three separate Courts of Jurisdiction, the first to be presided over by native chiefs alone, the second jointly by the native chiefs and a District Commissioner, and the third by the District Commissioner alone. The intention of this provision was the relegation to the chiefs of jurisdiction over civil cases arising exclusively 


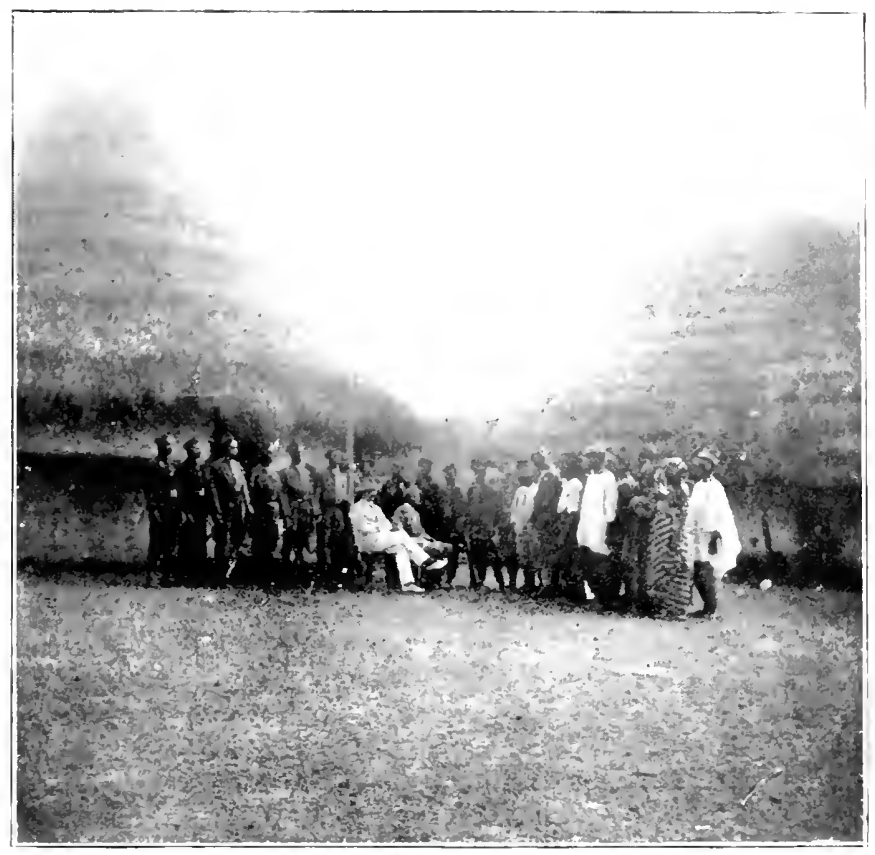

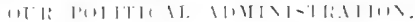

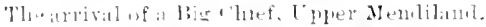

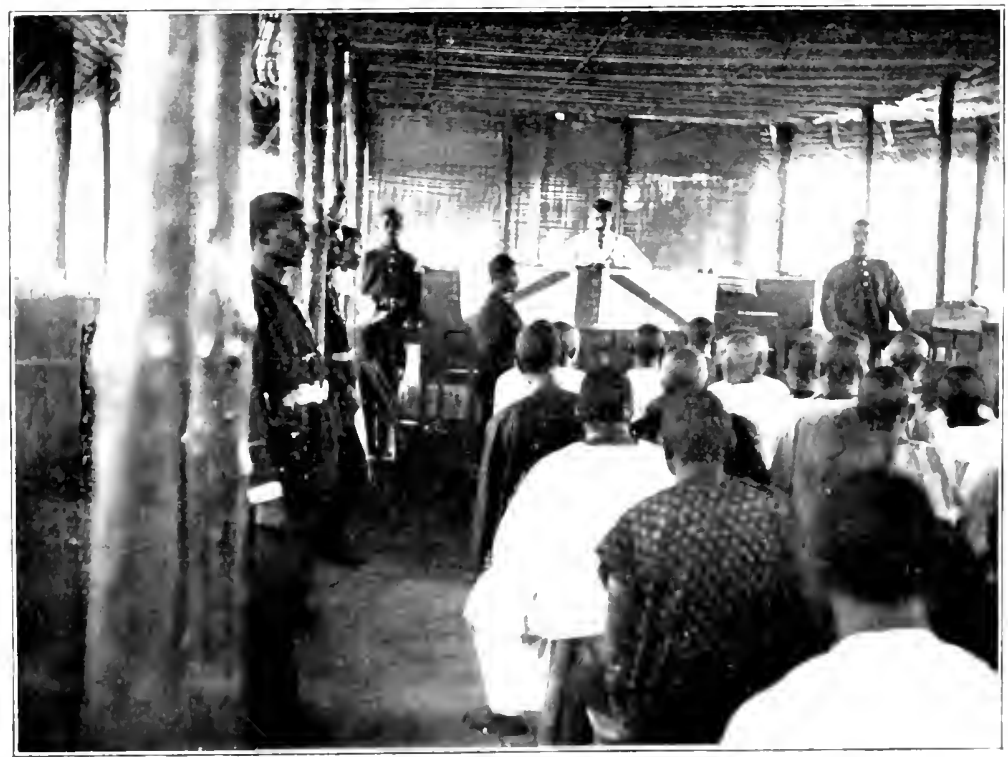

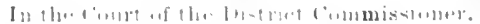



between natives, excepting such as involved questions of land title (the very ones they ought, one would have thought, to have had a voice in deciding). This native Court would also try criminal cases in which natives only were concerned, excepting those involving murder, homicide, and a few other offences of a serious nature, which would come before the second Court. In the third Court the Commissioner would take cases generally in which persons not natives were concerned, such as trafficking in slaves, and so forth.

The new Ordinance also enacted that as from the beginning of 1898 a House Tax of 10 s. should be levied for each native honse of four or more rooms, and $5 \mathrm{~s}$. for every house of three rooms or less, a commission at the rate of 5 per cent. being allowed to the chiefs, who were responsible for the collection of the tax, upon the full amount being paid.

The events which suceceded the imposition of the House Tax and the proclamation of the Protectorate Ordinance have been called locally "the Tax War"; and indeed some persons who knew little or nothing about the Hinterland and its people have gone so far as to aver that it was the tax alone which precipitated that outbreak. As a matter of fact, it was nothing of the kind. The war was not a "tax war" at all ; it was a "slave war." The chiefs saw the old order of things fast slipping away. The advent of a civil (and civilised) control by Europeans was imminent, an embargo would almost certainly be placed upon their barbarous customs and fetish ceremonies, and their principal source of wealth-namely, the slave traffic-would assuredly be done away with. They east about, therefore, for some pretext under which they could persuade the whole country to join them in a determined attempt to throw off the British yoke entirely. That excuse was now ready to their hand in the execrated "House Tax." The other grievances alrealy detailed were the gunpowder, laid a considerable time before 
in readiness for an explosion, the "House Tax" supplying the match with which to light it. That the rising was inevitable I have not the slightest doubt in my orm mind. Whatever had been the policy adopted by our Gorernment at that time, the natives who, it must be recollected, had never been made aware of the strength of Great Britain, and a large proportion of whom had never eren seen a white man, would monbtedly have risen and attempted to do what they dir.

Nevertheless, I say that ont of this evil much good has come. It seens, in fact, as if a cmitain had. since the late ontbreak, been pulled aside from before the people's eves so that now they regard the British from a different and much more rational point of riew. Sir Frederic Cardew, one of the ablest, strongest, and most conscientions Governors who has ever administered a British possescion, tonk infinite pains to find out as much as it was prssible to discorer about the little known Hinterland behind the Colony of Sierra Leone. As I have stated earlier, a distance of upwards of two thorsand miles altogether was trarersed, and mostly on fort, by His Excellency, and during his tours an enormons quantity of information, of great political and cthnological importance, was accumulated. His policy respeeting the imposition of a House Tax on the natives, as well as the provisions generally of the Protectorate Ordinance which he drafted, was quite sound; and that it was so the fact that this policy to a great extent is being carried out to-day, and with every success, abundantly goes to show.

We came into this land with an inadequate staff for the work before us: just a handful of British officers seattered over a country abont the size of Ireland, and inhabited by a savage and disaffected population. But the herculean task with which the Colonial Government found itself confronted has been magnificently performed; and anybody present, as I was, in the comntry at the berinning of the trouble and 
returning to it later, conld not fail to be surprised at and struck, no less with the great strides made towards material progress than with the cordial relations which subsist to-day between ourselves and the natives formerly so hostile to our rule. The change that has been brought about in that short space of time is a revelation certainly, and one that will afford very pleasant writing in the future for historians.

We appear to have recognised at length the fact that the only way successfully to govern our West African Protectorates, inhabited, as a number of them are, by a population just emerging from a state of savagery, and whose ideas and notions are entirely different from our own, is to rule through the people themselies. The African is by far the most valuable asset that Africa possesses, and throngh him and by him only ean the best results ever be obtained. Let the kings, chiefs, emirs, and others in anthority, retain the same executive powers that they had before the advent of the British regime, and, if possible, even greater powers than then. Let their laws and tribal customs, which have been carried out in the country for untold generations, be interfered with as little as possible, excepting, of course, so far as these rum counter to the practice of cirilised nations. Let us respect even their religion, especially when the people are followers of Islam. Do not let on missionaries, well-intentioned and good men as they no doubt are, come here and thrust another creed, even if it is a more exalted one than their own, upon the natives molens rolens.

The Christian missionaries have, there is no sort of doubt, a grand and noble work before them in the future here. But they ought to see that the only way in which the moral nature of the Afriean ean be improved and enlightened is through the children. It is, I think, almost a physical impossibility to influenee morally the mint of an adult up-comntry aborigine and change his irteas, and I fear that a large amount of wasted labour and uscless time has been spent by the missionaries in 
attempting to do so in the past. But through the rising generation of young Africans something may and will, I doubt not, be accomplished. Let them be taught a useful trade or handicraft. But let it be understood that before any lad can become, say, a good carpenter, he must be educated. Let him be "canght young," in fact, and let liis education include a good technical training also. In that way rery much may be done with him, and I understand is being done at present. Noreover, always hitherto the missionaries seem to have begun to whittle away at the wrong end of the stick. If proselytising is to be done effectirely among the tribes it should be delared until they have learnt to respect ns, and to feel that in ourselves they hare strong and faithful friends, and that without us their material condition would be many times worse than it is at present. These feelings should first, I say, he fostered and encomraged, and then it will be time enough to think of introducing into their minds the ideas and creeds of Europe.

I have said that Africa must be worked by the African. It is most necessary that this fact should be always bome in mind in all questions relating to our administration and derelopment of this part of the Continent. Sierra Leone has, there is no doubt, a brilliant future ahead of it. The chiefs are already beginning to realise and appreciate the benefits which have accrued to them since we first came into their country. To-day we find the people happy and contented. The crops are to be seen growing everywhere; there are no stockades around the towns and rillages; everybody can walk where he likes, and trade generally is in a flourishing condition. Moreorer, they hare at last begun to realise that in order to secure the benefits they are receiring a small tax has to be paid for the upkeep or the Government which bestows them. Whenerer we look back upon the old days we find that it was useless for the people to plant their crops because, as they themselres 
would say, "they never knew whether they would be there to eat them."

As I have remarked elsewhere, I was struck on my return to Sierra Leone in 1902 with the immense strides that the Protectorate had made during my absence from the country. The present Governor, Sir C. A. King-Harman, K.C.M.G., is very popnlar, not only with the inhabitants of Sierra Leone itself, but with many of the chiefs and people in the interior with whom he has come in contact. Ho has made himself personally aequainted with the conditions of the Hinterland by undertaking lengthy tours throughout every district, and during these jomrneys has been brought into direct tonch with the chiefs and people, and has thus had an opportunity of making himself aware of their grievances and desires. In this way a considerable amount of information has been obtained which it is so necessary that the head of the Government shonld know.

The last joumey His Excellency made was to the Bandajuma District, and lasted from the 20th of Jamuary until the 20th of the following month. During that time nearly the whole of the circumference of this district was traversed. I accompanied the Governor on this occasion as Commissioner, and large meetings, attended by the chiefs and people, were convened at every important town and village through which we passed.

At nearly every town at which we stopped the Govemor convened assemblies of the chiefs and people and invited all to come forward and say what they had in their minds, either conecrning the House 'Tax or the Govermment. It speaks volumes as to the great strides that have of late years been made towards establishing an entente cordiale botween the natives and the British that at these meetings there were practically no complaints of any importance made. Many of the Paramount Chiefis in the presence of their people openly told the Governor that they satw and understood now how quict 
the country was, how they were able to keep their farms, and how every one of them was safe. They declared that they appreciated the protection the Government was giving them, and that they did not object to contributing their share by the payment of a House Tax towards its up-keep. I think in nearly every meeting that took place, these sentiments were expressed, whilst the complaints made were for the most part trivial, and such as could be settled on the spot.

From an intimate knowledge of these people, I am assured that the House Tax is not felt by them, and so long as fraud is prevented in its collection, it can very easily be paid. The slave question is a much more difficult one, and needs most careful handling by the Government. One of the real grievances of the chiefs and other important people in the country (known locally as "the big men") is that their former domestic slaves are leaving them, and that they have no one to work their farms and look after their homes as before. The domestic slaves of the chiefs are really not slaves as the word is understood at home. A man becomes the servant of the chief either by inheritance, by choice, or by purchase. He has to do a certain amount of work for his master, and in return receives protection, wives, and is even sometimes given property. The work these domesties have to do is by no means hard or unpleasant. As a rule a slave will work for five days in the week for his master, and for the remaining two days he can work a farm of his own which his master has given him. I have known cases where a "slave" has run away from his master, gone to Sierra Leone, and finding the outside world too hard for him, has, of his own free will, returned to his former employer and home. These men who have left their masters in the interior and come down to the coast towns have to work a great deal harder for a livelihood than they did in the bush. Even now a number of these so-called slaves are beginning to recognise this, and we should give the Chiefs every assistance to keep their "boys" from leaving them, for 
in its present state the wealth of the Protectorate can only be developed and the country ean only be properly administered through its inhabitants, and, of course, without labour no adrancement whatever can be made. Properly handled by the Government this domestic slave question will be no trouble, and one of the great and genuine grievances of the land and property owmers in the Protectorate will be removed. We have a splendid country here, and one small enough to be easily tapped, but to derelop it effectively we nust nuake it worth the African's while to join handsomely in this profitable unclertaking.

Moreover, in a country of this kind, it is of the utmost importance that the right officers are obtained for administrative purposes in the Hinterland. The proper qualifications are by no means easy to find; and a man unsuited for his position, no matter what his qualifications may be, can do an incalculable amount of mischief. I think the man who will be really successful in this kind of work, is, as a rule, one who takes real interest in the work for its own sake, and not merely as a perfunctory performance of his duty. He should be openminded, firm, patient, tactful, and have courtesy and consideration for others. As I have before remarked, good health is, of course, a sine quâ non, for withont it a man cannot possibly really do his duty. He should also endeavour to make himself acquainted with the language of the people amongst whom he resides. Being dependent on an often unserupulous interpreter has sometimes, within my certain linowledge, resulted in miscarriage of justice, and in Court, where the answers to questions depend in law so much upon the way they are given, a great deal must be lost. An officer who possesses these qualifications can do almost anything with his people. The Chiefs will respect and trust him, and will seek his adrice. And his moral suasion will be so great that the advancement and development of the comtry through its people will be assured. 
As I have previously remarked, the Colonial Government and its officers have had great difficulties to contend with; but these difficulties are gradually but surely being overcome. For in these vast and wild areas every man who has done his day's work honestly has left his mark upon the land, and done his share in binding together those great strands of Empire which traverse all latitudes and longitudes and mite the most various races and colours in a common devotion to King and Country.

I have previously remarked that the power of the Chiefs must be upheld and receive the support of the Government, but in doing this we must not lose sight of the rights of the more humble native. British anthority in the West African Protectorates is upheld usnally by an abnormally small staff, whose jurisdiction extends over large areas of country. The instrument by which our ordinances and laws are upheld is the aid of locally raised natives, who join onr service as police, Court messengers, soldiers, etc. A native with the smallest vestige of power will invariably abuse it on the first opportunity, and there is little doubt that our subordinate officials have, times without nmmber, abused their position and, taking advantage of their uniform, have far exceeded their power as police, or whatever they may have been. And I believe that in the early days of the Sierra Leone Protectorate the Government and even the Emropean officers were wrongly blamed by the inhabitants for the behaviour of their native subordinates, whether travelling or stationary in different parts of the country on duty. This state of aflairs is being gradually reformed by rigorously punishing the offenders when caught. The African, in his native state, is, as a rule, very slow to make a complaint against any one wearing the Government uniform, and when he complains there is usually good ground for his doing so. As a rule, even when his complaints are gennine, he has little encouragement to make them, for he may be many miles from anyone in authority, while the offending ofticials might in some 


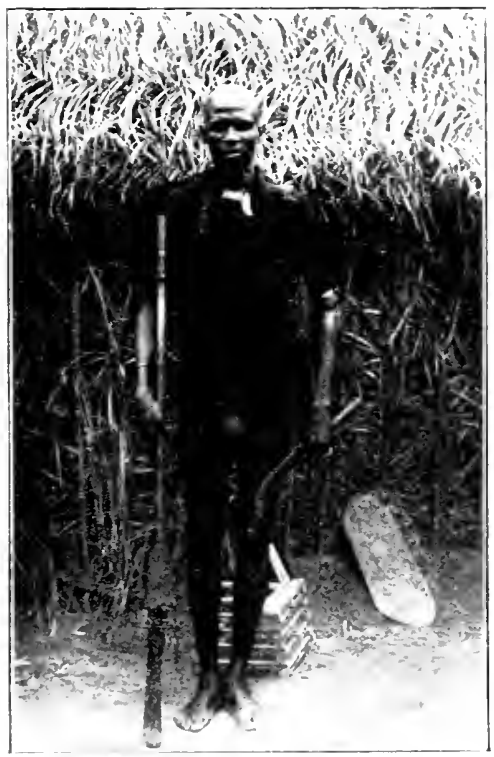

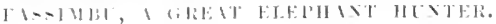

P. 19:,

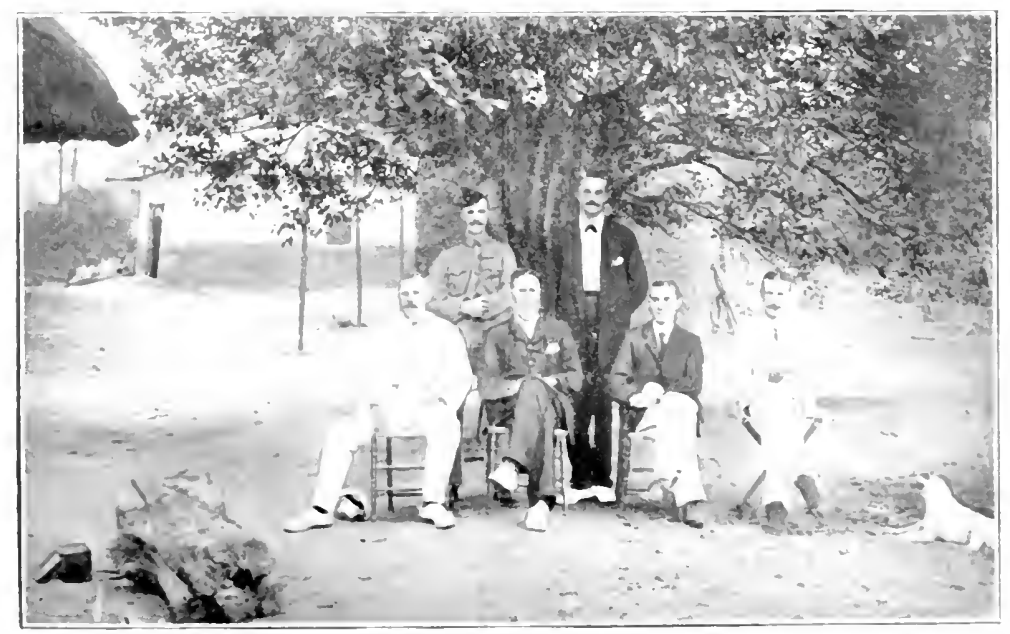

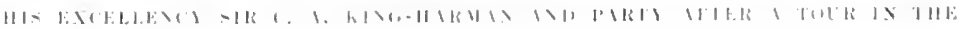

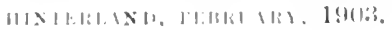

Jo fuce p. 211. 

way or other be able to make the situation worse for the complainant before he had time to reach the Government headquarters.

To summarise generally, the advancement of the Sierra Leone Protectorate since the lamentable occurrences of 1898, affords a wonderful example of what courage, firmmess, tact, and hard work can together accomplish in a comtry as savage and as little known as this was only a few short years ago. 


\title{
CHAPTER XIX
}

\author{
OUR COMMERCIAL POLICY
}

"The worl: under our labour grows Luxurious by restraint."

Milton.

THE question has often been asked by persons interested 1 directly or indirectly in the commercial expansion of the Empire, what are the prospects in future for the development, on trading lines, of our possessions and protectorates in West Africa? Snclı an interrogative has, in varions forms, been put to me personally, not once, but many and many a time, and my answer has invariably been that the prospects or, at all events, the potentialities, are practically unbounded, whether commercially, politically, or hygienically regarded. Certainly the strides made in the past few years towards developing our national estates on the West Coast upon sound business lines have been enormons; and there is every indication that even this rate of progress will be exceeded in the near future. But a very few years ago the shipping lines running between Great Britain and this part of the African coast were but few and far between. But Supply created Demand; and the rapid expansion of industry has necessitated the multiplication of oversea transport facilities, and to-day not one but sereral fine lines of cargo-steamers ply regularly at short intervals between the West Coast and Liverpool and Plymouth.

So far, so good. A big task still remains, however, to be 216 
performed by the British Government and by British merchants, if they would grapple successfully with this huge question. The greater part of West Africa is beyond all doubt magnificently rich in a variety of indigenous products of a value that can scarcely be over-estimated. But-and the "but" is a big one-it is yet a new conntry, a land of To-morrow. There is one thing still needed, if the natural wealth with which the country teems is to be tumed to good account-I mean, of course, the construction of rail and waterways. Upon the "metals" a major portion of the prosperity of the future of the conntry hinges; and until they are laid down no real and substantial progress can be recorded. Again, in the vast tracts of Northern Nigeria which we have lately acquired-surrounded as they are by the big Hausa States with a population rumning into several millions, with whom, as with many other of the native races, a flourishing trade has for years past been carried on-lies one of the most important markets of the world. Having, I say, recently obtained the right to "protect" this huge slice of virgin territory we have here, if only we ntilise it in the right way, an illimitable source of wealth all ready to our liand. Here is a comntry one-third the size of India, inhabited by peoples many of whom are considerably above the ordinary negro standard in intelligence, but which at present, so firr as we are concerned, remains entirely unexploited, and, as regards a large portion of it, absolutely unknomn.

To the south of it lies Sonthcm Nigcria, a great region whose plysical characteristics are altogether different. This is, par excellence, a timber country; a land of dense forest and thick unbroken "bush." Here flourish in a very riot of profusion all, or nearly all, the most valuable sorts of timber known to western commeree, as well as many other kinds as yet unknown to us. Through it flows the mighty Niger, and the earth on either side of it literally tcems with rich natural products, both above grome and below. 
Then there is the Gold Coast. The whole of this wide country, with its vast interior, by which I mean, of course, the Northern Territories, is, no doubt, capable of immense and profitable development.

But leaving these great outlying countries for the present on one side, let me confine myself to the one with which I have been more immediately and personally concerned, namely, Sierra Leone and its Hinterland.

I have said that the future which lies before this comntry is, economically speaking, very full of promise. The only desideratum is that railway communication should be established between the Hinterland and the coast, and the fertile tracts of the interior thereby brought into direct touch with the metropolis of Northern England-Liverpool. I am glad to be able to add that our Colonial Govermment has shown itself alive to this necessity, and a railway is even now being rapidly pushed into the interior. That lime will open to outside trade leagnes and leagnes of territory hitherto unprofitable only because, owing to the upper waterways being unnavigable even to light-dranght craft, the chiefs have been unable to get local prodnce down to market on the coast in any paying quantities.

For years uncounted the palms have dropped their nuts on to the ground only to rot there, for the reason that there was nobody to take them anay, The narrow-gange railway will alter all that, and the chiefs of those inland nations will at length have an opportunity afforded them of estimating for themselves the benefits to accrue from the development of their lands. They will readily see, if they are alive to their own interests, that it is far more profitable to send down the large amount of produce which they have in their hands, and for which they can obtain good prices at the coast, than to ruin their people and depopulate the country by slave trading and petty wars, as formerly. Not only will the increased quantity of palm-nuts gathered yield a splendid return under the new conditions to be inaugurated, but there is a further and con- 


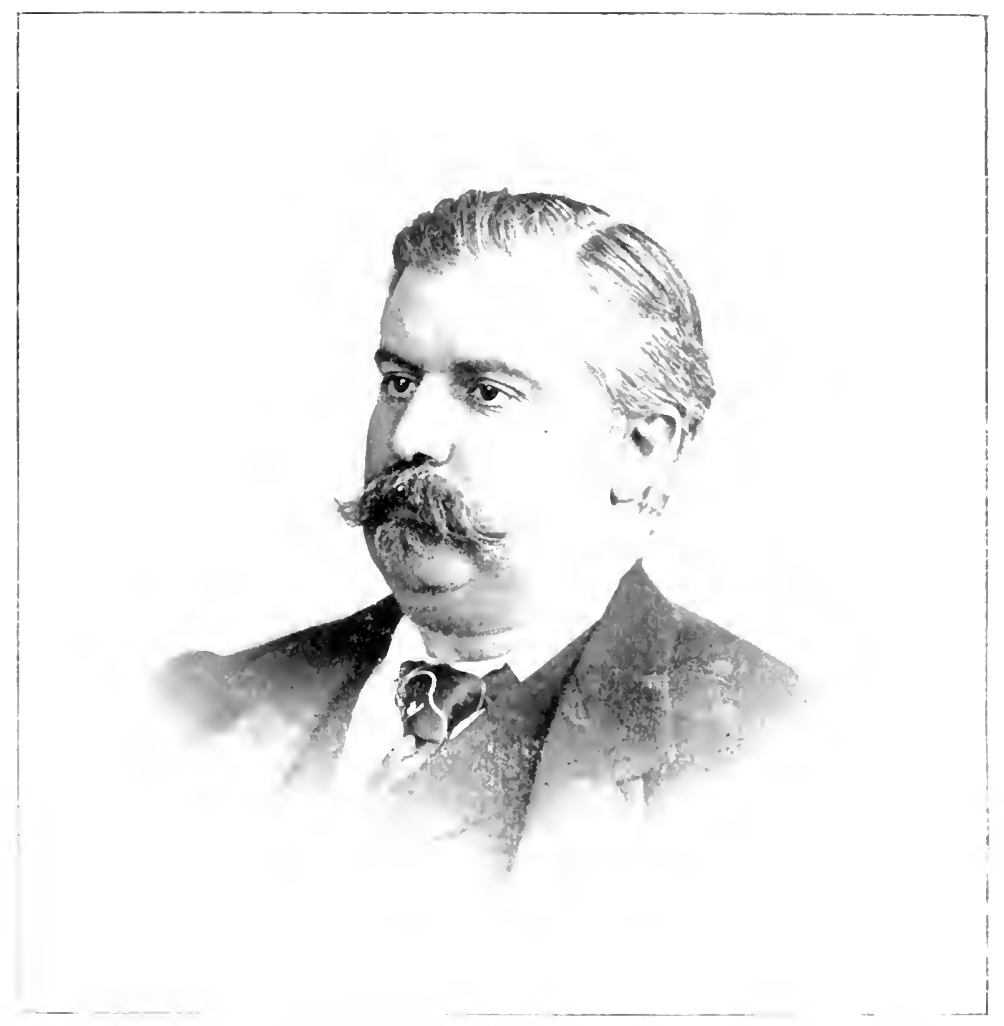

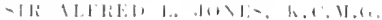

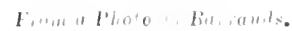



siderable advantage to be derived from the oil in which the kernels are so rich. And in this connection I must not fail to record the important service rendered to commerce by the employment lately of a more scientific method of cracking than formerly obtained. Previously, one great dramback to the profitable character of this industry lay in the diffieulty experienced in cracking the nuts and separating the kernels from the shells. This used to be done with the aid of stones by the women, who spent the greater portion of their days engaged in this laborious and monotonous occupation. I had, some little time ago, an opportmnity afforded me of watching the working of a couple of the ingenious machines which have been devised to supersede the old way of doing things; and I can truthfully say, after a somewhat exhaustive inspection of their performance, that the eare and rapidity with which they did their work came as something in the nature of a revelation to me. Once these machines come into general request, as there is little doubt they will so soon as the slow-moving mind of the black has understood the immense saving of labour which their use involves, and the enomously increased amount of produce which can be dealt with in a given time, and the palm-kermel trade will receive a fillip such as it nerer previously knew. To sum up on this head, I look upon the West African palm-tree as constituting one of the chief, if not the chief, sources of the comutry's wealth. Just as Mohammed told the Arabs to "cherish the date-tree, for she is your mother," so I advise the native here to do the same by the nut-bearing palm, of which indeed there is no part which cannot be turned to profitable account.

I have referred to the palm forests of the interior as supplying an inexhaustible source of wealth. But these are not its only assets by any means. The finest rice, probably, in the world is grown in the Hinterland of Sierra Leone. I to not, I confess, think that West African rice is erer likely to be in rery great demand in the markets of cireat Brituin. For 
we British are a peculiar and a remarkably conservative people in certain matters. We see the small white rice of India put ont for sale, and alongside of it the West African grain, which, thongh coarser and dirtier in appearance, contains quite three or four times the amount of nourishment and gluten. It is almost a foregone conclusion that British customers will be taken with the Indian sample, as looking so much finer, while the West African, which is so much better than it looks, will remain unsold.

But if that be so, the continent of Africa still remains to the grower from which to reap a fortune. There is a continual and ever-increasing demand for the commodity, both in our own possessions and in the great countries lying to the north and south of these. That demand it may well be our ambition to satisfy. Here we have some millions of acres of land only waiting cultivation, with customers practically on the spot. What an enormous field of enterprise is open to the native here! Is he going, with our assistance, to avail himself of it?

Great interest has, again, been taken recently by Great Britain, Germany, and other countries on the continent, in the derelopment of the cotton industry in West Africa. Already, the Germans have had most successful results from their experimental cultivation of the cotton plant in Togoland; and now the governors of our own West African colonies are bestirring themselves to push matters forward in the same direction in the countries which they administer. Sierra Leone has not been behindhand in the effort to induce the native chiefs and the up-country traders and farmers to take up this industry in earnest. If they do so, then there is little doubt of a successful issue, though careful nursing will be necessary for some little time to come. Meanwhile, the colony has started in the right way by engaging the services of skilled cotton experts to go ont and show the people, and others interested, the best way to set about planting the seed. 
This, mark you, should be home-grown, and not a foreign kind. The latter would never be able to stand the heavy deluges of rain, but would be washed ont of the ground and destroyed directly. The local cotton-seed is of quite good quality and much better alapted, besides, to the country requirements and conditions. At present this cotton is, like the country itself, in a wild state, though freely employed by the natives. Yet the result is sufficiently good to show what may be achieved by systematic culture. All that needs to be done is, as I have said, to place this seed, which is part and parcel of the country's natural produce, moner proper enltivation. We must grow it over extended and carefully selectcd areas; and before everything else we must not mind whatever trouble and labour it may cost to encourage and instruct the natives in its growth, until at length West African cotton has obtained a good hold on the country and a firm footing in the markets of Great Britain.

This is quite a feasible project. The soil is there, the climate is there, and the transport facilities will be there directly. In very self-defence, and for the sake of our preeminence as a nation of traders, we must not allow the other countries to step in before us here. Nor, with the exereise of energetic and prompt measures, is there any reason why they should. I am glad to be able, too, to testify to the indefatigable pains which the present Governor of the Colony has been at, both during the time he was last in England and since his return to the seat of government, to foster and encourage the development of this magnificent industry. His efforts have been well supported by many of our greatest merchants and business men at lome, and notably by Sir Alfred Jones, K.C.M.G., the head of the great shipping firm of Elder, Dempster, and Co., who has, with praiseworthy public spirit, granted unusual facilities for placing the early yield of native crops upon the English market.

It is scarecly necessary for me to labour the point of what 
the cultivation of a fully adequate cotton crop in West Africa would mean, from the political standpoint, to this country. Every good Imperialist will readily realise the advantage it would be to Great Britain were she to succeed in producing, in her orm African colonies, snfficient cotton for her home requirements, and thus become altogether independent of American supplies. There is not the slightest reason, either, why she should not achieve this olject, nor why, before so rery many years are passed, the big cotton-spinning and wearing mills of Lancashire should not be fed entirely from an article grown within the boundaries of a self-sufficing British Empire.

And if this grand comntry is to be thoronginly and systematically tapped, one thing before all else is a desideratum, namely, the fact that we must arail ourselves to the fullest extent of native labour. And herein arises another difficulty -not an insurmountable one, but one which will still have to be grappled with and overcome before any real progress is made. The raw material abounds all orer the country. But it las to be said that your. West African native, like other persons whose lives are passed mider the enervating influence of a tropical sun, has a routed disinclination to the doing of more manual work than will suffice to keep him in the rude necessaries of life. His wants are for the day only. "Tomorrow" is a word without much meaning for his mndeveloped intelligence. The industrial development of the Negro is the first thing, then, to be taken in hand. Give him to understand that a little more labour on his part will result in a very material increase to his own comfort and well-being, and he will begin to take quite kindly to paid work.

And there is a right and a wrong way of going about this. To attempt to get at the African aborigine direct would inevitably be to court failure. He must be approached through his own chiefs if anything is to be got out of him at all, and we shall have only ourselves to blame if we try 


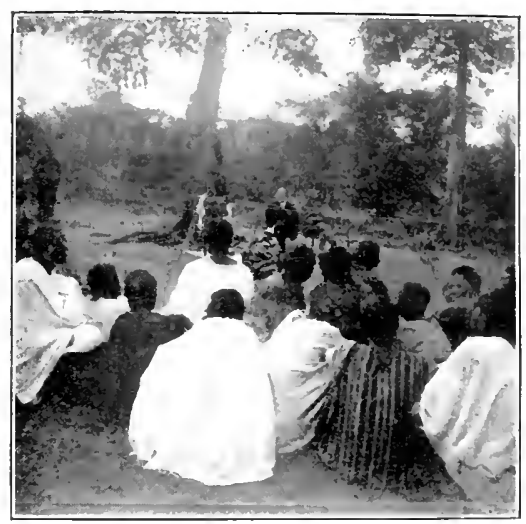

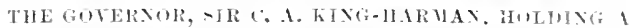
MEETIXं TX THE HITERLIVH.

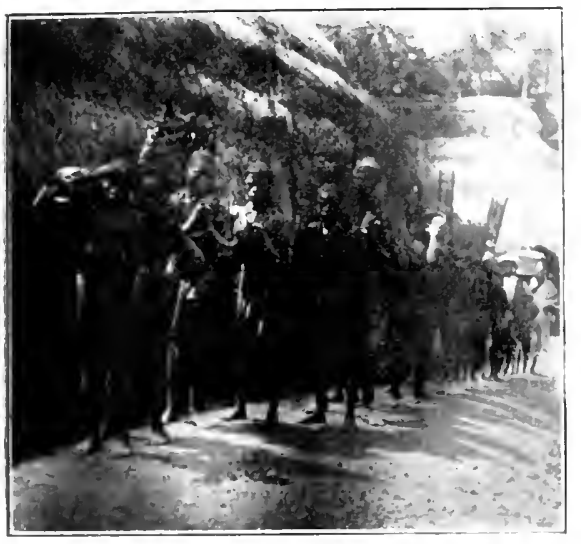

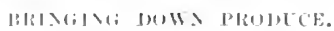

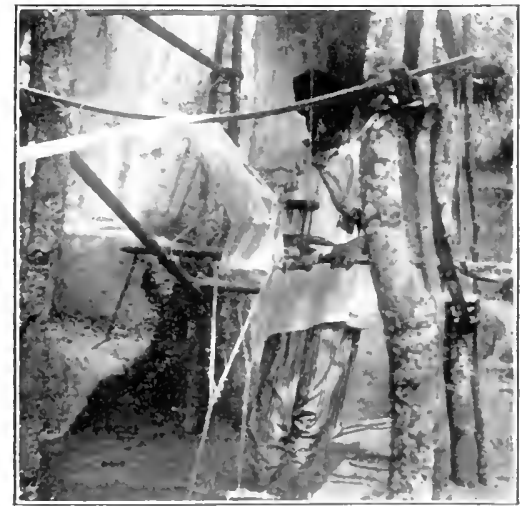

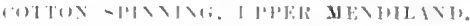



any other method. It becomes our bounden duty, therefore, to encourage and support in every legitimate way the authority of the local heads of tribes and villages, and to give them such assistance as white men may in keeping their people mell in hand.

My orn experience has been-and I have traselled somewhat extensively in this part of the country-that the native "boy," once he ean be set going, is both a willing and a cheerful worker, provided, of course, that he is fairly well treated and has the assurance of receiring some kind of fair remuneration for his toil. Moreover, I have found the chiefs, as a rule, only too willing to assist in procuring an adequate supply of labourers, thongh they naturally expect, and are entitled, to receive some small present, either in cash or kind, for using their influence on our behalf.

The labour question, then, coming as it does under the heading of "profitable employment for the inhabitants," is one of supreme and paramount importance in the development of West Africa. There are, of course, scores of channels in which this labour may be adrantageously made use of ; whilst, deprived of it, the land must languish, as it has languished for uncounted centuries in the past, and the people who inhalit it must remain in a state of barbarism.

Resuming the tale of the land and its assets, commereially speaking, mention should be made of the rery excellent native-woven cloth. Despite primitive appliances, the manufacture is really first-rate; the cotton-woven elotlis of the Sierra Leone Hinterland-and especially those whieh come from the hand-looms of Mendiland-being, if somewhat coarse in texture, practically indestructible in the matter of durability and wear, as well as exceedingly tastefinl in colour and design.

I am not aware that particular eneouragement has ever been extended to the natives to weave their eloths in greater quantities. That, I think, is a pity, for here we liare so 
much industry, and, I might add, talent, running to seed simply for want of an incentive to display itself. If only a regular market conld be established to which these valuable prodncts could be brought, and where a fair tariff price could always be obtained for them, I am quite satisfied that the result wonld be of incalculable benefit to the people and chiefs alike, whilst as a civilising influence it could scarcely be surpassed. Even the missionaries will be with me, I imagine, when I snggest that one of the first steps towards improving the moral status of the West Coast negro is to get him to wear some kind of clothes, however light, and to take a pride in wearing them.

Another very valuable product of this part of the coast is rubber. In this certain portions of the Sierra Leone Protectorate are particnlarly rich, and I have myself passed, on several of my journeys in the interior, throngh immense forests of rubber trees, only waiting to be tapped to yield up their precious stores of sap. At present this industry, which might, and ought, to become one of the most important staples of the Coast trade, is practically non-existent, owing to the lack of sufficient enterprise on the part of the chiefs to get it on the market. Here and there the trees are " milked," to be sure, but in the unscientific and utterly wasteful manner in which the native does everything when left to his own devices. All this might easily be altered. A thorough examination should be made of the rubber forests; the trees should be tallied and divided into groups for systematic tapping, and speedy means arranged for getting their yield down-country. I am of opinion that the trouble involved in doing all this would speedily and amply recoup those who took it. The rubber of no conntry in the tropics is of better quality, intrinsically, than that grown in this part of West Africa, and in point of cheapness of production the rubber of Mendiland would be found to compare, I think, quite favourably with any other growths whatever elsewhere. 
A once important local industry, but one that has of recent years fallen for some inexplicable reason into desuetude, is coffee cultivation. On one of my visits to England I bronght home a sample of coffee berries from the Mendi country; and it was very much appreciated and liked. Indeed, I believe that the coffee grown in this Hinterland is at least as fine in quality and flavour as any that the world produces, not even excepting Mocha itself. From the local merchants at Sierra Leone this coffee, which is absolutely pure and free from any kind of adulteration, can be obtained at the price of $6 \mathrm{~d}$. per lb. at any time, and, indeed, I believe the usual price in the local markets is something like $4 \mathrm{~d}$., with a fall, recently, to a figure eren lower still. Now it would be a thousand pities were this excellent article to be permitted, for want of a little attention, to go entirely out of cultivation; and of the many openings for trade which this part of the coast affords few have a better chance and a brighter future before them, in my judgment, than the enltivation of the coffee bush.

It is by giving our attention to these minor products, so to say, of the land that we can best help to awaken in the aborigines that interest in their own advancement and intellectual progress which is so necessary a prelude to their turning an inquiring mind to a consideration of more important questions still. 


\section{CHAPTER XX}

\section{otr COMAERCIL POLICY (continued)}

THE foregoing remarks on the commercial position of the 1 Sierra Leone Protectorate would be incomplete without a reference to the cultivation of fruit, for which nature has so eminently fitted it. Here, in the multifarious regetable products which spring up almost spontaneously in its rich and fertile soil, lies another opening for profitable trade. Than the Coast and its Hinterland there are probably no better fruit-growing countries in the world, and certainly nome boasting a wider range of products. Mark you ! the majority of these are at present in a semi-wild state only. The best known, perhaps, because it is the commonest, is the banana, which occupies in West Africa a position analogous to that filled by the commonest of our English fruits at home. Now the banana has, erer since its introduction, been a most popular fruit with us in this country, where a tolerably good price is still paid for it. At present the chief source-or one of them, for we have now to reckon with Jamaica-of our banana supply is the Canary Islands. Fet the banana of Sierra Leone is of infinitely better quality. I minderstand, moreorer, that in the Canaries the cost of cultivating this fruit for the English market is still comparatively high. In Sierra Leone and the comntry at the back of it the cost would be practically nothing at all. That being so, and since the banana is met with in nearly every town and village throughout 
the Protectorate, it is not a little curious that its growth for export purposes does not at any time seem to have been serionsly considered.

The cause here, as elsewhere, is, of course, to be found in the lack of transport facilities betwixt that comntry and this. Given a service of fast steamers plying regularly between Liverpool and Sierra Leone, and an immense trade ought to be inaugurated in the banana and other fruits. The proprietors of the Elder-Dempster Line have done a great deal for Jamaica in starting a fleet of "fruiters" to run between Kingston and Milford Haren. Would it not, I ask, pay that enterprising firm to do the same by the African West Coast? Certainly cargoes would never be lacking, whilst in point of size and flavour the African article compares quite favourably with anything grown in the West Indies?

Then there is the pineapple-another fruit whose natural home would certainly seem to be the moist, warm jungles and field-patches of this country. During my travels in the interior I have everywhere seen the pinc growing wild in profusion. I have also grown them in my own garden with excellent results, and my table was seldom without a handsome specinen upon it. I do not know what the exact cost of this fruit is in England: something considerable, I understand. In Sierra Lcone they are worth from a halfpemny to twopence each, and even the higher sum is not exorbitant having regard to the size of the fruit that is obtained. Here again, then, is a fine field waiting to be tilled. Would it not even be worth the while of some enterprising firm to start a "canning" factory on the Coast in which these delicious and wholesome fruits contd be sealed up by the thousand and transported to this country?

Amongst other indigenons fruits of sorts is the mango, which flourishes à mereille all over the country. I have seen in many an upland town the trees literally groaning beneath the weight of fruit that alnost smashed their bending 
boughs. While they are found almost everywherc the mangoes of Sherbro district enjoy a special reputation for the delicacy of their flavour. Although I have no idea as to what they fetch at present at home there should be no difficulty about their transport in any quantity to Europe.

But, as I began by saying, the whole eomntry from one end to the other literally teems with fruit and garden produce; amongst these being paupaus, oranges, both sweet and bitter, limes, guaras, plums, alligator pears (a thick-skimmed fruit more closely allied to the regetable tribe), granadilloes, tomatoes, sweet potatoes, yams, "jakatoos" (a kind of green tomato), pumplins, ground-nuts, and so on ad infinitum.

On looking over my notes in this comnection ? find that I have omitted to give honourable mention to the cocoa-nut. The cocoa-nut palm grows anywhere aloug the eoast and within a radins of about fifty miles inland, beyond which limit it is not often met with. Along the whole coast-line of Turner's Peninsula there are miles upon miles of ground most admirably adapted for its cultivation. Yet little or nothing has been done in this way beyond what the natives may require for their own consumption. The pity is the greater since this palm is one of the most useful of its kind in existence, not evell excepting the bamboo. From it is obtained, amongst other products, copra, a marketable article which I should like to see gaining much ground in the near future. Here is an industry in which little labour or initial cost would be entailed to give most remmerative results. As I have said, there are miles on miles of ground lying close to the sea covered with the sandy soil that is so admirably suited and necessary to the growth of this prolific tree. Now, one acre of cocoa-nut palm should produce a ton of copra. A ton of copra is valued at $£ 15$. Therefore every acre under cocoamuts is worth $£ 15$ for the fibre alone, irrespective of oil, and so on. When this is remembered it is easy to see what an enormous profit awaits any one enterprising enough to give it a trial. 
Before concluding my remarks upon commercial matters I propose to say a few words on the currency question, as that affects to-day this portion of West Africa.

Ever since the imposition of the Honse Tax minted coin has circulated freely in the interior, and the people are at length beginning to appreciate its superiority as a medium of exchange to the old-time system of barter in lind.

As illustrative of this fact I may appropriately reeall an incident which occurred when I was travelling in the interior in 1899. During the Protectorate Expedition in that year I had occasion to pay the chief of the Dama country for rice supplied to the troops. The amount was something rather considerable from the native point of view - that is to say, it would run into a sum of between three and five pounds sterling. When I offered to pay for the rice the chicf remarked that he did not want money, but would prefer to receive the amount in tobacco, eloth, and sunff. With this request I was mable to comply, and I proceeded to connt out the money in silver, which I handed over to him. Some time later I again met this chief, who told me that he was glad he had made up his mind to take the money as he had had it melted down into bangles and other ornaments for his numerous wives. I may add that in 1902 this same chief collected a sum of $\$ 680$ in cash from the inhabitants of his country as their contribution to the House Tax, which he duly brought to me, when the amount was deposited and passed to account in the Colonial Treasury in the usual way. The ehiefs highly appreciated the commission which they received according to regulation for the collection of the tax. In fact, the preference for money over "kind" is now becoming general over the whole country, although there are still districts, the people of which prefer to receive their fees in tobaceo, etc.

So smart in money matters lave many of these people become that it is almost impossible for a white man to get to 
windward of them in a trade transaction. I recollect once offering a Susu trader a coin which I thought for the moment was an English shilling. He took it, tumed it round, and carefully studied it for the space of a couple of minutes. Then he handed it back to me with these words, "Massa, this money no good ; this not nah Queen's head," and I had to take it back and give lim another one instead.

In the north-east corner of this Protectorate, country iron constitutes the currency, and here a well-to-do person may with no sacrifice of truth be termed a "man of metal." The iron coinage in this case consists of long strips, one extremity of which has a narrow "twist" with a small handle in the shape of a "T," and bored at the top. A piece of this iron is worth, roughly, from $1 \frac{1}{2} \pi$. to $2 \pi$. But the two commodities at present in most frequent demand in the interior are salt and gunpowder, and to obtain these the natives will almost give anything they possess.

The country in parts (and especially in the Pangtuma and Bandajuma Districts) is full of excellent iron ore, out of which the natives make-and very skilfully considering the primitive character of their smelting appliances--their spears, knives, and other weapons and rough agricultural implements. The former they polish in a wonderful mamer, and a curious thing in this comnection is that these iron weapons retain their brightness unimpaired quite a long period.

These far up-country tribes do not as a general rule journey themselves or send very much of their produce to the coast, but prefer to exchange it for cattle, wives, and other necessaries to be obtained nearer at hand.

The markets of the interior are a frequent and always interesting sight, and I have often watched these animated and busy scenes. The articles bought and sold there are of every conceivable kind; country eloths, mats, tobacco leaves, iron, palm oil and kernels, rough and clean rice, guinea corn, fruit of all kinds, forls, dried ants, fish, cattle, sheep, goats, 
cotton, skins, etc. As a rule, the women conduct the transactions of buying and selling, and excellent hands at a bargain they are, if rather noisy in their methods. But sometimes the men of Mohammedan type, with Liberians from over the border and other chance visitors from the North-Eastern interior, will take a hand at the chaffering, and the babel of voices speaking, arguing, and assererating becomes positively bewildering. These Mohammedans are very clever workers in leather, and most of the sword-scabbards, leather purses, and sandal-work is done by them. Some of the chiefs of the Susu country, as well as the Fulas, are great cattle-dealers. The beasts are brought principally from that part of the country known as the "Northern Rivers." They come down immense distances to the markets of the coast or to places in the interior near the coast-line. Cattle in these parts are exceedingly cheap according to our standard of prices, a fine bull being frequently obtained for the equivalent of $15 \mathrm{~s}$. or $\mathfrak{E} 1$, while a good cow will fetch, in Sierra Leone,

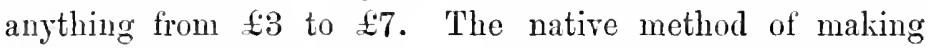
these animals cross rivers or streams is as follows: a rope is first tied round the cow's horns, and she is led to the water edge. Half a dozen native drovers then spring into a dug-out canoe (known locally as a "bullom" canoe), whilst others remain behind and belabour the beast until she enters the water, when, with a chorns of shouts and yells, all follow, the men in the forward part of the canoe paddling for dear life, while those in the stern drag the eow, who begins to swim, following close behind the canoe, after them. I have often seen animals cross in this way, and so skilful are the herders that the job is invariably completed without misliap of any kind. Probably this fact is attributable to the constant practice the native cattle-drovers have in that sort of work, for during the journey down from the " Northern Rivers," or Susu country, many large rivers have to be passed, some of a width of as much as 500 yards across. 
The Susus, Fulas, and natives from the "Nortlem River's" are great traders, and, what is more, remarkably keen lrands at a business deal; and it is these men of Fulani blood who, by coming into the Protectorate and mixing with the bush negro, have assisted so materially to open up the comtry.

Another local industry in which the natives are, in a primitive fashion, great experts is the manufacture of earthenware pottery. They are able to turn ont really artistic bowls and water-coolers, and dishes of clay hardened by a simple process of sun-drying. They have no "potters' wheel," however, and this might be introdnced with advantage. They would be sure to catch on to the idea, and thereby improve their handiwork inmensely. Often in passing through a native town I have come upon rows and rows of pottery, newly made, and put ont into the sun to dry. The articles vary in size from luge calabashes to tiny bowls and jurs, and always I have been struck by the artistic and symmetrical, if plain, cliaracter of the ware. The accompanying photograph shows the native women of Upper Mendiland engaged in this occupation, with their crockery baking nuder the sun's rays.

In a country inhabited by such primitive peoples as is this, any kind of real and permanent advancement, whether moral, political, or economic, must of necessity be a slow business, and one long delayed. But of late years, at all events, neither on political nor commereial grounds can complaint be made that the Car of Progress lias not moved forward fast enough. Rather does it become necessary to panse and review the position soberly, in order to see whether the pace has not indeed been too fast to last. Iet there remains always this fact to be remembered, that if we stand still we are instantly liable to be elbowed aside by our more go-ahead neighbours. Both France and Germany are taking active and energetic measures in the development of their several West African possessions, and are spending huge suns of 


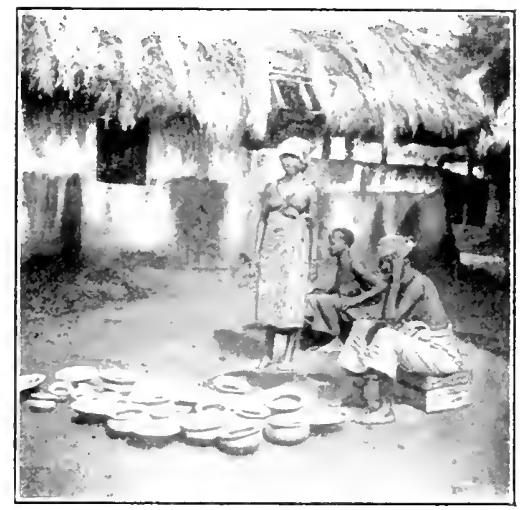

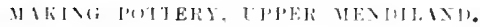

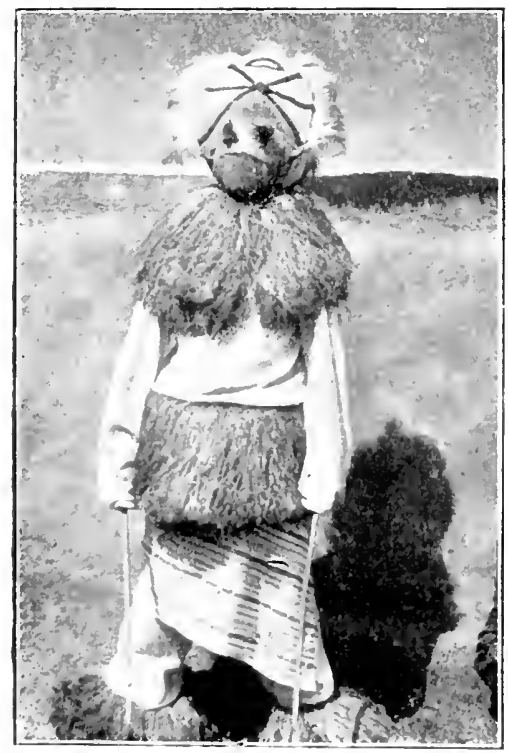

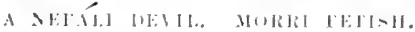

(f). :::it,

To fuite p. 23:? 

money annually on their improvement. It is not possible, therefore, for this country to stand idly by and permit the great natural advantages which our territorial position give us to be used by our rivals for their own benefit. And to prevent this from happening we shall hare all our work cut out. The foreigner is quite smart enough to see the value of the great tracts of territory which he already owns in Africa. And not only is he spending money like water on railways to open these up to trade, but he is actually coming stealthily behind us to glean in our own private reserves. The French Trading Company, established in Sierra Leone, and which has flourishing branches all over the West Coast, as well as at Sherbro and sereral up-comntry towns, has to-day a large proportion of the general trade with Europe. Within the last two or three years Germany has managed to obtain a large portion of the entire ocean-carrying business. So that, unless we look carefully to it, we shall find our commercial stability gradually slipping through on fingers. It behores us, therefore, to put our shoulder to the wheel, and for so long in future as we hold our African possessions, let us make the most of them, commercially as in every other way. There is an old prorerb which says, "Nil sine labore." Let us, in dealing with this problem of West African development, keep that ancient and stinging truism well before our minds. Let us recollect that Great Britain owes her supremacy among the nations, not only to the fact that she is the workshop of the world, but to this other, that she is to-day the greatest commercial power that has ever been knuwn in history. And remembering this, we shall not be in danger of neglecting our duty to every portion of our commercially expanding empire. 


\section{CHAPTER XXI}

FETISII AND SUPERSTITION. SECRET SOCIETIES

"Double, donble, toil and trouble, Fire burn and cauldron bubble."

SHakespeare.

WERE I to attempt anything in the nature of an exhaustive survey of the many and varions secret societies which honeycomb West Africa, a volume twice the size of this would be requisite for that one theme alone. On the other hand, I am conscions that in a work which deals, as does the present, with the African native as he appears in all his native savagery and barbarism, a reference to the rigid, if miwritten, code by which each trifling action in his daily life is ruled and guided, can hardly be omitted altogether. I have therefore resolved to devote a chapter to the subject, although at the most I shall be able to give only a brief summary of a few among the many fetish institutions which exist in the Sierra Leone Hinterland.

For long the secret organisations which flomish in the midst of these primitive peoples have formed a topic of absorbing interest, not alone to anthropologists in this country, but more especially perhaps to those whose lot it has been, as in my own case, to be bronght into intimate personal contact with the Negro in his own land.

As I have already had occasion to observe, the whole of 
this portion of the African continent is steeped to the hilt in fetish. Not an event that happens but is ascribed to this mysterious agency, which has its branches and ramifications alike in the more civilised districts bordering on the coast and in the remote fastnesses of the "bush" in the interior. And in this connection, a fact which has often struck me with some surprise in my dealings with the "edncated" nativethe man who has been in constant contact with Europeans and has come under the direct influence of Christian missionaries and others-is the powerfil hold which these superstitious practices still have over their minds. I have known natives-men in Government employ and holding positions of nore or less responsibility - to be greatly affected by having wittingly or unintentionally transgressed against the fetish code and thereby brought themselves within the range of its power for retaliation. I have in mind the case of a native sergeant, a man somewhat above the average in intelligence, who had received a fair education and even been to England for instruction. This man had no hesitation whatever in ascribing a somewhat serions illness from which he had begun to suffer to neither more nor less a cause than his liaving inadvertently handled a native "medicine."

I ascertained the facts in this case to he as follows :-The man liad becn allotted a house in an up-country village, and in clearing it of an accumulation of rubbish had thrown away a tiny basket, containing leaves and shells, suspended from the roof. He was made aware of his mistake by a village woman, who came over and informed him that he had thrown away the "medicine" of another man, the former occupant of the premises. A few days afterwards, on returning to barracks, this sergeant reported himself sick. On coming before his officer, in reply to a question as to what was the matter with him, he related the story of the basket. At the same time he stated that he did not wish to go into hospital, but would have to seck out a "fetish man" and get the 
medicine "prlled"; for by throwing away that unlucky basket "de medecine done ketch me in the belly."

Now there is not the slightest doubt that that man was sick, although it might have puzzled a medical man to diagnose lis case correctly. But whether his illness was altogether a natural bodily ailment, or whether it had been induced in the first instance by fear of retribution on the part of the "medicine" which he had handled, I am not prepared to say. I shall content myself in this instance by observing that there is hardly a native on the whole coast or in the Hinterland who is not, in greater or less degree, affected by a similar superstition.

The whole pivot on which these strange beliefs turn and hinge is the inflexible credence placed by the native in the spirits, good and bad, which regulate the course of mundane affairs. Consequently, everything in commection with their sarakas (sacrifices) and other offerings has for its object the cncouragement of the good spirits and the propitiation or exorcism of the bad. For the same reason, when a man dies and is buried, his sword, or stick, or other article that he was in the habit of carrying abont with him, is often buried with him, the idea being that he shall not lack a weapon wherewith to fight and overcome such evil spirits as he may encomnter in his journey to Gevarlahun (God's land). In passing by natives' graves in the vicinity of a bush village the observant traveller can hardly fail to notice the number of those that are decorated (?) with bottles, bundles of tied leaves, and other charms-all of them placed there with the one general idea, namely, the invocation of the good spirits and repelling of the bad.

One of the most potent forces in this direction, and a class wielding an enormous influence over the minds of the lower orders in Mendiland, and other parts of the Protectorate, are the Morri-men. This, as I have elsewhere remarked, is a name given locally to itinerating Mohammedan priests who 
wander about this country. Some of these men have come from places so far distant as the Soudan, the Fulani comntry, and other parts of Northern and Nortli-western Africa; and their business is to trade upon the credulity and simplicity of the inhabitants.

"A priest, a thief, and a liar were all hatched ont of the same egg," says an Eastern proverb, and eertainly the Morrimen have done nothing to falsify the sentiment of that uncomplimentary aphorism. The natives seem only too delighted to accept these wandering moolahs at their own valuation, feeding them and paying them handsomely in kind and money for their services in the working of good and evil spells upon their friends or enemies. The more important chiefs, in fact, often retain one in their personal retinue. Of comrse, it is possible that a percentage of these hedge-priests are genuine and conscientious followers of the Prophet; but I shonld say that these are few and far between. The great majority are undoubtedly men of little principle and less religion; at least a fair proportion being natives of the country itself, who lave learnt to read a few verses of the Koran, and who, finding themselves supported by the chiefs as well as the more ignorant of the people, prefer to leave work to their dnpes and to don the white robe and plaited sandals of a moolah.

These Morri-men are, I regret to say, becoming more and more numerous in this Protectorate. I have even known cases of slaves, who have run away from their masters and managed to scrape together a little money, bedecking themselves in the Morri dress and, on this slight capital, setting up in business as fetish magicians. There is no doubt that one of the chief causes which accelerated the deplorable events of 1898 , which I have been deseribing, was the mischief-making of the Morri-men thronghout the entire Hinterland. That the chiefs and people paid large sums of money and made over nuch property to these dangerous impostors is well hinown. And even now, although the sanguinary predic- 
tions of the soi-disant magicians have been utterly falsified in the result, their sinister influence seems to be scarcely anything abated or discounted.

That this influence is, and was, a very real one may be judged when I say that throughout the late rising there was not a single action fonght, hardly a murder committed, or any important movement of the people made, for which the sanction and approval of the Morri-men had not been previously asked and obtained.

Even the common tribesman had recourse to these spurious gentry when he desired a charm to render himself invulnerable, or wanted a talisman to ensure his hammered slug getting "home." I remember taking from the hand of a dead native a gun which on examination proved to be still loaded. The charge was drawn, when I found the bullet to be wrapped in a piece of paper on which Arabic characters had been written, and which I knew to be a Morri-man's charm. I preserved the bit of writing, and some time afterwards had it translated, when it turned out to be an invocation to certain potent spirits that the bullet shonld not miss its mark but shonld kill the white man.

The word "medicine," as well as the name "medicineman," is a terror all over the comtry. Nothing can be begun, nothing done, without it. On every occasion when a white man visits a town or village in the interior and his coming is not expected, a "medicine" is prepared and certain charms made ready, in order that the village and those in it may be protected from a possible malign influence by him or his followers.

Indeed, I am satisfied that in no part of Africa does there exist a more superstitious race than the aboriginal inhabitants of Mendiland. Amongst these people the greater part of my time while in West Africa was spent, and I have had opportunity of becoming rather intimately acquainted with themselves, their mode of life, their tribal customs, and so forth. 
I have the additional advantage of knowing something of their language. Therefore, in giving the following rough outline of the secret societies, I must be understood as referring more especially to those existing in Mendiland, which, again, is by far the largest and most important comntry in the Hinterland of Sierra Leone.

With the adrent of the white man and his cirilising influence, which brings the principles of British justice in its train, the prestige of the national socicties received, as a matter of course, some check. But even to-day they rule to an extraordinary extent, as has been said, the affairs of these primitive peoples.

As regards the precise constitution of these "corporations," although there is room for an infinity of speculation and surmise upon the subject, I have nevertheless reached the mature conclusion that it is altugether impossible for an ontsider ever to become familiar with their carefully guarded secrets. At any rate, I have never met a European, nor do I believe there is a white man living, who has been able to penetrate into the inner arcana of these mysterious associations.

The three most important societies in the country are the Poro, the Yassi, and the Bundn. For membership in the first males only are eligible; to the second men ean be admitted under certain circumstances; while the Bundu, a society of immense importance in the Mendi comntry, belongs exclusively to the women.

There can be no gainsaying the fact that the Poro is a power in the land; for by its code of laws the entire conmunity is bound and governed. The members are practically made freemasons - if the designation mity be employed in a wider sense-and every candidate for initiation has to submit himself to a course of special preparation.

There are two great divisions of the Poro, the religions and the civil. 'T'o the former the boys go, while the eivil arm is established for special purposes, such as the making of war, 
the promulgating of new laws, and so forth. In the Susn comtry there is yet another description of Poro, which goes by the name of simo, but this wonld not seem to have much influenee ontside the boundaries of the Susu tribes.

In order to cement together and combine the varions tribal Poros they are always joined by the chiefs or men in any power. Thus the Society becomes a potent agent for linking the people together, and by and through its ordinances the tribes were formerly entirely, and are still to a great extent, governed. It is really the fear of breaking the Poro laws and of thus calling down the wrath of "fetish" that renders the folk obedient. Although women are not admitted to membership of the Poro, they are nevertheless bound to obey its laws.

At times the Society has been of enormous advantage to the country, as, for instance, when two of the tribes were at war with one another orer some trivial disagreement and a third stepped in with a view to stopping the hostilities. The chiefs would then meet together "in Poro" in orler to pnt an end by liplomatic means to the fighting; and such is the respect in which the Poro is helk, and so great the fear of its "medicine" upon the minds of the people, that the war would cease.

The Poro partakes, at other times, of the nature of a "friendly" society, to membership of which eren infants are temporarily admitted. The ceremony in their case consists merely in carrying them into the Poro "bush" "and out again. The child then becomes a sort of honorary member, and when old enough to join has to go through the usual ceremonies, to be described directly.

There is a Sherbro word- "min"-which means, in Poro, the coming of a spirit from the other world to commune with the people in the Poro. This " min," or spirit, also guards the sanctity of the Poro "tabu." When the "Poro" is placed on a certain fruit or tree an outward and visible sign is attached to this fruit. The "min" is supposed to 
have spoken, saying that this particular fruit shall not be picked, and until this " min," or ontward sign, is removed no one dares to disobey the mandate.

At other times the Poro goes by the name of goila. This in Mendi means "one word," although the Poro goila is "for ever." This idea was bronght into the Mendi country from the Sherbro district about twenty years ago. One of the passwords used in the late rising meant "by your month." These passwords, however, were often local and were continually being changed. They were so carefully guarded, and such strict watch was liept npon them, that it would have been well-nigh impossible for a spy or fugitive to pass through the insurgents' lines. Henee, so few people managed to escape, even when disguised as natives and being able to speak the language.

Here, in the Poro bush, a boy is first cireumeised and afterwards "christened." On his back is imprinted the caste mark of his own order, and he proceeds next to receive instruction in rudimentary botany in its relation to the medicinal properties of various lierbs. It is certain that the knowledge which he gains in this way is no useless acquisition, since the virtues of some of the mative drugs are freely admitted by the European medical confraternity. Eren outside of the Poro, and amongst the highly educated and advaneed natives resident in Sierra Leone itself, great faith is placed, and quite deservedly, in the efficacy of these comtry plants, many of which are still unknown to medical seience; and they are, in fact, far more frequently used by the educated Africans for the treatment of diseases peculiar to this country than European medicine, even when they are able to obtain this latter. Here, as elsewhere, Nature has put ready to the hand of man herbs specially and peculiarly adapted to mitigate the diseases of the country, and in the long lapse of time the inhabitints of these unhealthy regions have learnt in the schoul of expericnce 
how to arail themselves of these means to keep themselres in health.

I have even known serious cases of fever and other sickness to be cured entirely by the use of these home-compounded remedies. Not once, but very many times, have persons in Government employ-soldiers, messengers, clerks, and others -come to me when ill and begred that they should not be sent to the European hospital, but allowed to treat themselves for their complaint in their own way, or, as they called it "country fashion." I have nearly always consented to this; and although at times it seemed as though such people were deliberately going to their death, yet, on the other hand, I have known some remarkable cures to be effected. Personally I am a believer in many of their herbs, and whilst residing in Africa I have myself had recourse to them: such as egbessi root, lemou grass, oogjulubu, somi leaves, and several others.

To retum to the Poro. The Poro can best perhaps be likened to an exclusive club, the revelation of whose secrets would mean either death or, at the very least, complete social and tribal ostracism and excommmication. The Society meets as a rule in the dry season; between the months of October and May. It is at these meetings that arrangements are made for the initiation of new members. The situation of the Society is most usually in the close vicinity of a town with big bush. The entrance of the Poro house is divided into separate apartments by mats, the thick foliage of the forest serving for a roof. This place is called in Mendi, liamehra. A wuju, or messenger, stands just within the entrance to the last of these divisions. This official, as the candidate enters, addresses sereral test-questions to him, which as a rule the neophyte is nuable to answer, although he endeavours perhaps to do so, generally in the affirmative. A pretended struggle now takes place between the Wuju and the candidate for admission, the former making several attempts to drag the 
latter inside, which he at length succeeds in doing. The pastulant is now welcomed by the members present, and the noise of drums and shouting, which has been going on all this time without intermission, ceases.

The next ceremony is the payment of the entrance fee; the Wuju receives his dues, generally a piece of tobacco, a little snuff, or some such thing. Another apartment has now to be "passed" by the candidate, and here the same ceremonial is once more gone through. Further payment is made and the Wuju hands the candidate over to one of the head medicinemen, who asks him which division of the Society he is desirous of joining.

And here I should say that there are three great divisions, or grades, of the Poro: the Kaimahun, which is intended only for chiefs or other very "big men"; the Binima, or Missi, to which the Morri-men usually belong; and the Inyira and Wujanga, whose membership is principally recruited from amongst the slaves, servants, and poor people.

As soon as the candidate has specified the degree to which he aspires, he is mulcted of more fces, and, these having been paid, he next receives some instruction in the Poro laws. But before the real law is demonstrated to him, which completes the initiation, the candidate is sworn to secrecy upon puwerful existing "medicine." He now becomes a full member. After this the Poro "deril" makes his appearance and, with all the newly-elected members, is taken before the people. During this ceremony everybody belonging to the local Poro is supposed to remain inside the club-bouse. In the early morning (the initiation cercmony invariably takes place at night) one of the menibers climbs a tice and arouses everybody by a tremendous shouting. All then come ont, headed by the Wujaugas, who act as a lind of master-of-theceremonies, and licep order. The entire party now procecds into the town, and having walked ronud it and obtained as much as they can from the inhabitants, they return to the bush. 
As a rule the Poro "bush" remains open for about four months in each year, and the ceremony comnected with the initiation of new members is repeated every time a candidate joins.

The Poro "devil," upon entering a town, is accompanied by a large retinue of Poro men and youths, who make as much noise as possible. Prior to his entry, warning is given to everybody to disappear inside their huts and close the doors, while the women must kneel down and shout and clap their hands. But as soon as the "deril" has made his entrance absolute silence is ordained.

The "devil" now commences to speak, which he does through a long tube of hollowed mood. He gives the chief of the place "how d'ye do?" and having asked and received the news, takes his departure.

The longest period when a "devil" remains in a town is that just prior to the ceremony of the youths going out for the first time to the Poro "bush." The queer belief is that during the time preceding this the "devil" is pregnant, and that on the lads coming out of the "bush" in which they have been living during the greater part of the rainy season, the "devil " has given birth to them. If I mistake not, there is a similar superstition prevalent amongst some of the tribes inhabiting the Lower Cougo country.

The dress worn by the Poro boys during their novitiate is most curious. It consists of a kind of twisted rope of leares, which is wound round and round the waist. This girdle very nearly resembles fern, which is indeed one of the emblems of the Poro.

On first emerging from the Poro "bush" the boys have a very good time to make up for their seclusion. For a day they have the free rum of the neighbours' property, and may annex their fowls, sheep, goats, and cattle without any notice being taken of it. But the villagers, aware of this day of grace, generally take precantions beforehand to ensure the 
safety of their property from such incursions. Travellers in the interior will often have noticed long twisted ropes of fern depending from the trees outside a natire town. These are the work of the Poro boys before they leave the bush, and by means of them the Poro "devil" is understood to hare finally ascended to the skies.

Theoretically, of comrse, the head order of the Poro is the chief's grade or division. But in fact the real heads are the Tassos. Every chief with any pretence to importance has his own Tasso-man, who accompanies him to any important ceremony in which he is to take part. These Tassos are arrayed in most weird and fantastic costumes, consisting of human skulls and thigh-bones, feathers, and a sort of net work of fibre which hangs from their waists in the form of a skirt; whilst plates of native iron are attached to their knees and ankles, and clang and jingle as they walk. No woman is ever allowed to so much as look upon the body of a dead Tasso, and when one of them does pay the debt of nature, a "law" is immediately placed upon the town, and all women in it are driven out until the burial has been completed. No one ever dreams of breaking this lex non scripta; if they did, the punishment would doubtless be exceedingly severe. Althongh the Tasso-man is a necessary and important adjunct to all ceremonies, he is, nevertheless, not allowed to dance, himself, on such occasions. All the dancing is performed by individuals known as "Lakas." The belief, in the event of any person who is prohibited by tribal laws from seeing a dead Tasso having succeded in gratifying her curiosity, is that some "medicine will eateh them." To avoid such a fate the guilty party would have to make confession to the Tor-Beuhmor, or " country-fushion man," who would inmediately report the inatter to one of the hearmen of the Poro. In this ease it wonld probably be to the Soko. The culprit is then taken into the Poro "bush," accompanied by the Poro "devil," and after " medicinal " treatment she is admitted into tlıe society. 
She is now considered to be both a man and a woman, and goes henceforward by the name of Marbori, or Debhoi-the latter a Sherbro nord.

The Poro has such a far-reaching power that its tabu can be placed on anytling or everywhere. For instance, "Poro" may, and often is, placed on groups of fruit trees, palms, or anything else which the chiefs may desire to preserve or prohibit from the public or other use. In that case a "Poro medicine," suspended in a conspicuous position, always gires timely warning as to the particular trees on which the talu has been placed.

The placing of this "Poro" upon the natural products of the country has frequently, it goes without saying, the most detrimental effect. For example, the imposition of the reto on the palm-trees of a town, village, or chiefdom entirely prohibits the inhabitants from picking a single nut; for nobody would ever dream of disobeying such an order. Moreover, the ban is sometimes kept for years together on a certain district. The eonsequence is thit over large areas of comntry the palm unts, one of the principal sources of the communal prosperity, and which wonld otherwise have been taken downcountry and sold as produce, are allowed to rot upon the ground. This state of things was, indeed, of such frequent occurrence, and interfered so serionsly with the river trade, that in 1897 the Gorermment was forced to pass a special Ordinance absolutely forbidding the imposition of the tabu on all indigenous products, thereby throwing open the whole country to the industry of the people.

The Morri-men used very often to prepare the Poro "medicine" employed by the chiefs, and always took good care to charge very handsomely for so doing.

The next of the great Societies is the "Society of Spots," known in the Mendi and Sherbro comntries as the "Tassi." This is to a certain extent affiliated to the "Bundu," and, as I have previously remarked, belongs 
primarily to the women, although under certain circumstances Poro men are admitted. So far, also, as I have been able to ascertain, the women belonging to the Yassi society must also belong to the Bumdu, althongh Bundu women need not necessarily be members of the Yassi. The supreme head of this Society is termed the Behlin; the next in anthority goes by the name of the Yaman; and then follow the Kambehs, comprising several different degrees and orders: the Kambeh mama, the liambeh mamsu, the liambeh kehuai, and others.

A regnlation of this Society is that everything comnected with it must be spotted-for example, the sword and drum, stools, knives, \&c., are all splashed with yellow, black, white, or other colour's. The "medicine" house of this Society is usually readily distinguishable by the coloured spots that are painted all over it. But the real raison d'itre of the Yassi Society seems to be the provision of a hospital for such men and women as are able and prepared to pay the fees and who have been, or think they have been, in any way affected by its "medicine" or that of any other fetish.

The mysteries of the "Bundu" are, if possible, more carefully and closely guarded than are even those of the Poro itself. This association, as already stated, admits women only to membership. Its headquarters are always in a remote part of the bush, but, mulike the Poro, their exact location is kept more or less of a secret. Here, the young native girls, on arriving at a certain age, are trained, as in a sort of convent, in feminine dnties and accomplishments. Their education is in charge of an experienced matron or "mammy," who stands towards them somewhat in the relationship of Byron's "Mother of the maids." T'ley are instructed, as are the Poro youths, in the medical use of herbs and in other matter's peculiarly affecting the gentle sex.

As soon as a girl comes into the Bundu she is suljected to certain treatment which has a special significance. The Bundu fetish is admitted by all the natives to be tremendously 
"strong." The Bundu girls are, I ought to add, perfectly free and may walk where they please within the Society's bounds. The law against infringement of any of their rules is extremely stringent, and nobody of the male sex would think of approaching the Bundu lodge or interfering in any way with any of the inmates; for if he did, it would probably mean death. Payments are of course made in this, as in the other Societies, in the form of entrance fees; and any family can send their girls into the Bundn "bush" who are able to contribute the necessary fees.

The photograph annexed will aftord some idea of the peculiar, if somewhat outré dancing dress affected by the Bundu votaries of Terpsichore. At all erents it is but little more abbreriated than the costmme in which the corps de ballet at our theatres are arrayed. In addition, or rather as a completion, to the adornment of the dancers, bracelets of palm-leaf fibre encircle the arms and wrists, while the body-net is made of country-grown and woren cotton. Attached to the knickerbockers are to be noticed a number of small plates of native iron, which make a not mupleasant jingle as the wearers pironette and twirl. The material with which the face of each performer is smeared, and which, hideons as it may appear to our eyes, is but, after all, the African equivalent for ronge, is prepared from animal fat, called in Mendi, wojah.

An infinity of pains and care is expended by the Bundu dancing mistress in teaching her pupils all the mysteries of the dance, which include, of course, a graceful carriage; and the magnificent figures of the young Mendi girls and women are of themselves an ample tribute to the thoroughness of the instruction. Personally, I have been privileged to witness very many of these Bundu dances, and after making due allowance for difference of nationality and taste, I can only say that for grace and rhythmic morement the performance of these dusky maidens is perhaps not far short of that of the coryphees of an Empire or Alhambra ballet. Of course, the 
orchestra available would hardly rank as passable in our sophisticated eyes. Here, the instrument that sets the pace and marks the time is a sehyura, and consists simply of a hollowed gonrd corered with strings, mpon which seeds are threaded which make a sharp metallic click as they are plucked. The other instrument most usually heard at a Bundu dance is a species of wooden drum, called a sanglooi, which is generally manipulated by a man or boy, nsnally the latter.

I have already indicated that at these entertainments a "mixed" andience is permitted to assist. For eren in primitive Wrest Africa the fair sex does not see the force of wasting its sweetness or agility on the desert air alone. The news that a Bundu dance is to be held always, as a matter of fict, brings together a large concourse of spectators, and so highly does the exhibition work upon the feelings of the foll: that at its conelusion numbers of the women rush ont into the centre of the cleared circle and heartily embrace the dancers, an example which I daresay many of the male onlookers would be only too delighted to follow if they were permitted.

The eonchuding ceremony whieh the maidens who have been newly initiated into the mysteries of Bundu have to go throngh on leaving the bush is the "washing." Led by the prineipal niistress of ceremonies, who is called in the Mendi tongue, Mesu, the bery of young leauties march in procession through the town, followed by the admiring gaze of all the men, who, however, are not allowed to take any part on the oceasion. At the conclusion of this " mareh past" the girls proceed to the water-sile, where they are washed with herbs and other medicine. The washing at an end, the party adjonm to the most important barri (courtlouse), where they renain for a further period of from two to four days in charge of the same elderly females. At the end of that time they are at liberty to return to their homes, and their connection with the Bundn is at an end. 
The young women are now supposed to be (and really are) thoroughly rersed in all the things that constitute "accomplishments" in West African bush society, and have a good linowledge besiles of rery many matters which are likely to prore nseful to them in their capacity as the wires and mothers of the tribe in future. It has been said by persons whose lnowledge of Bundu rites is not so great as their curiosity, that practically all the arts a girl learus during her stay in the "bush" are those of allurement and-well, let us say, cocotterie. That is quite a mistaken notion. The Mendi maiden receives an entirely different and much more practical elncation, and if she has, amongst other acquirements, leamit to dance well, that is surely not a matter for blame, but rather for praise. One has only to cast a critical eye romd a London ball-room to observe how very much better it had been had deportment--yes, and dancing-formet a more prominent feature in the school curriculum of the young Englishwoman of to-day.

As in the case of the Poro, the outward and risible sign of the Bundn society is the "devil." Her dress (for she is a feminine demon) is (haracteristic and quaint in the extreme. It is entirely black, and no portion whatever of the wearer's body is permitted to be risihle. From top to toe she is completely corered with clothes, even her very eyes being hidden by a hideons mask of stained wook. The material of which the "deril" dress is composed is thick, fibrous matting, affording something of the appearance of a shaggy robe of matted coir.

On her varions peregrinations the Bundn "deril " is invariably accompanied by a number of attendants, one of whom carries a cireular mat of such a form that when the "devil" sits down she is completely hidden by this, and is thus able to remove her heary headlress without her identity being disclosed. The attendant who carries this mat is termed in Nendi the digla. 


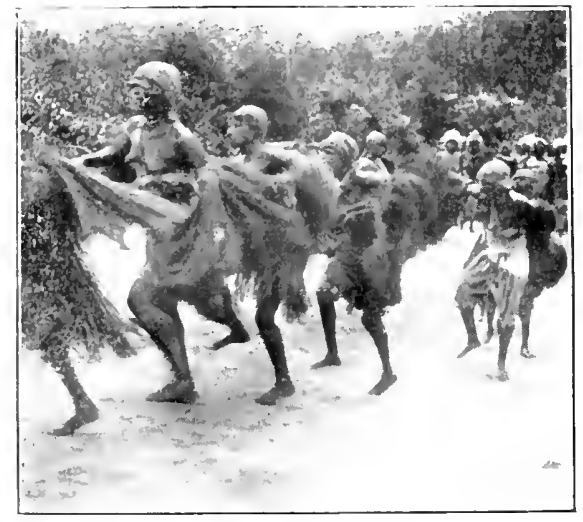

HEXIP GIRL HANATG.

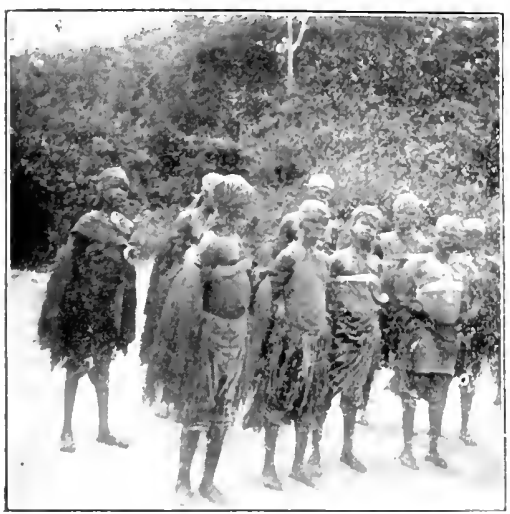

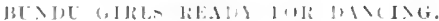

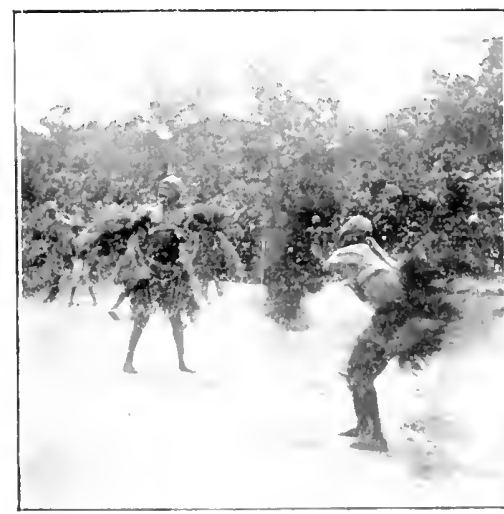

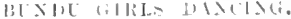



As in the Poro society so in the Bundu, there are three separate degrees or grades of membership. The most exalted is the souceh, a kind of head woman. Then there comes the normah, to which the "devil " belongs, and lastly the digba, or serving grade.

Every town of any pretensions to importance has its own Bundn "devil." In the rare event of any of the Bundn laws with reference to women being transgressed by a man, the "devil" is summoned, and, with her attendants, approaches the offending party. A "pilaver" is then given, in the comse of which the "deril" points with her official staff at the guilty person, and beckons him with signs to follow her into the bush. This he dare not refuse to do, owing to the superstitious fear which is entertained on all hands as to the potency of the "medicine" which the "devil" has at command. The next stage is to report the matter to the headman of the town or village as the case may be, who undertakes to see the offender mulcted in varions fines and penalties for his misdemeanom. If these, again, should not be fortheoming, the man is severely flogged, and in the old days would have stood an execllent chance of being sold into slavery as well. The penalty in the case of a Bundu girl going astray is usually a flogging, but other punishments may be imposed as well.

Amongst the many curions phases of native fetish are the "trials by ordeal," and the natme of the oaths which are taken befure any important ceremony.

During my last residence on the coast, whilst I was touring up-country with His Excellency the Govemor, al native was charged with having aceused one of the carriers of wrongfully selling some of his property. The matter having been hrought to my notice officially, I returned it for investigation to the chief, telling him to find out according to country law whether the num was gnilty or not. The ordeal of the battu (whip) was the test decided upon, and the cerenony was 
carried out in the following way:-The accused is placed in the middle of a ring of interested spectators. The "country fashion man," called in Mendi Tor Tor-behmor, is then introduced, carrying lis "medicine whip" in his hand. He now hands the whip orer to a youth, having first applied some native metion to the lash, and rubbed the lad's arm, hands, and wrists with the juice of certain other plants.

At this stage the boy appears to fall into a sort of hypnotic trance. He rums round the ring, flourishing the whip and making the lash coil in writhing spirals all about the onlookers, though withont tonching anybody. At length the whip appears to have singled ont the culprit, whom it commences to belabour in real earnest amid the cheers of the spectators. The beating goes on, in fact, until the boy is finally called off, and is held down by the "medicine man."

The ordeal of the whip is the final recourse adopted to discover a guilty person. Its decisions are never appealed against, eren by the party most nearly concerned; and the most curions thing about the present case was that the man singled out for the punishment did subsequently confess to his wrongdoing, prior to being homded out of the town.

Another of the native "ordeals" is that in which a pot of palm oil and a hot iron figure. This is nsually applied in the case of women who are suspected of having been unfaithful to their men. The test is conducted as follows: the Torbehmor first rubs over the hands of the suspect a decoction of herbs and leares. A pot is then filled with palm-oil, muder the oil is placed a small iron rod which has been previously made red-hot. The ordeal consists in the suspected woman having to thrust her hand into the oil and pull ont the hot iron. If she is unable to do so without being burnt she is adjudged to be guilty. But if, on the other hand, she suffers no burn, the charge falls to the ground. It is perhaps needless to remark that the proportion convicted in this mode of trial is rather high. 
Besides this test, there is another called the Karu-sortor, in which a kind of magic bowl figures. This has been specially devised for the discovery of petty larceny. The bowl is "dressed "with certain "medicine" and then handed to a little child, nsually a girl, who also has a "medicine" applied to her hands and legs. With the bowl held in her hands she is now told to go and find the guilty party. Like the boy with the whip, the child seems to go off spontaneously into a kind of trance, rushing about from place to place until she finally steps before an individual, who is at once haled before the chief for punishment. This punishment may take the form of a fine, a flogging, or a period spent in the stocks. Formerly the culprit might even have been sold into slavery if the case were a particularly bad one.

Of fetish "medicines" there is an enormous number in the Mendi country, and on one or other of them, or several together, the most solemn and binding oaths are sworn. In the late rising the oath was taken upon no less than seven "medicines." Some of these "medicines " are supposed to be especially powerful, and have such a hold on the minds of the people that it is supposed that they are compelled after swearing on them to speak the truth, the whole truth, and nothing but the truth, whether they are incined to do so or not. Amongst these patent "medicines" are Sarsi, belonging to the Morri fetish-men; Marfanga, Bofimoor (a different one from that used by the members of the Alligator Society, to be described anon), Kaikumba, Tehlang, and many others. When an oath is to be taken the witness stands before the "medicine." This may consist of the incicnt stone laikumba, and on top of it is placed further "medicine," consisting as a rule of red pepper or kola nut. The man then stands up, holding a few twigs from a tree in his hand, and begins the ceremonial by saying in a lond voice, addressing the stone-"My name is so-and-so. I lice at such-and-such a place. I ain a farmer by trate. If 
I lie may the strong 'medicine' that lives inside you cateh me. If I go across the rirer in my canoe may the canoe be upset, and a rocodile seize me. May a poisonous snake bite my foot as I walk alone upon the road, so that $I$ die. May the war come and catch me, and may I and all my family be sold into slarery. If I fail to do my duty may the 'medicine' cuter into my stomach, which will sucll until it bursts." And to the foregoing the Mendis will always add the words 'Nya roteh' (repeated three times) 'cn Gourar,' which is the equivalent to our "So help me, God."

Taken altogrether, the Poro and Bundu are undoubtedly among the most remarkable of all the secret societies at present flourishing in West Africa. That these have, each of them, their distinct use cannot he gainsaid, and probably but for the medical knowledge of the members many a person would fare but badly if ill from wounds or country ferers.

Unhappily there are other organisations amongst the inhabitants which, whilst equally secret in their working, have no redeeming features whatsoever to commend them. The two best lnown-by name at least-are the Human Alligator and Leopard Socicties, and to a short description of these and kindred cults I propose to derote the sncceeding chapter. 


\section{CHAPTER XXII}

\section{SECRET SOCIETIES (continued)}

TTHE long centuries which still separate Europe, with her 1 high state of civilisation and human progress, from Africa and lher crude primeval barbarism, were never more elearly indicated than when, on the advent of the British in the hitherto mknown regions of the interior, a flood of light was first thrown on to the strange and dreadful horrors perpetrated in the name and through the agency of the Human Alligator and Leopard Societies. Their objective and their operation were fiendish and devilish even in a land where deviltry flourished practically mucheeked. No one, whether of high rank or of low, was safe from their bloody machinations. They struck swiftly, stealthily, and in the dark; and always their blow meant-dcath. The best analogy that history furnishes to these terrors is perhaps that of the Vehm Gericht of Gemany in the Niddle Ages, or possibly the Secret Council of Venice. But in both of these instances some semblance, at least, of a trial was rouchisafed to the victim, eren though he had heen pre-condenmed. Here there was none. A man would walk alone by the river bank at crentide. He did not return. Only next day his body, hrutally mangled, was found to tell dumbly of the foul deed that had been perpetrated in the night hours. In very many direetions Great Britain has, through her faithful servants, done splendid and enduring work in Western Africa; 
and in nothing more than by the placing of a sharp check upon these dreadful practices has she deserved the plaudits of humanity at large.

I used the phrase "placed a check" advisedly. It is generally thought that these societies, and others like them, have been absolutely and finally eradicated. I wish that I were in a position to say that this was a fait accompli. Unfortumately, I am afraid that matters are not so well as that. Although their machinations are no longer so openly devised as was the case, say, ten years ago, it is not possible to deny that these odious cults are still existent; as the ghastly details of some crime which, for want of direct evidence for conviction, has to remain unpunished, still occasionally go to sliow.

From their very nature it must be a matter of extreme difficulty, if not of absolute impossibility, to obtain reliable first-hand information about these organisations. The whole of their plans and operations are so secretly hatched and carried out, that even when a crime has been committed and directly traced to the agency of one of the bands, the chance of bringing the murderers to justice is still exceedingly remote. There is scarcely ever sufficient evidence in such cases to hang even a dug by-only a mangled corpse, which, if it could speak, could tell but of a lurking, shapeless form among the reeds, a sudden spring, a knife stab, and-that is all.

So far as I have been able, in the absence of anything like reliable data, to ascertain, the cults of the Human Alligator and the Leopard had their origin between twenty and thirty year's ago. The idea of these was evolved, according to my information, by a few individuals of more or less consequence in the Sherbro and Mendi countries, who put their heads together with the object of devising some means by which certain persons standing in their pathway to power should be got rid of. Obviously, if such persuns were to be put out of 
the way, their removal would have to be aeeomplished in the most secret manner possible. Now, of all the beasts in the West African jungles the leopard is one of the most cunning, most secret, and most deadly in its attack. So that the notion of adopting this skulking animal for a model would suggest itself quite naturally to these plotters. It was resolved, then, that the actual murderers should be disguised as leopards, and the persons selected for the work went into very thorough training for the grnesome part they had to play, learning faithfully to copy the stealthy, eatlike crawl between the trees and bushes which should eulminate at the proper moment in that swift spring upon the msuspecting prey. The part was always "dressed" quite accurately. The head of the slayer and part of his body and legs were covered with a leopard's skin ; he would have provided himself with a vicious-looking knife, having three razor-keen blades of smallest size to simulate a leopard's elaws, and thus armed he would lurk for hours until his victim passed, when lie would scize his opportunity, spring out behind him, and strike him in the back of the neck, the blow generally eansing instant death. The body would then be eut open and eertain portions of it, ineluding some of the fat, abstracted for the purpose of maling strong "medieine." This "medicine" is known to the inner eult of the soeiety as bofimoor, a Sherbro word meaning literally "medicinebag." It is supposed that without this bofimoor the soeiety would be unable to continue with safety its murderous doings. In addition to the horrible ingredients already noted, the eonstituents of this "medieine" include a variety of herbs and other native eoncoctions, all of whieh have a high loeal reputation as heing able to work potent spells. Before these can have any influenee, however, they need to be anointed by the fat of a human body, which must liave been slain in the particular way above deseribed.

The number of people who must, from time to time, have 
fallen victims to these societies would certainly be astounding if the facts were known. For it may readily be imagined what a convenience such an organisation would be to a chief or ambitious headman anxions to get comfortably and quickly rid of a personal enemy or a rival for paramount anthority in his district. A hint, in the form of a substantial bribe, to the reputed heads of this Murder Club, and the thing was as good as done, and their patron's road to " honours" clear before him until, or unless, it chanced that the other side were able to bribe higher still.

The wire-pullers had their own particular method of recruiting to fill the lower ranks. If new members were required to join the society, they were invited to a feast by some of the older hands. Without their knowledge human flesh would be added to the bill of fare. Afterwards, but not until they had partaken, they would be made aware of the fact, and at the same time solemnly warned that unless they joined they would certainly die as a result of having eaten human flesh. In nine cases out of ten the men, although perhaps not personally willing to become professional murderers, would be frightened into joining, when they would at once be put into training for the dreadful part they had to play.

From the original society of the Human Leopard sprang the Human Alligator and Human Baboon societies, which were nothing more or less than off-shoots of the same trunk. These sought ont and killed their victims in a manner equally stealthy, while the method employed had particular reference to the mode of attack of the two animals which the murderers represented for the moment.

In the case of the Alligator the operator was completely covered with an alligator-skin, while his hands were armed with sharp, tearing, iron claws. When out on "business" he would lie perdu among the reeds by the river-bank for hours together, his boly half hidden by the broken shell of an old canoe. Then at the psychological moment he would pounce 
out upon his victim from behind in much the same way as the "leopard." The special sign of their handiwork is the tearing out of the murdered person's stomach.

In January of the present ycar a very bad ease of murder by these Human Alligators was brought before me. Five men were placed in the dock charged under the Protectorate Ordinance with being members of the Alligator Society, and with having in that eapacity been eoncerned in the murder of two matives, a father and son. Both of these persons had been mutilated by having their stomachs torn open, which is part of the modus operandi of the society. The accompanying photo shows these five persons muder escort awaiting their trial.

The "Baboon Society" works on lines almost identical, excepting that the murderers are here disgnised as baboons, from which animals and themselves there is a mighty small dividing-line in point of bestiality.

In 1898, just before the Mendi rising, three men and two children were murdered at Juring on the Sulima Piver in the Galinas country. The circumstances attending the death of these persons were such as to prove beyond all possibility of doubt that they had fallen victims to one or other of these ferocious bands. During the time that I resided in the Protectorate, cases of a similar kind were more than once brought to my official notice.

It must nevertheless be stated that although these "societies" do actually still exist in certain parts of the remote districts, the Colonial Government has accomplished much towards stamping them out. Towards this end an ordinance has been passed, entitled "The Human Leopard and Alligator Society Ordinance," specially designed to deal with such eases; and the elicfs themselves have been both warned and encouraged to leave no stone muturned in the endeavour to hound these misercants to justice. The case which eame before me personally, and to which I have alluded above, was in finct reported in the first instance by 
the paramount chief of the country in which the murders were committed, and the murderers themselres were apprehended by his direct instrumentality.

I have already said that while they are scotched these abominable organisations are not yet entirely killed. Nerertheless it seems certain that in course of time we shall see these murderous bands crushed and dismembered for good and all, and that with the actire assistance of the Gorermment a day may speedily be reached when these loathsome offenders will find the country too hot to hold them any longer. So may it be!

All this is rerr lorrible, of course, and practices such as I hare hinted at abore seem to show that there is but scant difference between the African sarage and the beasts of prey that share with him his matted jungles. Yet, as a thinking people, hare we, I ask myself, any right to reprore the African for exhibiting in regard to the ordinary affairs of life a superstition which, after all, is inborn in all human nature? Let us consiler, in the first place, that whilst we are liring in the twentieth century of progress, these people are still aray back in the second, althongh with hope of adrancement in the years to come. Let us only look back a rery few years, comparatively speaking, in the history of our own enlightened country, and what do we find? The nameless horrors of the Inquisition flourishing abroad and Smithfield ablaze with the martyrs' fires at home. Come nearer still to our own time and we shall find English judges, humane men probably in prirate life, sentencing young children to the gallows for the awful crime of petty larceny!

Eren at the beginning of the nineteenth century, with 223 capital offences recognised by the law, it did not take rery much to hang a man. "If he cut down young trees; if he shot rabbits; if he poached at night; if he stole anything worth five shillings from a person or a shop; if he came back from transportation before his tine." In fact, the chief desire of the Gorernment was to get rid of the criminal 


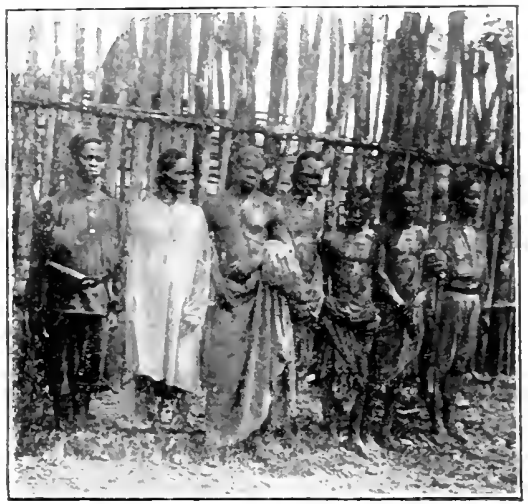

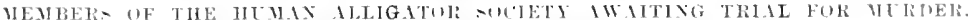

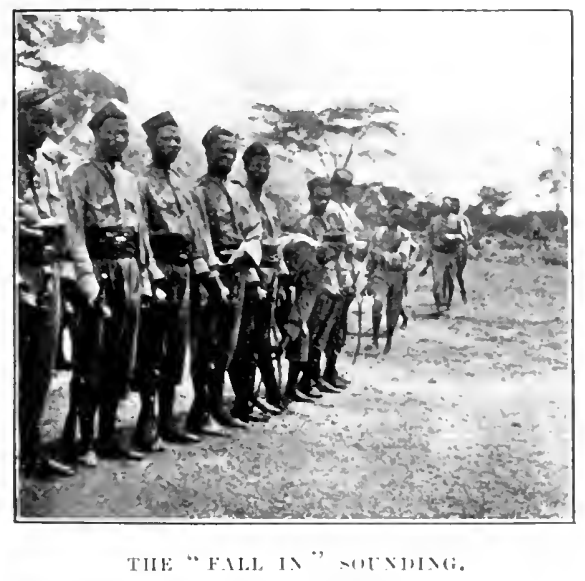

West Afriein Frontier Foree at Drill.

(1?. 2-2:i.) 

classes by hanging them. In looking back even this short time we were indeed in many respects little better than savages. Some of the poorer English children were, in fact, far worse off than African slaves to-day. "They took a child -boy or girl-at six year's of age; they carried the little thing away from the light of heaven, and lowered it deep down into the black and gloomy pit; they placed it behind a door, and ordered it to pull this open to let the trucks come and go, and to keep it shut when they were not passing. The child was set at the door in the dark-at first they gave it a candle, which would burn an hour or two, and then go out. They kept the little creature there for twelve interminable hours." Can we, after this, point the finger of scorn at our African brother? Moreover, before mocking at the naked African doing poojah to his wooden fetish, let us think of the many and bitter differences between ourselves. And finally, before chiding the Black Man for his superstitions rites and observances, let us recollect the rank superstitions prevalent to-day among the most highly educated classes in Great Britain-superstitions which permeate and influenee consciously and unconscionsly the most trivial actions of our daily life. Although to-day we are hundreds of miles ahead of the other in all that goes to make existence worth the living, who is going to speak of finality in this connection? Who is going to say, although under present cireumstances such a thing may seem impossible, that in the next thousand years the Negro may not have ranged up to us, nay, overthrown us from our pedestal of superiority? It is ordained that all mankind must move either backwards or forwards. There can be no standing still. Let us as a nation be thankful for this one thing: that, whilst the process of development must neeessarily be a gradual one, the blessings which follow in the train of civilisation's just laws and stable government are slowly but surely coming to be understood and appreeiated amongst the inhabitants of this outlying portion of our mighty and advaneing Empire. 


\title{
CHAPTER XXIII
}

\author{
HEALTH AND EXERCISE
}

"Health is the rital principle of bliss, And cxcreise of health."

THomson.

\begin{abstract}
A LTHOUGH I have no pretension to the possession of any A medical knowledge, I imagine, nevertheless, that a work having West Africa for its subject would be somewhat incomplete without a reference, however slight, to the ills that flesh, or at all events European flesh, is heir to in this much-abused portion of the globe. I must, therefore, ask any medical man who has taken the trouble to glanee at these pages to pardon the presumption of a mere layman in venturing to trespass upon a province so exclusive. "Qui s'excuse, s'accuse," I know full well, but there is, I believe, another old adage extant to the effect that "fools step in where angels fear to tread," and no doubt the latter aphorism has an application no less apt in the medical than in the general sense. In any event, all I propose to do in this connection is to instance for the benefit of others who may follow certain simple precautions which, if adopted from the beginning, may help to keep the demon of disease at bay. I may just atd that what small lore I have been able to gain on this subject has been acquired in the hard school of experience, during a residence in different quarters of the world.
\end{abstract}


A philosopher has said that a man is either his own doctor at thirty or a fool. At any rate, the trinth of the observation can hardly be denied by the Anglo-African, who is liable at any hour to find himself alone up-country, struggling unaided against the combined assaults of fever, dysentery, and other diseases peculiar to the tropies, while far removed from medical assistance.

Such a flood of light has been thrown of late upon the whole subject of malaria by the grand efforts of Ross, Manson, Meigen, Stephens, and other investigators, that it seems at least possible that this terrible scourge may yet be sucessfully combated, if not entirely stamped out, in the future. It is umnecessary to say that such a desirable consummation would very materially alter the conditions of life for the White Man, not only here, but also in many other insalubrious localities around the British Empire. Indeer, it is questionable if science ever stood the human race in better stead than when she directed the eyes and brains of the medical world upon the probing and investigation of this important subject.

It would be diflicult to over-estimate the importanee which these brilliant discoveries are bound to have, and in fact have had, for those toiling in every eorner of the tropical world. In the past the far-reaching land of Malaria has snatched down into premature graves more of Britain's best and bravest sons than all the bullets of our savage foes have accounted for. The Fever Demon has compelled us to Rouble, aye, often to treble, our executive staff in our West African possessions. It las cansed civilisation and trade alike to stagnate over wide areas; it has retarded the opening up of vast tratets of rich and fertile country; and has cost the Enpire many millions of pounds sterling to hold in even partial elieck. People at home who have never resided in these countries can have but little idea of the power and the tenacity of this deadly serpent, ever waiting an opportunity to fix its fangs into the intruder rash enough to tempt fate ly penetrating 
into its deadly haunts. In England the home-stayer knows malaria only by name-as a bad kind of fever prevalent in tropical countries, and one which occasionally carries off people foolish enough to lay themselves open to attack. That is the vague general impression that obtains. In the tropics the subject is treated with somewhat more respect. In West Africa malaria is recognised as one of the most insidious and tenacious poisons which have ever been injected into the human body. Once bitten by this snake, and if death does not result it will probably take many years before the venom is eradicated -if it ever is so altogether.

At the present day over five millions of human beings die annually in India from fever alone, and a very large portion of these from malaria. Think of it! Orer five million souls - nearly the entire population of London. And there are other countries-West Africa, for instance-where the mortality from this cause is even higher still pro rata to the inhabitants.

Now the responsibility for this has been proved to rest upon the tiny shoulders of the Anopheles mosquito. The most recent research has proved the minute hosts of Anopheles to be themselves the hosts in turn of the malarial parasite. And thus do the winged disturbers of our liard-earned slumbers at once satisfy their taste for human blood and infect, and re-infect, humanity with the deadly germ.

The malarial parasite, which has been classed with the "Protozoa" group, possesses an extremely interesting lifehistory, which it is unnecessary to touch upon in a work of this kind. I may say, lowever, that, once in the human blood, it develops very rapidly within the red corpuscle. It absorbs food, grows, and is capable of reproducing itself.

This reproduction, when once the germ has obtained access to the blood by means of the mosquito, proceeds to spread automatically and without further inoculation by the insect.

There is no doubt that this great discovery will lead, and 
is, in fact, leading, to further research in the inoeulation of disease into man throngh the bite or sting of an insect, and marvellous results and discoveries may be expected in the near futnre as to the cause and reason for infection of certain diseases by this means. With this knowledge shonld follow a new era of things, as far as West Africa and other malarial countries are concerned. Nevertlieless, great matters nove slowly, and so we must not allow the jeers of the sceptic or the derision of the ignorant to trouble us, if the far-leaching results of the great discoveries of our seientists do not show themselves immediately.

The nualarial mosquito theory has been so stremously combated that even now, when the fact of infection by Anopheles-borne Iarasites has been established beyond any possibility of donbt, there remain many persons who, instead of encouraging and assisting those who are nobly treading the intricate paths of science for the benefit of mankind, seem to delight in throwing obstacles in their path, and in endeavouring to show that either the whole theory is erroneous or else that the mosquito is only in a very limited degree responsible for fever in the tropics. I use the word "theory" wrongly, for the malarial mosquito question is not a theory, but a proved and established fact. These scepties have propounded a number of conundrums, nearly all of which have received, if not a conelusive answer, at all events an entirely rational one. They have addnced, for instance, the reputed fiact that in some malaria-ridden places, no mosquitoes exist. Yet many of these places, cited as being mosquito-free, have been foumd to harbour multitudes of them. Others will argne that the theory must be wrong since, althongh they have never been bitten, they have nevertheless suffered severely from malaria. Now, for a person residing within the tropies and in a malarial country, and one conducive to the eonditions neeessary for mosquito life, to assert that he has nerer been bitten is, to say the least of it, somewhat didactie. Some 
persons never feel the bite of a mosquito at all; and it is a well-known fact that those who have been severely bitten for long periods together ccase after a time to feel the irritation caused by the poison entering the wound. Nature, with her wonderful adaptability to local conditions, has provided that the body becomes, so to say, mosquito-proof, at least so far as irritation goes. I have frequently inquired of natives living in mosquito-infested towns how it is that they can bear this pest with impunity, and under conditions which have lept myself and my serrants awake at night. They have invariably informed me that they seldom or never get bitten!

Another argument put forward is that, in certain mosquito districts, malaria does not exist. 'True, in many mosquito districts malaria does not exist. But we are all aware that there are many different tribes of mosruitoes, and that, so far as is at present known, only one of these, and this, happily for mankind, a comparatively rare one, is the efficient host of the malaria bacillus; and that, further, only a very small proportion of the insects themselves are capable of conveying the infection, by having previously fed on an infected body.

It has been noticed that Europeans and other persons engaged in excavating earth and turning up new soil appear to suffer severely from this disease ; and the opponents of the mosquito theory adduce this fact as constituting yet another argument against the mosquito being the transmitting agent. Let us look at this from an unprejudiced point of view. In such excavations as are necessitated by the making of railways and the boring of tumels, a large number of workmen are employed. Burrow-holes and other small displacements of the surface earth are made in the course of working, and in these water is prone to collect, the result being that after a time, larvae are hatched out. In a large body of employés one or two would be certain to be malarially infected, and, once they had been bitten, the spread of disease becomes almost antonatic. 
But let us take the matter further still. At a meeting of the Royal Colonial Institute, held in April, 1900, a most interesting paper on this very subject was read by Sir Patrick Manson, M.D., K.C.M.G., Prineipal Medical Adviser to the Colonial Office, in the course of which a high Colonial official asked, how came the first infected mosquito, since man was stated to be the only sonrce of infection? The answer was, obrionsly, that he was not. On the contrary, there is reason to helieve that many of the lower aninals, some birds and certain monkeys, are probably eapable of harbouring the malarial parasite.

There are, however, one or two points that have not as yet, as far as I am aware, been cleared np. First: is no other insect, such as the sand fly, and the thousands of others that breed and bite in the tropical world, capable of harbouring the malarial parasite or of transmitting it to man? Secondly : are the hundreds of miles of mangrove swamps, with their fetid and putrid mud, that are so monstronsly abundant for mile after mile in the rivers on the low-lyiug West African coast, in any way, other than through the mosquito, capable of extending a malarial atmosphere? Also, can those periodical and widespread epidemics, which from time to time ravage the coast like a plagne and sweep away numbers of the European inhabitants, be traecd to a similar cause? These problems will, no doubt, in time be solved. Meanwhile, the Government and publie, both, should give every encomragement to those lighly deserving bodies, the London and Liverpool Schools of Tropical Medicine, for the splendid and public-spirited efforts they are making to trace these discases to their source and fountain head.

An old Coaster once said to me that the only thing that keeps one alive on the Coast is exereise. This is, of course, an exaggeration; but, at the same tine, there is little doubt that systematic exercise is excecdingly valuable, and is one of the great means for the preservation of health here. I have, 
to be sure, known men who take as little outdoor exercise as possible during their tours, and who yet seem to thrive on it. But they are the exceptions. People are mudonbsedly prone to take too little exercise in West Africa. I have noticed that a great number of the inlabitants of Freetown, eren when going across the road or to their offices, invariably use their hammocks. Indeed, nobody seems able or willing to walk a foot more than is necessary in this country. Such a procedure, even in Emrope, would quite usually result in sickness from want of exercise. The enerrating effects of the climate, the discouragement giren to voluntary locomotion by the bad roads, overgrown hy bush and foliage, and the heat of the sum, all tend to make the European a recluse. Moreover, owing to the present undereloped state of the interior, it is almost impossible for the few Emropean officers stationed up-comtry to play games, snch as tennis, golf, fires, cricket, etc. The making of a temis-court or cricket pitch would be a big undertaking in the bush, where the means of transport are bad, and the residence of Europeans too short to render it worth while for any one or two men to undertake the task.

It is well known how badly men fare in India and other tropical countries who do not go in for some hind of exercise. In India, in her adranced state, nearly ererything is to be obtained in the way of games and sport-polo, cricket, tennis, racquets, rowing, and even football, are to be got at a number of the larger stations. Polo is now being played on the Gold Coast and in Nortlern Nigeria, and other parts, and is a God-send to the sport-loving officer; and this will, no doubt, be the beginning of a further development of British sport and pastimes for the West African "exile."

The man who goes in for systematic exercise in Europe is, as a rule, much fitter than he who does not. In fact, exercise at home is looked upon as essential to every active and energetic Briton. How much more, then, is it needful in the tropies, where a man's liver and uthor organs are apt to get 
out of gear from the strain that is put upon them by climatic influences! But whilst exercise is undonbtedly an essential part of the daily routine, it should be taken judiciously, and if possible, rather as a pleasure than as a duty. Although most things in this way are against a man in the bush, he can always work ont some plan or other, either indoors or out of doors, by which he can obtain the necessary impetus. For instance, he can go in for dumb-bells, and Indian clubs. He can nearly always--at any rate during the dry season-take his gun and go for a tramp in the hush on the look-out for sport. He can bring out a set of gloves and practise the "noble art"; or he can make himself proficient in the use of the singlestick and foils. There are many ways, in fact, by which officers, both civil and military, in the bush, can exercise themselves, and, by so doing, can reap the greatest benefit. Personally, I have found nothing so conducive to the preservation of health as judicions excreise; and it pays one a thousand, nay, ten thousand times, to keep the body fit and in sound condition. I am a great believer in light dumbbell movements, and invariably take one or two pairs out with me. A good spell of these, say, three times a week, followed by a tub, and combined with walking, will keep a man comparatively hard and fit, healthy and strong, wherever he may be.

It is, of course, the duty of every official to use his best endeavours to preserve his health. A man who is continually sick is a sorry servant to his Gorernment; and while in poor condition from the effects of the clinate, or from other causes, he cannot possibly perform his duty with a proper anount of energy and conscientionsness. Military officers, above all, orre it to themselves as soldiers to keep the body strong and in hard condition and in readiness to take the field at a moment's notice and to mudergo the fatignes, privations, ete., which a campaign invariably brings in its train. An officer who cannot stand fatigne as well as his men, and las to give in before they do provided lee is not suffering from illness or 
wounds) is a poor creature, and is looked upon as such by most soldiers, and by none more than by the West African native Tommy. "The first quality in a soldier," says Napoleon in his "Maximes de Guerre," "is manliness in sustaining fatigue and privation-valour comes only second."

But while exercise is of enormous benefit to the bealthy European on the Coast, too much of it has just the reverse effect, and orer-fatigue in West Africa is extremely dangerous. The same thing in Europe is bad enough, but can, as a rule, be put right by a few days' rest. But in West Africa it is different. Here orer-fatigne often has a lasting effect, and may easily be followed by a serious illness. It has been my misfortune to have suffered from this malady on various occasions, and, so far as I am concemed, it has inrariably affected me in the distressing form of sleeplessness.

One of the more serious results is that it is often followed by ferer (as nearly everything else is on the Coast), tending to lower and debilitate the system. Most people who have lived for any lengtl of time in West Africa have malaria germs in their blood, and as suon as their power of resistance becomes lessened by cold, chill, futigue, or the many other calamities which affect the human body, the dormant poison gains the day, overcomes the patient's resisting power, and finally lays him low with a high temperature. A cold bath for those who hare been long resident in the tropics is, as a rule, not adrisable. Personally, I hare found a daily cold bath, following on exercise, to be most beneficial, and I know men who have been for years on the Coast who have never missed their cold tub. But every one knows what suits them best, and of course such persons as suffer from liver, or who are continually having mild attacks of ferer, should not bathe in cold water.

Whenever I come to England after a tour in Africa there are sure to be some people who will ask about the climate. Their questions are generally something like this :- 
"Fearfully bad climate, isn't it? How many men dead in your part? You are lucky to be home again fit and well!"

There is no doubt that the climate is bad enough, and one is combating it from the moment one lands on the Coast up to the day of leaving; and in ninety-nine times out of a hundred a man will carry some bad effect of it away with him. There are, however, simple rules of health, chiefly common sense ones, to be followed when residing in this country. It is adrised by some medical men to take daily a small dose of quinine, while others adrocate a larger dose once or twice a week. Personally, I only take quinine when I feel I need it, and hare been for months withont touching it. I cannot help thinking that the continual daily drugging of oneself with quinine for long periods must have some iujurious effect, either on the nerrous system or digestive organs. Indeed, many medical men are of opinion that large doses of quinine induce blackwater ferer. This theory lias, however, yet to be proved.

On arriving at the Coast it is advisable to take a daily dose of from two to five grains of quinine for the first two months. After that it might be discontinued and only taken when required. A large dose of from fifteen to thirty grains might then be taken once a month.

Everybody should endeavour to arrive in West Africa as fit as possible. A good begriming is half the battle. When there a regular mode of life should be followed. One of the most important precautions to be first taken is, of course, the avoidance of the mosquito. No pains should be spared and no amount of trouble thought too great to outmanœurre this pest. And this can only be done by the careful use of the mosquito curtain and by always wearing mosquito boots at sunset. A favourite place for the mosquito to bite is on the instep, and this he can casily do while his victim is at dinner or sitting about in the evening. Aroid as much as possible going into places where mosquitoes are said to be numerous. 
If, for instance, you intend to sleep at a certain town, and you hear it is infested with mosquitoes, do not go there, but sleep at the next, if possible.

In West Africa one should always assure oneself that one's mosquito curtain contrins no holes and that it is carefully hung. It should never be allowed to hang down on to the floor. If it does, and there are any mosquitoes about, they will assuredly manage to creep underneath the folds. The curtain is invariably hung up in the daytime, and it is then that the mosquitoes will often settle under the bed or in the curtain itself; and careless servants will even enclose the insects in the netting when taking it down. The mosquito curtain should be let dom before sunset, and the bottom of the bed brushed with a duster, and the netting itself well shaken out. It should then be very carefully tucked in all round and not the minutest aperture left through which a mosquito could enter. For these dreadful little pests are very tigers when hunting for their prey, and will hardly be denied. They will buzz for hours round the curtain, examining every nook and crevice, and let there be the slightest hole, no matter how small, they will inevitably find it out and get inside. Then, goodbye to slumber. After all, no very great amount of trouble is entailed daily in taking these most necessary precautions.

I adrocated just now the use of mosquito boots, and this is really an important matter. These boots are made of thin leather and reach nearly up to the knee. They can be purchased rery cheaply at the Canary Islands as a rule, and the money they cost is by no means thrown away. Tro pairs should last, in daily nse, for eighteen months at least. Of course they should not be worn when marching, but simply put on in the evening after sumset. Erery precaution should also be taken to keep one's house spotlessly clean and clear of everything likely to collect water-in which the mosquito delights to lay its eggs. It is a rell-known fact 
that the beginning and end of the rains are the most unhealthy seasons in West Africa. One of the chief eauses of this is undoubtedly the fact that at the commencement of the rains small pools of water will collect. In these the mosquitoes lay their eggs, which are allowed to develop owing to the rain being still insufficient to wash them quite away. The sum's rays do the rest, and out come the mosquitoes. At the end of the rains the same thing happens. There is now not sufficient rain to drown the larva out of the drying pools and moist places. Then the same precautions should be taken to see that all old pails, tin recptacles, and other rubbish capable of holding water are cleared away from one's vicinity. Native servants are very eareless in such matters as a rule and require eontinual watching to ensure that these simple precautions are properly carried out.

If you are travelling in the bush or selecting a site for a camp, keep the latter as far away from a native town as possible and endeavour to have it on rising ground. Also, if you are likely to be stationed yourself for any length of time in the bush, do your best to have the ground on which you will camp devoid of all depressions in which water would be likely to accumulate; all small holes should be filled in and simple drains eut.

When marehing, endeavour to avoid halting in the vicinity of pools. But if you are so unfortunate as to get into a station where these exist, and where consequently mosquitoes abound, spare no pains to drain all ponds and to fill in the puddles also-that is, of course, if you are remaining in the neighbourhood for any time. In this way you may prevent a plague of mosquitoes developing anon.

As I have said before, great care should always be taken while living in West Africa to follow a regular mode of life. Regularity at meals is a great thing to be observed, and a diet of timued "European clop" is to be avoided as far as possible. A lazy cook is a great muisanee. Ot' course he will 
encourage, wherever he can, the use of timned provisions, as these things give him little trouble, either in the way of catering or cooking. Personally, I think the continual use of tinned meat and fish a great mistake at all times in the tropies, or, at least, I maintain that they should only be used to supplement the ordinary rations when one is short of fresh provisions and cannot get anything else. My own idea is that in Africa one shonld live as far as possible on native products, and especially regetables. There are, as I have elsewhere stated, excellent regetables to be obtained in this country, if one knows how to go about it. My opinion is that the system ought, to a certain extent, to be built up on the products of the conntry in which one is residing. In Africa live as far as possible as the Africans live; that is a golden rule to be observed.

Fruit is a most necessary and healthful thing, and may be used with benefit. It should be taken, as a rule, in the early morning before breakfast. It is also better to take two fruits instead of one only-say an orange and a banana, a paupau and an orange, or any other two combinations. The panpan itself is a most excellent fruit, and has the further adrantage of being utilisable when unripe as a vegetable, which indeed it somewhat resembles when cooked. Limes are another firstrate thing, but should not be taken too often as they have a tendency to thin the blood.

Avoid, of all things, taking fermented liquors when the sun is up. Alcoholic stimulants should only be taken in the evening. Whisky and water or soda, and a light claret, are good, but even these only in great moderation. It is injudicious to take liquor on an empty stomach. After illness or when one is fatigued by a long march or hard work, champagne will be found to be most beneficial and exhilarating. There is no better "pick-me-up" at such times than champagne and stout mixed; but this should not be overdone, especially if one is excessively tired. Personally, I have found, after a 
thoroughly hard day's work in the sun, that a cup of warm tea with plenty of milk is the best warder off of the effects of over-exertion.

Early rising is very advisable in the tropics. One should be out and about at the latest by half-past six. There is a coolness and a freshness in the early morning air of Africa that is of great benefit to Europeans, and a deal of mork may be got through at this time. But do not take exercise or go into the sum on an empty stomach. This is a rule which should never be broken under any circumstances whatever. On coming indoors one is usually more or less soaked with perspiration; yet it is a common habit to sit in the verandah or in a hammock and have a "peg" before changing. One would not treat one's polo pony in that way. He is not allowed to stand ont in the cold withont cover, and to drink cold drinks after exercise. The same practice when indulged in by human beings is really most dangerous, and results inevitably in chills and ferer. It only requires a little trouble immediately on coming in to change, rub down, and put on dry clothes. I think one appreciates refreshment much more after first doing this.

Do not as a general thing eat fruit at night, as this is often inclined to cause pains in the stomach. And be careful always to wear a thick cholera belt at night. This is a most efficacious means of fending off chills, covering, as it does, one of the most delicate and rital parts of the body. Colds are one of the most dangerous things in Africa, and the rariations of the climate tend to a great extent to produce them. When on the march, it is a bad plan to be continually drinking water, especially that most poisonous kind of water, swamp-rater. The result will almost certainly be an attack of dysentery. Water should invariably be both boiled and filtered. Here again, do not trust to your native servants to attend to this matter, but see that it is done yoursclf. One of the most useful filters for Africa is the Bcrlifeldt. Take out two kinds 
of this-a "dlip" and a "pump." The latter can be used when travelling as it takes up little room and will draw water in a very short space of time. With this pump-filter should be carried several "candles" and washers. These should be continually changed when dirty, and should be cleaned by means of a brush or a piece of celluloid paper; afterwards being boiled for half an hour and then set in the sun to dry. The "candles" should be changed, and boiled or cleaned, about once a fortnight. The "drip" filter should be kept for the house and treated in the same way as regards cleaning, and recollect that it is desirable to filter one's drinking water first and to boil it afterwards. The boiled water should be carefully deposited and corked up in coolers.

Do not be afraid of fresh air in West Africa, while at the same time avoid chills. It is a good plan to sleep with the windows wide open at night. If one has jalousies fitted in one's house, keep them closed, as plenty of fresh air can get through the slats.

When travelling in the bush, and at any time when going up-country, do not fail to carry certain medicines and medical appliances in your baggage. Excellent portable medicine chests can be obtained from Messrs. Burroughs and Wellcome. If, when up-country, you have an attack of dysentery or something resembling that complaint, talie it in time. Do not allow an unnecessary moment to elapse before treating yourself. A strong dose of castor oil, containing five drops of laudanum, will often prevent, and even cure, an attack of dysentery if talien in gool time. When suffering in this way, the body should be kept very warm by means of a cholera belt or cummerbund.

Another good rule is to avoid umnecessary exposure to the lieat of the midday sun. There is in West Africa such a thing as " sun-ferer," which is a very nasty kind of fever; and there is such a thing as sunstroke. Consequently especial care should be taken when marching in the sum to nse a good 
head-covering. I myself look upon the pith helmet as a rather cumbersome, as well as uncomfortable headgear, and I prefer a soft felt hat, big enough and thick enough to keep off the sun's rays.

Everything in West Africa is damp; and when one's clothes, after having been packed away, are taken out of the box, they will be found quite elammy with moisture, and if left for any length of time, will be apt to become mildewed, owing to the extreme humidity of the climate. It is further adrisable to have one's bed-clothes and wearing apparel placed in the sun for a short time every clay, so as to give them a ehanee to become thoronghly dry. It is best to sleep between blankets; but some men are unable to do this owing to the irvitation produced. But if sheets are used, care should be taken that they are kept perfectly $d r y$; cotton sheets, in particular, are very apt to absorb moisture.

It is just as well to remember, when getting togetlier one's kit for West Africa, that the very best boxes for this country are the small tin air-tiglit ones, and in these all clothes and articles of wearing apparel shonld be kept. Sleep, if possible, in flannel, and always in the evening wear flamnel next to the skin. Carbolic soap will he found to be both exeeedingly refreshing and most cleansing to the skin, and the whole body should be bathed at least once every day and soaped all over. Many persons have complained that the climate has a deleterious effect upon the teeth. This can, to a great extent, be prevented by regnlarly cleaning them the last thing at might before tuming in. It is alvisalile, nevertheless, to have one's teeth properly scen to hefore going ont to the Coast. This precantion will often save a lot of suffering and misery, for dentists are, as a rule, not to be obtained ont there.

As regards the rains, I lave never found that being soaked through even for hours together has had any ill eflect provided one keeps moring all the time. The danger lies, having become wet, in remaining stationary afterwards. Of course, on the first opportunity wet elothes should be changed. 
The imminence of an attack of fever is usually shown by extreme dromsiness, compled with a general feeling of lassitude and yawning. After one has had this very disagreeable experience once or twice, the symptoms can easily be spotter in future. It is advisable not to attempt to struggle against this drowsy feeling, but straightway to swallow a large dose of quinine followed by, say, a tumbler-full of hot water and fresh lime. This precantion will frequently ward off a bad attack.

On the march it often happens that when one's feet are wet throngh they become chafed by the friction of the boots and socks. Never neglect this matter, as a sore in the tropies will often develop into a very bad place and perhaps make you lame and unable to wear a boot for a considerable time. The application of a little zinc ointment will usually prevent a chafe from becoming worse.

If the premonitory symptoms of sunstroke are felt, it is a good plan to inhale cigarette smoke freely, and to bathe the head, neck, and temples in cold water.

To summarise, briefly, the simple rules to be observed, I would say:-Avoid mosquitoes as you would the plagne. Do not expose yourself mmecessarily to the rays of the sum, and at all times wear a good head-corering. Wear a cholerabelt or thick flamnel round the waist at night. Take regular exercise, especially in the early morning hours. Change the clothes immediately after taking exercise. Wear flamel next the skin. Do not worry over trifles; the tendency of life in this part of the world is to make men irritable. Obtain and use fresh vegetables and the other natural products of the country as much as possible. See that your cooking utensils are cleaned every day and laid out by the servants for your inspection-native cooks are apt to be very dirty in such matters. Attend personally to the purity of your drinking: water supply; drink as little as possible when on the march and at all times take alcohol in extreme moderation. Keep in 
mind the rule abont "early to bed and early to rise." See that you are prorided with plenty of oceupation, while remem. bering that over-fatigne in work or play is extremely dangerons. Have yourself vaccinated before going ont to the Coast. When feeling ill always consult a medical man, if possible, and do not fight against an attack of country-ferer. Lastly and comprehensively, $\rightarrow$ observe moderation in all things. 


\title{
CHAPTER XXIV
}

\author{
LUSH FIGHTING
}

"Everything is a matter of opinion in roar."

NAPOLEON.

T $\mathrm{T}$ is a fact incontrovertible that our expansion of Empire 1 has been very largely brought abont by the subjugation of the savage and lawless races who were the original inhabitants of the soil. Looked at from this point of view--the point of view of empire-building, that is to say-the significance and importance of many of our "little wars" can scarcely be over-estimated. And, that being the case, it obrionsly behoves every officer who is serving or is about to serve, in any of these far-nway corners of the earth, to make himself thoronghly master of the local conditions and of the hundred and one other points of a military natme, a complete knowledge of which is absolutely indispensable for the successful prosecution of a campaign there.

Now there is but meagre information to be gleaned on the subject of savage warfare from a perusal of the Infuntry Drill or any of the other official text-books; and that although scarcely a year goes by without a campaign of one kind or another being organised against savages. Thus our officers, often few in number, find themselves in charge of a handful of partly trained native soldiers, and forced to face, not only the 
attacks of an enemy, but the further dangers bred by the pestilential swamps, rank forests, or howling deserts of which parts of Egypt, and East, Central, and West Africa consist.

Moreover, there are varions kinds of savage warfare, the condition and tactics of each being quite distinct, and every one demanding special and careful study. For example, the tactics incidental to a campaign upon the North-west frontier of India would be entirely different from those employed against the fanatical ghazis of the Soudan, or the cunning savages of West Africa, who fight amid, and are protected by, their dense and impenetrable forests. It is upon this mode of warfare that I am desirous of saying something here; and I do so in the hope that the few remarks which I propose to offer may be of some use to officers going out to West Africa, or to those who, being already there, are about to embark on their first eampaign in the bush.

We have, in the past, lost but too many valuable officers and men, not only from the ravages of the climate, but from the shots of a carefnlly concealed enemy, who, as a rnle, fires from the bush at almost point-blank range, and very rarely comes into the open. At present the nature of the comntry, the ravages of the climate, and the peculiar tactics of an enemy who is shadowing your every movement but whom you yourself are not able to see, combine to render a bush campaign one of the most trying and heart-breaking modes of warfare possible. You nerves are kept continually on the stretch, and you probably only realise the propingnity of your foe when he opens fire upon yon at point-blank range.

In recent times most of the fighting in West $A$ frica has been done by native troops and locally raised levies, commanded by British oflicers; and with the exception of the Ashanti Expedition of 1896, no large force of white troops has, at least to my knowledge, been employed here since Lord Wolseley's Expedition to Ashanti in 1874.

These native troops, for the most part recruited and trained 
locally, have, so far, amply justified the confidence that has been placed in them. Their discipline has generally been excellent, and when under fire their bravery, endurance, and dash, have been altogether beyond reproach. The employment of white soldiers in a climate as enervating and unhealthy as that of West Africa is a mistake, and entails on those comnected with the transport an enormons amount of mnecessary tronble and work, as well as costing the nation a great deal more in money. It must be admitted, however, that the moral effect of using white troops against a savage foe is great, and sometimes even a necessity. At the same time, with the splendid native forces we have now at our disposal, we ought to be able to overcome any resistance that is likely to be offered against British arms in that part of the world.

But if European troops be employed, they should consist of carefully picked men, and the best officers should be selected as leaders. Lord Wolseley, writing upon savage warfare, says: "In small wars we must have the best men as leaders. My advice is, select all ranks most carefully for these little wars." And to no country is the truth of this more applicable than to West Africa. One of the great advantages of being able to employ native soldiers-men born and bred in the country-is that we are then enabled, to a great extent, to play the enemy's own game, to follow him into his favourite haunts, and generally to adopt his own strategy and tactics. We have, moreover, the great advantage of superior discipline and arms, and when a savage finds that we are able to strike at him in the same way, strategically and tactically, that he is endeavouring to strike at us, he at once becomes demoralised and meertain how to act. It is then that an attack shonld, whenever possible, be followed up and pressed home. When once a savage foe begins to rum, he will, as a rule, continue to do so, and a panic amongst these people is even more contagious than among civilised troops. A number of the tribes inhabiting West Africa do not, from superstitious motives, 
attack at night. This is so among the Ashantis, who believe that all bad spirits are abroal during the night hours. On the other hand, there are other aboriginal races whose special mode of warfare is carried on during the night. During the operations in Sierra Leone in 1898, most of the attacks were made by the Mendis between the hours of 1 and $5 \mathrm{a.m}$. ; and these people have been particnlarly successful in their night attacks on other tribes. Therefore, when defending a post or station against a savage enemy who are likely to attack at night, great precautions are necessary in order to guard against surprise. Obstacles should be used whenever possible, either natural or artificial. Marshes, rivers, streams, high banks, or precipices make excellent natural obstacles; abattis, consisting of sharp-spiked thorns, wire entanglements, broken bottles, sharp spilies driven into the ground point npwards, and hidden with leaves or loose eirth, and twigs and broken bottles, make good artificial ones. At night, when an attack is pending or about to commence, fire should be withlield as long as possible, as blazing away in the dark without seeing anything does very little good except making a noise; whilst when the enemy find that the shooting is not effective, they will probably be encouraged to attack more vigoronsly. Locally raised native soldiers are apt to fire at inything, and waste an enormons quantity of ammunition nuless kept well in haud. They are naturally highlly excitable and unable to control their leelings, and consequently nearly always fire ligh. It is much better when defending a post in the dark, that soldier's shonld, if possible, lie duwn, protected by any obstacle, either natural or artificial, that is at hand. This in itself' will give a native soldier more confidence, and therefore enable him to make better shooting. Night attaclis are very dangerons and should be aroided whenever possible, especially so as a savage eneny is usmally very well informed as to lis opponent's movements, and with his intimate knowledge of the country is in a much better position to mancenvere at night 
than we are. Like the wild animals of his own forests he is alert, has first-rate sight and hearing, and is cumning and suspicious. If, however, a night attack is to be made on a town, or war canp, and you wish to fall upon it muawares, the utmost precantions must be taken. The march must be made in perfect silence, and by paths that are little frequented. No light of any kind should be allowed. Our West African soldiers, owing to most of them being barefooted, are able to march quite noiselessly. Officers accompanying a colnmn on a night attack should remove their boots, and wear shoes without heels, those having india-rubber or very thin leather or rope soles are the best. Care should be taken to prevent accontrements from knocking together, or cartridges from shaking in the men's pouches.

In marching through the narrow bush paths of West Africa at night, the advanced guard should move very slowly, and the column should be constantly halted. If this is not done, straggling will inevitably occur, and this will entail donbling in the rear to make up the lost ground, and noise will be made. Even if the attacking force is a very small one, this precantion is most necessary, On the other hand, if yon sncceed in catching your enemy mawares by carefully planned tactics, and by rapidly-executed movements, a night attack will have a rery demoralising effect upon him.

We are, as a rule, somewhat inclined I think to muderrate our foe, a mistake that we have paid for dearly on more than one occasion in the past. Nevertheless, it is better to operate with small bodies of troops with a good reserve than with a large unwieldly foree which is more or less bonnd to be confined to the limited area in which its supplies are collected. In taking the offensive against savages, they should, whenever possible, be attacked simultaneously in front and on the flanks, and these attacks should be carried ont with dash and vigour, and by rapidly-executed movements pushed well home. It is rarely that savages will stand for a bayonet charge. 
Small bodies of troops should never be left unsupported, or advance too far into an unknown enemy's comntry. If they do this, they run the risk of being attacked by an overwhelming foree, and completely annihilated. An example of this is afforded by the disaster which lately overtook Colonel Plumkett's column in Somaliland.

Speaking generally, the rules to remember are :-

1. Rather overrate than underrate the enemy.

2. Find the enemy.

3. Bring him to battle.

4. Hare supports and reserve ready to support small detachments.

5. Guard against surprise and treachery.

6. Supply sufficiently strong escorts for lines of communication and food supplies.

7. Ascertain where the enemy obtains his food, and endeavour to destroy his crops, cattle and other supplies.

8. Put little fidith in native reports and guides.

In our West African operations we have, time after time, gone ont of our way to destroy the enemy's towns and villages. This, of course, is necessary, bnt it does not, as a rule, inflict very serious punishment upon him. The West African can live for months in a little grass shelter in the heart of the bush. He can, in fact, exist comfortably in the "dries" without any shelter at all. Moreover, the natives are very quick as a rule in rebuilding their towns. If possible, ascertain from whence they obtain their food. Cattle, sheep, and goats are invariably driven away from the towns and hidden in the bush during hostilities. Large quantities of rice, yams, and other vegetables will also be stored there. If possible, these should be located and destroyed. All rice and other crops should also be destroyed, and even if this is only partially accomplished it will deal the enemy a severe blow, especially if the campaign is likely to be a prolonged one.

One of the truest signs that trouble is impending is the 
absence of all women, children and live stock from the towns. Native troops when going into action should, so far as is possible, be led by their own officers, who know and are known by their men. In several of these operations a host of "special service officers" are sent out, a number of whom know little about the comitry, and still less about the men they are commanding. The West African "Tommy" is an excellent man when properly handled and understood. He is extraordinarily quick in finding out the stuff his officers are made of, and he has, like erery one else, his likes and dislikes, and those in a marked degree. He has a wonderful sense of justice, and the officer who treats his men firmly and kindly, looks after their interests, proves himself capable of sustaining privations and undergoing hardships, and of sharing unselfishly the ricissitudes of a campaign with his men, will be beloved, respected, and followed to the death. In a tight corner this makes all the difference in the world. If the position is serious, and an attack is being made by orerwhelming odds against you, never let the men perceive that anything is wrong. These native soldiers watch every action and every look of their captain - the white man-and would inmediately spot the slightest timidity or hesitation, which might have a grave effect upon their morals. A confident front, a few words of encouragement, a smile, a quick and determined order, will act like a spark and will carry them anywhere, eren to certain death. During the relief of Kumasi, after several hours' severe fighting, and when nearly every officer was lit, and every man tired and hungry, an order was given to the Lagos Hausas to charge and take a stockade with the bayonet in the face of a terrific fire. It was one of those moments, lasting for only the fraction of a second, when the best troops in the world are liable to waver. In this case, seeing the hesitation of the men, a natire officer rushed to the front, and waving his sword above his head, and shouting in his native language to the men to 
follow him in the name of Allah, dashed at the stockade. This action acted like an electrie spark; and enthusiastically shouting their war-cry, the men dashed headlong at the stockade, and drove the enemy out of it.

The number of British officers who periodically go out to West Africa either on special or temporary service witl the local forces, is increasing. But when, upon a young officer arriving on the Coast, who perhaps has never been abroad before, and whose experience of soldiering has probably been confined to the stereotyped manœuvres of Aldershot or Salisbury Plain, he finds himself in command of some small expedition or in charge of a number of soldiers fighting or marehing against a savage tribe, perhaps several days' journey from his station, he is apt to feel bitterly his lack of experience in, and want of, knowledge of the local conditions peculiar to a campaign in West Africa.

It should be recollected also that most of the information obtainable from up-country sourees (that is, as a rule, from friendly natives) is scanty, unreliable, and often quite misleading. It may be necessary to push on with all despateh, either as a relieving force or to punish some refractory tribes who have been amoying their peaceful neighbours by slave raiding, or, as is often the case, stopping the trade from passing throngh their country to the Coast.

Delays in operating against these tribes are dangerous. Strike quickly therefore-and strike home.

One of the first things for an officer to do, if he finds himself in such a position, is to leave no stone unturned until he has obtained as much information as possible from local sources. By local sources, I mean from traders, the Commissioner in charge of the troubled country or district, and from the friendly natives themselves. Often rery valuable information can bo obtained from the merchants and traders (European), who have perhaps resided for a long time in the country, and whose business often takes them into the interior and among the 
natives. If there are such men about, they should be consulted. The local maps should also be carefully comed, though a number of the maps puhlished give but scanty information, a great deal of which again is often far from accurate.

The following points should also be ascertained:-

A. Nature of the comntry.

B. Fighting capacity and probable numbers of the enemy.

C. The kind of weapons used by the enemy and their usual tacties.

D. The name and location of the principal town, and the name of the Paramount Chief, and (if possible) his whereabonts.

E. The sources of the enemy's food supply.

F. The approximate distance to be travelled.

G. The shortest and most favourable route for reaching the objective.

$H$. The cause of the disturbance, and whether it cannot be settled by you or by anyone else before making the attrick.

Having obtained as much information upon all the above subjects as possible, the next thing will be to arrange the transport. This is of the utmost importance. The organisation of the transport for a column in West Africa requires the very greatest care and consideration. In this comtry nearly everything is transported by carriers, each man being able to march from ten to twenty miles a day bearing a load of between 50 and $70 \mathrm{lbs}$. on his hand. Carriers will, as a rule, march at from two to three miles an hour. The loads should be as well balaneed and as compact as possible, and care should be taken, while choosing carriers, to enlist the strongest men. It does not necessarily require a medical officer to do this. Men of medium height and those with short thick necks are usually the best. Carriers of poor physique, or who may be suffering from sickness, give endless trouble when 
forced marches and fatiguing journeys have to be made. The majority of West African carriers are, as a rule, excellent fellows, and very easy to manage when well looked after and properly treated. They are able to do an enormous amount of hard work; and require little food. They will go through the most trying hardships patiently and even heroically, and their uncomfortable position in action, often surroundel by an unseen enemy at close quarters, themselves being unarmed and hampered with a leavy load, can well be imagined. It is not surprising, then, that when under fire, and they see their defenceless comrades being shot down all round them, they sometimes fling down their loads and get ont of hand. Only officers who have had experience in dealing with natives should be selected for transport duty in West Africa; and when the expedition is large this duty is a most trying one.

When a column on the march does not appear to be making sufficient progress the pace should on no account be forcel. This has a very worrying effect npon the carriers, and never pays in the long run. Allow then, as fir as possible, to go their own pace, which they are able to keep up for hours at a stretch. It is the duty of the headmen of squads to spot all laggards, and if they know their business, and have control of their squads, they will soon mend matters. It is, of course, most important that the best headmen possible should be obtained. A bad headman will do more to fatigue and worry his "squad" than heary loads; and in a tight corner, as a rule, he loses control wrer them. The selecting of good headmen will sare an endless amount of trouble during the campaign. As a rule, one headman should be placed over cvery fifteen or twenty carriers, and he should be held responsible for everything connected with his "squad" from the moment they start on the expredition until it terminates. It is as well, if the expedition is going to be a long" one, to make a second or even a third headman of "squads," 
and a reserve for the companies and battalions. They will, of course, take no active part until called upon to do so. This will allow for accidents, casualties, or sickness, which are bound to occur.

The duties of the headmen should be very carefully explained to them, and, in fact, require "drilling" into their heads. Their groups or "squads" should be ordered to obey them implicitly on all occasions. Each headman should know his own set of loads, which, as far as possible, should be kept together. That is, all the rice-bags should be singled ont, and the biscuit and ammunition boxes should each be under different leaders of "squads." Places should also be allotted to these at the end of each day's jommey. Every set of loads should have its own place, and they should on no account be allowed to become mixed. If these precautions are taken much time and confusion will be sared on the early morning start, which often takes place in the dark. If carriers are not well organised, or have not had special loads apportioned to them, they will invariably make for the lightest and most compact load, which causes endless confusion, and often fights among thenselves.

At a signal given, either by the headmen or "captains" of groups or squads, or upon the "fall in" sounding, each carrier should stand by, or sit upon his load, and be ready to pick it up at once and start off on the "advance" or some other signal being given.

In a large expedition, where the carriers number sereral thousands, and where there is likely to be much fighting, the minutest details as regards the transport organisation must be gone into, and everything settled beforehand. Great care and much forethought are therefore necessary if muddle and confusion are to be prevented. A badly organised transport might cause serious trouble to a fighting column, and perhaps end in a disaster, and it behoves every commander to see that things are in working order, and that the transport arrange- 
ments are in good and reliable hands, before embarking upon an expedition of any length or importance in West Africa.

In a large expedition, and where carriers have to be recruited from different parts of the Coast, it is necessary that all the men of one tribe should be kept together. Indeed, the organisation of the earriers should be carried out as far as possible like the organisation of soldiers. Thus, if the number of carriers employed is large they should be told off into battalions, each battalion being, say, 500 strong. If possible, two officers should have charge of each battalion, assisted by from two to four non-commissiuned officers. The battalions shonld then be formed into companies, which, following the military system, would be eight. These should be commanded by a "captain," who, as a rule, would be an intelligent native. 'The companies would be again divided into sections of from ten to twenty men, each under its own headman. A good day's march for men carrying loads is from ten to twenty miles. Supposing, therefore, the adrance depot is some one hundred and five miles from the advance base, and reckoning each stage to be fifteen miles, it wonld be necessary to divide the distance into seven stages. The first battalion could convey five hundred loads in seven days to the advance depot; the sccond battalion conld convey the five hundred loads to the last stage in six days; No. 3 battalion five hundred loads to the fifth stage in five days; No. 4 battalion five hundred loads in four days, until all the loads were deposited along the different stages. It should be so arranged that a number of men conld be sent back withont loads to meet the loads being sent up, and so on.

As soon as all the necessary stores have arrived at the advance depot the columns can push on into the enemy's country. An escort should invariably accompany the carriers from the advance base to the advance depot. Although no enemy is likely to be in the neighbourhuod, an escort is 
invaluable in keeping order, and is a necessity when employing large numbers of carriers.

The daily ration for a native soldier is $1 \frac{1}{2} \mathrm{lb}$. of rice, and each carrier gets $1 \mathrm{lb}$. Rations to Europeans should not be issued oftener than twice a week. It would be better, when possible, to issue rations only once a week, as each carrier is able to take one week's rations with him. European officers and non-commissioned officers, when campaigning in West Africa, should not require more than two, or at the most. three, carriers, one or two of whom would take the kit and bedding, and the other the rations. One carrier is usually allowed for the kits of ten soldiers. Working on these lines, the transport for a force of five hundred soldiers and twenty Europeans for a six days march would be :-

$$
\begin{array}{lllll}
750 \mathrm{lbs} \text {. of rice at } 50 \mathrm{lus} \text {. per load } & \ldots & \ldots & 15 \text { men. } \\
20 \text { Europeans at three carriers each } & \ldots & 60 \text { men. } \\
500 \text { kits at one carrier to every ten } & \ldots & \ldots & 50 \text { men. }
\end{array}
$$

$$
\begin{array}{lllllll}
\text { Total } & \ldots & \ldots & \ldots & \ldots & \ldots & 125 \\
& & &
\end{array}
$$

In addition to the above, carriers would be required for the following :-

150 for the Medical Department.

6 men for each hammock.

Every Maxim gun requires eight men, including ammunition carriers, and each 7 -pounder gun fifteen men, including the carriage, and about the same number for the ammunition.

If a 75-millimetre gun accompanies the colnmn this would entail a further number of thirty-five carriers for gun and carriage, and about forty carriers for ammunition.

\section{Order of March and Nature of Force.}

It is impossible to lay down hard-and-fast rules as to the nature of the force to be employed in a country like West Africa. A great deal will depend upon local circumstances, 
the quality and construction of the enemy's defences, and their character. Artillery is of great valne for demolishing walled towns and certain kinds of stockades. Sometimes, however, the stockades are so well and carefully built that artillery has been found to have rery little effect against them. In the operations in the Karene comtry in sierra Leone, in 1898, 7-pomder gnums had no effect whatever upon the stockades. Nevertheless, the moral effect of artillery fire upon savages is always great. When horses are available, and when the country is of an open nature, monnted infantry are of great serrice. Before this branch of the service is employed, however, it shonld receive special training and be made thoronghly cognisant of the tactics usually adopted by the enemy when momited. Mounted infantry for these expeditions should be trained and recruited locally, and, mnless unaroidable, troops from other parts of the continent should not be requisitioned. In our recent operations in Northern Nigeria and Somaliland the mounted infantry did excellent work.

A few Maxims are a valuable addition to a force in West Africa, though they have the great disadvantage of requiring a large number of carriers for the ammunition. Also, when the bush is very dense (as is nearly always the case) much of the usefulness of the Maxim is lost. 'T'his laandy little gun is, however, of incalculable value for the defence of isolated posts, and for the boat expeditions which so often take place upon the numerons rivers and creeks.

It is important that the loads accompanying a fighting columm be properly distributed and arranged according to their contents. Hanmocks, to the number of 10 per cent., should be in front of the rear guard, and, of course, accompanied by a medical ofticer. In a large force it wonld be necessary to place a few stretchers in rear of the advanced guard. In a snall force articles that are required immediately after arrival should he as far to the front as possible. These would include oflicers' baggage, tents, and stores. The 
best place for artillery is in rear of the adranced gnard. Guns, as a rule, and when sufficient carriers are to hand, are carried in sections; they can, however, be hanled along by means of drag ropes. Owing to the bad conditions of the roads this necessitates constant halts and delays. Taking these guns across meak and insecure native bridges, and through swanps, entails an enormous amount of trouble. Whenever possible, machine guns should be carried in sections. "One of the duties of the adranced guard," say the ofticial text books, "is fighting." This is specially so in West Africa.

The peculiar characteristics of the country cause the head of the narrow columns, as a rule, to come in for the first part and the brunt of the fighting. The advanced gnard should therefore be pushed far enongh ahead, for, as is so often the case when it has to move slowly and cantionsly, the pace of the column in rear is not thereby checked. Preceding the advanced guard would be the sconts, who perform a most difficult and important duty in the bush. Men employed on this duty should be specially trained, and for it soldiers should be employed who hare been bronght up in the bush, and thoronghly understand the nature of the country. The scouts should form a screen to the advanced guard, whose "point" wonld be immediately in rear of it. This point should be furnished by the leading company, near the head of which should be the advanced guard. If the force is a large one, and has guns to spare, a Maxim with escort might, with advantage, immediately follow in rear of the advanced guard. After this would come the main body, which should be rather stronger than the adranced guard. One or two Maxims with escort should march with the main body. The place for the commanding officer shonld be at the head of the main body. In this position he can see what is going on in front (where most of the fighting will probably take place), and can best send orders to the rear. The Commanding Officer should, 
however, interfere as little as possible with the commander of the advanced guard. In action lie would, indeed, be unable to do so.

Modern warfare has shown that the company is the fighting unit. In bush warfare this is not the case. Here the fighting unit is the section. It is well to remember this. It was found in the Karene Expedition of 1898, when some of the most stubborn fighting ever experienced in West Africa took place, that a section was the largest command that could be effectively handled at a time. Colonel G. W. Marshall, who has had considerable experience in West African warfare, and who was commanding for some time in these operations, says in his despatch, "It was found that ten men were quite as many as one command was able to control in the dense bush, and consequently the column was divided into sections of ten."

When a great number of troops are employed, and the carriers run into thousands, the supply column will follow as close to the reargnard of the fighting column as possible. The strength, therefore, would not be so great. The supply column night be divided up as follows:-

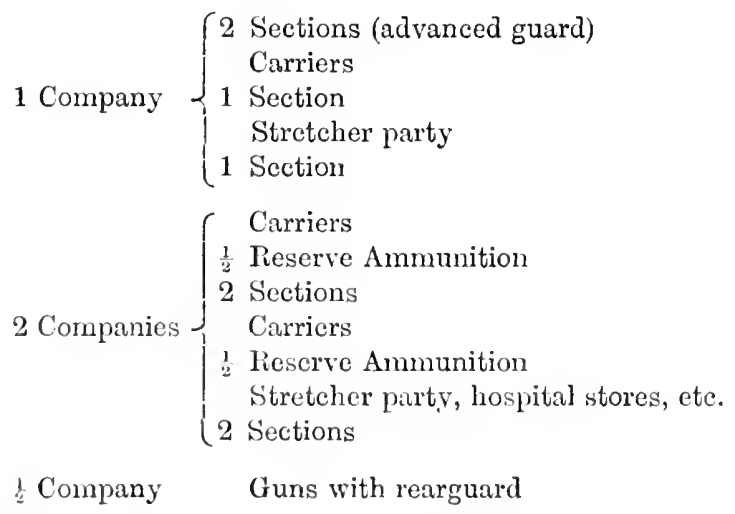

'T'he above depends, of course, upon the number of carriers 
employed, etc. The distribution of troops should be sufficiently strong to act "nn the defensive withnit the assistance of the fighting column.

The halts should he as few as possible. With a large force this tends to disorganise the carriers, worries the headmen, and helps to get the men out of their stride. In making a march of, say, trenty miles, one halt at between ten and eleren miles would be sufficient. At least half the distance should be accomplished before a halt is made. On arriving at the halting-place sentries should be posted, and the positions taken up as nearly as possible according to the order of march, and as it will be resumed. Thus, the adranced gnard shonld ocenpy the front, the main body and rearguard form the flanks, and the supply column the rear. The same order wonld be preserved in camping for the night, and the guns would be properly placed in position. In the event of the halt taking place elnring a march in the enemy's country, the ranks should at once turn outwards to guard against a flank attack. The reargnards of both fighting and supply columns shonld be rery alert, and should ascertain that no soldiers, carriers, or others are left behind. If the halt is of any length, the carriers should be ordered to put down their loads, but should not be permitted to leare them and stray into the bush without special pernission. Sconts should be thrown out, and pushed well into the bush. If attacked during a temporary halt, carriers and men should be ordered to lie flat down and take what corer they can behind the stores and loads. If possible it should be so arranged that the column arrires in camp before nightfall. Darkness comes on very rapidly in the tropics, and much confusion and noise will be saved by getting in before this takes place.

One of the difficulties in West Africa is the enormous length of the columns. This oecurs owing to the narrowness of the paths, which necessitate marching in single file. In the Ashanti Expedition of 1896 the colunn occupied nine 
miles. It requires the utmost skill of the commanders in the rear to prevent gaps and straggling. There are so many obstacles, such as swamps, broken bridges, and felled trees, that a certain amount of distance must be lost. The Commander of the advanced guard should remember this, and after passing an obstacle should "step short" accordingly. If this is not attended to, those in rear will be continually on the double, which will unduly fatigne officers, men, and carriers. Intelligent non-commissioned officers or men should be told off to report immediately when the company in rear is falling too much belind. These men can also be employed in passing along orders, verbal messages, etc.

Officers and other Europeans accompanying the column should endeavour to live as comfortably as circumstances permit. In a climate like West Africa this is a necessity, and if officers and others neglect themselves, it will probably end in sickness, and their services will be lost to the expedition, besides filling up the hammocks and field hospitals. Good food is a necessity. One box (known locally as a "chop" box) should be sufticient for every two or three Emopeans, and should invariably accompany the fighting. column. Recollect that long marches under a tropical sun and on an empty stomach are exceedingly dangerous. Natives of the country can stand it to a certain extent. Enropeans cannot, and are certain to break down. Soldiers and carricrs can carry two days' rice upon their persons, and when possible they should be allowed to do so.

On entering the encmy's comtry, and when he is known to be in the vicinity, three things should be looked out for, viz., stockades, ambushes, and sniping. There are two kinds of stockades, those lying carefully concealed and parallel to the road, and those built at right angles to the road, and known as frontal stockades. The former variety of stockade is sometimes very difficult to locate. Carefully trained native soldiers, musually quick-sighted, will spot these sometimes 
from most trivial indications, such as a broken twig, a footprint, or other equally insignificant mark. The tactics of the enemy are to allow a part of the column to pass the stockade and then to open fire from behind a strongly fortified and loopholed position. The latter stockade is nsually met with at the bend of a roal, close to a stream, bridge, or other obstacle, or at the approach to a village. The enemy's tactics are usnally, when the latter stockade is met with, to endearour to envelope the colnmn.

Sniping is one of the most trying and nerve-breaking of cxperiences. The enemy will be carefully concealed, within five to twenty yards of the road, fire his gun and then bolt, along a narrow path (probably made by himself) into the heart of the forest. His gun is usually filled up with slugs of all shapes and sizes, which scatter a great deal and make very ngly wounds. At so short a range he nearly always sneceeds in hitting some one.

The best way of overcoming the difficulties of stockades and ambushes has been found by experience to lie in the use of "flankers." In some parts of West Africa, howerer, the bush in places is so impenetrable that the progress of flankers is exceedingly slow. Almost every inch of road has to be literilly hacked through. When flankers are employed, every five or six men of each company in the colnmn on the word being given must penetrate into the bush, some twenty to forty yards, and cut a path parallel to the road, proceeding as cantionsly and as quickly as possible. As this is a most trying and fatigning duty the men should be constantly changed. Every man should be carefully trained in these important duties during peace manœurres, and they should be constantly taken into the bush for practice. Whilst a native will follow the bends of the road when inside the bush very cleverly, he can, however, be assisted by some one being told off in the column who will occasionally gire him warning when the paths take a new direction. 
Stockades, when located by the sconts or flankers, should, as already remarked, be taken by an attack directed in front and on the flanks. Thousands of rounds of ammunition and many raluable lives have been lost by the men lying domn and pouring in rifle fire on the front of these stockades, which does very little harm to the enemy. If a 75 -millimetre gun is accompanying the column, this should be directed at the front of the stockade, assisted by Maxim and rifle fire. Two companies should then push forward well into the bush, and endeavour to work round the flanks of the stockade, while a third company should, after allowing sufficient time for the flankers to do their work, fix bayonets and charge. Being attacked rigorously in front, with his flanks seriously threatened or turned, will usually have the effect of driving the enemy from his stronghold.

If possible, the enemy will take advantage of your long column by endeavouring to cut off your advanced or rear gnard, or some other portion of it. He will likewise attempt to envelop you. Protect rourself and your fronts as much as possible by your guns, and decoy your enemy into the bush, which should be penetrated sufficiently on the right and left to prevent hin working round your flanks. He will thus be checked, and should be driven back, when a bayonet charge into his front shonld rout him.

Towns, as a rule, are either stochaded or walled. These should be attacked first by the gums, and the walls breached. The approach to a natire town is usually stubbornly defended, and is nearly always surromded by the bush. Before making the assault on the town the cnemy should he cleared out of the bush on either side. The town should then be rushed, and on entering the men should be extended before advancing. Precaution is necessary in entering a tomn, and every honse should be carcfully searched. In the erent of the town being required for ocenpation it shonld be at once put in a state of defence. If time permits, and the bush or grass is thick 
close to the town, this should be cleared as much as possible. If this is not done it will gire the enemy an opportunity of creeping up in the night and attacking yon. A native town can be quickly put into defence by barricades made of timber, cut trees, transport boxes, ete. Mud walls can be loopholed, and empty bags filled with stunes or sand. Before nightfall every man should be told off to his place, and the others warned as to their places in the event of the "alarm" sounding. It is as well to arm a large proportion of the troops with machètes. These are very useful for clearing obstacles and cutting roads throngh the bush. Pigeons should be utilised for conreying messages, and should invariably accompany a column when going any distance into the interior. When properly trained pigeons are obtainable they will be found to be invaluable, and are the swiftest means of communication after the telegraph wire. They are also a great deal safer than the latter, which takes time and trouble to put up and is always liable to be cut or get damaged.

It is difficult sometimes to know how to dispose of large numbers of prisoners taken by a figliting column. It is well to remember that native troops are often inclined to exercise cruelty when gruarding or looking after prisoners of war left to their tender mercies. As soon after the capture of prisoners as possible they should be brought before an officer, who will inform them, in the presence of their escort, that they need have no fear of being badly treated or tortured, and that their lives will be safe, provided, of course, that they do not attempt to escape, when they should be warned that they will at once be shot.

It is usual, when on the march with prisoners in West Africa, to tie ropes round their waists, which sloould be attached to the escort guarding them. Large numbers can be escorted in this way by squads; the flank men of each squad should be handcuffed. Of course, it would be best to secure every prisoner in this way while marching, but 
this is usually impossible owing to the want of a sufficient number of handcuffs. The utmost precantion should be taken when prisoners have to be guarded in a native town during the night. Honses should be selected which are capable of being easily secured and defended; into each of these a certain number of prisoners should be told off. Sentries guarding them should be relieved every hour, and the ntmost vigilance is necessary, as a prisoner will take advantage of the first opportunity he is given to escape. Shooting should only be resorted to as a final means, or as an example in an attempt to escape. Common humanity demands this.

Every effort shonld be made to allow all Europeans accompanying an expedition in the bush as much comfort as possible, and the best food should be procured for them. In the very small expeditions which may be perhaps, by force of circumstances, unaccompanied by a medical officer, the officer commanding shonld be furnished with the necessary bandages, drugs, and medical conforts; and some one accompanying the columm should have a knowledge of how to render first aid to the wounded. The health of Europeans depends very much upon little things in this country, and it should be remembered that as soon as possible after a long march a change of clothing should be obtained. It is as well to remember also that it is a bad thing both as regards health and example to drink alcohol while on the march during the day. The West African soldier is apt to notice very quickly if his oflicer is taking "liquor" on the march, and the fecling immediately comes into his mind that if his eaptain takes it, why should not he do so. I have myself heard remarks of this kind among the mon, and lide it as mnch as possible, the men get to know quickly enongh, probably through the servant boys, who have the habit of disenssing the merits of their masters among themselves. 
When a column is halted during a march, or for bivouacking, soldiers should not be allowed to stroll away into the bush and eat the roots of immature crops. They are very unwholesome, and often cause much griping of the stomach and even dysentery. Care should be taken also to prevent the men drinking bad swamp water while marching. Many men, while on the march, as soon as water is reached, no matter how dirty it may be, will invariably stop and drink. The less liquid taken during the day the better will the men be able to march, and often the bush swamps are very poisonous.

A knowledge of bush warfare is essential to every military officer serving in these regions. There will probably be a great deal more fighting in West Africa in futmre, for vast tracts of country have still to be explored and the inhabitants taught that we are the paramount power. It is probable also that an increase in our local forces will be necessary in the near future. But we must remember that the taking up arms against the natives is a last resource, and one always to be deplored. Albeit, it has often lad to be done in the past, and will no doult be necessary in the future, in order that civilisation and humanity may each add their quota to THE ADVANCE OF OUR WEST AFRICAN EMPIRE. 


\section{A P PENDICES}

\section{APPENDIX I}

\section{NATIVE LAW IN DISTRICTS WITHIN THE SIERRA LEONE PROTECTORATE}

T most of the natire states within the Protectorate where native 1 law prevails the Court is formed of the King as Paramount Chief and his sub-chiefs and santiggies, or in small towns by the sub-chief and his principal men, who assist in threshing out the matter, and may make remarks on, and offer suggestions concerning the cause, but have no voice in the final decision, the King or Paramount Chief's word being absolute and final.

II. He mas, howerer, delegate his supreme power to some other member of the assembly, who upon this being done exercises the functions belonging to the ling during the inquiry.

III. An appeal may be made from the decision of a sub-chief, but from that of a Paramount Chief there is no appeal, excepting an appeal to arms.

IV. In these Courts crimes of murder, arson, adultery (commonly called women palavers), theft, assault, debt, and other criminal and civil causes, are inquired into, and the decision is generally arrived at after consultation between the King and those of his principal men who sit with him.

V. The punishment meted out for offences differs considerably, in purely pagan countries fines being more generally adopted than any other form of punishment, whilst in districts under Mohammedan influence corporal punishment is adopted in many cases instead of fines. 
The following table gives. succinctly; the punishments adopted in districts under different systems:-

$$
\text { Pagas: }
$$

Murrer.-Penaltr. a heary fine as the price of blood.

Theft.-Flogging. restitution of property or its equiralent, enslare. ment.

Witcheraft.-Buming to death and the confscation of the property of accused.

Rape.-Fines according to position of offender.

Arson.-Rebuilding of house and restitution of equiralent ralue of contents, fine, and. in serious cases. enslarement of offender and family.

Assault.-Fine according to grarity of ofience.

\section{MoH:MMEDAN.}

Murder.-Death.

Thejt-In places where there are no prisons, for first offence Hogging; second, loss of right hand; third, loss of left.

Witcheraft. - Not recognised among strict Wohammedans. Rape.-Death.

Assault.-Fine according to grarity of offence.

Arson.-Flogging, imprisonment. 


\title{
APPENDIX II
}

\author{
NATTE LAW (continuerd)
}

\section{MUSHRIKEEN OR PROEESSING MOHAMMEDANS.}

Murder.-Death or fine, according to the position of the parties and the circumstances of the case.

Theft.-Flogging, restitution of property stolen or its equivalent, enslavement, and for old offenders loss of limb.

Witchcraft.-Enslavement of the accused and all of his family and the confiscation of his property.

Rape.-Fines according to position of offenders, flogging.

Arson.-Same as Pagan.

Assault.-Fine according to gravity of offence.

V. There is no recognised scale of fees, but they are received in kind, in proportion to the position and wealth of the parties concerned, coupled with the importance of the case under inquiry.

VI. The parties opposed to each other in civil causes generally stake a certain amount on the issue, and this amount is given to the party who obtains the judgment of the Court besides any fine that the Court may choose to impose.

VII. It sometimes happens that a fine is imposed on one not able at the time to pay it. Should such person have any friends of influence they sometimes "buy the paliver," or really assume the responsibility of the guilty one.

VIII. Should any one be guilty of a Contempt of Court, or the breach of some local custom, or of insulting any person of intluence, it is custonary to give him Kassi, that is, to fine them, and upon any one being apprised by the Paramount or sub-chief or principal man that he has been so "Iiassied" he has to aclinowledge his offence and pay the fine imposed before any further steps are taken in any cause in which such person may be engaged. 
IX. There is, howerer, always a right of appeal from the decision of a sub-chief to the Palamount Chicf of the country, but the costs attending these appeals generally make them impossible to any one excepting wealthy litigants.

$\mathrm{X}$. In cases where the decision of the Court is not carried out by the party who is giren wrong, that is, against whom an adverse decision has been given, his property, and rery often, if there is not sufficient property, his family; and sometimes himself, are taken to satisfy the judgment giren.

XI. The most frequent palarers which occur in the natire States are "women palavers," really "crim. con." cases, in which the fines are imposed in proportion to the position of the petitioner and the co-respondent, and sometimes results in the enslarement of the offender. The rigid manner in which this law is enforced certainly serves to maintain a purer morality in those States which have had but little contact with the rices of cirilisation. They are, however, sometimes based on rery slender eridence. A husband who has left his harem for some time, on his return questions his wires as to their sereral morements, and if he has any reason to suspect any unfaithfulness, he tries them by the ordeal of putting their hands in boiling oil, and if they are burnt he at once commences to flog them until they mention the name of their suspected paramour, who is pounced upon and made to pay hearily to the injured spouse, excepting he is fortunate enough to prore an alibi, or bring rery conrincing eridence to prove that it was impossible for him to be guilty of the charge.

XII. In cases of witchcraft, or where the accused pleads not guiltr. and the evidence is doubtful, trial by ordeal is adopted, and generally takes the form of drinking the poisonous decoction of the sass wood, putting the hands in hot oil, swearing on the Tillang (a fetish which is supposed to have the effect of disfiguring the nose if ancthing false is uttered after taking an oath on it), and in States professing Mohammedanism, eating the Alafatia balad, which is supposed to result in death to the wrongdoer who dares to eat it.

XIII. Tro of the most important institutions of the Mendi and Yonnie countries in particular are the Porro and Bundu, the former for the men, and the latter for women. They are both of them secret societies, and their members generally meet in the bush, which is called, after the institution that uses it. the Porro or Bundu bush. The approach to it is generally marked by a large clearing, and the exhibition of a good many charms and fetish signs of all descriptions. Each institution is said to be presided over by a deril, and all women have to betake themselves to their houses and keep up a constant clapping of hands at any time when the Porro deril honours a village by a risit. These devils are generally attired in garments made out 
of palm leaves, dyed black, and their heads covered with a mask. None but members of the society are permitted to enter the sacred grove, and it is against their laws for any member of the male sex to enter the Bundu bush, and vice versit. The Porro may be divided into two branches-the general Porro, to which a very large number belong, and at which the rites of circumcision are performed, and the back and chest tatooed with small marks, and the special Porro, which is generally formed for some specific object, and breaks up as soon as that object has been attained. For instance, a Peace Porro, in which several chiefs combine to go and make peace in a disturbed area, under the condition that if their Porro is refused (i.e., their advice not followed) they will form an alliance to fight the parties refusing to follow their advice.

XV. Then again, there is the Porro on palm nuts, which in former years was a law passed by the chiefs and principal men that palm kernels should not be eut before a certain time, so as to prevent the cutting of the nuts before they became ripe, but which has now degenerated into a selfish dog-in-the-manger rule, adopted by some chiefs to prevent others having what he cannot possibly reap himself, as a result of which the nuts are sometimes allowed to fall off the trees and rot.

XVI. If any one dares to pick any nuts, or to reap any land on which a Porro had been placed, he is made to pay a kassi, or fine.

XVII. All fines and payments are calculated by the bar, which ranges from 1s. to $1 \mathrm{~s}$. 6d. in merchandise; head money, which is supposed to be equal to three pounds in merchandise; a ton, equal to four bars; and a Binki, which contains about twenty-five bushels.

XVIII. The rates of exchange for a head of money vary in different parts. In the Timini country, for instance, a head of money would generally consist of twelve pieces of cloth, at $1 \mathrm{~s}$. $6 \mathrm{~d}$. and $2 \mathrm{~s}$. 6d. per piece, $1 \mathrm{keg}$ powder, 1 gun, 4 bar's tobacco, and be probably really worth about $£ 115 \mathrm{~s}$. in Freetown, whilst in some parts of Mendiland ten pieces of cloth, at $1 \mathrm{~s} .6 \mathrm{~d}$. and $2 \mathrm{~s}$. $6 \mathrm{~d}$, , and one cutlass.

In Frectown, worth about $25 \mathrm{~s}$. would be taken as a head of money

In these calculations much depends on the distance of the place where the barter is being made away from the coast as a large allowance has to be made for transport. 


\section{APPENDIX III}

The clauses of the Protectorate Ordinance, 1897, relating to the Hut Tax, are as follows:-

SLIII. From and after the 1st day of January, 1898, every chief, in respect of every house, other than a house owned or occupied by any person not a native, or a person in the service of

House Tax. the Government, situate in any town or village in which he may have jurisdiction, and every person other than a native or a person in the service of the Government, residing in the Protectorate, in respect of every house owned or occupied by him, shall, save as hereinafter provided, be bound to pay to the District Commissioner, or to some person nominated by him, an annual House Tax. And such tax shall be assessed on all houses owned or occupied at any time during the year next preceding that in respect of which such tax is payable.

XLIV. The liability of any person for payment of

Pates of the House Tax shall be computed according to the
Tases. number of rooms in each house, and they shall be taxed as follows:-

(a) For each house with four or more rooms, 10s. per annum;

(b) For each house with three or any less number of rooms, $5 \mathrm{~s}$. per annum.

XLV. The House Tax in respect of each year shall become payable on the 1st day of January of that year, and shall be paid on or after that date, on such day as shall be notified by the Dis-

Tas, when trict Commissioner of each district, or other officer authorised in that behalf by the District Commissioner. Provided always that whenever a chief shall have paid the full amount of House Tax for which he is liable at the time, and in the manner appointed for the payment thereof, the District Commissioner shall allow him a rebate not exceeding 5 per cent. on the amount so paid.

ILVI. The House Tax shall be paid in coin, unless the officer $30 \mathrm{~s}$ 
collecting the same has no alternative but to accept grain, stock, Tax to be paid merchandise, or produee, when the value of such grain, in coin. stock, merehandise, or produce shall be deemed and taken to be the price eurrent at the nearest available market at which such grain, stock, or produce can be disposed of.

XLVII. A receipt in form of Schedule $A$ hereto, or in sueh form as the Governor may approve, for the amount of Receipt. tax paid by each person, signed by the officer receiv. the same. ing the same, shall be delivered to the person paying

XLVIII. If any person or persons liable to pay any taxes, under the provisions of this or any other Ordinanee, shall refuse or neglect to pay the same at the time and in the manner hereinTaxes, before appointed for the payment thereof, the District Recovery of. Commissioner for the timo being is hereby empowered and authorised to levy the taxes on the goods and ehattels of such defaulters. Provided that in the ease of a ehief who is in receipt of a stipend from the Crown, the District Commissioner may, in the first instance, levy the tax on sueh stipend, and, if sueh stipend should prove insuffieient, then on the goods and ehattels of such chief for the balance.

XLIX. All goods and ehattels which shall be levied upon by the Distriet Commissioner shall be sold by him at public auction to the best bidder, and the sum or sums of money arising from Goods levied
on by District such sale the said District Commissioner shall apply to on by District
Commisioners the payment of the taxes imposed by this Ordinance, to be sold. and all charges attending such levy and sale, and shall return the overplus (if any) to the person or persons entitled thereto. * * * * $*$

LXI. The District Commissioner of each district may, from time to time, by writing under his hand, appoint deputies to represent him in the execution of the powers hereinbefore con-

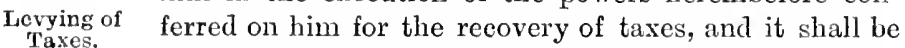
Taxes. lawful for any such deputy to exereise all the powers of the Distriet Commissioner; and all aets done by any sueh deputy in the execntion of his powers shall be as valid and effectual, to all intents and purposes, as if they had been done by the District Commissioner.

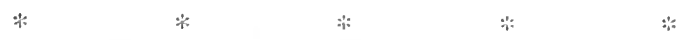

LXIV. It shall be lawful for the Governor to declare, Limits of from time to time, by order, that any district or disTaxation. triets, or any portion or portions of any distriet or distriets, or that any town, village, or house shall be exempt from the 
pagment of House Tax, and to alter, amend, or reroke any such order or orders; and all such orders and alterations, amendments, or revocations thereof, when published in Sierra Leone Royal Gazette, shall have the same force and effect for all purposes as if the same had been made by Ordinance.

$$
\because \quad \because \quad \because \quad \because \% \quad \%
$$

LXXI. Any person who fraudulently evades payment of any Fraudulent House Tax, or Licence Duty, for which he is legally evasion of liable, or any part thereof, shall be guilty of an offence, House Tax, etc. and on proof thereof shall be liable to a fine not ex. ceeding treble the amount of the tax or duty which he ought to have paid. 


\section{APPENDIX IV}

AGREEUENT BETWEEN GREAT BRITAIN AND FRANCE, FIXING THE BOUNDARY BETWEEN THE BRITISH AND FRENCH POSSESSIONS TO THE NORTH AND EAST OF SIERRA LEONE

Signed at Paris, January 21, 1895.

The Special Commissioner's nominated by the Gorermments of Great Britain and France, in accordance with Article V. of the Agree. ment of August 10, 1889, having failed to trace a line of demarcation between the territories of the tro Powers to the north and east of Sierra Leone, in conformity with the general provisions of Article II. of the said Agreement, of its Annex I. and of its Annex II. (Sierra Leone), and with the indications of the Agreement of June 26, 1891, the undersigned plenipotentiaries charged, in execution of the declarations exchanged at London on August 5, 1890, between $\mathrm{Her}$ Britannic Majesty's Gorernment and the Gorernment of the French Republic, to procecd to delimit the respective spheres of interest of the two countries south and west of the Middle and Upper Niger, have agreed to fix the line of demarcation between the above. mentioned territories on the following conditions:-

\section{ARTICLE I.}

The boundary starts from a point on the Atlantic coast, north- Nest of the village of Kiragba, where a circle of 500 metres radius, described from the centre of the village, cuts high-water mark. From this point it proceeds in a north-easterly direction, parallel to the road leading from Kiragba to Robenia (Roubani), which passes by or near the English villages of Fungala, Robant, Mengeti, Mandimo, Momoti. menia, and Kongobutia, at an even distance of 500 metres from the centre of the track, as far as a point half-way between the village of Kongobutia (English) and the village of Digipali (French). From this point it turns to the south-east, and cutting the road at right angles, 
reaches a point 500 metres on the south-eastern side, and proceeds parallel to the road, an even distance of 500 metres, measured as before from the centre of the track, till it reaches a point to the south of the village of Digipali, whence it is drawn directly to the watershed ormed by a ridge which, commencing south of the destroyed village of Passimodia, distinctly marks the line of separation between the basin of the Mellakori (Mellacorée) River, and that of the Great Skarcies or Kolenté River.

The frontier follows this watershed line, leaving to Great Britain the villages of Bogolo (N'Bogoli), Musaliya, Lukoiya (Malagma), Mufuri (Maforé), Tarnenai (Tanéné), Modina (Madina), Obleni, Oboto, Balimir, Massini, and Gambiadi; and to France the villages of Robenia (Roubani), N'Tunga (N'Tugon), Daragli (Daragoué), Kunia, Tombaiya, Heremakuno (Erimaliono), Fransiga (Fonsiga), and Maodea, as far as the point nearest to the source of the Little Mola River ; from this point it follows a straight line to the abore-mentioned source, follows the course of the Little Mola to its junction with the Mola, and then the thalweg of the Mola to its junction with the Great Skarcies or Kolenté.

From this point the frontier follows the right bank of the Great Skarcies (Koler é) as far as a point situated 500 metres south of the spot where the road leading from Wulia (Ouelia) to Wossu (Ouossou), vid Lucenia, touches the right bank. From this point it crosses the river and follows a line drawn to the north of the abore-mentioned road at an even distance of 500 metres, measured from the centre of the track, until it meets a straight line connecting the two points mentioned below, namely :-

1. A point on the Kora. 500 metres above the bend of the river, which is situated about 2,500 metres north of the village of Lucenia, or about five kilom. up the Fora River, measured along the bank, from its point of junction with the Great Skarcies (Kolenté).

2. A gap in the north-western face of the chain of hills lying in the eastern part of Talla, situated about two English miles (3,200 metres) south of the village of Duyunia (Donia).

From this point of intersection it follows the above-mentioned line eastward to the centre of the above-mentioned gap, from whence it is drawn straight to a point on the River Kita, situated above and at a distance of 1,500 metres, as the crow flies, from the centre of the village of Lakhata. It then follows the thalweg of the Fita Piver as far as the confluence of that stream with the Lolo.

From this point of junction it coincides with a line drawn straight to a point on the Little Skarcies of Kaba Piver, four English miles (6,400 metres) south of the tenth parallel of north latitude; and it then follows the thalweg of the Little Skarcies as far as the said 
parallel, which then forms the boundary as far as its intersection with the watershed (ligne de partage des eaux), separating the basin of the Niger, on the one hand, from the basins of the Little Skarcies and other rivers falling westward to the Atlantic Ocean on the other hand.

Finally the frontier follows the aforesaid watershed south-eastward, leaving Falieri to Great Britain and Heremakuna (Erimakono) to France, until its intersection with the parallel of latitude passing through Tembikunda (Tembikounda), that is to say, the source of the Tembiko or Niger.

\section{ARTICLE II.}

The boundary defined in this Agreement is marked on the map which is annexed hereto.

\section{ARTICLE III.}

This Agreement is regarded by the two Gorernments as completing and interpreting Article II. of the Agreement of 10th August, 1889. Annex I. of the said Agreement, Annex II. of the said Agreement (heading Sierra Leone), and the Agreement of 26th June, 1891.

Done at Paris the 21st January, 189j.

(L. S.) E. C. H. Phipfs.

J. A. Crowe.

", Georges Bexort.

, J. HaCsSMaNi. 



\section{INDEX}

A

Acquisition of Sierra Leone, 19

Alldridge, $\mathrm{Mr}$. Commissioner, 26, 128

Anopheles mosquito theory, 261; combatted, 265-66 ; some debatable points on, 267

Apology for trespass, an, 262

Arrival at Bonthe from Kambia, 111

\section{B}

Bandajuma, description of, 31

Bap, a "big medicine" town, 169

Barmah, embarkation at, 165

Batte-kaka, account of Chicf, 190

Behaviour of British troops in campaign, 83

Behaviour of West Indian and Frontier roops, 181 ; Friendlies, 185

Beh Bureh, account of, 50 et seq.

Berri of Bongeh, account of, 36, 98

Birch, Captain C. E., 60

Blakeney's, Major, defence of Panguma, 180

Blonde, H.M.S., details from, 147

Bonthe, description of, 26,27

Boompé Town, description of, 159

Bosworth, death of Colonel, 65

Bourke, Major, operations, 61 et ser

Bulma, description of, 19.5

Bundu Dancing, 248

Bundu Devil, 250

Bundu Punishments, 251

Bundu Society, the, 217

Burial customs in Mendiland, 236

Burnt Ialm-leaf, the, 4

Bush fighting, secunder Fighting, Bush
C

Cimary Islands, description of, 8 et seq.

Cardew's, Sir F., scheme of Government, 206

Cardew, Sir Frederic, 38 et seq.

Carr-Smith's, Captain, operations, 63, 64

Cattle traders, 231

Cave-Brown-Cave, Captain, 171

Cloth, native-woven, 223; need for central market for, 224

Cocoa-nut palm, the, 228

Coffee, cultivation of, on West Coast, 225

Cole, murder of Mr., 136

Collier, murder of Mr., 135

Compton, Captain, R.N., 21

Corbett, Lieutenant, death of, 81

Cotton-growing in West Africa, 220-21

Crossing an Afriean liver, 195-97

Cumningham, Colonel G. G., 146-18

Curreney question, the, 229

\section{$\mathrm{D}$}

Dawkins, Major H. F., 118

Daily Chronicle, report of massacres, 143

Defence of Lambia, 87 et seq.

Defence of Panguma, 180

Distance, native ideas of, 33

Donovan's, Major, operations, 66 et se' 1 ; death of, 71

Eis

Eames, Captrin 'T. B. G., 160

Early treaties, an account of, 203-4 
Elephant country, an, 188

Elephant hunting in Nest Africa, 19394

End of the Rising, the, 187

\section{F}

Fairtlough, Major E. D. H., 173-7479 et seq.

Faunce, Captain, 62

Fetish and superstition, 234 et seq.

Fighting, Bush, Hints on, 280 et seq; uselessness of Infantry Drill in savage warfare, 280 ; difficult nature of, 281; einplosment of native troops adrocated in, 281-82; Lord Wolseley's advice re savage warfare, $2 \$ 2$; conduct of night attacks, 283 ; avoidance of night attacks, 283; precautions against surprise, $2-3$; danger of under-rating the enemy, 284 ; advantage of destroying the enemf's source of supplies, 285; necessity for good officers in, 286; unreliability of native information, 287 ; on obtaining information, 28788 ; hints on transport matters, 28890 ; duties of West African carriers, $289-91$; duties of headmen, 290 ; disposition of troops on the march, 291 ; rations for troops, 292 ; order of march and nature of force, 292 ; artillery for employment in, 293-1; advanced guard, position of, 291 ; supply column, position of, 295 ; halts, 296 ; length of column, 297 ; the food supply in, 297 ; on taking stockades, 298 ; attack on a town, 299-30; prisoners in, 300 ; medical stores, care of, 301

Ferguson, Captain H. de L., 179-84

Fighting near Maketti and Robia, 173-74

Final "medicines," account of, 253

Fodi, 89 ; death of, 101

Forki, Bai's opposition, 79, 80

Freetown, description of , 14, 20

Frontier Force, origin of, 205

Fruit culture in West Africa, 226-28
G

Gegbima, Mendi treachery at, 141

Goodman, Pev. C. H., experience, 137

\section{$\mathrm{H}$}

Health and exercise, $262 \mathrm{ct}$ seq. ; duty of African official to preserve his, 269 ; aroidance of extremes, 270 ; the cold tub, virtues of, 270 ; quininetaking, 271 ; avoidance of mosquitoes, 271-72; regularity of meals, 274 ; moderation in drinking, 274 ; early rising, benefit of, 275 ; water, necessity for pure, 275; water filters, 276; portable medicine-chests, 276 ; sunstroke, how to avoid, 277; damp clothing, never wear, 277 ; best bozes for Africa, 277; fever symptoms, 278 ; sore feet, 27

Herbs, efficiency of native,

Honesty of native police, Sherbro, 121

Hood, Dr. T. 185

House Tax, explanation of, 38 et seq.

Hughes, attempt to rescue Mr., 123; death of, 126-27

Human Alligator, Baboon, and Leopard Societies, 25.5-59

Human Alligator, Baboon. and Leopard Societies Ordinance, 259

Human Alligator, Baboon, and Leopard Societies, English Cruelty (judicial) compared with, 260-61

Humphres, Rev. Mr., murder of, 76 Hutchinson, Captain H. E., 156

\section{I}

Impression of an African forest, 19192

Influence of fetish, 23.5; an instance of, 235

Instigators of the Rising, principal, 118

Iron ore, West African, 230

J

James, Mr., killed at Kambia, 92 
Johnson, death of Colonel, 67

Johnson, murder of Mr., 139-40

Jones's, Sir Alfred, help to West

Africa, 221

Journey up-eountry, a, 29

\section{K}

Kama, massaere at, 142

Kambia, description of, 48-49

Karene, investment of, 61

Katah, account of ehief, 90

King-Harman, Governor, Sir 211

Kirk, Major, 70

Kittam River, description of, 166 ; fighting on, 167; return up, 169-70 Kompa Bai, attempt to arrest, 173

Ewalu, attack on, $175-76$

\section{L}

Labour, native, the question, 222-23

Largo, attack on, 154

Leech's, Mr., experience, 121

Lethargy of Freetown inhabitauts, 208

Lewis, Mr., 135

\section{M}

Major Marescaux's expedition, 176

Malaria fiend, the, 263

Market seenes in West Afriea, 231

Marshall, Colonel, 61 et seq.

Mawfe, massaere of, 131 et seq.

MeDonald, death of Captain, 65

"Medicine," potency of native, 238

Merlicine, the tropical sehools of, 267

Memorial presented to British Government, 201

Missionary work in West $\Lambda$ frica, 20910

Momo-jah, account of, 88-89, 151; co-operates with British foree, 162

Momo-kiki's position, Chief, 15.3

Moore, Captain \$., 173

Morgan, operations by Major, 146 et seq.

Morley, Captain, 70
Mforri-men, influence of, 115, 236-38

Morrison, murder of $\mathrm{Mr} ., 139$

\section{$\mathrm{N}$}

Narrow escape, a, 124

Native propensity for looting, 165, 169

Native smartness in money matters, 230

Norris, Major, 61 et seq.

Northern and Southern Nigeria, a comparison with, 217

o

Oath, a terrible native, 254

Opening up the Kittam, 162 et seq.

Operatious in the Kassi country, 68 et seq.

Operations in the Kemor country, 149

Operations in the Timini country, 73 et seq.

Our Commercial Policy in West Africa, 216 et seq.

Our eommercial rivals, 232

P

Palm kernel industry, the, 219

Pambu, account of Chief, 190

Panguma, investment of, 160 ; relief of, 179

Pepor, camp at, 146

Political administration, onr, 201 et seq.

Poro Soeiety, the, 239 et seq.; passwords, 211 ; initiation ecremunies, 243 ; divisions of the, 243 ; "devil," the, 244 ; tabu, the, 245

Jottery, native, manufacture, 232

l'roteetorate ordinances, the tivo, $206-7$

l'rovinees of Sierra Leone Protectorate, 23

Pujuhun, expedition from, 162

$\mathrm{R}$

Railways, need for, in West Africa, 217-18 
Reasons for holding Kimbia, 97

Pielief of Bandajuma undertaken, 146

Rice, varieties and value of West African, 219-20

Ricketts, death of Lieutenant, 79

Right man in right place, the, 213

Rising in Mendiland, the, 113

Robia, burning of, 175

Robinson, Mr., 96

Rofenka, fighting at, 79

Ronietta, operations in district, 172 et seq.

Rotifunk, massacre at, 140

Pubber industry, the West African, 224

Russell, Captain H. D., 149-59-150

$\mathrm{S}$

Safford, Captain X. E., 159-5̄4

Secret Societies, West African, 239 ct seq.

Sherbro Bai, account of, 114

Sherbro, voyage to, 18

Simera Bai, of IIasimera, 170

Slave question, the, 212

Smallpox at Jimi. 32

Spikes, wooden, as defences, 182

Stansfield's, Major, operations, 61-62

Stealthiness of Mendi attack, 96, 119

Stockades, description of, 83

Symptoms of tribal submission, 185

\section{$\mathbf{T}$}

Tarbet, Major, A. F., 12 ; arriral at

Port Lokko, 59

Tasso men, the, 215

Tiama, expedition, the, 177-78

Timini Rising, the, 59

Trial by ordeal, 251-52

Tyler, Captain, 70-1-8

\section{$\mathrm{V}$}

Value of athletic games, in health, 268

Tandi-Tong, account of Chief, 190

Voyage from Freetown to Sherbro, 2.4 ct scq.

\section{W}

Tar-dance, a ISendi, 163-64

West African natic government, ad.

vantage of, 209

Wilson, murder of Mr., 136

Women Palavers (footnote), 3

Woodgate, General, Sir E. R. P., accompanies Kwalu column, 176

Woodman, Captain J. E. S., 182

\section{$\mathrm{I}$}

Yassi Society, the, 246

Yeld, death of Lieutenant, 63 


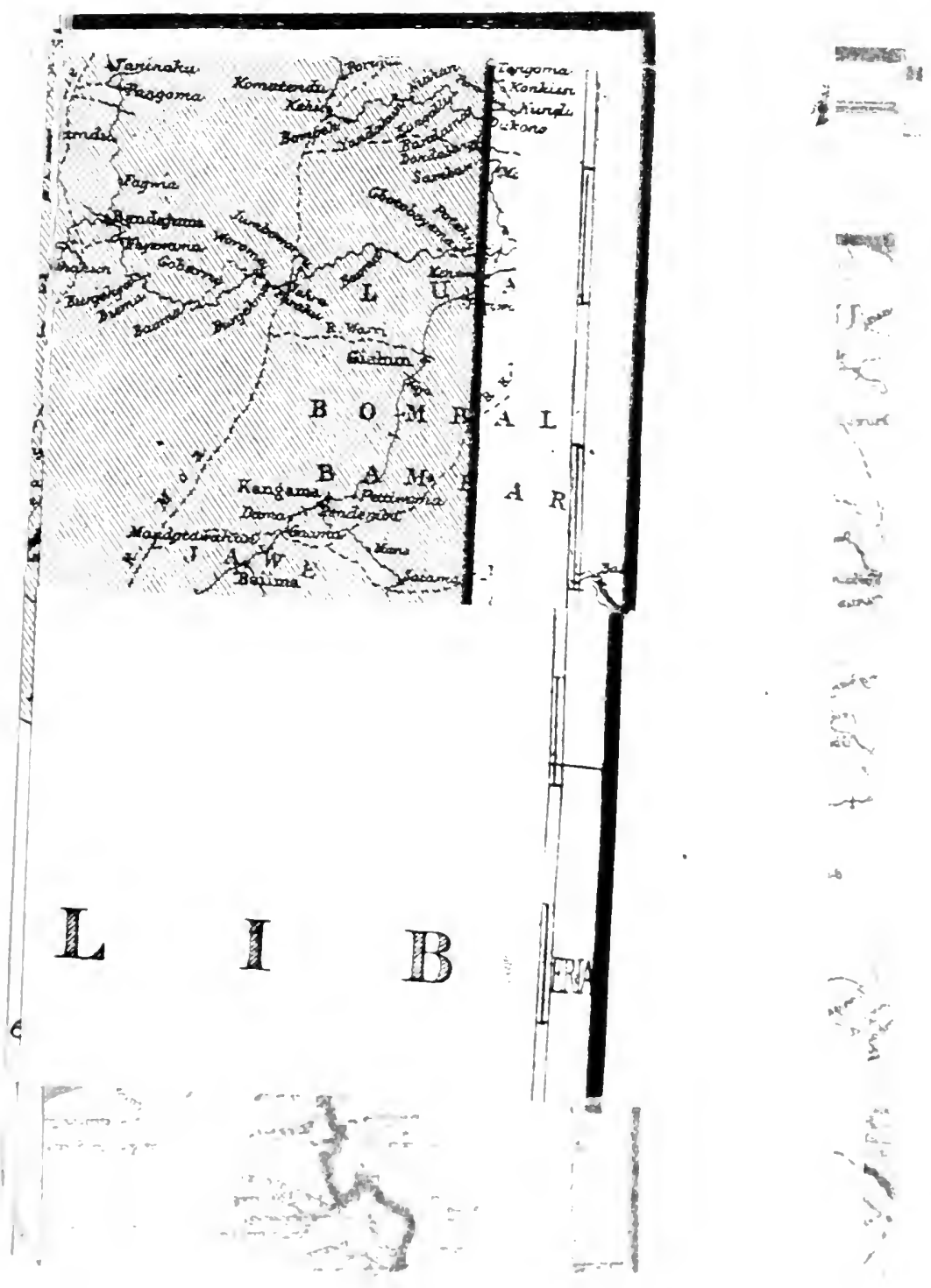




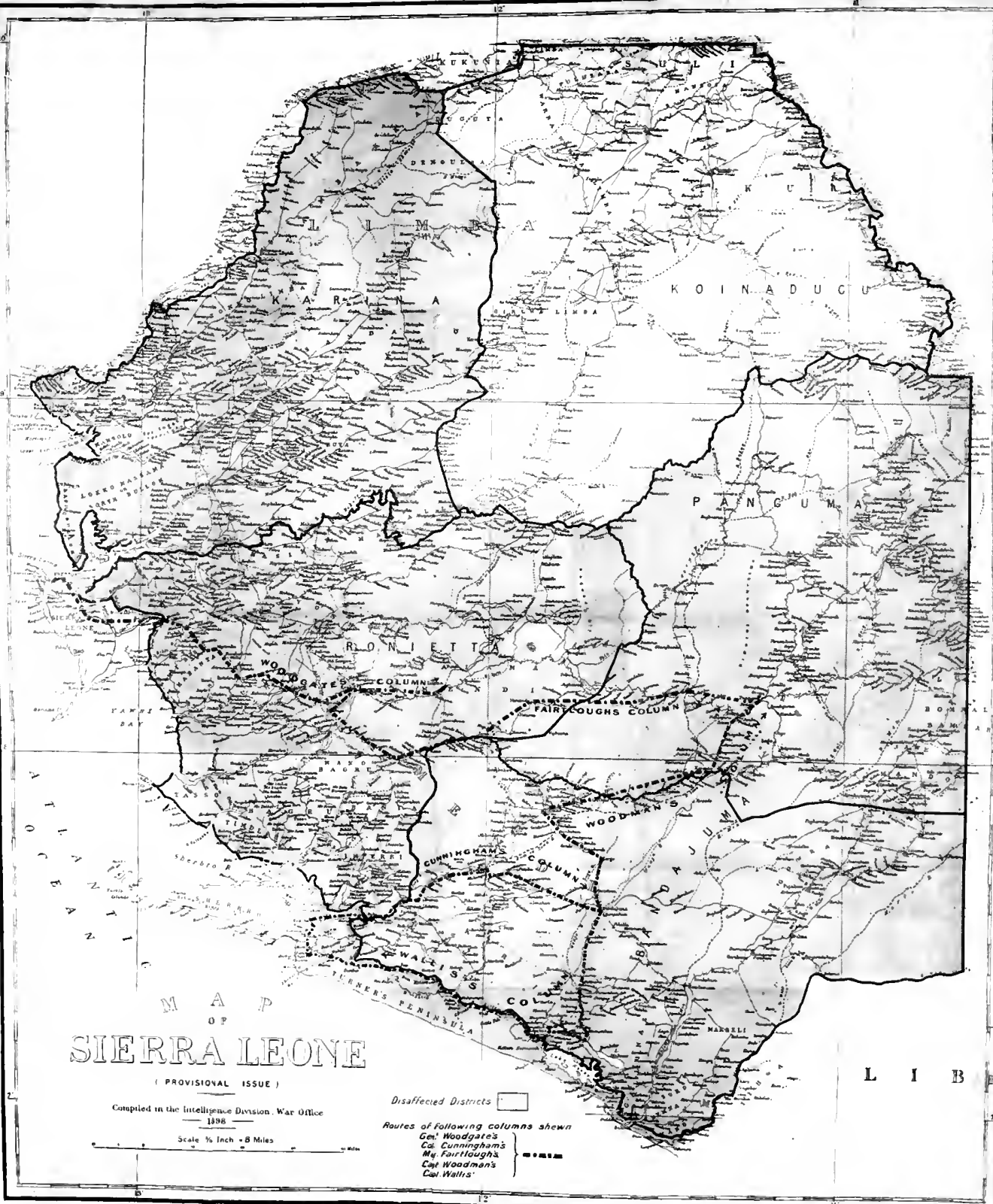


T. FISHER UNWIN, Publisher,

\section{Recent Volumes in the STORY OF THE NATIONS}

A SERIES OF POPULAR HISTORIES.

Each Volume complete with Maps, many Illustrations, and an Index. Large crowen Svo, fancy cloth, gold lettered, or Library Edition, dark cloth, burnished red top, 5s. each. Or may be had in half Pirsian, cloth sides, gilt tops: Price on Afplication.

49. Austria. By Sidney Mhimar.

5o. Modern England before the Reform Bill. By JUSTIN MLCARTHY.

5r. China. With a New Chapter on Recent Events. By I'rof. R. K. Dotglas.

52. Modern England under Queen Yictoria. By JUSTIN MCCARTHY.

53. Modern Spain, 1878-1883. By MArtin A. S. Hume, F.R.Il.S., Author of "Sir Walter Ralegh," \&c.

54. Modern Italy, 1748-1898. By Pietro Orsi, Professor of History in the R. Lice Foscar ini, Venice. With over 40 Illustrations and Maps.

55. Norway. By Professor Halmar H. Boyesen, Anther of "Idylls of Norway."

55. Wales. By OWEN EDwards.

$$
\text { IN PRERARATION. }
$$

The United States of America, 1783-1900. By A. C. Al'Lactihlis. In 2 Volmus.

The Papal Monarchy: From Gregory the Great to buniface V'III. By liev. W. Ijarry.

Mediæyal Rome. By William Mifler.

Buddhist India. By T. W. Rins Davins.

The Story of Greece (to the Romau Occupation). By E. S. SHUCKBURGH.

The Story of Greece (from the Roman Occupation to A.D. 1453). By E. S. SHI.CKHURGit. 


\section{BUILDERS OF GREATER BRITAIN \\ EDTTRD BT \\ H. F. WILSON}

A Sot of 10 Volumes, each with Photogravure Frontisprece, and Map, large crown $8 v 0$. , woth, 5 g. each.

The completion of the Sixtieth year of the Queen's rejgn will be the nocasion of moch retrospect and review, in the course of which the great nen who, onder the auspices of Her Majesty and her predecessors, have heiped to make the British Empire what it Ls to-day, will naturally be bronght to mind. Hence the idea of the present series These biographiea concise but fall, popular bot anthoritative, have been designed with the view of giving ia each case an adequate picture of the builder in relation to his wori.

The series will be under the general editorship of Mr. H. F. Wilson, formerly Fellow of Trinity College, Cambridge, and now private secretary to the Right Hon. J. Chamberlain at the Colonial Oifice. Each volume will be placed in competent hands, and will contain the best portra': obtainable of its subject, and a map showing his special contribution to the Imperial edifice. The first to appear will be a Life of Sir Walter Ralegh, by Major Hume, the leamed anthor of "The Year after the Armada" Others in conterplation will deal with the Cabots, the quarter-centenary of whose sailing from Bristol is has recently been colebrated in that city, as well as in Canada and Newfoundiand; Sir Thomas Maithnd the "King Tom" of the Mediterranean; Rajah Brooke, Sir Stamord Raffles, Lard Clive. Ldward Gibbnn Wakefield. Zachary Macanlay, \&cm \&c.

The Sertes has taken for its moto the Mitonic prayer:-

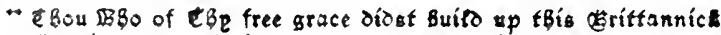
Empire to a glorious ano enbiasle BeigBtb. Bits ail Ber

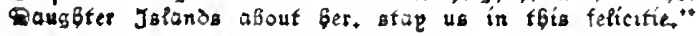

I. SiR WALTER RALEGH. By Martin A. S. Hume, Author of "The Courtships of Queen Elizabeth," \&c.

2. SIR THOMAS MAITLAND; the Mastery of the Mediterranean. BY WALTER FREWEN LORD.

3. JOHN CABOT AND HIS SONS; the Discovery of North America. BY C. RAYMOND BEAZLEY, M.A.

4. EDWARD GIBBON WAKEFIELD; the Colonisation of South Australia and New Zealand. By R. GARNeTt, C.B., L.L.D.

5. LORD CLIVE; the Foundation of British Rule in India. By Sir A. J. ARButhNot, K.C.S.I., C.I.E.

RAJAH BROOKE; the Englishman as Ruler of an Eastern State. By Sir SPENSER ST. Johs, G.C.M.G

ADMIRAL PHILIP; the Founding of New South Wales. By LOUIS BECKE and WALTER JEFFERY.

SIR STAMFORD RAFFLES; England in the Far East. By the Editor.

11. Paternaster Buildings, London, F.C. 


L 0052130762

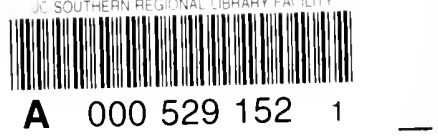


